\title{
Revisão crítica das canções para a voz e piano de Heitor Villa- Lobos \\ publicadas pela Editora Max Eschig
}

\author{
Nahin Marum
}

\section{SciELO Books / SciELO Livros / SciELO Libros}

MARUN, N. Revisão crítica das canções para a voz e piano de Heitor Villas-Lobos: publicadas pela Editora Max Eschig [online]. São Paulo: Editora UNESP; São Paulo: Cultura Acadêmica, 2010. 189 p. ISBN 978-85-7983-110-2. Available from SciELO Books <http://books.scielo.org>.

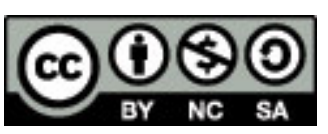

All the contents of this work, except where otherwise noted, is licensed under a Creative Commons Attribution-Non Commercial-ShareAlike 3.0 Unported.

Todo o conteúdo deste trabalho, exceto quando houver ressalva, é publicado sob a licença Creative Commons Atribuição Uso Não Comercial - Partilha nos Mesmos Termos 3.0 Não adaptada.

Todo el contenido de esta obra, excepto donde se indique lo contrario, está bajo licencia de la licencia Creative Commons Reconocimento-NoComercial-CompartirIgual 3.0 Unported. 


\section{REVISÃo CRÍTICA DAS CANÇÕES}

\section{PARA VOZ E PIANO DE}

Heitor Villa-Lobos

\section{PUBLICADAS PELA}

Editora Max Eschig 
CONSELHO EDITORIAL ACADÊMICO

Responsável pela publicação desta obra

Gisela G. P. Nogueira

Lia Vera Tomás

Martha Herr

Nahim Marun Filho 
NAHIM MARUN

REVISÃo CRÍticA DAS CANÇÕES

\section{PARA VOZ E PIANO DE}

HeItor Villa-Lobos PUBLICADAS PELA

Editora Max Eschig 
(C) 2010 Editora UNESP

\section{Cultura Acadêmica}

Praça da Sé, 108

01001-900 - São Paulo - SP

Tel.: (0xx11) 3242-7171

Fax: (0xx11) 3242-7172

www.editoraunesp.com.br

feu@editora.unesp.br

CIP - Brasil. Catalogação na fonte

Sindicato Nacional dos Editores de Livros, RJ

\section{M353r}

Marun, Nahim

Revisão crítica das canções para a voz e piano de Heitor Villas-Lobos: publicadas pela Editora Max Eschig / Nahin Marum. - São Paulo : Cultura Acadêmica, 2010.

144p. : il.

Inclui bibliografia

ISBN 978-85-7983-110-2

1. Villa-Lobos, Heitor, 1887-1959 - Crítica e interpretação. 2. Música vocal - História e crítica. 3. Música para piano - História e crítica. 4. Max Eschig (Editora). I. Título.

11-0115.

CDD: 782

CDU: 78.087 .6

Este livro é publicado pelo Programa de Publicações Digitais da Pró-Reitoria de Pós-Graduação da Universidade Estadual Paulista "Júlio de Mesquita Filho" (UNESP)

Editora afiliada:

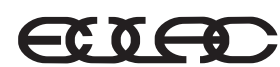

Asociación de Editoriales Universitarias de América Latina y el Caribe

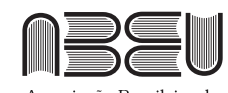

Associação Brasileira de Editoras Universitárias 


\section{Agradecimentos}

Agradeço o apoio financeiro da Fundação de Amparo à Pesquisa do Estado de São Paulo (Fapesp) e o incentivo institucional da Universidade Estadual Paulista (Unesp). Agradeço a assistência dos funcionários do Museu Villa-Lobos, do Rio de Janeiro, e dos funcionários da Biblioteca Nacional da França (BnF Paris).

Foram igualmente importantes para a pesquisa as sugestões dadas pela pianista Sônia Rubinsky.

Meus agradecimentos à professora Danièle Pistone, da Université Paris Sorbonne (Paris IV), por sua fundamental assistência científica e intelectual, por sua dedicação à música de Villa-Lobos e por seu exemplo admirável de amor à arte e à musicologia. 



\section{SUMÁRIO}

Introdução 9

1 Aspectos históricos 19

2 Paradigmas nas canções de Villa-Lobos 25

3 Revisão crítica 33

Conclusão 185

Referências bibliográficas 187 



\section{INTRODUÇÃO}

Esta revisão crítica apresenta uma análise do conjunto de canções de Heitor Villa-Lobos (1887-1959) publicado pela editora Max Eschig, de Paris. As trinta canções publicadas formam um painel importante do estilo vocal e pianístico do compositor, pontuando praticamente toda a sua vida criativa. O trabalho respeitou a ordem cronológica da criação das coleções: de 1919 a 1946. Além das trinta canções publicadas, incluíram-se no livro as três canções não publicadas que fazem parte da série Canções típicas brasileiras. Tais obras estão depositadas nos arquivos do Museu Villa-Lobos no Rio de Janeiro.

Nesses 27 anos de produção percebe-se uma das principais tendências estéticas desenvolvidas pelo compositor brasileiro: uma fusão de estilos musicais diversos inspirados em cantos indígenas, melodias afro-brasileiras, temas do interior do Brasil, canções populares urbanas e na música erudita europeia, que provocaram observações como as de Anais Fléchet sobre Villa-Lobos (2004, p.11): "um cruzamento de escolas europeias com os ritmos africanos e melodias indígenas". Por sua multiplicidade estilística e grande abrangência cronológica, apontamos vários paradigmas nessas canções que poderão contribuir para a compreensão das obras e do estilo musical de Heitor Villa-Lobos.

Nos primeiros contatos com a editora Max Eschig, a diretoria do estabelecimento afirmou que os manuscritos por ela publicados estavam sob sua responsabilidade, em arquivos fechados, ou seja, em 
arquivos não disponíveis no catálogo público da $\mathrm{BnF}$ (documento 1). Assim, os arquivos mencionados somente poderiam ser consultados e fotografados sob permissão expressa da depositária (documento 2). No entanto, ao abrir tais arquivos, percebeu-se surpreendentemente a ausência de vários manuscritos publicados por essa editora. Ao indagar à diretoria do estabelecimento sobre a localização desses documentos, fui informado de que "após inquirir muitas pessoas", concluiu-se que tais documentos teriam sido provavelmente "apagados pelo tempo" (documento 3).

Nessa comunicação relatou-se que, nos anos 1930, representantes da Max Eschig foram incumbidos de realizar a mudança do apartamento da Place St. Michel, em Paris, onde Villa-Lobos viveu durante alguns anos. Assim, foram enviadas ao Brasil dezenas de caixas que "nunca chegaram ao seu destino". A direção da editora Max Eschig recusou-se a assumir as informações em carta oficial (documento 4). Mesmo assim, anexaram-se ao projeto todas as correspondências com a direção da editora (cartas oficiais e e-mails) por tratar-se de documentos importantes que atestam o infeliz destino desses manuscritos. Na tabela 1 apresentamos a localização dos manuscritos das canções analisadas de Villa-Lobos no Museu Villa-Lobos e na Biblioteca Nacional da França. Faz-se necessária a abertura de um inquérito institucional para investigar of icialmente o destino desses documentos que fazem parte do patrimônio artístico musical brasileiro. Cabe ao Ministério Público e à sociedade demonstrar o devido apreço por sua herança cultural.

Uma parte da revisão crítica compara os manuscritos e esboços disponíveis no Brasil e na França com as edições publicadas das canções. Encontraram-se vários erros, alguns comprovados pela presença dos manuscritos e outros musicologicamente prováveis. No caso específico dessas canções, os erros comprovados são todos de origem editorial. Os erros prováveis surgiram de estudos estilísticos, analíticos e comparativos, considerando-se também os diversos arranjos e edições em que essas melodias reaparecem. 
Tabela 1. Localização dos manuscritos de Villa-Lobos

\begin{tabular}{|c|c|}
\hline Nome das canções & Sítio do manuscrito \\
\hline \multicolumn{2}{|l|}{ Canções típicas brasileiras } \\
\hline Mokocê cê-maká & BnF, Paris, França (1) \\
\hline Nozani-ná & BnF, Paris, França (1) \\
\hline Papai Curumiassu & desaparecido \\
\hline Xangô & BnF, Paris, França (1) \\
\hline Estrela é lua nova & BnF, Paris França (1) \\
\hline Viola quebrada & desaparecido \\
\hline Adeus Ema & desaparecido \\
\hline Pálida Madona & desaparecido \\
\hline Tu passaste por este jardim & desaparecido \\
\hline Cabôca de Caxangá & desaparecido \\
\hline Pássaro fugitivo & Museu Villa-Lobos, Rio de Janeiro, Brasil \\
\hline Itabaiana & Museu Villa-Lobos, Rio de Janeiro, Brasil \\
\hline Onde o nosso amor nasceu & Museu Villa-Lobos, Rio de Janeiro, Brasil \\
\hline \multicolumn{2}{|l|}{ Três poemas indígenas } \\
\hline Canidê Iounê-Sabath & desaparecido \\
\hline Teiru & desaparecido \\
\hline Iara & $\begin{array}{l}\text { Esboço, Museu Villa-Lobos, Rio de Janeiro, } \\
\text { Brasil }\end{array}$ \\
\hline \multicolumn{2}{|l|}{ Modinhas e canções I } \\
\hline Canção do marinheiro & Museu Villa-Lobos, Rio de Janeiro, Brasil \\
\hline Lundu da marquesa de Santos & Museu Villa-Lobos, Rio de Janeiro, Brasil \\
\hline Cantilena & Museu Villa-Lobos, Rio de Janeiro, Brasil \\
\hline A gatinha parda & Museu Villa-Lobos, Rio de Janeiro, Brasil \\
\hline Remeiro de São Francisco & Museu Villa-Lobos, Rio de Janeiro, Brasil \\
\hline Nhapopé & Museu Villa-Lobos, Rio de Janeiro, Brasil \\
\hline Evocação & Museu Villa-Lobos, Rio de Janeiro, Brasil \\
\hline \multicolumn{2}{|l|}{ Modinhas e canções II (1) } \\
\hline Pobre peregrino & $\begin{array}{l}\text { BnF, Paris, França, e } \\
\text { Museu Villa-Lobos, Rio de Janeiro, Brasil (2) }\end{array}$ \\
\hline Vida formosa & $\begin{array}{l}\text { BnF, Paris, França, e } \\
\text { Museu Villa-Lobos, Rio de Janeiro, Brasil (2) }\end{array}$ \\
\hline Nesta rua & $\begin{array}{l}\text { BnF, Paris, França, e } \\
\text { Museu Villa-Lobos, Rio de Janeiro, Brasil (2) }\end{array}$ \\
\hline
\end{tabular}


Tabela 1. Continuação

\begin{tabular}{l|l}
\hline Modinhas e canções II & \\
\hline Manda tiro, tiro, lá & $\begin{array}{l}\text { BnF, Paris, França, e } \\
\text { Museu Villa-Lobos, Rio de Janeiro, Brasil (2) }\end{array}$ \\
\hline João Cambuête & $\begin{array}{l}\text { BnF, Paris, França, e } \\
\text { Museu Villa-Lobos, Rio de Janeiro, Brasil (2) }\end{array}$ \\
\hline Na corda da viola & $\begin{array}{l}\text { BnF, Paris, França, e } \\
\text { Museu Villa-Lobos, Rio de Janeiro, Brasil (2) }\end{array}$ \\
\hline Duas serestas & $\begin{array}{l}\text { BnF, Paris, França, e } \\
\text { Museu Villa-Lobos, Rio de Janeiro, Brasil (3) }\end{array}$ \\
\hline Serenata & desaparecido \\
\hline Voo & \\
\hline Deux paysages & BnF, Paris, França \\
\hline Manhã na praia & BnF, Paris, França \\
\hline Tarde na Glória &
\end{tabular}

(1) Quatro manuscritos disponíveis em transcrição para canto e orquestra.

(2) Dois manuscritos semelhantes, mas com diversas observações a lápis.

(3) Dois manuscritos diferentes, em tonalidades diversas.

Além dos manuscritos citados na tabela 1, utilizaram-se as seguintes fontes suplementares para análise comparativa com os manuscritos:

\section{CORO A CAPPELLA}

CANTO ORFEÔNICO - 1ํVLUME

32. Nozani-ná

\section{CANTO ORFEÔNICO - 2ำ VOLUME}

14. Canção do marinheiro

21. Evocação

22. Canidê Iounê-Sabath

23. Um canto que saiu das senzalas

24. Xangô

37. Estrela é lua nova

44. Remeiro de São Francisco 


\section{GUIA PRÁTICO - 1ํVLUME}

59. A gatinha parda (1 ${ }^{\mathrm{a}}$ versão) coro a 2 vozes

60. A gatinha parda (2 2 versão) coro a 2 vozes

66. João Cambuête coro a 1 voz ou canto e pf ou conjunto instrumental

73. Manda tiro, tiro, lá coro a 1 voz ou canto e pf ou conjunto instrumental

82. Nesta rua coro a 2 vozes

99. Pobre peregrino coro a 1 voz ou canto e pf ou conjunto instrumental ou pf

132. Vida formosa coro a 1 voz ou canto e pf ou conjunto instrumental

\section{CANTO E ORQUESTRA}

\section{Modinhas e canções - Álbum no 1}

1 - Canção do marinheiro

$f l$, ob, c ing, cl(Bb), sax alto, fg, 3cor, trp, trb, tuba, hp e cordas

2 - Lundu da marquesa de Santos (Viriato Correia)

3 - Cantilena (Um canto que saiu das senzalas)

4 - A gatinha parda

5 - Remeiro de São Francisco 2fl, 2ob, c ing, 2cl(Bb), 2fg, 4cor, 2trb, tuba, tímp, hp e cordas

6 - Nhapopé (Alberto Deodato)

7 - Evocação (Sylvio Salema) pic, 2fl, 2ob, c ing, cl(Bb), 2fg, cfg, 4cor, trp, 2trb, tuba, tímp, hp, celesta e cordas

Autógrafos (MVL):

- Canção do marinheiro - xerox - 8 p.

- Canção do marinheiro, L undu da marquesa deSantos, Cantilena, A gatinha parda e Nhapopé - partes de fl, ob, cl(Bb), fg, cor, trb, hp e cordas

- Remeiro deSão Francisco - heliográfica, s.d. - 3p.

- Evocação - heliográfica, s.d. - 8 p.

Não publicadas 
Modinhas e canções - Álbum no 2

(1958/1959, NY)

1 - Pobre peregrino

pic, 2fl, 2ob, c ing, 2cl(Bb), cl baixo, 2fg, cfg, 2cor, 2trp, trb, tuba, timp, prato, triângulo, hp e cordas

3 - Nesta rua

$f l, o b, 2 c l(B b), 2 f g, 2 c o r$, timp, hp e cordas

4 - Manda tiro, tiro, lá

2fl, 2ob, 2cl(Bb), 2fg, 2cor, tímp, hp e cordas

Autógrafos (MVL):

- Pobre peregrino - xerox vegetal, s.d. - 3 p.

- Nestarua- vegetal, s.d. - 8 p.

- M andatiro, tiro, lá- xerox vegetal, s.d. - 3 p.

Não publicadas 


\section{Documento 1}

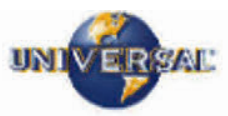

UNIVERAL MUSJC PUBLISHING GROUP

Dossier de Monsieur Nahim Marun

\section{ATTESTATION}

Je soussignte Patriciz Alia. Assistarte de Direction des Ecitions DurandSAlabert-Eechig (Universa Mlısiz Publishing): arteste par la presente que notre Directeur Avtistique. Monsieur Gérald Hugon, accompagnera Monsieur Nahim Marun pour ses recherches d̀ la Bibliotheque Nationale de France oú sont en óppot les manuscrila des couvres musicates de Heitor Vila-Lobos (dont des partitions pour voix et piano) dont les Écitions Durand-Salabert-Eschig sont piopxiétuires.

Fait à Paris fo 9 juillot 2008

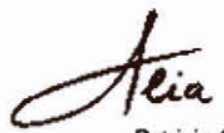

Patricia Alia

Potncia.alla@umüsle. $\infty$ !n

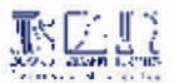

UNIVENSAL MUSIC PUBLTSIIING MUH rKANCZ

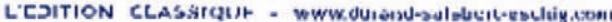

I6 AUE UES SOSSFE SAIVT-JACOUES - ?JJUS IaKIS

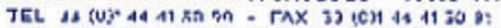

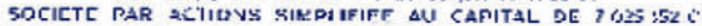

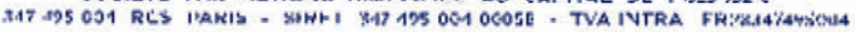




\section{Documento 2}

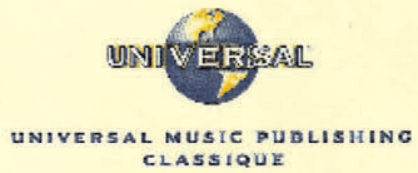

\section{AUTORISATION}

Je soussignee Patricia Ala, Assistante de Direction des Éditions DurandSalabert-Eschig (Universal Music Publishing Classical) autorise par la présente Monsieur Nahim Marun, pour ses recherches à la Bibliotheqque Nationale de France, à consulter et à photocopier des extraits des manuscrits des ceuvres musicales de Heitor Villa-Lobos pour voix et piano dont les Éditions Eschig (Durand) sont propriétaires.

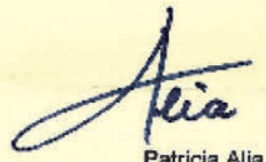

patricia.alia@umusic.com

EOITIONS DUIRAND - SALABERT - ESCHIC

16 RUE DES FOSSES SAINI JACDUES - 7500G PARIS

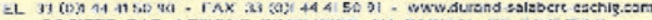

SOCIETE DAF ACTION' SIMPLIFILE AU COAIIAI II , DAS W

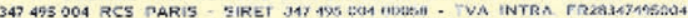

A UNIVERSAL MUSIC PUOLISHING COMPANY

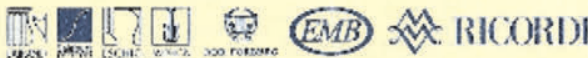




\section{Documento 3}

Em 27/1/2010 07:27, Alia, Patricia < Patricia.Alia@umusic.com escreveu:

Cher Monsieur,

Désolée de vous répondre si tard, mais j'ai dû interroger plusieurs personnes pour vous répondre correctement.

Effectivement, Eschig ne conserve dans ses archives que 4 des manuscrits des Chansons typiques brésiliennes de Villa Lobos: 1/ Mokocê cê maka

2/ Nozani na

4/ Xango

5/ Estrela e ua nova

Toutes traces des autres manuscrits de ces chansons semblent avoir été effacées par le temps.

Il est probable que les manuscrits recher chés des œuvres en question (Chansons E Poèmes) aient disparus quand Eschig, en charge de liquider en 1930 l'appartement de Villa Lobos Place Saint-Michel, a renvoyé au compositeur au Brésil des caisses pleines de ses documents, livres et manuscrits... dont certaines ne lui sont jamais parvenues. Les œuvres correspondent tout à fait à cette époque.

Avec mes meilleurs sentiments.

Patricia

\section{Patricia Alia}

\section{Promotion}

\section{$\mathcal{E}$ Assistante de Direction}

Durand-Salabert-Eschig (Universal Music Publishing Classical) http://www.durand-salabert-eschig.com

16 rue des Fossés Saint-Jacques - 75005 Paris

tél. 0144415020

De : Nahim Marun [mailto:nmarun@uol.com.br]

Envoyé : mercredi 20 janvier 2010 12:29

À : Alia, Patricia

Objet : info sur manuscrits 
Chère Madame,

Je suis allé chez Eschig en demandent une lettre de permission pour rechercher aux archives Villa-Lobos. Je vous remercie beaucoup. Vous avez été infiniment cordial et vous avez ouvert les chémins pour mes travaux. Toutefois, je n'ai pas trouvé quelques manuscrits publiés chez Eschig. Ils ne sont pas au Musée Villa-Lobos à Rio et non plus à BnF. Ces manuscrits là sont, précisément:

- 10 Chansons Typiques Brésiliennes - Je n'ai trouvé que quatre à la BnF. - Trois Poèmes Indigenes - Ils non plus, il ne sont pas à la BnF. J'ai emporté un esquisse de la troisième (Iara) du Musée Villa-Lobos.

Sauriez-vous où peut-on trouver ces manuscrits publiés chez Eschig? Je suis très reconnaissant pour votre attention.

Cordialement, Nahim Marun.

\section{Documento 4}

De:Alia, Patricia

Para:Nahim Marun

Assunto:RE: Retour au Brésil

Data:26/4/2010 04:12

Cher Monsieur,

J'espère que votre séjour à Paris a été profitable et agréable.

Je ne peux malheureusement vous faire une "attestation officielle" pour des suppositions quant à la situation des manuscrits de Villa-Lobos, comprenez-le, car mes informations ne sont en aucun cas vérifiables.

Avec mon meilleur souvenir,

Patricia

\section{Patricia Alia}

\section{Promotion}

Durand-Salabert-Eschig (Universal Music Publishing Classical) http://www.durand-salabert-eschig.com

16 rue des Fossés Saint-Jacques - 75005 Paris - tél. 0144415020 


\section{1 \\ AsPeCTOS HISTÓRICOS}

O intenso fluxo cultural ocorrido no início do século XX entre Brasil e França foi decisivo na produção artística de Heitor VillaLobos. A pesquisa histórica é importante em qualquer revisão crítica por esclarecer aspectos do processo composicional, sugerindo caminhos para o processo analítico de várias situações musicais, redimindo dúvidas no confronto das edições com as várias versões de manuscritos e esboços - ou, no caso da ausência dos mesmos, apontando metodologias adequadas para a mais acurada análise possível. Processos históricos influenciam diretamente a prática da performance. ${ }^{1}$ Dos princípios da técnica da performance emanam vários fundamentos estéticos da linguagem de seu tempo que refletem muitas das práticas sociais e artísticas de sua época e trazem para seus domínios os maneirismos vocais e instrumentais e muitas das normas vigentes de notação e interpretação musicais.

Segundo Paulo Guérios (2003, p.84-90), a proclamação da República no Brasil, em novembro de 1889, levou a sociedade a aspirar a uma modernização dos costumes. Na música erudita,

1 Performance practice: disciplina que estuda os reflexos da história social, política e cultural na execução e na interpretação musical. 
a inspiração que era até então principalmente italiana, ligada à tradição operística de Giuseppe Verdi (1813-1901), voltou-se para a música francesa de Camille Saint-Saëns (1835-1921) e alemã de Richard Wagner (1813-1883). Assim, em sua juventude, Villa-Lobos foi influenciado pela estética tradicional italiana e pela moderna estética de Wagner e Saint-Saëns e admirava a revolucionária estética de Debussy. Na década de 1920, o compositor embarcou para a Europa e passou dois grandes períodos em Paris, desenvolvendo relações frutíferas com o meio artístico francês.

Na França, o compositor manteve importantes laços de amizade com músicos como o compositor Edgar Varèse (1883-1965) e o pianista Arthur Rubinstein (1887-1982). Este último estimulou-o esteticamente e encomendou-lhe novas obras. Villa-Lobos chegou pela primeira vez à capital francesa em 1923 e realizou o célebre concerto histórico na Salle des Agriculteurs. Segundo Beaufils (1988, p.180), nesse mesmo ano seu amigo e incentivador Arthur Rubinstein apresentou-o ao editor Max Eschig, fato que precipitou a publicação e a divulgação de sua obra na Europa.

Suas relações com o meio cultural parisiense estão registradas em vários livros sobre a vida cultural da capital francesa no início do século XX, como, por exemplo, no livro de Segonzac (1993, p.26882), Marguerite Long, un siècle de vie musicale française, no qual há um capítulo dedicado à grande amizade entre Villa-Lobos e a grande pianista francesa. Há menções às atividades de alunos brasileiros de Mme. Marguerite Long (1874-1966), como o pianista João de Souza Lima (1898-1982) e o maestro Eleazar de Carvalho (1912-1996), assim como vários comentários sobre as estreias de concertos e obras de Villa-Lobos. O compositor brasileiro intermediou convites de turnês a Mme. Long, viabilizando três viagens da artista ao Brasil, com realizações de concertos, recitais, entrevistas e aulas públicas.

O poeta Manuel Bandeira (1886-1968) menciona algumas das influências desse período europeu na obra de Villa-Lobos na Revista Ariel, de 1947. Bandeira afirma que a audição da Sagração da primavera, de Igor Stravinsky (1882-1971), "o abalou perigosamente". Segundo Guérios (2003a, p.139), 
a similaridade entre a música brasileira de Villa-Lobos e a Sagração da primavera, que Villa-Lobos negava ter origem na própria música do compositor russo, faz com que o cronista trace a hipótese da similaridade entre a métrica dessa obra e a métrica dos indígenas sul-americanos. Na verdade, o fato de Villa-Lobos ter alterado a data de várias composições - como Nonetto, Trio, Uirapuru, Amazonasem que utiliza elementos da técnica de Stravinsky, situando-as como anteriores a sua ida à Europa, fez com que surgissem hipóteses bastante elaboradas, seja sobre a existência de um modernista intuitivo, gerado pela natureza dos trópicos brasileiros, seja sobre uma suposta similaridade das culturas russa e brasileira, que teriam gerado frutos tão parecidos.

Villa-Lobos entrou em contato com as ideias de pensadores expressivos da vida parisiense como Marcel Proust (1871-1922), Jean Cocteau (1889-1963), Blaise Cendrars (1887-1961), Eric Satie (1866-1925), o Groupe des Six: George Auric (1899-1983), Francis Poulenc (1899-1963), Louis Durey (1888-1979), Germaine Tailleferre (1892-1983), Arthur Honegger (1892-1955) e Darius Milhaud (1892-1974). Segundo Nichols (2002, p.258), Milhaud, com a suíte para piano Saudades do Brasil, ${ }^{2}$ "serviu confortavelmente ao gosto francês pelo exótico - isto é: melodicamente simples, harmonicamente colorido e ritmicamente repetitivo - e trilhou o caminho para a real música sul-americana de Villa-Lobos" que logo chegaria a Paris. Segundo Guérios (2003, p.84-90) o contato com a arte francesa provocou em Villa-Lobos uma grande revitalização da sua música, aprofundando sua busca por uma arte mais simples, direta e tipicamente brasileira, impulsionando ou mesmo provocando as diversas fases artísticas vividas pelo compositor.

Em um artigo sobre os concertos franceses para piano escritos nos anos 1930, Grenier (2000, p.292) enumera várias características

2 Segundo partitura da editora Max Eschig, a suíte Saudades do Brasil, 12 danças com nomes dos bairros cariocas, foi composta para piano solo em $1920 \mathrm{e}$ orquestrada um ano mais tarde pelo compositor. Darius Milhaud esteve no Brasil entre 1917 e 1918 com Paul Claudel, em missão cultural. 
estilísticas da época, que podemos certamente estender à música de Villa-Lobos.

Ao contrário do século XIX, que privilegia o lirismo das frases, o caminho harmônico, o sopro de obras inspiradas por eventos pessoais variados, o jogo do intérprete, os anos 1930 cultivam a estética de uma música franca, muitas vezes mesmo rude, que valoriza os aspectos percussivos do piano, misturando as tonalidades, justapondo os gêneros musicais, as canções populares, os estilos de escritura pianística, as harmonias simples e complexas.

Essas foram algumas ideias musicais defendidas por compositores do Groupe des Six, como Milhaud, Poulenc e Tailleferre, e outros representantes próximos da estética neoclássica. Desse modo, a música de Villa-Lobos agradou ao gosto francês e encaixou-se perfeitamente ao gosto parisiense da época. Segundo Porcile (1999, p.389), Paul Le Flem (1881-1984), professor de Erik Satie na Schola Cantorum, ${ }^{3}$ quando crítico musical à Comœdia escreveu que amava o frescor e a truculência da música de Villa-Lobos e se sentia "seduzido por sua melodia suntuosa, seu ritmo voluntarioso, sua orquestra em ebulição, rica de imprevisto e de cor".

De acordo com Fléchet (2004, p.13), "em Paris, ele [Villa-Lobos] se descobre brasileiro e reinventa o nacionalismo musical". A arte ocidental não valoriza mais os valores universalistas (ou mesmo os etnocentristas), mas caminha para uma destruição da razão ocidental, pela crítica marxista, pela psicanálise ou pelo surrealismo (idem, p.19). Nesse momento, a imagem de um Brasil negro e índio fascina a arte europeia e em especial a arte francesa. A estratégia de Villa-Lobos foi aproveitar essa tendência, construindo uma rede de influências para a divulgação e para o sucesso e o reconhecimento de sua obra. Nichols (2002, p.258) informa que quando Villa-Lobos

3 Schola Cantorum foi uma famosa escola de Paris na qual estudaram inúmeros compositores e artistas reconhecidos. Villa-Lobos foi um dos professoresconvidados dessa entidade, durante um período de sua estada parisiense. 
veio novamente a Paris em 1930, ele estava determinado: se era exotismo que Paris desejava, então ele lhe daria exotismo. A imprensa escrita da França proclamava uma alma brasileira sempre selvagem, rude, gritante e desconexa. Obviamente, os brasileiros que residiam no Brasil não ficaram felizes com esse compositor que os fazia parecer ridículos em Paris.

Em artigo sobre a Chanson au cinéma dans les années trente, Basile (2000, p.241) demonstra que na década de 1930 "o público francês procurava esquecer a morosidade e os problemas da época, abandonando-se ao sonho que as imagens lhe proporcionavam". Assim, podemos confirmar em diversas publicações que o apelo de um mundo distante, indígena e exótico fascinava a sociedade francesa. Pistone demonstra em seu artigo Les conditions historiques de l'exotisme musical français (1981, p.11-22) que as raízes do gosto pelo exótico remontam na verdade à época de Jean-Baptiste Lully (1632-1687) e Christoph Willibald Glück (1714-1787), passando pelas influências da conquista da Argélia e das exposições universais de 1872, 1878 e 1889, influências que adentraram pelo século XX com a arte japonesa e afro-americana. Pistone assinala que "o gosto pelo exótico foi um capítulo da nossa cultura, mas permanece um eterno apelo no imaginário francês”.

Segundo Basile (2000, p.242), "George Auric, Arthur Honegger, Jacques Ibert, Maurice Jaubert, Joseph Kosma, Darius Milhaud e Jean Wiéner não tinham nenhum desprezo pela expressão popular sob todas as suas formas, incluindo-se aí a chanson".

As suítes de canções villa-lobianas, com sua simplicidade e exotismo, entram rapidamente para o establishment musical francês, aumentando sua popularidade e influenciando várias gerações de compositores. Nyeki (2000, p.543) informa que no início do século XX o compositor e crítico musical Florent Schmitt (1870-1958) chama o compositor húngaro Tibor Harsányi (1898-1954) de "VillaLobos do Norte" por sua música de "uma natureza altiva e tão belamente desordenada" e por seu "refinamento cru da harmonia". Segundo Nichols (2002, p.258), "a diversidade métrica da música 
de Villa-Lobos, sua complexidade, sua força ardente e abundância impressionaram o jovem Olivier Messiaen (1908-1992), que mais tarde descreveu o compositor como um orquestrador de enorme grandeza”. 


\section{2 \\ Paradigmas nas canções de VILLA-Lobos}

Paradigma é um exemplo que serve como modelo, padrão. Do grego parádeigma, é um pressuposto, uma teoria ou um conhecimento que origina o estudo de um campo científico, uma realização científica com métodos e valores que são concebidos como modelo, uma referência inicial como base para estudos e pesquisas. ${ }^{1} \mathrm{Em} \mathrm{Lin}$ guística, Ferdinand de Saussure (1857-1913) define como paradigma (paradigmáticos) o conjunto de elementos similares que se associam na memória e que assim formam conjuntos relacionados ao significado (semântico). A análise paradigmática é uma prática corrente de análise musical, segundo Meeùs (1993, p.4): "Em música, seu foco está principalmente na identificação das repetições, das redundâncias e analogias que vão das mais simples às mais complexas".

A música das canções de Villa-Lobos relaciona-se integralmente com o sentido emocional do texto, ou seja, devemos considerar sempre as influências do conteúdo expressivo do campo semântico. Assim, uma análise das canções agrupadas em paradigmas poderá estabelecer similaridades e conexões estilísticas e contribuir para o

1 Dicionário Aulete de língua portuguesa. Disponível em: <http://educacao.uol. com.br/dicionarios/>. 
estudo e a compreensão do estilo musical de Villa-Lobos. Segundo Meeùs (idem, p.1-3), a compreensão do estilo de um compositor é, na verdade, determinada por suas relações associativas e por suas analogias.

"Comparamos para delimitar, dentro dos sistemas de dois ou mais objetos, suas semelhanças e suas diferenças significativas, até que elas formem outro sistema, uma figura simples, uma evolução ou uma natureza" (Ehret, 2009, p.39). O gênero canção desvenda aspectos particulares e importantes do estilo de um compositor por reunir a música e a literatura. Conforme os conceitos de Meeùs (1992, p.3), há no caso um fenômeno diassemiótico, que significa uma correspondência entre dois sistemas semióticos: um sistema é usado como metalinguagem do outro.

Podemos perceber no cancioneiro de Villa-Lobos que a língua portuguesa arcaica determina um tratamento similar no musical, como na modinha Lundu da marquesa de Santos e nas Canções Típicas Brasileiras Tu passaste por este jardim e Pálida Madona. Nessas canções observamos uma linha melódica operística, à maneira das árias italianas em voga no século XIX. Por um lado a linha melódica é ampla, inspirada no bel canto, e o fraseado é tipicamente tonal, privilegiando cadências perfeitas. Por outro, a língua portuguesa popular/urbana demanda a adoção de um estilo sentimental evocativo da música popular, desenvolvendo melodias seresteiras na mão esquerda do pianista, à la manière de la guitarre, como na seresta Serenata e na canção Viola quebrada. As frases são amplas e suas finalizações muitas vezes trazem sensações de sensível-tônica. Quando Villa-Lobos trabalha com o português típico do interior do Brasil, como em Adeus Ema, Papai Curumiassu e Cabôca de Caxangá, encontramos igualmente uma música atrelada às origens do texto, explorando ostinatos musicais e rasqueados à la manière de la viola paysanne. Há na linha melódica uma tendência à regularidade, poucos saltos virtuosísticos e muitas notas pedais na parte pianística. Seu fraseado é muitas vezes simétrico e explora efeitos de repetição, com resoluções tonais bem definidas. 
Segundo Münch (2009, p.22), “a voz conecta a pura emoção sonora, como se fosse um substituto do sentimento, da imaginação, do pensamento e da cultura à qual pertence sua linguagem". Segundo Ehret (2009, p.33), Marc-Mathieu Münch criou um metaconceito para designar o efeito psíquico produzido por uma obra de arte a partir de sua recepção, em colaboração com o sujeito receptor: "uma expressão material específica, parte de um sistema interativo que inclui o domínio ficcional do gênio criador e de um receptor disposto a colaborar com uma percepção global da obra, deixando nascer assim um efeito específico que Münch chama de efeito de vida".

O conceito de Münch depende da coesão dos elementos artísticos envolvidos. Conjuntamente com os estados de alma (sentimentos) e aspectos formais (razão), a coerência da obra de arte provoca associações de imagens (imaginação), ou seja, determinações exógenas que são diretamente transpostas para a música por analogias mentais. A coerência na música de Villa-Lobos é fundamentada em uma filosofia fortemente calcada em valores da cultura brasileira. Sua coesão artística é atingida pela existencia de células, motivos e temas reconhecíveis, como se fossem constituídos de uma isotopia. ${ }^{2}$ Sua forma, estrutura e textura são construídas a partir de múltiplos sintagmas, que, relacionados, reelaborados e transfigurados, colocam a obra de Villa-Lobos na categoria das obras de arte capazes de tocar "não só uma faculdade do espírito mas de entrar de tal forma dentro da consciência que o estímulo original toca todas as faculdades, colocando-as em total relação" (Journeau, 2009, p.41), promovendo assim uma "percepção sinestésica". Pistone observa ainda que o "efeito de vida é instantâneo, e sobre esse instante se grafa a memória. Tal memória poderá modificar a escuta. Assim, em

2 Em linguística (e na ciência da literatura), classificam-se signos como isotópicos quando estes apresentam o mesmo significante (ou significantes bem aproximados) apesar de apontarem para significados e sentidos diferentes. Logo, por possuírem identidade formal no texto, os significantes podem ser classificados como isotópicos (Simões, 2003). 
uma segunda escuta, a experiência será totalmente diferente, pois já será uma lembrança. O público escuta com sua experiência de vida, com sua cultura" (idem, p.61-2).

As memórias dos diversos conjuntos de percussão da música popular brasileira (seja ela folclórica, africana ou popular) estão onipresentes na obra musical de Villa-Lobos. No caso de suas canções, o conjunto de percussão instrumental é traduzido pelas duas mãos do pianista em outro instrumento. Assim, por meio de recursos essencialmente pianísticos como o uso do pedal, da dinâmica, das variedades de toque e do domínio sobre o fraseado, o pianista realiza um amálgama das várias camadas rítmicas e harmônicas componentes dos ostinatos típicos dos conjuntos populares instrumentais, modificando-os, multiplicando-os e transcendendo suas características essenciais. Dessa forma estabelece-se um sistema diassemiótico, ou seja, de sistemas diversos que se espelham e se traduzem.

Conforme Meeùs (1992, p.3), “a música pode sugerir imagens visuais, mas ela pode também traduzir uma obra pictórica”. Em Modinhas e Canções, no Remeiro de São Francisco, quando as palavras evocam as águas e o movimento contínuo do remador de canoas, o discurso musical traduz o movimento dos rios. O misterioso ambiente musical de Nhapopé, da mesma compilação, explora a região grave do instrumento e traduz um poema sobre um misterioso ritual noturno. A inspiração afro-brasileira determina em Villa-Lobos o emprego de um discurso musical predominantemente modal, uma forma musical circular que explora elementos rítmicos característicos da cultura africana, carregados em ostinatos e notas pedais. A melodia é predominantemente curta, repetitiva e simétrica; as terminações dos fraseados evitam graus conjuntos e apresentam-se com terças ou quintas descendentes. Essa visão do compositor sobre os rituais afro-brasileiros se reflete nas Canções Típicas Brasileiras - Xangô, Estrela é lua nova - e nas Modinhas e Canções - Cantilena, Remeiro de São Francisco e João Cambuête. 
Quando a linguagem musical e a linguística pretendem demonstrar as múltiplas facetas do mundo infantil, como em $A$ gatinha parda e Manda tiro, tiro, lá (Modinhas e Canções), encontramos alusões às cantigas de roda, explorando uma música leve, simples e descompromissada, quase sempre carregada de elementos inesperados, refletindo assim a maneira pela qual Villa-Lobos enxergava o universo infantil.

Todas as canções com linguagem ou temática indígena correspondem em Villa-Lobos a um estilo musical ritualístico e evocativo do modus vivendi dos silvícolas, incluindo o emprego sistemático de sistemas musicais extraeuropeus. Tarasti (1995, p.223) deixa uma interrogação em seu estudo sobre Villa-Lobos, quando faz menção a uma provável utilização na interpretação do microtonalismo encontrado nos arquivos coletados por Roquette Pinto. A melódica das canções de inspiração indígena é sempre curta, assimétrica e o fraseado evita resoluções tonais arquetípicas sensível/tônica. No entanto, em Iara, das Três Canções Indígenas, encontramos uma bela solução composicional do autor. O texto de Mário de Andrade é o terceiro da série; assim, sua fonte não é direta, mas referente ao universo do indígena. Villa-Lobos opta então por uma visão também referencial, ou seja, traz em sua música uma reinterpretação do índio brasileiro, com a utilização de um estilo refinado e complexo quanto à escolha dos parâmetros formais, harmônicos e melódicos.

Encontramos exemplos metafóricos em obras inscritas dentro da fase neoclássica do compositor, "nas quais o emprego da modalidade é inscrito dentro de um contexto harmônico e rítmico clássico", emprestando as palavras de Elias (1995, p.67). Assim, na canção Manhã na praia, das Deux Paysages, observamos uma melodia que "sobe" vagarosamente às regiões cada vez mais agudas "como um balão vermelho". Vejamos também a sonoridade reluzente apresentada pelo piano ao envolver o canto de "os globos de cristal se enchem de luz”, em Tarde na Glória, da mesma série. Na seresta número 14, 
Voo, observamos uma escritura pianística contínua e ondulante que explora as regiões agudas do instrumento, fato esse que confere uma volatilidade metafórica ao texto de Abgar Renault.

Alguns aspectos harmônicos estudados na obra pianística de Villa-Lobos por Elias (idem, p.152) aparecem como paradigmas harmônicos em suas canções e serão estudados adiante. São eles: emprego de progressões cromáticas; emprego de numerosos acordes sobre pedal, seja inferior, seja superior; emprego de grande número de acordes alterados; emprego pontual de atonalidade, de bi ou politonalidade; emprego de clusters; emprego de grande número de notas estranhas à harmonia e de resoluções inesperadas; empregos de arpejos e cadências à la guitarra; emprego do diatonismo e do contraponto. Ainda conforme Elias (idem, p.107), os quatro ramos temáticos da obra pianística de Villa-Lobos são por vezes recorrentes nas canções: "obras centradas sobre a natureza, obras com temas infantis relevantes, obras ligadas a temas de lendas ou de festas tradicionais e obras ligadas ao tema dos sentimentos, incluindo-se temas de expressões étnicas e à la manière de la guitarre".

A seguir, na tabela 2, apresentamos alguns dos paradigmas encontrados nas canções de Villa-Lobos. Analisaram-se as semelhanças gerais entre seus sistemas harmônicos, suas relações com o texto, forma e aspectos estilísticos. As canções foram divididas em quatro categorias principais:

1) canções indígenas e afro-brasileiras;

2) canções populares brasileiras com texto em língua brasileira popular-urbana, campesina, ou infantil;

3) canções eruditas brasileiras com texto em português arcaico;

4) canções contemporâneas, com texto brasileiro erudito. 


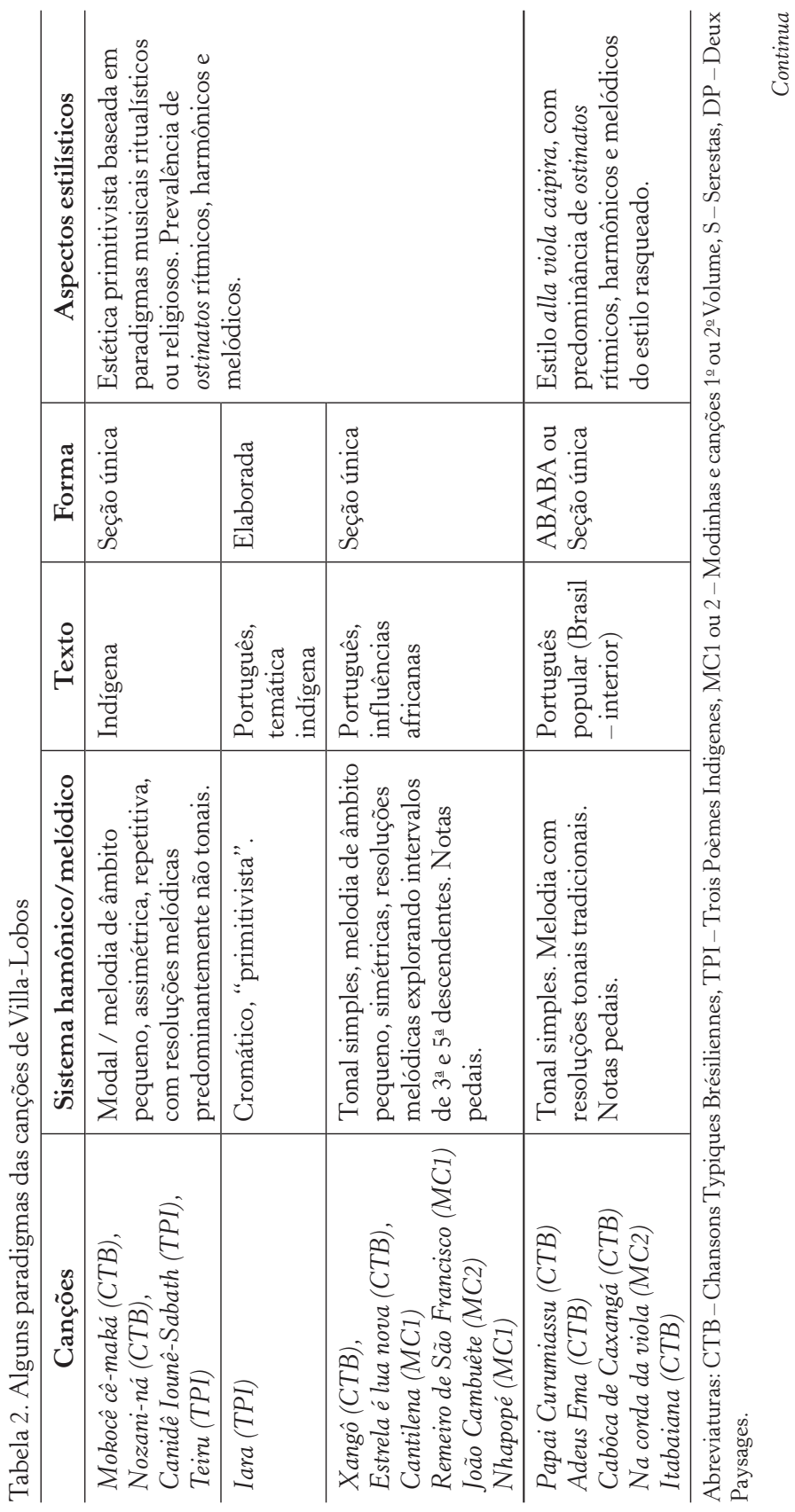




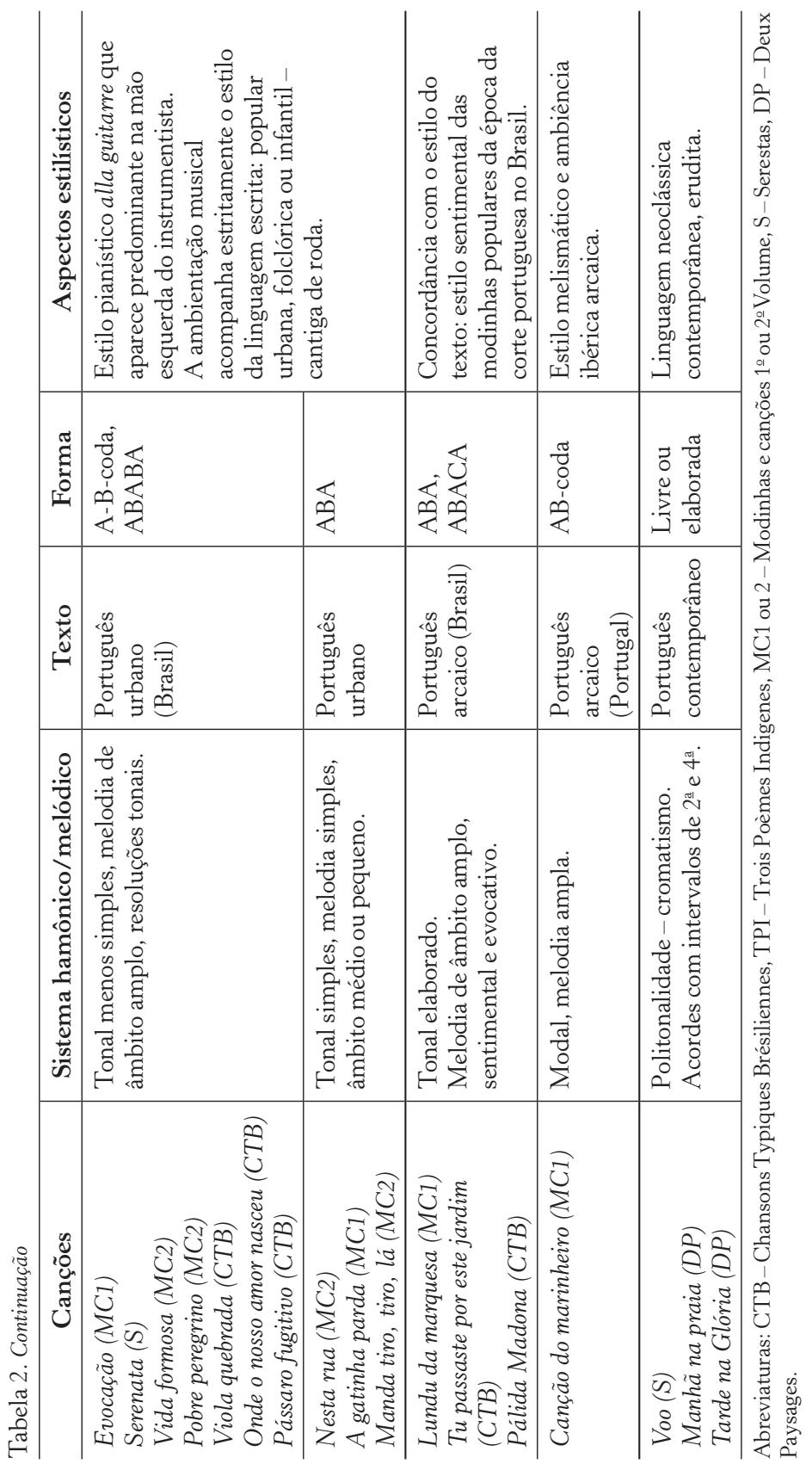




\section{3 \\ REVISÃO CRÍTICA}

A revisão crítica das canções de Villa-Lobos vem somar-se aos esforços para o entendimento e clarificação da obra do compositor, juntando-se aos trabalhos desenvolvidos por importantes maestros e musicólogos brasileiros que divulgam e revisam a obra instrumental e orquestral de Villa-Lobos. Segundo o maestro Roberto Duarte (2009, p.29), "qualquer trabalho escrito, seja livro, jornal, revista ou um simples anúncio, antes de ser publicado tem que ser minuciosamente revisado, mesmo em se tratando de grandes autores". No caso de Villa-Lobos, Duarte prefere não usar a palavra erro e sim esquecimento, distração ou engano. "Erro é um termo muito forte quando se trata de compositores geniais."

Para este livro, valemo-nos da visão de Duarte (idem, p.37), que afirma que "revisar é estudar a fundo não só a partitura, mas o conjunto da obra do compositor. É limpar aqueles pequenos, porém incômodos lapsos, com o único objetivo de fornecer aos intérpretes e finalmente ao público, partituras dignas da grandeza do compositor". Muitos dos erros presentes nas canções para voz e piano deVilla-Lobos são lapsos editoriais da editora Max Eschig e não foram cometidos por Villa-Lobos nos manuscritos. SeVilla-Lobos revisou as partituras antes da sua impressão, tais lapsos passaram despercebidos pelo compositor. Citaremos outra afirmativa de Duarte (idem, p.40), "de que o próprio criador da obra de arte não é o seu melhor revisor". 


\section{Chansons Typiques Brésiliennes (Canções Típicas Brasileiras)}

Tabela 3. Canções Típicas Brasileiras, data da composição/publicação, gênero e texto

\begin{tabular}{|c|c|c|c|}
\hline $\begin{array}{l}\text { Mokocê cê- } \\
\text { maká }\end{array}$ & $\begin{array}{l}\text { 1919, 1929, Éditions } \\
\text { Max Eschig }\end{array}$ & canção indígena & $\begin{array}{l}\text { recolhida por } \\
\text { Roquette Pinto }\end{array}$ \\
\hline Nozani-ná & $\begin{array}{l}\text { 1919, 1929, Éditions } \\
\text { Max Eschig }\end{array}$ & canção indígena & $\begin{array}{l}\text { recolhida por } \\
\text { Roquette Pinto }\end{array}$ \\
\hline $\begin{array}{l}\text { Papai } \\
\text { Curumiassu }\end{array}$ & $\begin{array}{l}\text { 1919, 1929, Éditions } \\
\text { Max Eschig }\end{array}$ & canção de caboclo & não informado \\
\hline Xangô & $\begin{array}{l}\text { 1919, 1929, Éditions } \\
\text { Max Eschig }\end{array}$ & $\begin{array}{l}\text { canto religioso } \\
\text { macumba }\end{array}$ & não informado \\
\hline $\begin{array}{l}\text { Estrela é lua } \\
\text { nova }\end{array}$ & $\begin{array}{l}\text { 1919, 1929, Éditions } \\
\text { Max Eschig }\end{array}$ & $\begin{array}{l}\text { canto fetiche } \\
\text { macumba }\end{array}$ & não informado \\
\hline $\begin{array}{l}\text { Viola } \\
\text { quebrada }\end{array}$ & $\begin{array}{l}\text { 1919, 1929, Éditions } \\
\text { Max Eschig }\end{array}$ & modinha & $\begin{array}{l}\text { M. de A. (Mário de } \\
\text { Andrade) }\end{array}$ \\
\hline Adeus Ema & $\begin{array}{l}\text { 1919, 1929, Éditions } \\
\text { Max Eschig }\end{array}$ & desafio & $\begin{array}{l}\text { popular do estado } \\
\text { de Minas Gerais }\end{array}$ \\
\hline $\begin{array}{l}\text { Pálida } \\
\text { Madona }\end{array}$ & $\begin{array}{l}\text { 1919, 1930, Éditions } \\
\text { Max Eschig }\end{array}$ & modinha antiga & poesia popular \\
\hline $\begin{array}{l}\text { Tu passaste } \\
\text { por este } \\
\text { jardim }\end{array}$ & $\begin{array}{l}\text { 1919, 1930, Éditions } \\
\text { Max Eschig }\end{array}$ & modinha carioca & $\begin{array}{l}\text { tema de Alfredo } \\
\text { Dutra, letra de } \\
\text { Catullo Cearense }\end{array}$ \\
\hline $\begin{array}{l}\text { Cabôca de } \\
\text { Caxangá }\end{array}$ & $\begin{array}{l}\text { 1919, 1930, Éditions } \\
\text { Max Eschig }\end{array}$ & $\begin{array}{l}\text { embolada do } \\
\text { Norte }\end{array}$ & $\begin{array}{l}\text { tema e letra de } \\
\text { Catullo Cearense }\end{array}$ \\
\hline $\begin{array}{l}\text { Pássaro } \\
\text { fugitivo }\end{array}$ & 1935 , não editada & canção sertaneja & $\begin{array}{l}\text { recolhida por } \\
\text { Severino Rangel }\end{array}$ \\
\hline Itabaiana & 1935, não editada & $\begin{array}{l}\text { canção sertaneja } \\
\text { indígena }\end{array}$ & $\begin{array}{l}\text { popular do estado } \\
\text { da Paraíba do Norte }\end{array}$ \\
\hline $\begin{array}{l}\text { Onde o nosso } \\
\text { amor nasceu }\end{array}$ & 1935, não editada & $\begin{array}{l}\text { modinha } \\
\text { brasileira }\end{array}$ & não informado \\
\hline
\end{tabular}

As Canções Típicas Brasileiras foram compostas no Rio de Janeiro, Brasil, e foram dedicadas à cantora Elsie Houston. ${ }^{1}$ Segundo

1 Segundo Beaufils (1988, p.181), a cantora Elsie Houston participou dos concertos históricos na Salle Gaveau em 24 de outubro e 5 de dezembro de 1927, em Paris. 
Peppercorn (1991, p.30), não é certa a data em que Villa-Lobos arranjou essas Chansons Typiques Brésiliennes, "pois as canções não trazem as datas e algumas delas foram estreadas somente em 14 de março de 1930". Segundo justificativa da autora, "o título do ciclo está em francês e muitas das músicas compostas entre 1923 e 1926 tiveram origem na mesma fonte de ideias. Portanto, assume-se que essas canções foram escritas durante sua visita a Paris ou logo após”. Segundo Wright (1992, p.35), essa foi uma das primeiras manifestações do compositor em direção a uma liberação da arte pelo folclore.

Segundo o Museu Villa-Lobos, a canção no11, Pássaro fugitivo, a nำ12, Itabaiana, e a nำ13, Onde o nosso amor nasceu, datadas de 1935, não foram publicadas. Como informação suplementar para a análise do conjunto da suíte, essas canções foram anexadas ao final da revisão das Canções Típicas Brasileiras.

De acordo com o Museu Villa-Lobos, as primeiras audições das obras foram:

12.4.1929, Porto Alegre - Teatro São Pedro. Nozani-ná, Estrela é lua nova e Xangô. Andino Abreu, canto; Elysena d'Ambrosio, piano.

28.5.1935, Buenos Aires - Sala del Teatro Cervantes. Viola quebrada, Itabaiana e Onde o nosso amor nasceu (no mesmo programa, Xangô e Estrela é lua nova). Stefana de Macedo, canto; Heitor VillaLobos, piano.

25.7.1942, Rio de Janeiro - Salão Leopoldo Miguez da Escola de Música do Rio de Janeiro. Mokocê cê-maká. Maria Figueiró Bezerra, canto; Geraldo Rocha Bezerra, piano.

27.1.1947, Paris - Salle Chopin. Viola quebrada, Estrela é lua nova e Tu passaste por este jardim. Madeline Gruf, canto; Gilberto Lacompté, piano. Primeira audição em Paris.

De acordo com Appleby (1988, p.42-43), a estreia europeia de Mokocê cê-maká, Nozani-ná e Xangô aconteceu em Paris, Salle Chopin, Orchestre de Chambre, Croiza, soloist, Villa-Lobos, cond., em 3.4.1930. 


\section{Mokocê cê-maká}

"Dorme na Rede. Canção para acalentar as criançinhas entre os índios paricis." A canção é uma canção de ninar, razão pela qual determina a estruturação baseada na repetição dos elementos do texto e da música. Segundo Wright (1992, p.37), o hipnótico ostinato do acompanhamento imita as improvisações anasaladas das flautas características das berceuses dos índios parecis. A melodia foi coletada pelo etnologista Roquette Pinto.

\section{Texto}

Êná môkôcê cêmáká, Êná môkôcê cêmáká, Êná môkôcê cêmáká, Êná môkôcê cêmáká,

Uirômôkôcê cêmáká, Uirômôkôcê cêmáká, Uirômôkôcê cêmáká,

Êná môkôcê cêmáká, Cêmáká

Máká

á

\section{Estruturação formal e harmônica}

Segundo Elias (1995, p.138), quando Villa-Lobos intenciona dar um caráter primitivo às suas obras musicais, concebe-as a partir de temas indígenas originais ou de traços melódicos específicos das músicas dos indígenas do Brasil, ou seja: repetição de uma só nota, escalas pentatônicas, cromatismo dentro de escalas com âmbitos muito curtos, emprego de escalas modais.

A forma é simples com seção única. O piano inicia o movimento com um ostinato que percorrerá toda a canção. Após dois compassos 
o canto inicia uma melodia cromática, sempre descendente, à maneira de um lamento.

A canção é construída sobre uma escala sobre a nota ré, que, sem armadura, configura um modo dórico. A mão esquerda do pianista contém o intervalo característico do modo: ré - si natural, entre o baixo e sua nota mais aguda. $\mathrm{O}$ cromatismo da canção encobre um pouco as características modais da canção. Em seu livro sobre a obra de Villa-Lobos, Tarasti (1995, p.223) discute o fato de o cromatismo da canção Mokocê cê-maká ter uma natureza microtonal, a exemplo dos fonogramas coletados por Roquette Pinto. Tarasti não toma partido, mas chama a atenção para o fato de o original coletado por Roquette Pinto pertencer a outro sistema musical, que poderá ser uma ponte de comunicação com a música de Villa-Lobos.

As frases do canto têm uma periodicidade constante, mas totalmente irregular. Assim, o canto desloca-se ao longo da canção com relação ao piano. As duas frases iniciais do canto têm uma periodicidade em seis tempos, o que causa um deslocamento rítmico com o compasso regular e periódico do piano, sempre em compasso 5/8. A terceira frase possui uma pausa adicional ao final, o que lhe confere sete tempos. Seguem a quarta e quinta frases com cinco tempos cada e a sexta frase com seis tempos e a mesma pausa no seu final. A sétima frase tem quatro tempos e a oitava, cinco tempos. Para finalizar a canção, encontramos duas frases curtas, interrompidas, para configurar a diluição musical da coda.

No quarto e sétimo versos (compassos 6 e 10) há um ponto culminante na voz, que circunda o quinto e sexto versos, que, por sua vez, têm uma sonoridade mais grave e escura. $\mathrm{O}$ verso oito retorna à sonoridade do início, seguido de uma diluição do movimento.

\section{Aspectos interpretativos}

Sugerimos ao pianista sustentar a oitava ré- $2 /$ ré-3 com o pedal harmônico, ou tonal, durante toda a canção. Indicamos também um dedilhado que servirá para toda a canção: 


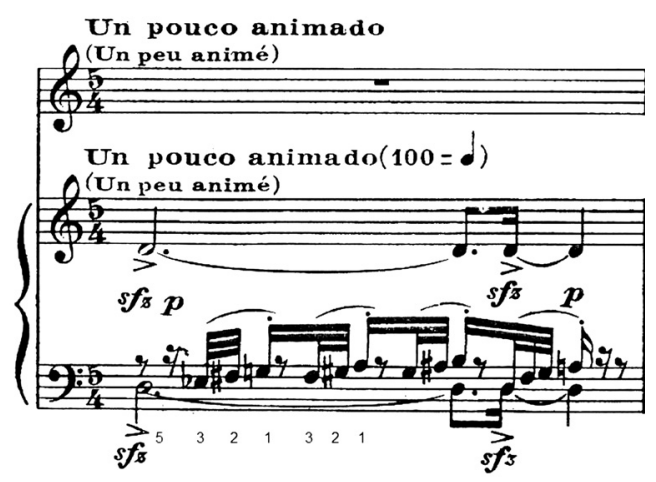

Villa-Lobos. Mokocê cê-maká, introdução.

Éditions Max Eschig, Paris, 1929.

\section{Orquestração}

A canção foi orquestrada por Villa-Lobos para canto solista acompanhado de flauta, oboé, corne inglês, clarinete em lá, fagote, viola e violoncelo. No manuscrito da Biblioteca Nacional da França, há uma indicação na linha do corne inglês: "Poderá ser substituído por saxofone contralto".

\section{Edição e manuscritos}

1. Não há indicação metronômica no manuscrito.

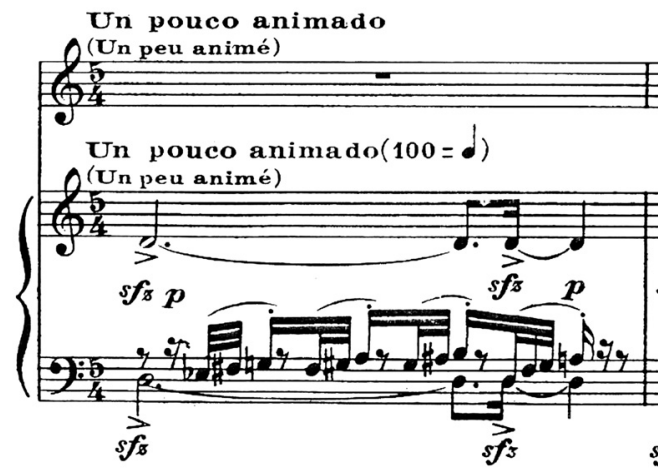

Villa-Lobos. Mokocê cê-maká, introdução.

Éditions Max Eschig, Paris, 1929. 


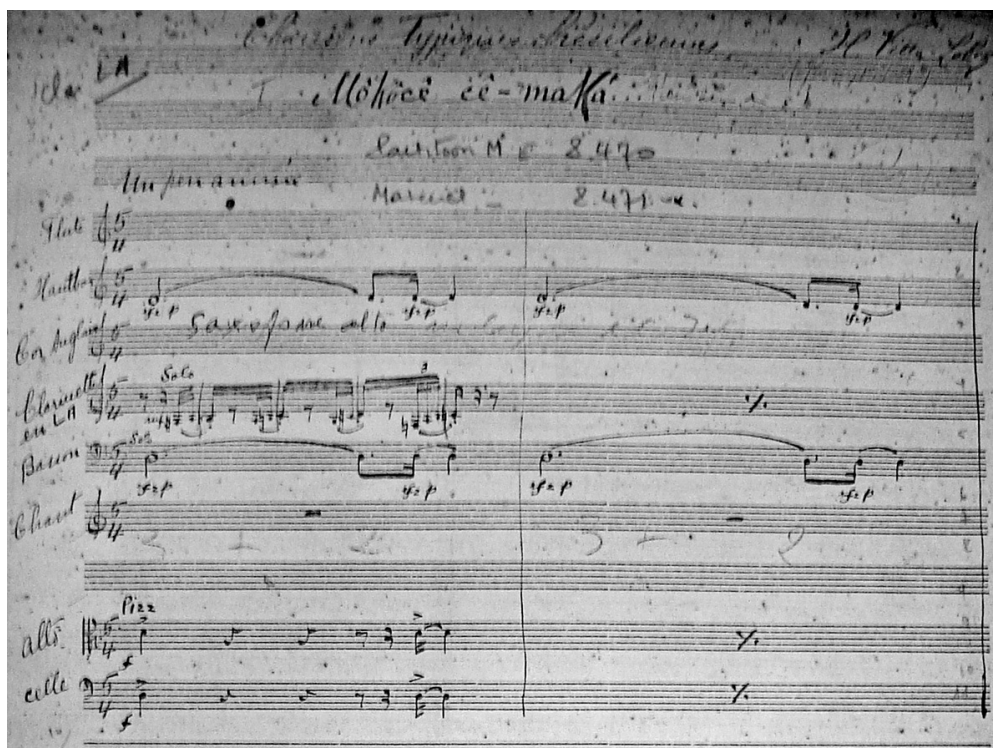

Villa-Lobos. Mokocê cê-maká, Introdução, versão orquestral. Manuscrito, Biblioteca Nacional da França, Paris.

2. Falta o sinal indicativo de tercinas:
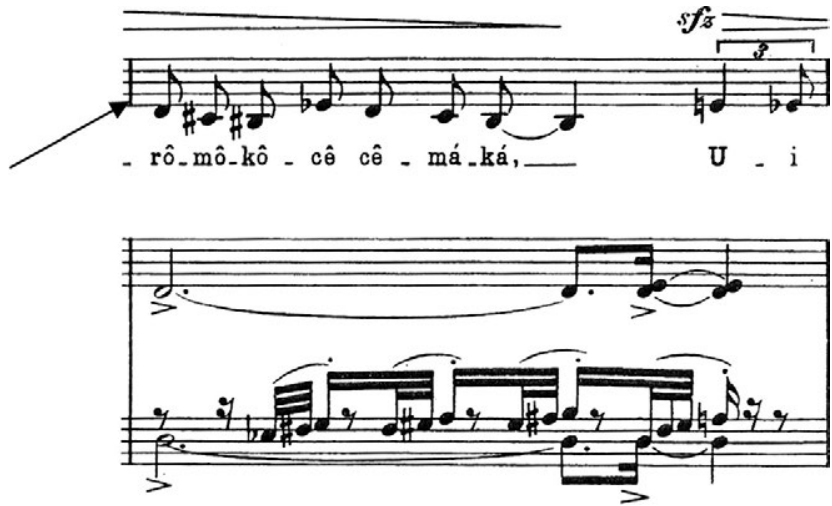

Villa-Lobos. Mokocê cê-maká, compasso 8. Éditions Max Eschig, Paris, 1929. 
3. Falta o sinal de staccato:

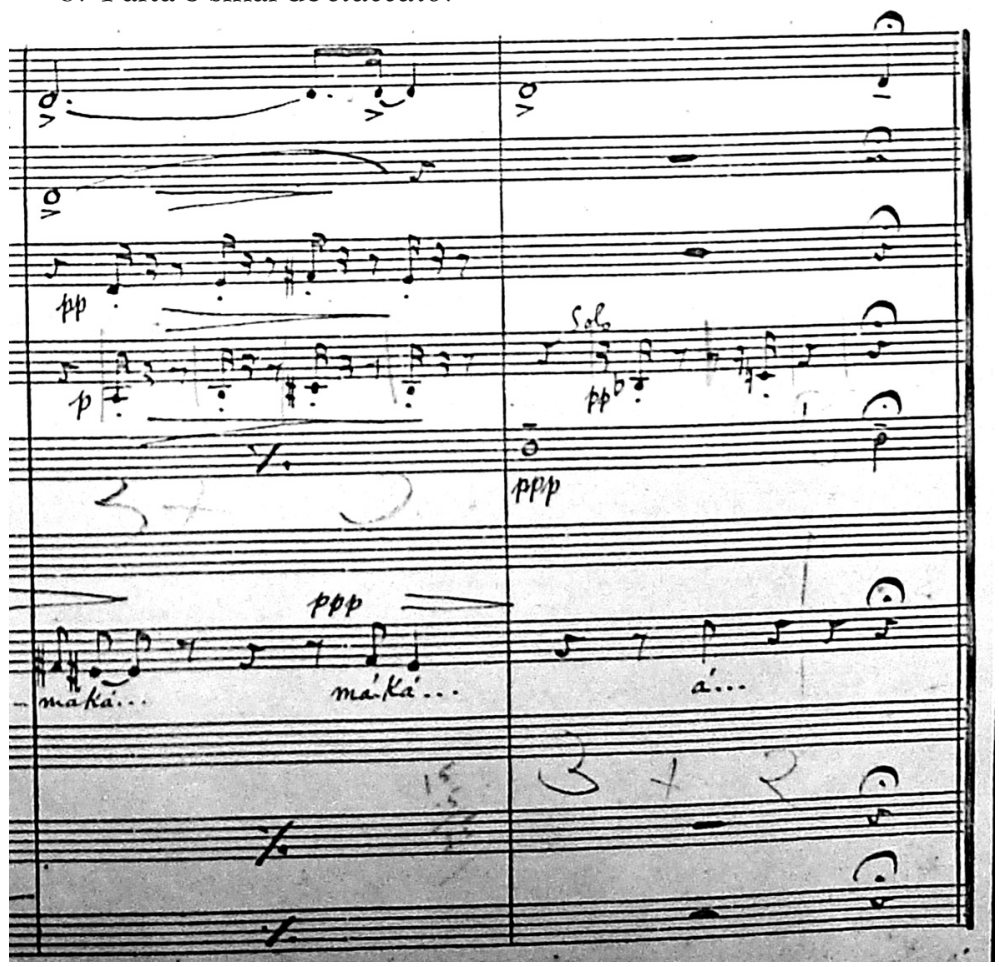

Villa-Lobos. Mokocê cê-maká, compassos 12-3.

Manuscrito da versão orquestral, Biblioteca Nacional da França, Paris.
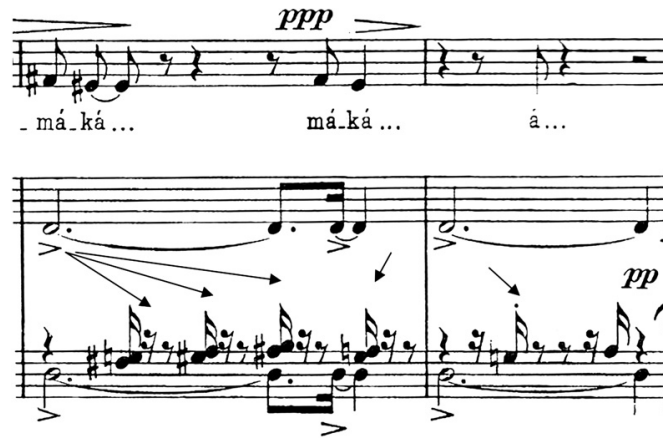

Villa-Lobos. Mokocê cê-maká, compassos 12-3. Éditions Max Eschig, Paris, 1929. 


\section{Nozani-ná}

Canto dos índios parecis da Serra do Norte (Mato Grosso). VillaLobos escreveu em epígrafe que a obra foi baseada no fonograma no14.597 do Museu Nacional do Rio de Janeiro. Segundo Wright (1992, p.37), "a melodia de Nozani-ná logo ganhou grande significado para Villa-Lobos e toma em seu trabalho um sentido quase simbólico como representante maior do indianismo”. Em uma análise (idem, p.50), Wright assinala a correspondência entre o tema de Nozani-ná e o baixo da célebre obra para piano Rudepoema, dedicada ao pianista Arthur Rubinstein (compassos 1 a 6). Wright também demonstra que Nozani-ná é o tema principal dos Choros no3, "uma rapsódia coral sobre a canção dos índios parecis” (idem, p.64).

\section{Texto}

Na coleção para canto orfeônico que Villa-Lobos reuniu em 1940, essa canção aparece com o nํㅜㄴ. A melodia é exatamente a mesma, porém há palavras com vogais diferentes e acentuação e articulações diversas. É importante assinalar que a articulação e a acentuação das palavras determinam a escolha do fraseado musical do canto, que será acompanhado pelo pianista.

\section{Texto (partitura para voz e piano)}

Nozani ná orê kuá, kuá,

Kaza êtê, êtê,

Nozani na orê kuá, kuá,

Nozani noterahan, rahan,

Oloniti, niti,

No terahan, kozêtozá, tozá,

Nôtêrá, têrá

Kenakiá, kiá

Nêê êná, êná

Uálálô, lálô,

Giráhalô, halô

Uai!

\section{Texto (partitura para coro} a cappella)

Noza niná Orêkuá kuá, Kazaêtê, êtê

Noza niná Ôrekuá kuá

Noza niná terahau rahau

Oloniti niti

Notêrahau kozeto zá tozá

Notêrá terá

Kená kia kia

Nêêêná êná

Uá lalô, lalô

Giráhalô halo

Uai 
ग०32 Nozan1-ná

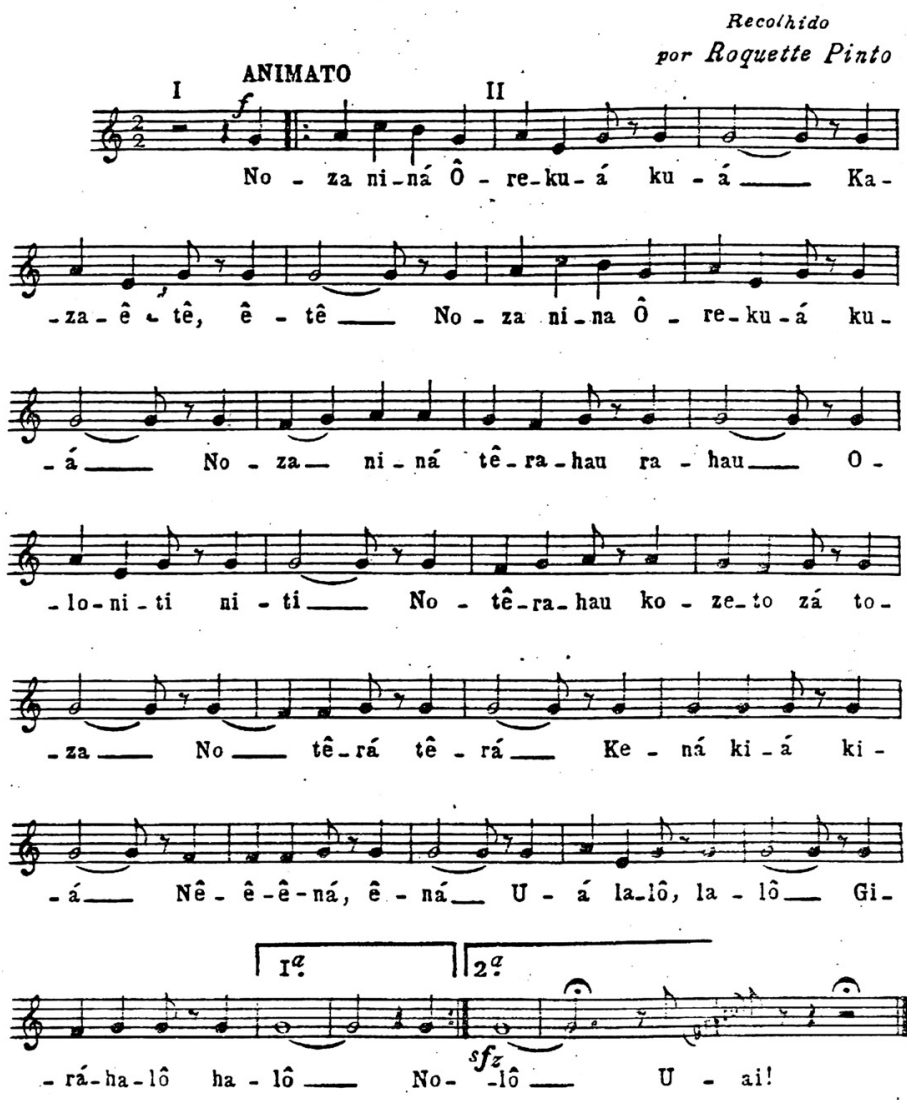

Villa-Lobos. Nozani-ná, versão para coro a cappella, 1ํv., nำ32.

Editora Irmãos Vitale, São Paulo, 1940.

\section{Estrutura formal e harmônica}

\section{A melodia é hexatônica: sol-lá-si-dó-mi-fá.}

Não há armadura de clave, mas há uma polarização da melodia na nota sol. A nota fá aparece sempre natural, tanto na melodia quanto no piano, o que poderia sinalizar o emprego do modo mixolídio. A nota ré que caracteriza a dominante de sol não aparece na melodia. 
O acompanhamento é muito simples, baseado somente em dois acordes: dó maior com intervalos de sétima e nona acrescentados e fá maior com intervalos de sétima e nona acrescentados, permeados por um ostinato rítmico.

\section{Aspectos interpretativos}

Aconselhamos ao pianista sustentar com o pedal harmônico ou tonal a nota sol-3 durante toda a canção. A indicação sans la pédale toujours refere-se ao pedal direito.

Alguns dedilhados úteis:

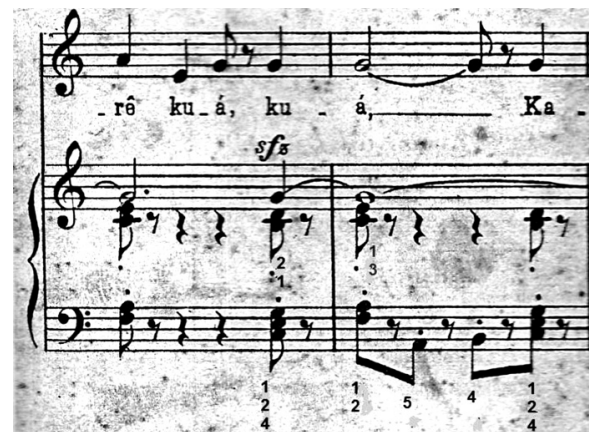

Villa-Lobos. Nozani-ná, dedilhados compassos 5-6. Éditions Max Eschig, Paris, 1929.

\section{Orquestração}

O manuscrito presente na Biblioteca Nacional da França possui a seguinte orquestração: canto solista, clarinete em si bemol, duas trompas e um quinteto de cordas.

\section{Edição e manuscritos}

1. Na partitura editada que está no Museu Villa-Lobos há um esboço de orquestração do compositor, que aparece concretizada no manuscrito orquestral que está nos arquivos da Max Eschig na Biblioteca Nacional da França, em Paris. É importante observar que não há indicação de metrônomo na versão orquestral. 


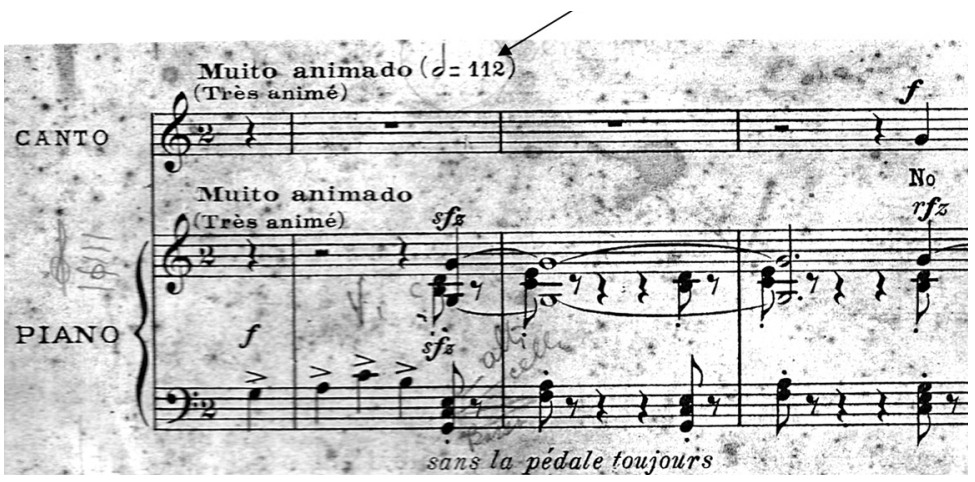

Villa-Lobos. Nozani-ná, versão para canto e orquestra.

Éditions Max Eschig, Paris, 1929.

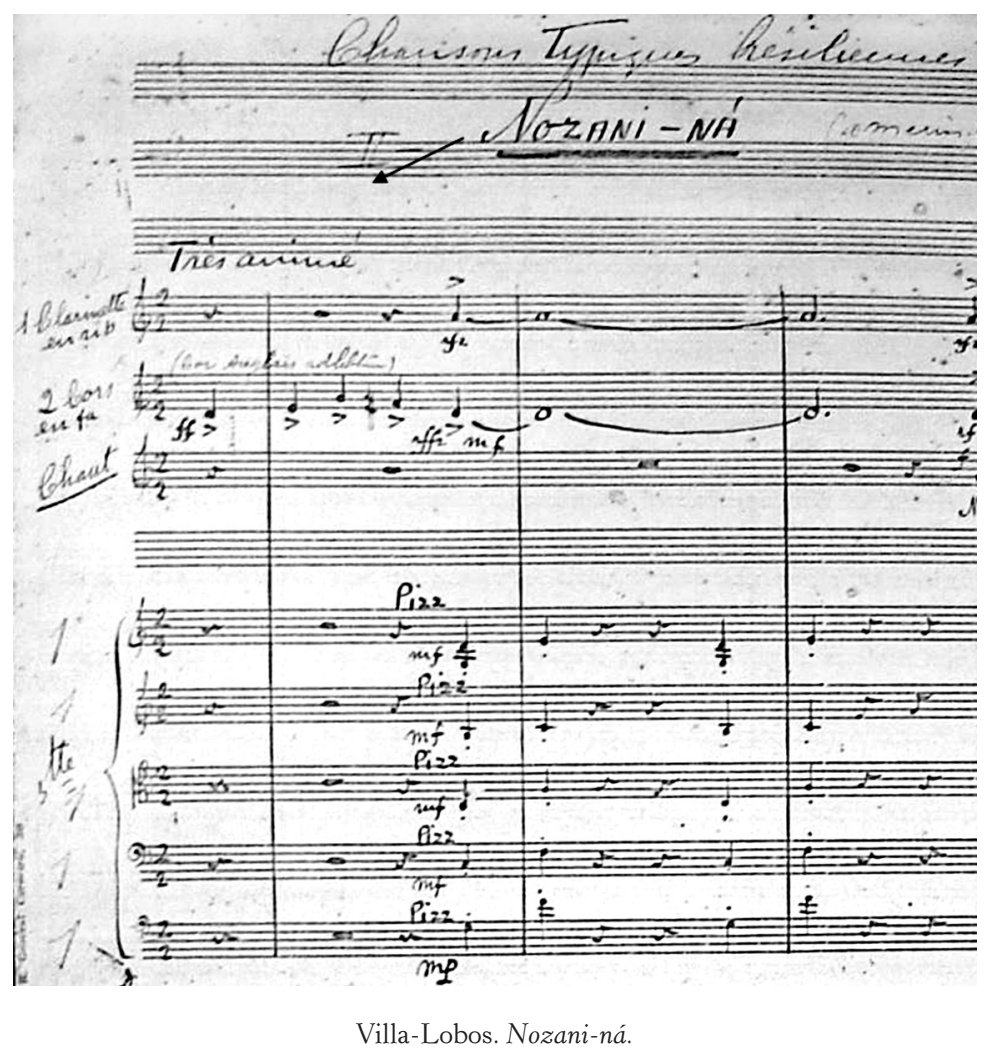

Manuscrito da transcrição para canto e orquestra, Biblioteca Nacional da França, Paris. 
2. Não há sinal de fermata na partitura editada para voz e piano pela Max Eschig.

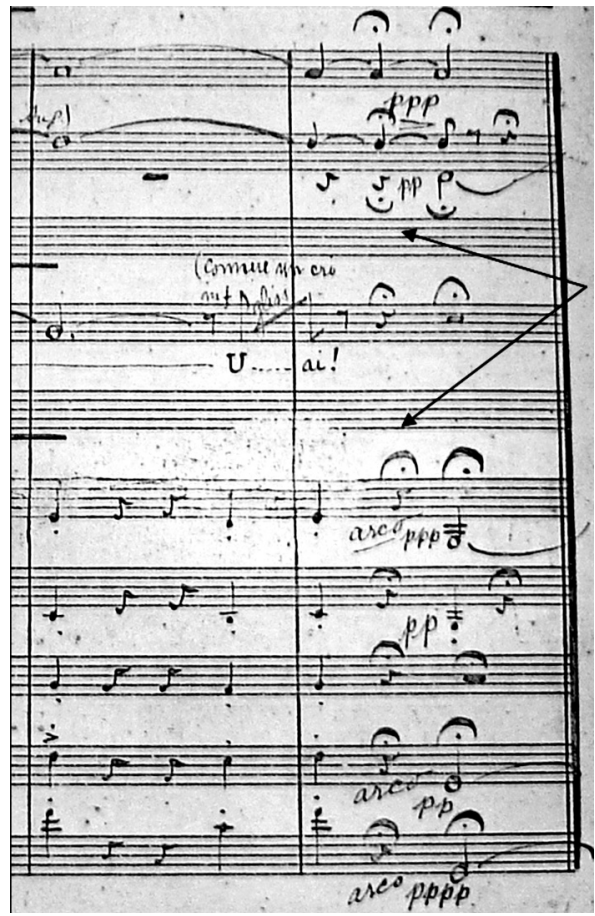

Villa-Lobos. Nozani-ná, versão para canto e orquestra. Biblioteca Nacional da França, Paris.

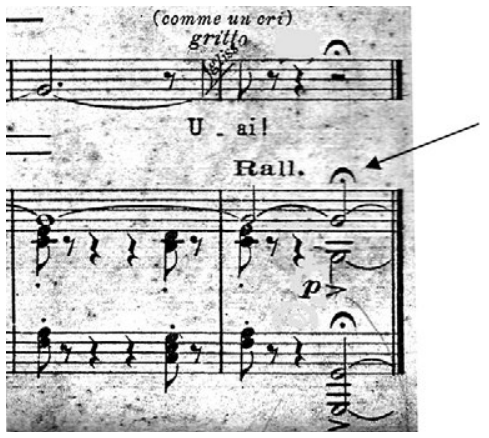

Villa-Lobos. Nozani-ná.

Éditions Max Eschig, Paris, 1929. 


\section{Papai Curumiassu}

\section{Texto}

Canção de rede entre os caboclos² do Pará

Papai Curumiassú,

Papai

Mamãe Curumiary

O gallo canta da serra meu gallo canta dahí. Galo, daí

Meu gallo canta dahí

Galo, daí

Schô! Gallo ingrato...

Galo

\section{Estrutura formal e harmônica}

Canção formada por uma seção única. $\mathrm{O}$ acompanhamento é um ostinato acompanhado de um acorde quase imóvel. Fórmula de compasso ternário, pontuada algumas vezes por uma fórmula de compasso quaternário, que confere um movimento rítmico singular à canção, evocando o Idílio na rede, título da primeira obra da Suíte Floral para piano solo.

Tonalidade: dó menor. De acordo com Tarasti (1995, p.224), Papai Curumiassu tem um sabor ligeiramente pentatônico.

\section{Edição e manuscritos}

O manuscrito dessa canção está desaparecido. Em face desse fato, não houve possibilidade de comparação da edição com as fontes primárias. Assim, anotamos algumas observações baseadas na análise musical.

1. Os cinco sinais de arpejo, a partir do compasso 15, não estão grafados corretamente. Vejamos: se a quinta do baixo é ligada ao compasso anterior, não há sentido no sinal de arpejo assinalado

2 Caboclo, segundo o Dicionário Aulete de língua portuguesa, é um mestiço de branco com índio. 
desde o baixo. Observar a última seta, que aponta para o único arpejo que foi grafado corretamente, dois compassos antes do final da canção.
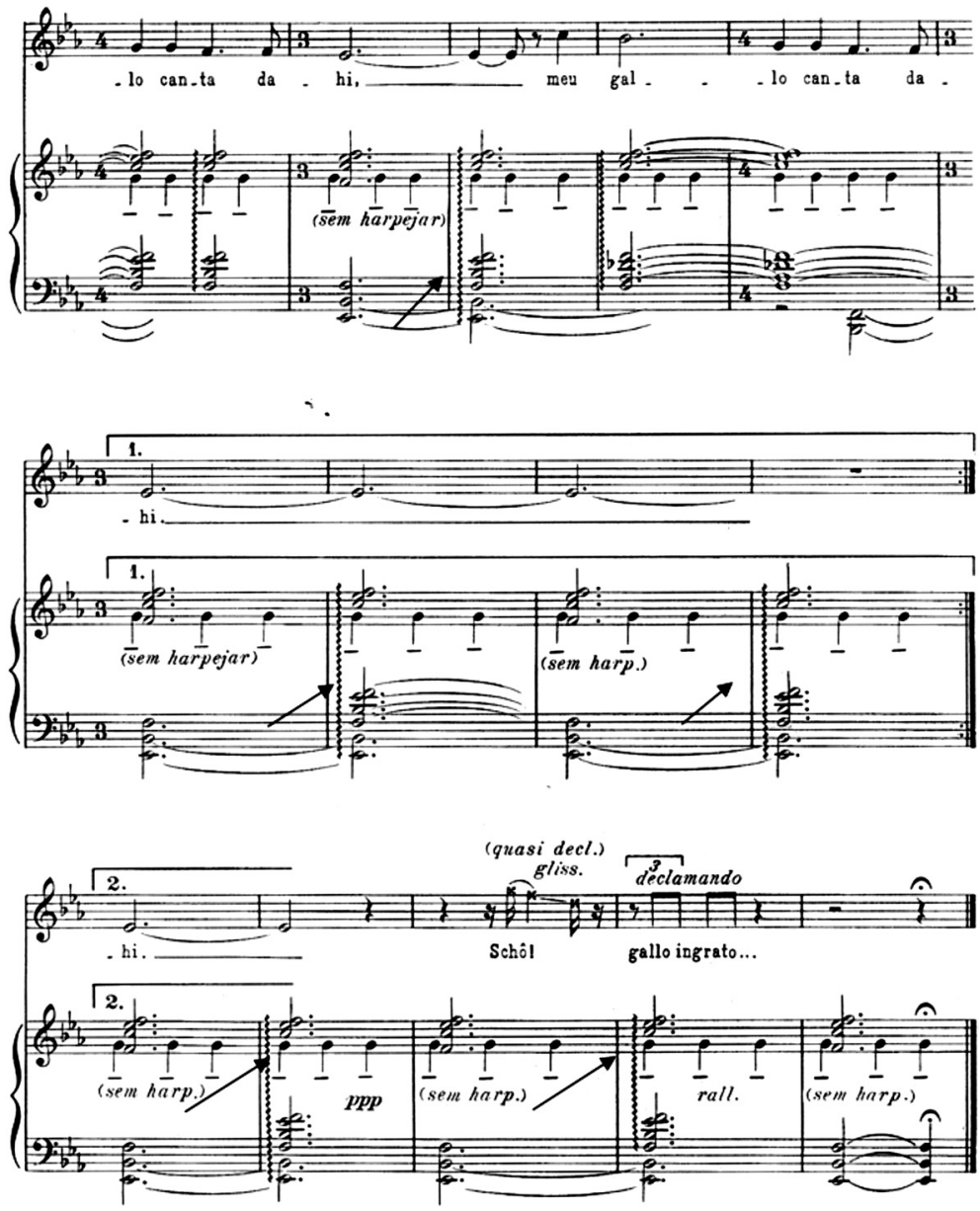

Villa-Lobos. Papai Curumiassu, compasso 15 ao fim. Éditions Max Eschig, Paris, 1929. 


\section{Xangô}

Canto fetiche de macumba ${ }^{3}$ do Brasil.

\begin{tabular}{l|l}
\hline \multicolumn{1}{c|}{ Texto publicado por Max Eschig } & Texto publicado por Irmãos Vitale \\
\hline Xangô! & Xangô! \\
\hline Ôlê gondilê & Olê gendilê! \\
\hline Olá lá! & Ôlá! Lá! \\
\hline Gon gon gon gon gon dilá! & Gon! Gon! Gon! Gon! Gon, dilá! \\
\hline Xangô & Xangô! \\
\hline Ôlê gondilé & Ôle gendilê \\
\hline Olê lệ! & Ôlê! lệ! \\
\hline Gon gon gon gon gon dilé! & Gon! Gon! Gon! Gon! Gon, dilê! \\
\hline
\end{tabular}

Existem duas versões do texto, uma publicada pela Max Eschig, de Paris, e outra pela Irmãos Vitale, de São Paulo. Adiante comentaremos tais edições.

\section{Estrutura formal e harmônica}

Forma estrófica simples. A estrofe inicial, dos compassos 1 a 9, é repetida quatro vezes. A melodia é construída basicamente sobre o acorde de sol menor: notas sol, si bemol, dó, ré. O acompanhamento do piano é um ostinato sobre o acorde de sol. Um trêmolo e um glissando interrompem o ostinato nos compassos 5, 9,13 e 17. Segundo Tarasti (idem, ibidem), em Xangô, "Villa-Lobos trabalha com a melodia ritmicamente aumentada (em relação ao livro-catálogo folclórico de Oneyda Alvarenga), estabelecendo uma espécie de balanço polirrítmico ao motivo quadrangular e percussivo desenvolvido pelo acompanhamento do piano".

\section{Orquestração}

A orquestração da canção foi assim realizada, conforme manuscrito depositado na $\mathrm{BnF}$ : canto solista, dois fagotes, duas trompas em

3 Macumba, segundo o Dicionário Aulete de língua portuguesa, é a denominação dada aos cultos afro-brasileiros e aos seus rituais, originários do nagô, e que receberam influências de religiões africanas, ameríndias, católica, espírita e ocultistas. 
fá, dois tímpanos em sol e ré, percussão (bumbo e tam-tam), harpa, piano e quinteto de cordas.

\section{Edições e manuscrito}

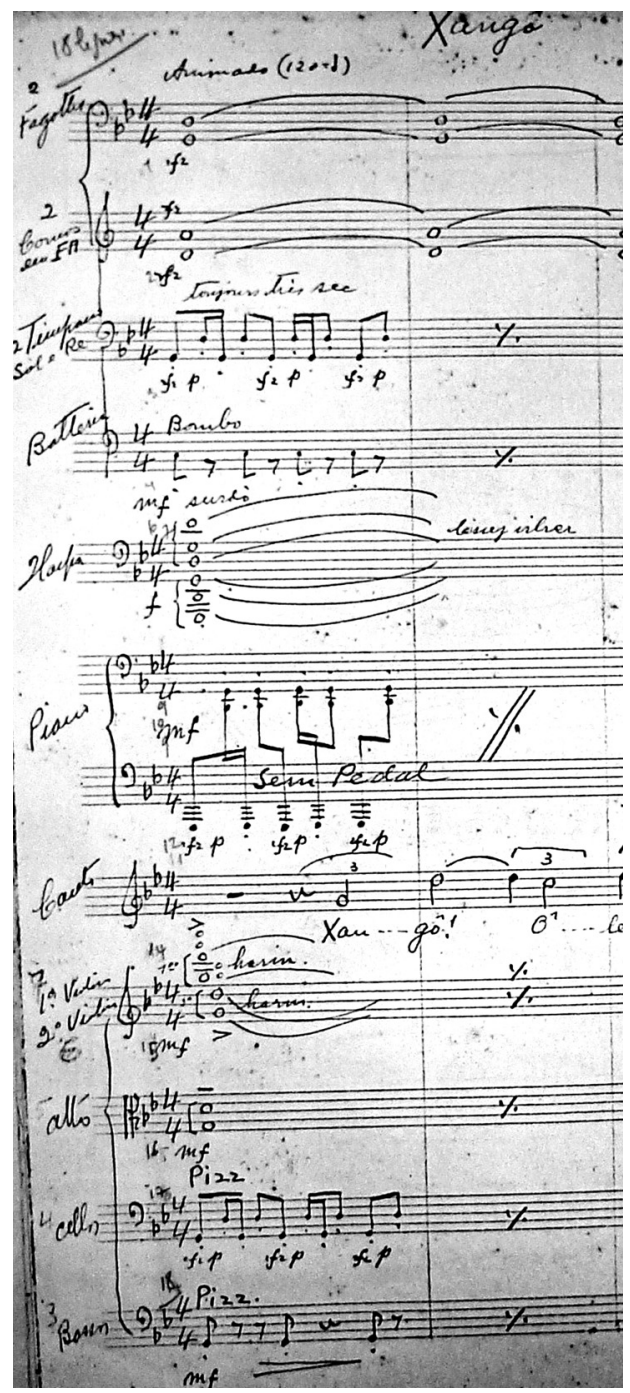

Villa-Lobos. Xangô. Manuscrito da versão orquestral, Biblioteca Nacional da França, Paris. 
Enganos de texto.

Anònimo

Xangô

Genero de Macumba

(Côro a sêco a 5 vozes) Recolhido no Rio de Jofneiroe

Amb. por H. VILLA-LOBOS

de época passada

SOPRANOS

CONTRALTOS

TENORES

24

BARITONOS BA IXOS
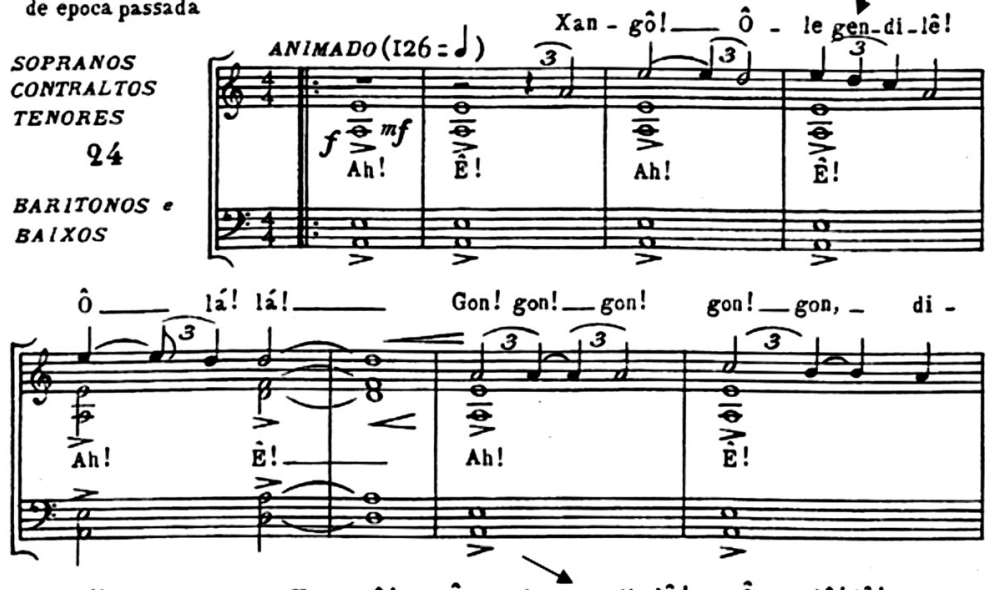

$12 !$

$$
X_{2 n}-g \hat{o} !-\hat{o}-\text { le gen-di-lê! }
$$

$\hat{0}-1 \hat{e} ! l \hat{e} !$

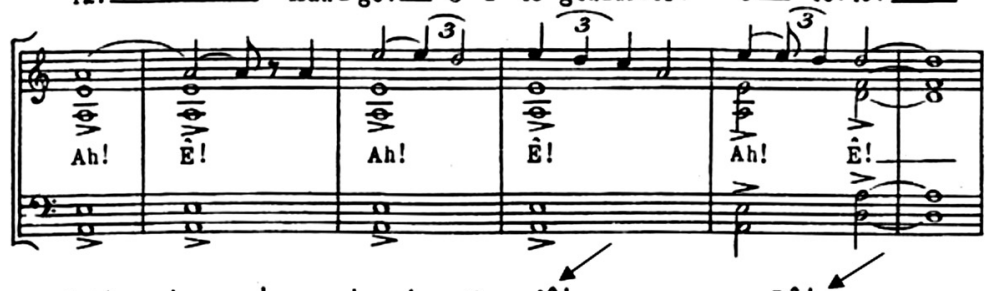

Gon! gon!_ gon! gon! gon!_ di - lê!

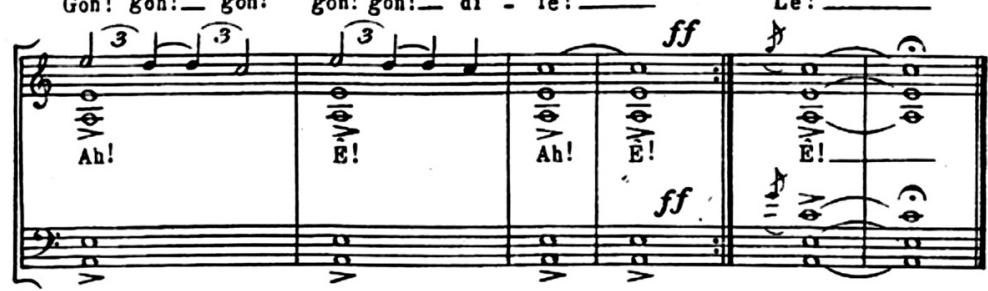

Villa-Lobos. Xangô, versão para coro a cappella, 2ํㅡ., nำ24.

Editora Irmãos Vitale, São Paulo, 1950. 


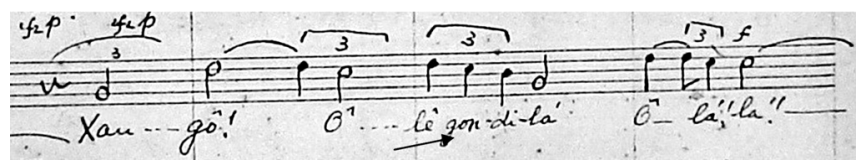

Villa-Lobos. Xangô, versão para canto e orquestra.

Biblioteca Nacional da França, Paris.

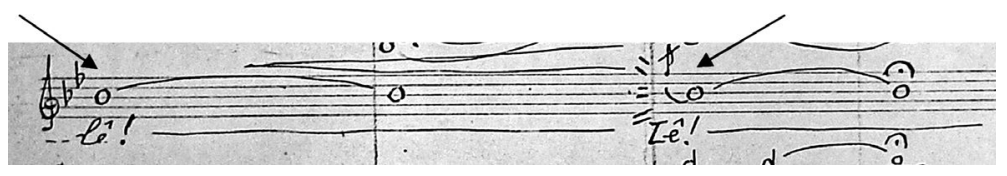

Villa-Lobos. Xangô, compassos 16-19.

Manuscrito versão orquestral,

Biblioteca Nacional da França, Paris.

Trêmolo do piano. Falta sinal de bemol na nota assinalada.

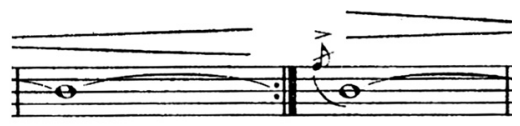

Lề!

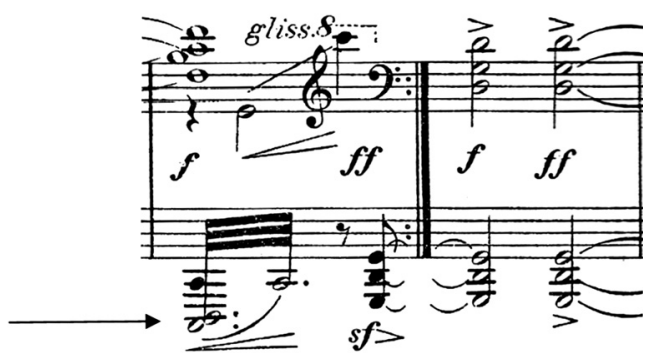

Villa-Lobos. Xangô, compasso 17.

Éditions Max Eschig, Paris, 1929. 


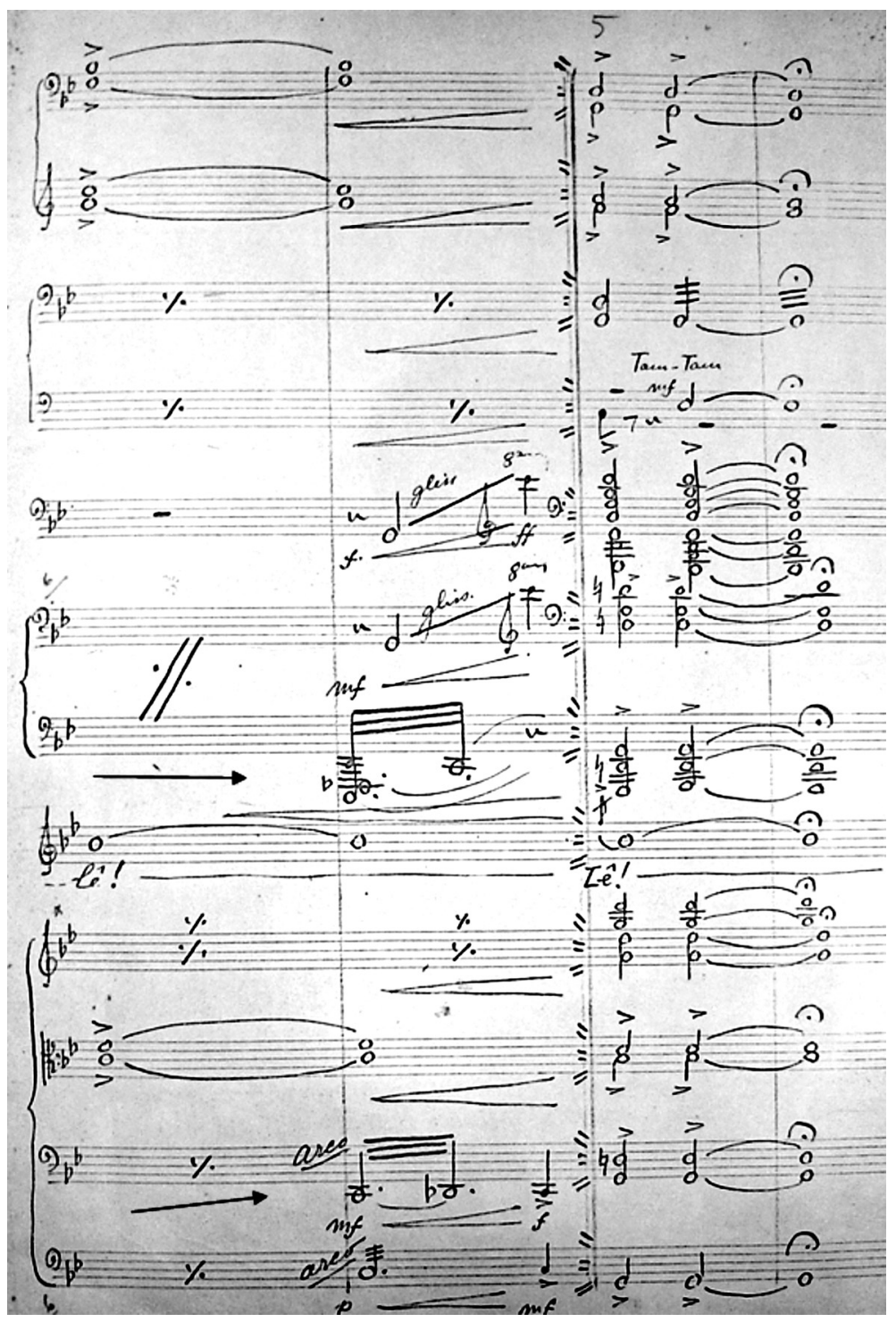

Villa-Lobos. Xangô.

Manuscrito da versão para canto e orquestra, Biblioteca Nacional da França, Paris. 


\section{Estrela é lua nova}

\section{Texto}

Canto fetiche de macumba.

Estrella é Lua Nóva

Estrella do céo é lua nova cravejada de ouro makumbêbê,

Estrela, céu

Óia makumbêbê (vocabulário afro-brasil.)

Óia makumbaribá

Estrella do céo é lua nova cravejada de ouro makumbêbê, Estrela, céu

Óia makumbêbê

Óia makumbaribá

\section{Estrutura formal e harmônica}

A canção está na tonalidade de ré maior. A segunda repetição do texto apresenta a melodia na região da dominante da subdominante (enfatizando a nota dó, sétima menor acrescentada de ré maior). Essa canção também faz parte da coleção Canto Orfeônico, 2ํำ volume, publicada em 1950 pela Irmãos Vitale, e aparece rearranjada para coro misto.

O compositor utiliza ostinatos rítmicos que evocam uma percussão típica dos rituais religiosos. O fato ocorre em todas as Canções Típicas Brasileiras baseadas em cantos indígenas ou afro-brasileiros e aparece também nas duas versões da canção Estrela é lua nova. 


\section{Aspectos interpretativos}

A seguir, sugerimos alguns dedilhados úteis:
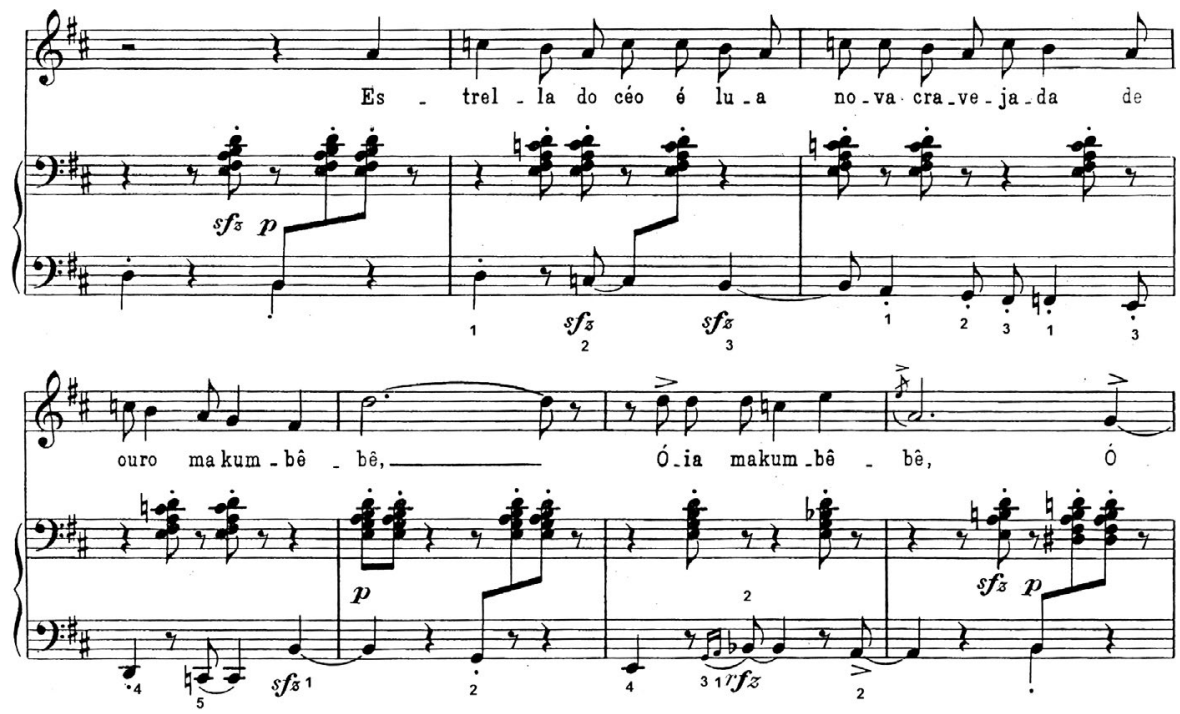

Villa-Lobos. Estrela é lua nova, dedilhados compassos 13-9, Éditions Max Eschig, Paris, 1929.

\section{Orquestração}

A canção possui versão manuscrita para voz e orquestra, que está depositada na Biblioteca Nacional da França, em Paris.

Instrumentação: voz solista, acompanhada de duas flautas, oboé, clarinete em si bemol, dois fagotes, três trompas em fá, harpa e quinteto de cordas. 


\section{Edições e manuscritos}

1. A indicação de metrônomo não consta do manuscrito da versão para voz e orquestra.

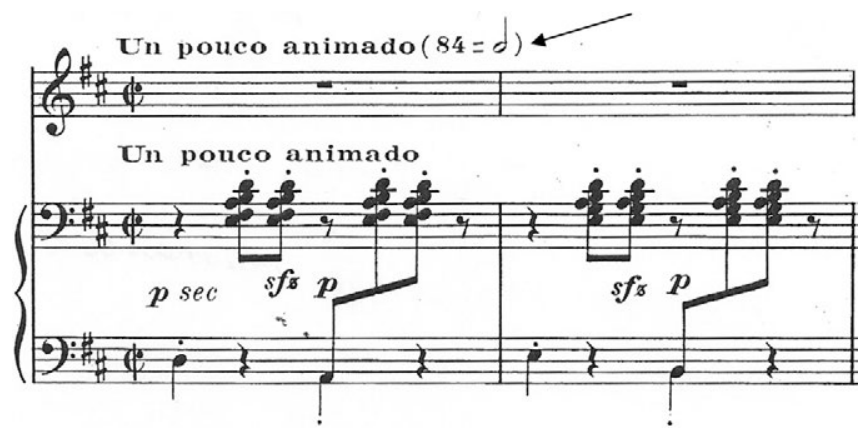

Villa-Lobos. Estrela é lua nova.

Éditions Max Eschig, Paris, 1929.

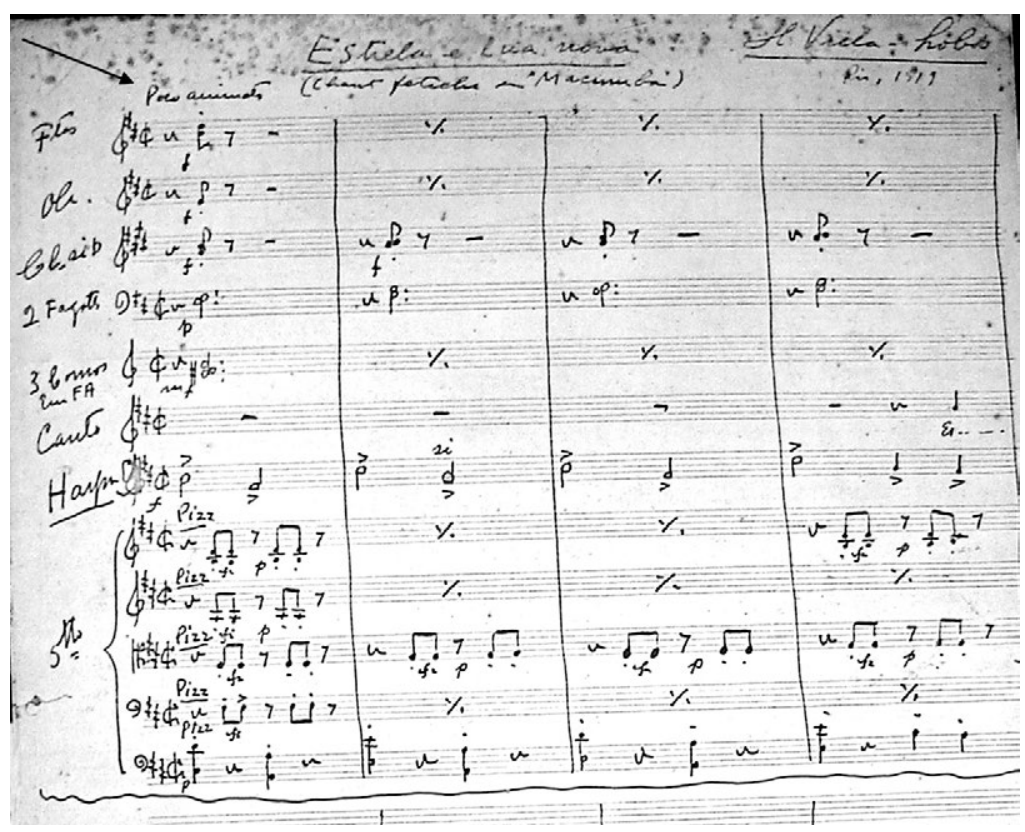

Villa-Lobos. Estrela é lua nova.

Manuscrito da versão para voz e orquestra, Biblioteca Nacional da França, Paris. 
2. Falta um sinal de $s f z$ na segunda colcheia do segundo tempo.

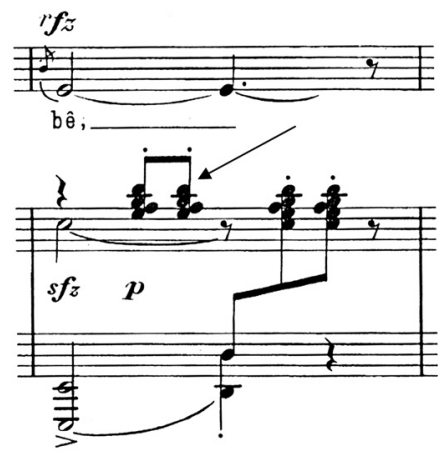

Villa-Lobos. Estrela é lua nova, compasso 8. Éditions Max Eschig, Paris, 1929.

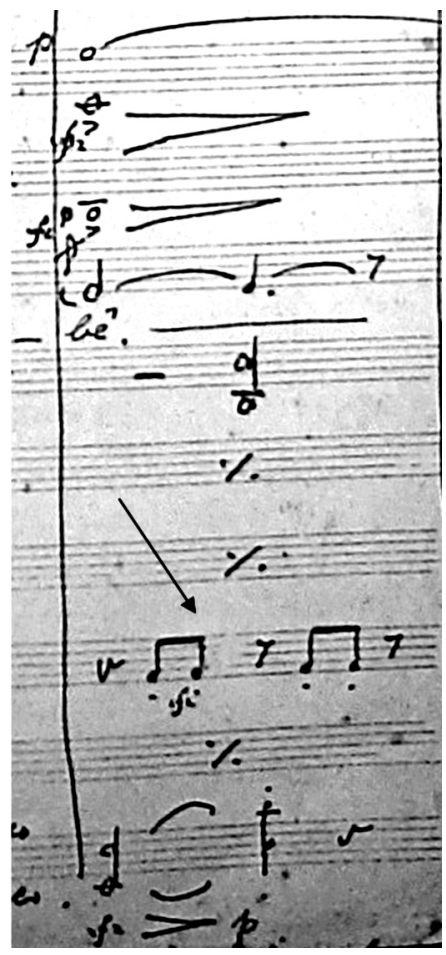

Villa-Lobos. Estrela é lua nova, compasso 8.

Manuscrito, Biblioteca Nacional da França, Paris. 
3. Falta sinal de ligadura entre o baixo do piano. Comparar o excerto com o exemplo anterior, compasso 8.

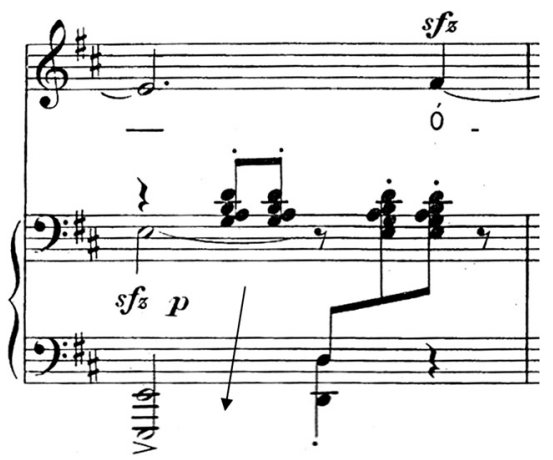

Villa-Lobos. Estrela é lua nova, compasso 10. Éditions Max Eschig, Paris, 1929.

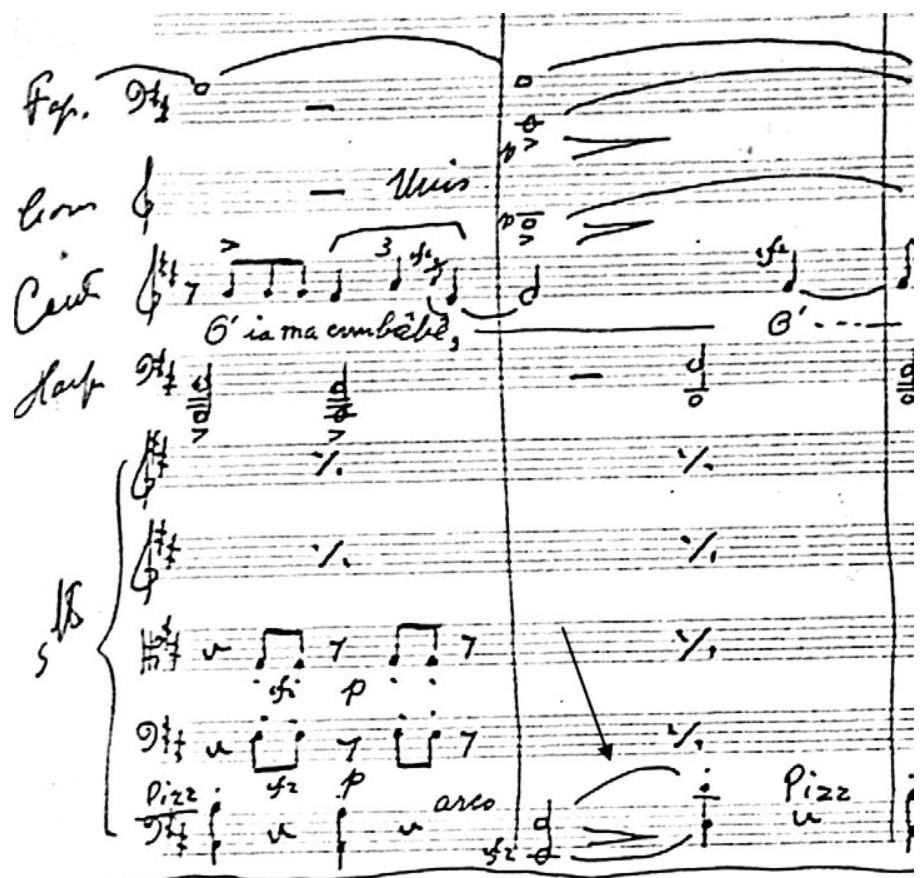

Villa-Lobos. Estrela é lua nova, compasso 10. Manuscrito, Biblioteca Nacional da França, Paris. 
4. Falta sinal de acentuação para o canto.

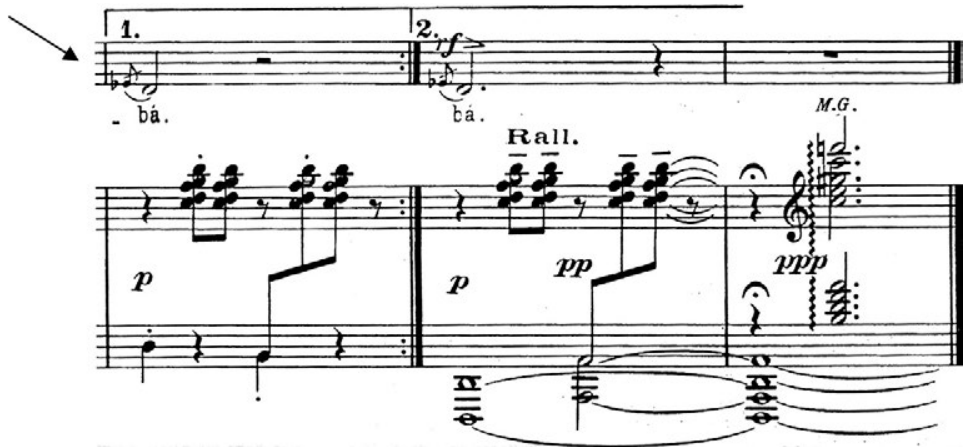

Villa-Lobos. Estrela é lua nova, compasso 21. Éditions Max Eschig, Paris, 1929.

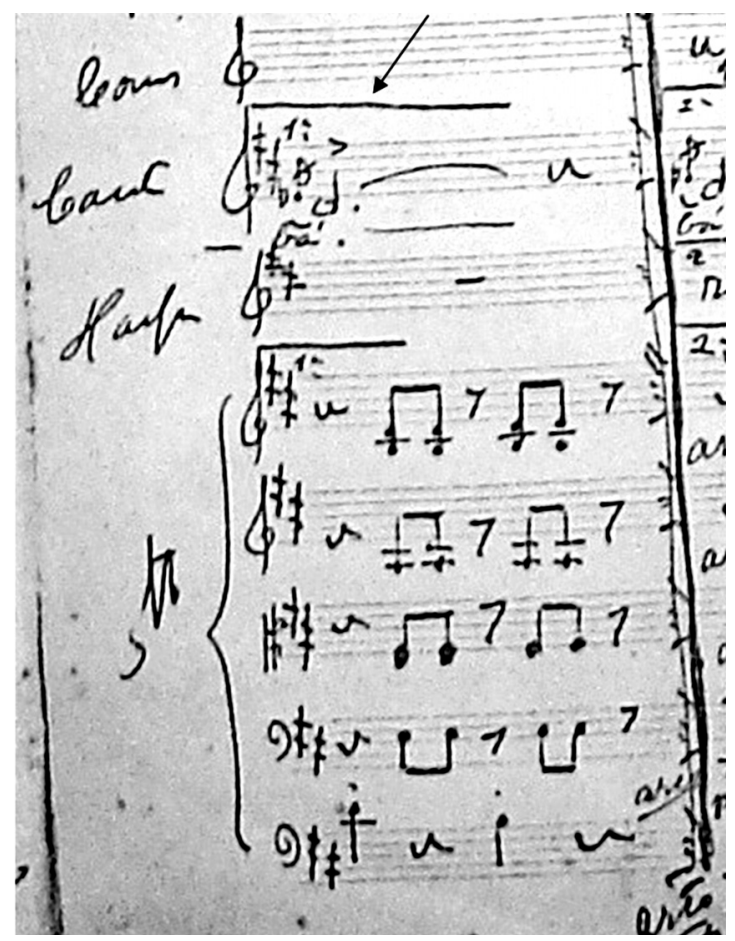

Villa-Lobos. Estrela é lua nova, compasso 21.

Manuscrito, Biblioteca Nacional da França, Paris. 


\section{Viola quebrada}

\section{Texto}

Modinha ${ }^{4}$ de M. de A. (pseudônimo de Mário de Andrade).

Por se tratar de texto popular e em linguagem caipira, os autores do início do século XX no Brasil preferiam usar pseudônimos. O mesmo M. de A. aparece em outra canção de Villa-Lobos como autor da seresta $\mathrm{n}^{\circ} 5$, intitulada Modinha, para voz e piano.

Quando da brisa no açoite a frô da noite se curvo fui s'incontrá com a Maróca meu amô

Eu tive n'arma um choque duro quando ao muro já no escuro meu oiá andô buscando a cara déla e num achô.

Minha vióla gemeu,

Meu coração estremeceu

Minha vióla quebrou

Teu coração me deixou Ah! Ah! Ah!

Minha Maróca arresorveu por gosto seu me abandoná, porque os fadista nunca sabe trabaiá,

Isso é bestêra que das frô que bria e chêra a noite intera vem apois as fruita que dá gosto saboreá.

Minha vióla gemeu,

Meu coração estremeceu

Minha vióla quebrou

Teu coração me deixou Ah! Ah! Ah!

Pur causa déla eu sou rapaiz muito capaiz de trabaiá e os dia intero, e a noite intera capiná,

Eu sei carpi purquê minh'arma está arada arroteada capinada c'oas foiçada dessa luis do teu oiá.

4 Segundo o Dicionário Aulete de língua portuguesa, modinha é uma cantiga popular urbana, sentimental, acompanhada por violão; moda, até meados do século XIX, era um tipo de dança aristocrática de salão, que na forma se inspirava na ária de óperas italianas. 
Minha vióla gemeu,

Meu coração estremeceu

Minha vióla quebrou

Teu coração me deixou Ah! Ah! Ah!

\section{Estrutura formal e harmônica}

Estrutura: canção com estribilho (Chanson Couplet-Refrain)

Seção A1 - piano solo (compassos 1 a 9) seguido pelo 1ํv verso voz e piano (compassos 9 a 17).

Acompanhamento no estilo seresteiro, com a mão esquerda do pianista imitando os baixos do violão. Segundo Tarasti (idem, p.225), em Viola quebrada há "uma transformação do piano em uma guitarra".

Seção B (estribilho) - acompanhamento em estilo coral, organístico (com parte de coro ad libitum).

Seção A2 - piano solo seguido pelo $2^{\circ}$ verso - voz e piano.

Seção B (estribilho) - Acompanhamento em estilo coral, organístico (com parte de coro ad libitum).

Seção A3 - piano solo seguido pelo 3ํ verso - voz e piano.

Seção B (estribilho) - Acompanhamento em estilo coral, organístico (com parte de coro ad libitum).

Tonalidade: mi menor.

\section{Aspectos interpretativos}

Nessa canção encontramos problemas de fraseado e respiração do cantor que deverá ser acompanhado pelo pianista. Por não haver indicação de fraseado para a linha melódica do canto, sugerimos um fraseado baseado no ritmo da poesia.

No estribilho encontramos uma frase musical muito clara, a cada linha do texto. Não há dúvidas quanto à sua articulação, pois cada frase termina com uma nota musical de duração longa, na qual obviamente se colocará a respiração adequada. Assim, vamos nos ocupar dos três versos que têm ritmos semânticos e poéticos diferentes. 


\section{1을 verso:}
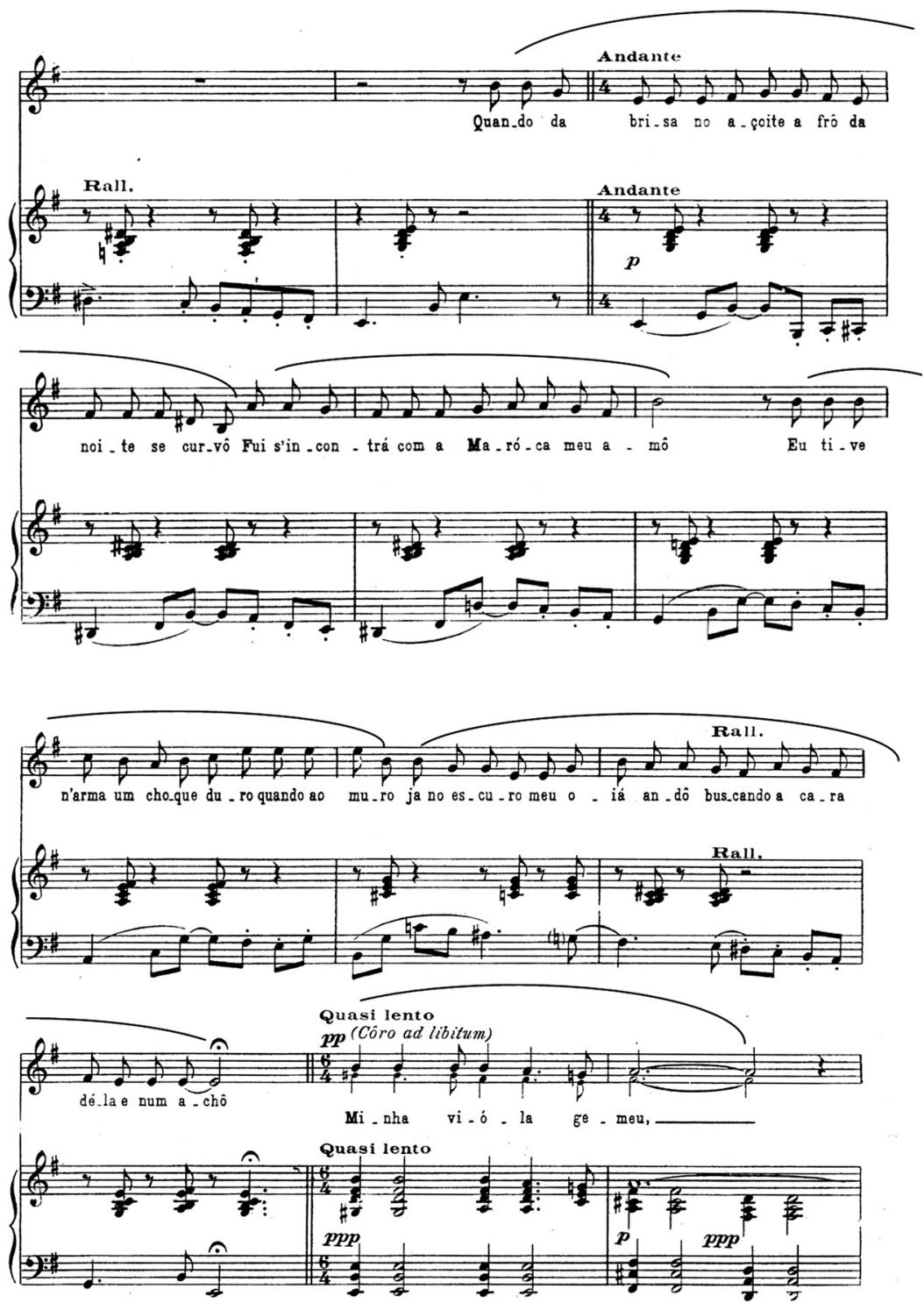

Villa-Lobos. Viola quebrada, 1ำ verso.

Éditions Max Eschig, Paris, 1929. 
2으 verso:
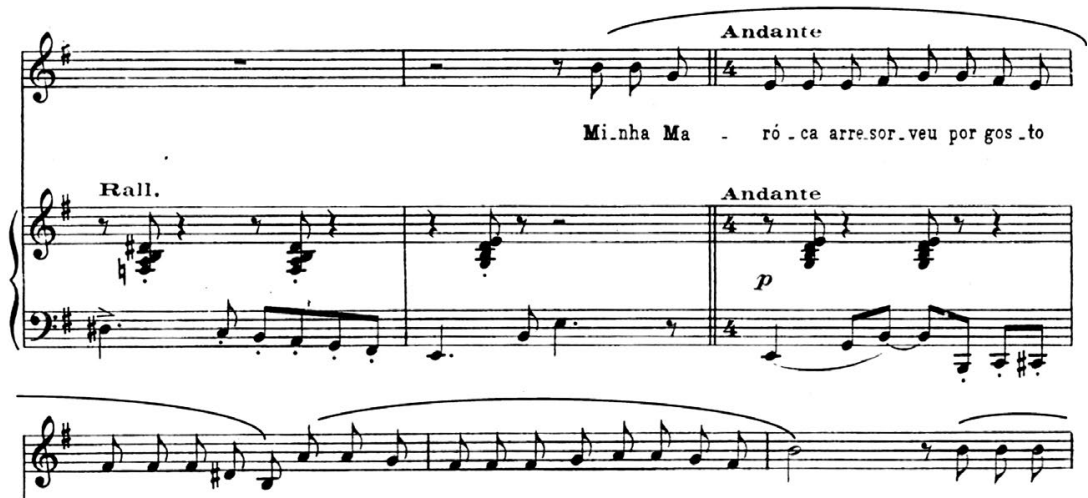

seume a_ban_do - ná,Porque os fa - dis ta nun - ca sa - be tra - ba - iá,
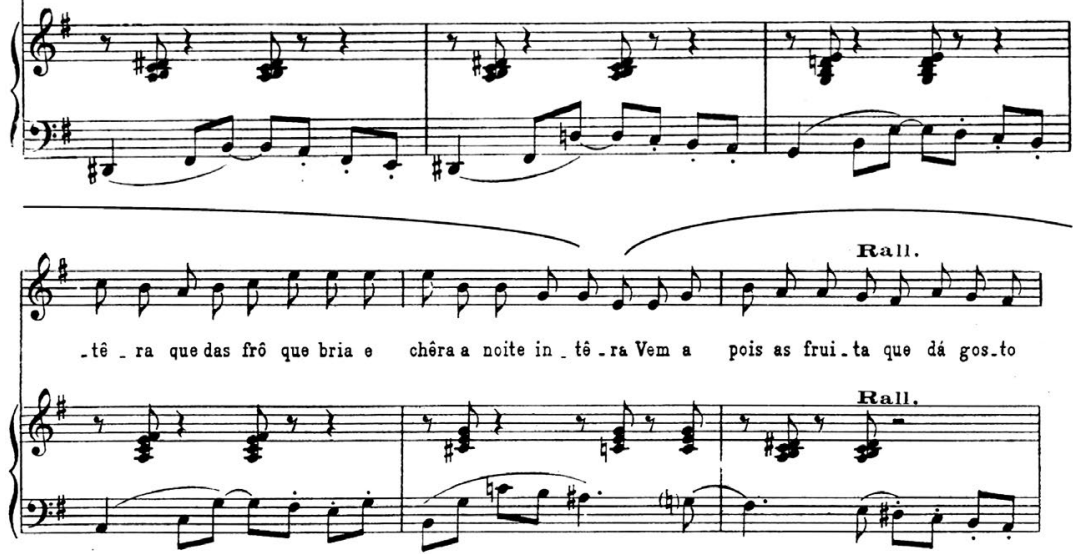

uasi lento
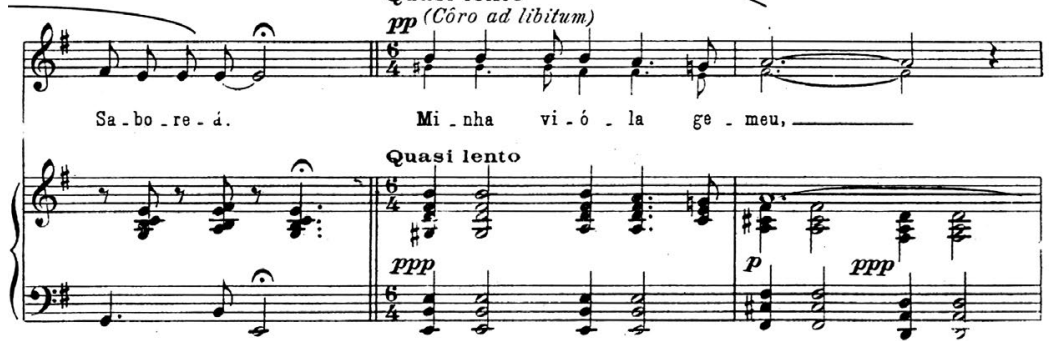

Villa-Lobos. Viola quebrada, 2o verso.

Éditions Max Eschig, Paris, 1929. 
3ํㅡㄹㅗ:
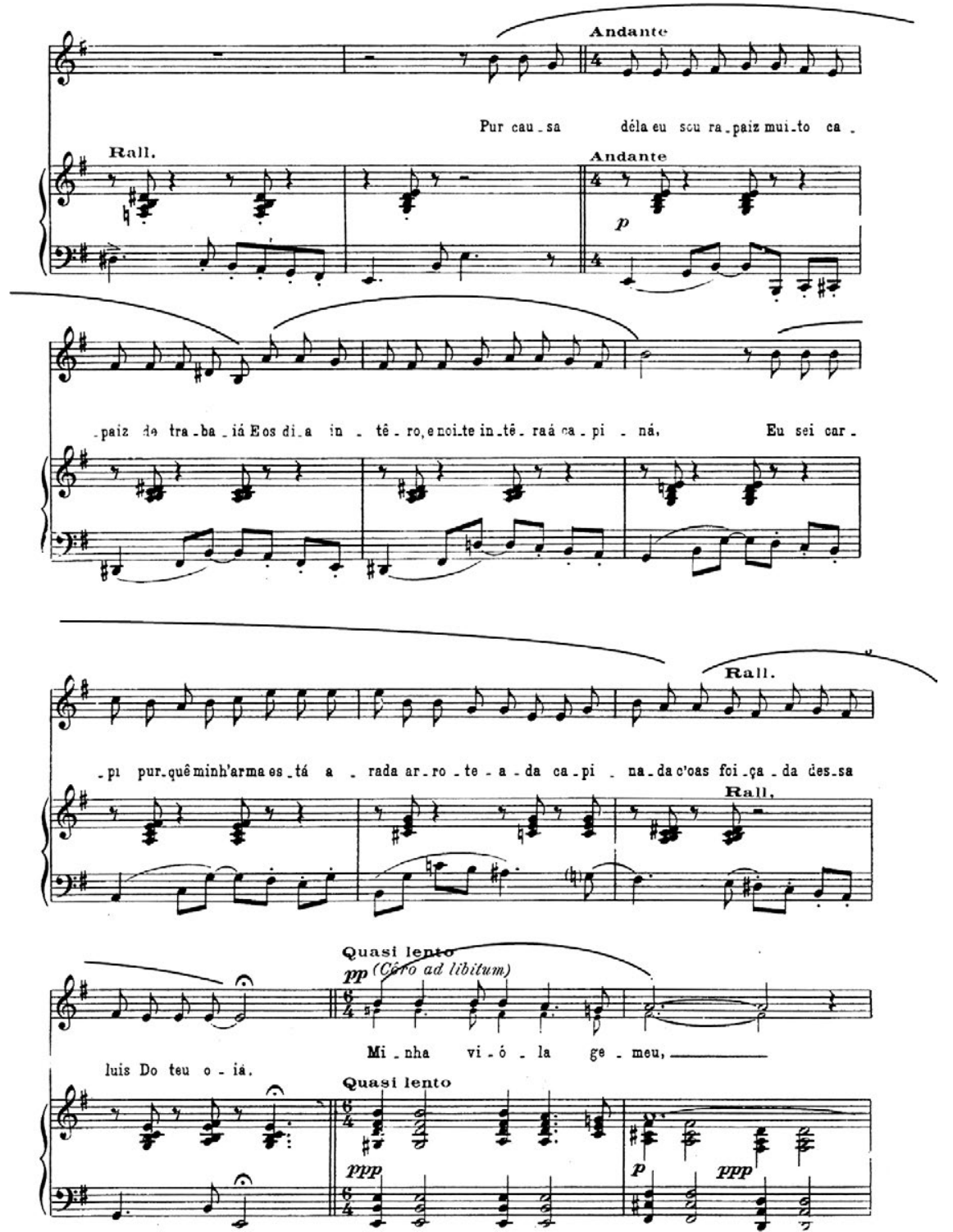

Villa-Lobos. Viola quebrada, 3ำ verso.

Éditions Max Eschig, Paris, 1929. 


\section{Edição e manuscrito}

A canção foi publicada pela Max Eschig e seu manuscrito está desaparecido. Não há erros aparentes na partitura.

\section{Adeus Ema}

Desafio. ${ }^{5}$ Tema popular do estado de Minas Gerais, Brasil.

\section{Texto}

Adeus Ema, adeus Ema

Dali cença eu vou fallá dá licença (ver verso abaixo)

Os nome na minha terra É diferente dos de cá.

Adeus Ema, adeus Ema uma amostra quéro dá Tabóca não é tabóca que a gente faz gaita e tóca Tabóca é bocatá.

Adeus Ema, adeus Ema

Vancê faz bem me assuntá

De tudo que eu vou dizê

Vancê só pode é lucrá.

Adeus Ema, adeus Ema, Barata é rataba, Maria não é Maria, Mãe de Deus e de Deus fia, Maria é riamá

Adeus Ema, adeus Ema

Dá licença eu vou fallá

Nós já contamo que chega

Por isso vamo pará.

5 Desafio, segundo o Dicionário Aulete da língua portuguesa, é a disputa musical em que dois cantadores se alternam com versos improvisados. 
Não realizamos nenhuma mudança no texto por se tratar de texto regionalista, que traz propositadamente vários erros de concordância. Sugerimos somente uma pequena mudança por se tratar de erro editorial evidente.

\section{Estrutura formal e harmônica}

Como em várias canções baseadas em temas folclóricos, VillaLobos compõe um ostinato para o acompanhamento que se desenvolve à maneira da música popular, quase sem alterações harmônicas.

A tonalidade é dó maior e o acompanhamento é construído sempre a partir de acordes de tônica e dominante com sexta acrescentada. A seção A, compassos 3 a 13, é repetida três vezes mudando o texto.

\section{Edição e manuscrito}

Não há manuscritos disponíveis dessa canção. Anotaram-se algumas reflexões sem a intenção de corrigir a partitura, mas sim de interpretar os sinais nela existentes.

Notamos, por exemplo, que alguns sinais de acentuação têm uma recorrência irregular, apesar da grande regularidade do ostinato. Segundo Elias (1995, p.255), "de todos os equívocos que uma escritura pode suscitar, uma das mais nocivas à obra de Villa-Lobos é o emprego errôneo dos acentos". Segundo a autora, "as acentuações devem dar relevo à melodia e não prejudicar o fluxo melódico da frase".

No entanto, esses sinais intermitentes podem ser uma sugestão de improvisação do compositor no parâmetro das acentuações. Podem significar um contraponto rítmico à regularidade métrica e harmônica. Como exemplo, podemos interpretar os vários acentos do compasso 13 como um crescendo antes da reprise do tema, que deverá ser imediatamente seguido por um piano súbito, que também não aparece anotado. 


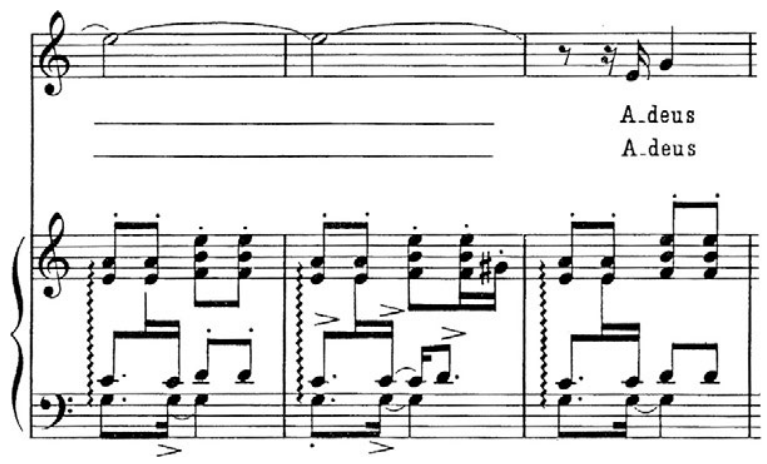

Villa-Lobos. Adeus Ema, compasso 13.

Éditions Max Eschig, Paris, 1930.

No compasso 24, tais acentos poderiam significar uma reação musical à finalização da estrofe do cantor, o que seria um procedimento característico do desafio popular:
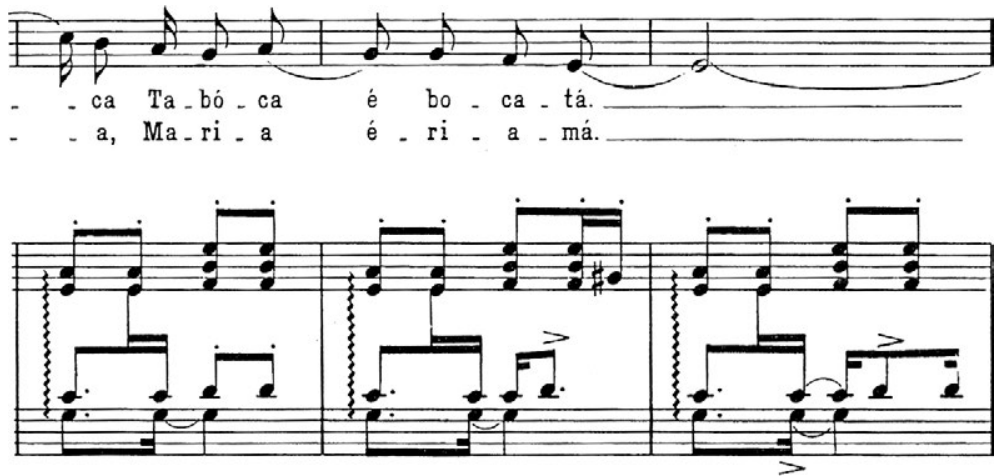

Villa-Lobos. Adeus Ema, compasso 24.

Éditions Max Eschig, Paris, 1930.

2. No compasso assinalado trata-se provavelmente de um erro de notação.

A nota do soprano no piano é mi e não ré. Justificativa: excetuando os compassos com harmonia predominante de dominante (nos quais temos o intervalo de quinta sol - ré no baixo, primeiro tempo 
do compasso, como nos compassos 6, 7 e 8), podemos contar 26 vezes esse mesmo motivo repetido. Apesar de cabível na configuração harmônica, é muito pouco provável que somente nesse compasso Villa-Lobos quisesse mudar a condução musical.

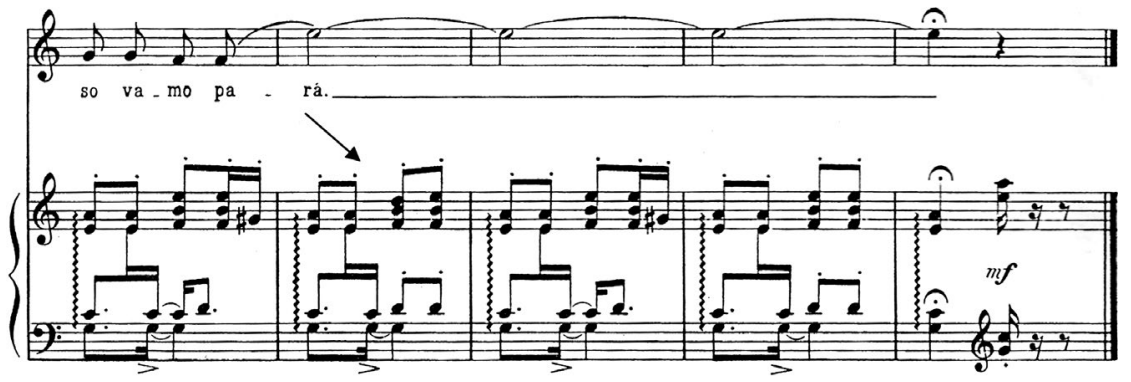

Villa-Lobos. Adeus Ema, compassos finais.

Éditions Max Eschig, Paris, 1930.

\section{Pálida Madona}

Modinha antiga.

\section{Texto (poesia popular)}

Ó pálida Madona de meus sonhos, bela filha dos cerros de Enggandi. ${ }^{6}$

Vem inspirar os cantos do poéta, rósa branca da Lyra de David poeta, rosa

Vem inspirar os cantos do poéta, rósa branca da Lyra de David Rósa branca da Lyra de David.

Todo o amor que em meu peito repousava, como o orvalho das noites no relento,

A teus pés elevou-se como as nuvens, que se perdem no azul do firmamento!

6 Enggandi era uma antiga cidade da Judeia. Há uma região de mesmo nome perto da cidade de Natal, capital do estado do Rio Grande do Norte, Brasil. 
A teus pés elevou-se como as nuvens, que se perdem no azul do firmamento!

Que se perdem no azul do firmamento!

\section{Estrutura formal e harmônica}

Tonalidade: dó menor.

Seção A. Lento - Adagio, compassos 1 a 8.

Tema instrumental no piano nos compassos 1 a 4 seguido pela melodia vocal parlando, que vem acompanhada muito discretamente pelo piano.

Seção B. Poco più mosso, compassos 9 a 18.

Desvio para a região da dominante da relativa maior - si bemol maior. No compasso 15 há um novo direcionamento para dó menor.

Acompanhamento instrumental mais movido, caracterizando o estilo de acompanhamento característico da modinha, que vem evocada no título da canção.

Compassos 18 a 21: volta do tema instrumental do piano apresentado nos compassos 1 a 4 . O tema instrumental de abertura também funciona como coda da canção, após a repetição das Seções A e B com novo texto.

\section{Aspectos interpretativos}

A seguir, sugerimos alguns dedilhados úteis para a introdução do piano:

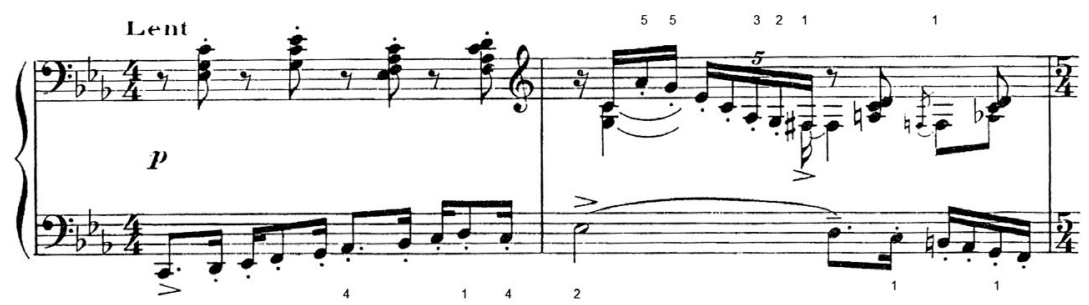

Villa-Lobos. Pálida Madona, compassos 1-2.

Éditions Max Eschig, Paris, 1930. 


\section{Edição e manuscrito}

1. Erro de edição. Por analogia entre as partes idênticas, podemos concluir que esse é um erro evidente de edição.

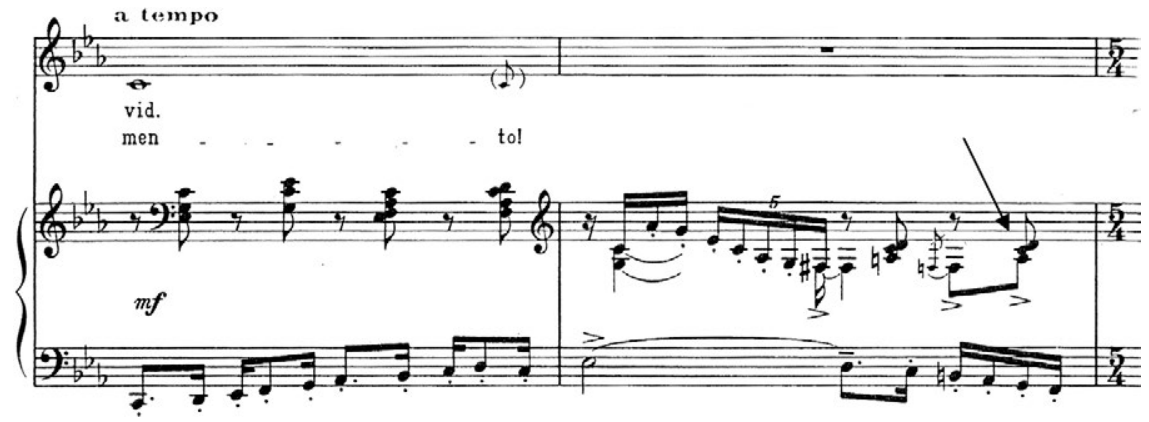

Villa-Lobos. Pálida Madona, compassos 18-9.

Éditions Max Eschig, Paris, 1930.

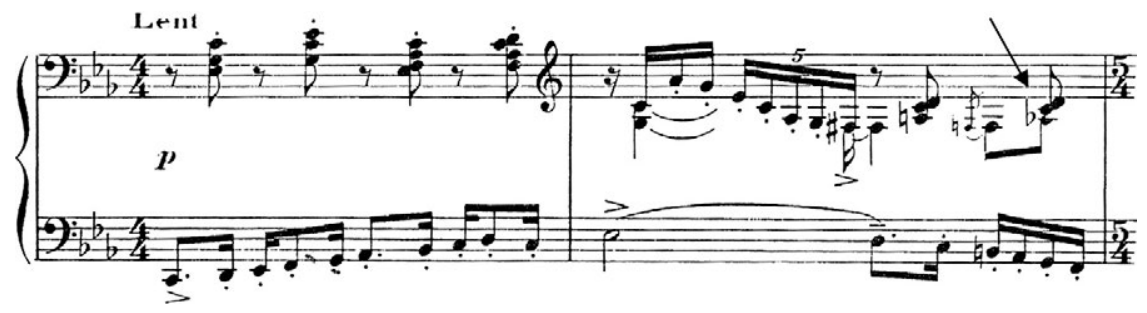

Villa-Lobos. Pálida Madona, compassos 1-2.

Éditions Max Eschig, Paris, 1930

2. Provável erro de edição. No compasso 12 na mão esquerda do pianista há um possível erro de edição, baseado na análise do movimento que se desenvolve na linha melódica do baixo no piano. 

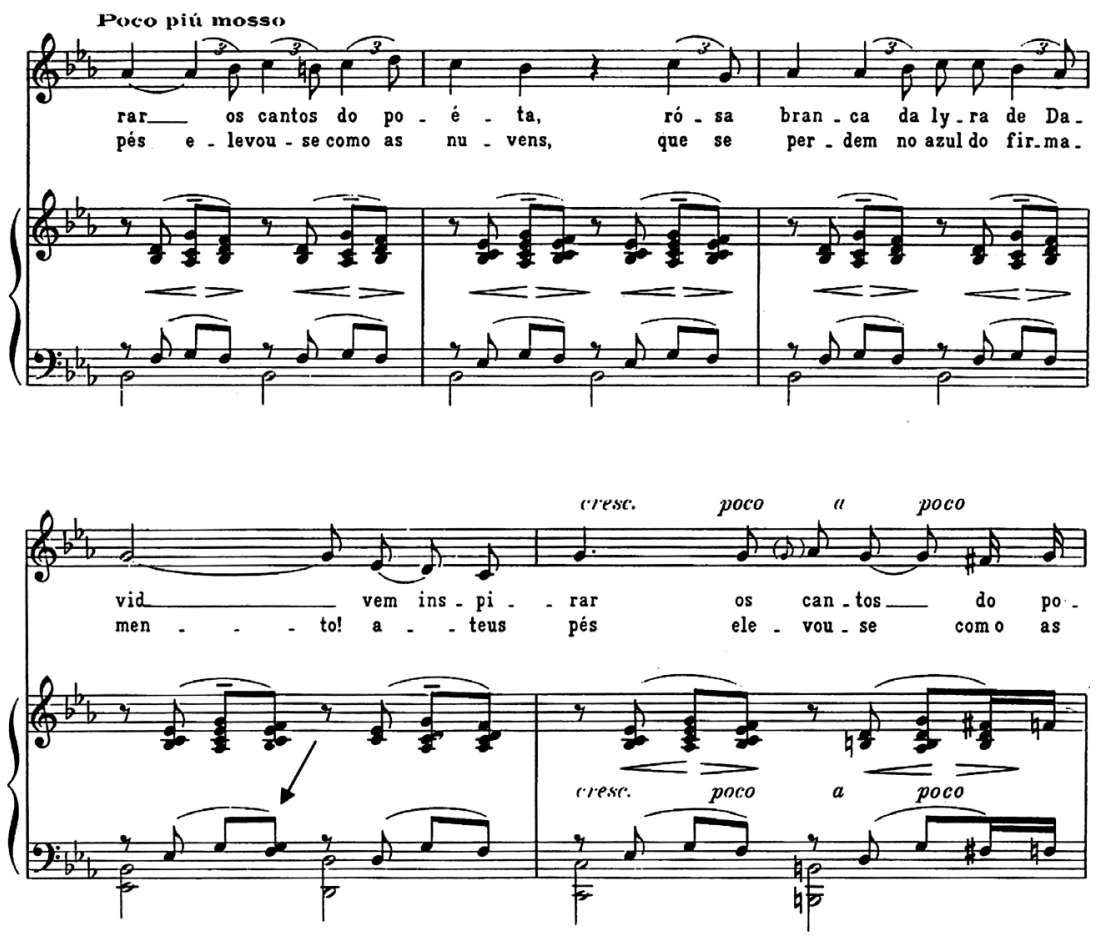

Villa-Lobos. Pálida Madona, compassos 9-13.

Éditions Max Eschig, Paris, 1930.

\section{Tu passaste por este jardim}

Modinha carioca.

\section{Texto}

\section{Autor: Catullo Cearense}

Como assinalado anteriormente, a correção ortográfica do texto foi realizada para adequar a poesia à moderna nomenclatura da língua portuguesa e para ajudar um intérprete não familiarizado com a língua a encontrar o significado das palavras atualizadas. Cada cantor escolherá o caminho que melhor lhe convier seguir na emissão e na interpretação das palavras. 


\section{Seção}

Tu passaste por este jardim

\section{A}

Sinto aqui certo odôr merencoreo.

odor, merencório

Este branco e donoso jasmim

N'um dilúvio de aromas pendeu

Os archanjos choraram por mim, arcanjos sobre as folhas pendentes do galho, as estrellas cadentes do orvalho que a luz de seus olhos, estrelas brilhantes verteu.

Esta relva, que vejo a murchar, e onde, penso, cahiu o teu lenço, caiu transformou-se depois n'um altar, exhalando alleluias de incenso. exalando, aleluias Muita cousa tu deixaste aqui coisa N'este orgulho das auras mimosas:

Um barulho de folhas cheirosas de plantas saudosas, falando de ti.

\section{Seção B}

Tu passaste, que, de quando em quando, vejo as rosas no hastil lacrimando das corollas de todas as côres corolas, cores as minhas angústias abertas em flôres! flores

Neste ramo, que ainda se agita, uma roxa saudade palpita!

E este cravo, no ardor dos ciúmes, derrama os perfumes n'um poêma de amor.

poema

De um suspiro, deixaste o calor A

n'este calix de neve, estrellado! cálice, estrelado N'este branco e gentil "monselhor" vê-se o Iris de um beijo, esmaltado Tu deixaste, n'um halo de dor, nas violetas magoadas sombrias, 
a tristeza das Ave-Marias que résam teus lábios,

rezam a luz do Senhor.

Vejo a imagem da minha illuzão ilusão

C

N'esta rósa prostrada no chão! rosa, prostrada

Meus affectos descansam nos leitos afetos

D'estes lindos amores perfeitos

Como chora o vernal jasmineiro,

Que me lembra o sabor de teu cheiro!

Este cravo sanguines é uma chaga, sanguíneo que se alaga no rubor da cor.

As gentis magnólias, em vão,

A

muito invejam teu rosto odoroso, rosto que tem conformação de um suspiro adejando saudoso.

E estes lírios têm a presumpção de imitar, presunção em seus níveos brancores, Esses dous ramalhetes de amôres, dois, amores andores de flores n' um seio em botão.

\section{Estrutura formal e harmônica}

Canção em forma de rondó.

Introdução do piano. Très Peu Moderé, compassos 1 a 4. Seção A: Moderé, compassos 5 a 20. Tonalidade: fá maior. Seção B: compassos 21 a 28. Tonalidade da dominante: dó maior. Seção A: 29 a 44. Tonalidade: fá maior.

Seção C: 45 a 52. Tonalidade da subdominante: si bemol maior/ sol menor.

Seção A: compassos 53 a 69. Tonalidade: fá maior.

\section{Edição e manuscrito}

O manuscrito dessa canção está desaparecido. No entanto podemos encontrar alguns erros prováveis da edição, mencionados a seguir. 
1. A seção A aparece idêntica três vezes ao longo da canção. Assim, podemos inferir que as pequenas diferenças entre elas podem configurar um erro de edição.

Nos compassos 5 e 6 não há sinais de staccato nos acordes da mão direita.

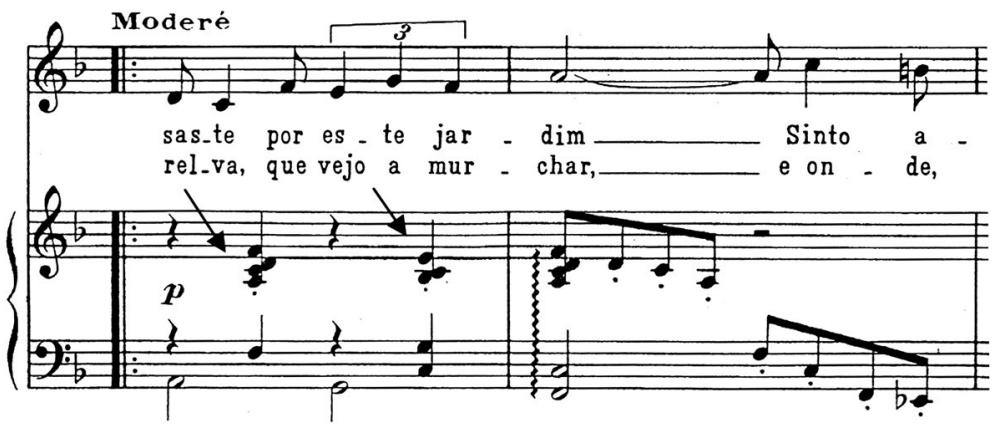

Villa-Lobos. Tu passaste por este jardim, compassos 5-6. Éditions Max Eschig, Paris, 1930.

Compasso 30: a nota do soprano do acorde da mão direita é fá e não lá. A nota lá triplicaria a terça do acorde, duplicaria a nota do canto e endureceria a harmonia por meio de um uníssono oculto e reforçaria por demais seu caráter maior/menor.

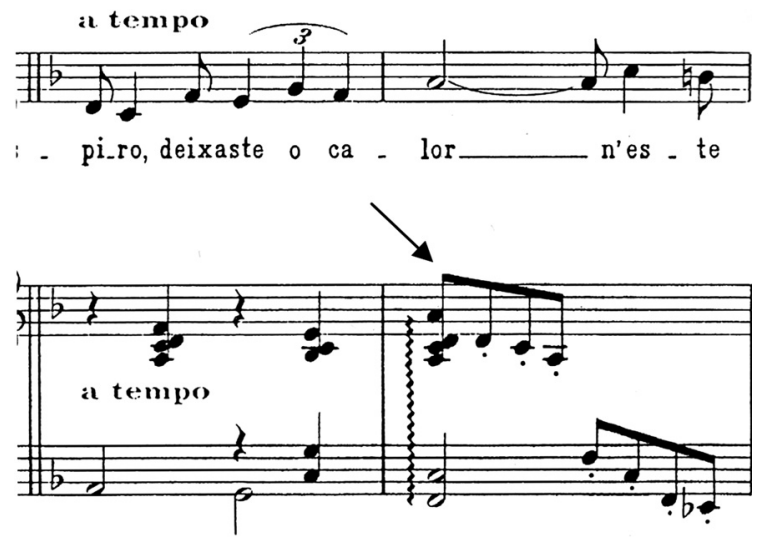

Villa-Lobos. Tu passaste por este jardim, compassos 29-30. Éditions Max Eschig, Paris, 1930. 
Compasso 37: o acorde da mão direita foi omitido.

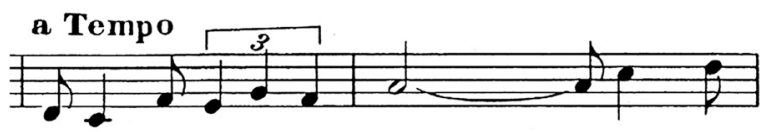

- xaste, n'um ha_lo de dor,_ nas vio

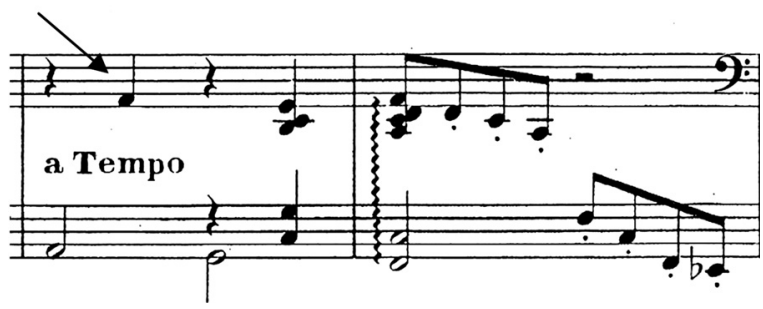

Villa-Lobos. Tu passaste por este jardim, compassos 37-8. Éditions Max Eschig, Paris, 1930.

Compassos 53 e 54: versão aparentemente correta.

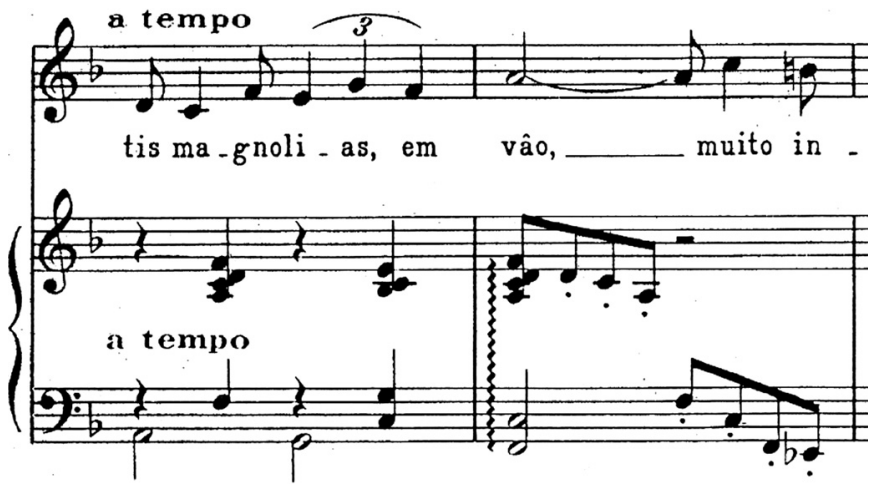

Villa-Lobos. Tu passaste por este jardim, compassos 53-4. Éditions Max Eschig, Paris, 1930.

\section{Cabôca de Caxangá}

Para canto a 4 vozes e coro misto.

Embolada do Noste (erro Max Eschig). O correto é Embolada do Norte (Norte do Brasil). 


\section{Texto}

Autor: Catullo Cearense.

Texto regionalista com linguagem típica do Norte do país. Correções linguísticas não são cabíveis nesse contexto específico.

Cabôca de Caxangá minha cabôca vem cá.

A coro

Cabôca de Caxangá minha cabôca vem cá.

Laurindo, Punga, Dunga, Zé Vicente,

B tenor essa gente tão valente do sertão de Jatobá i o damnado do afamado do Zéca Lima, tudo chora n'uma prima, tudo qué ti conquistá.

Cabôca de Caxangá minha cabôca vem cá.

A coro Cabôca de Caxangá minha cabôca vem cá.

Quiria vê si essa gente também sente tanto amô como eu sinti,

B tenor

quanto tivi em Cariri!

Atravessava um regato no quartáo e escutava lá no matto o canto triste do urutáo.

Cabôca, demônio máo, sou triste como o urutáo!

A coro Cabôca, demônio máo, sou triste como o urutáo!

Há munto tempo lá nas moita das taquara

B soprano+contralto juncto ao monte das coivara, não te vejo tu passá!

Todos os dia, inté a bocca da noite, eu te canto uma toada lá debaixo do indayá.

Vem cá Cabôca, vem cá rainha de Caxangá

A coro Vem cá Cabôca, vem cá rainha de Caxangá

Na noite santa do natá na encruziada,

\section{B soprano+contralto+tenor}

eu ti isperei i discantei inté o rompê da manhã!

Quando eu sahia do arraia, o só nacia i lá na grota já se ouvia a pipiando a jassanã. 
Cabóca frô da manhã, sou triste como a acauã!

A coro

Cabóca frô da manhã, sou triste como a acauã!

Vinha trotanto pela estrada na mujica

B soprano

Vite embaixo da oiticica conversando com o Manoél.

Sinti, Cabôca, istrimecê, dentro do couro arreliado, atrapaiado, o coração do meu quicé.

Cabôca, inda tenho fé de fazê figa ao Manoé!

A coro

Cabôca, inda tenho fé de fazê figa ao Manoé!

Cabra damnada do assubo pela gamelera,

\section{B soprano+contralto + tenor + baixo}

como a onça mais matrera, o mais ligeiro punagê!

Eu faço tudo só não faço é mi querê

teu coração mais buliçoso do que o saci pererê!

Pruquê te fez Deus, pruquê da cô das frô dos ipê!

A coro

Pruquê te fez Deus, pruquê da cô das frô dos ipê!

Mas quando eu canto na vióla a natureza,

B soprano

tu não vê como a tristeza, me põe triste e jururu!

Assim eu canto a minha dô, só quando a noite vem fechá todas as frô i abre a frô do imbirussú.

Cabôca, um demônio és tu! ó frô do embirussú.

A coro

Cabôca, um demônio és tu! ó frô do embirussú.

\section{Estrutura formal e harmônica}

De acordo com Tarasti (1995, p.225), o mesmo tema de Cabôca de Caxangá foi usado por Darius Milhaud no ballet Le boeuf sur le toit, op. 58 (1919).

Canção popular de estrutura simples baseada em estribilho e refrão.

Chanson Couplet-Refrain

Seção A é cantada pelo coro. Un peu moderé.

Na última apresentação de A, há um divisi em $7 / 8$ vozes, com indicação de mudança de caráter: largo e grandeoso. 
Seção B é a seção solista.

1 tenor

2 tenor

3 soprano e contralto

4 soprano, contralto e tenor

5 soprano

6 soprano, contralto tenor e baixo

Tonalidade sol maior, baseada em acordes de tônica e dominante.

\section{Aspectos interpretativos}

Sugerimos abaixo alguns dedilhados que poderão ser úteis para o pianista.
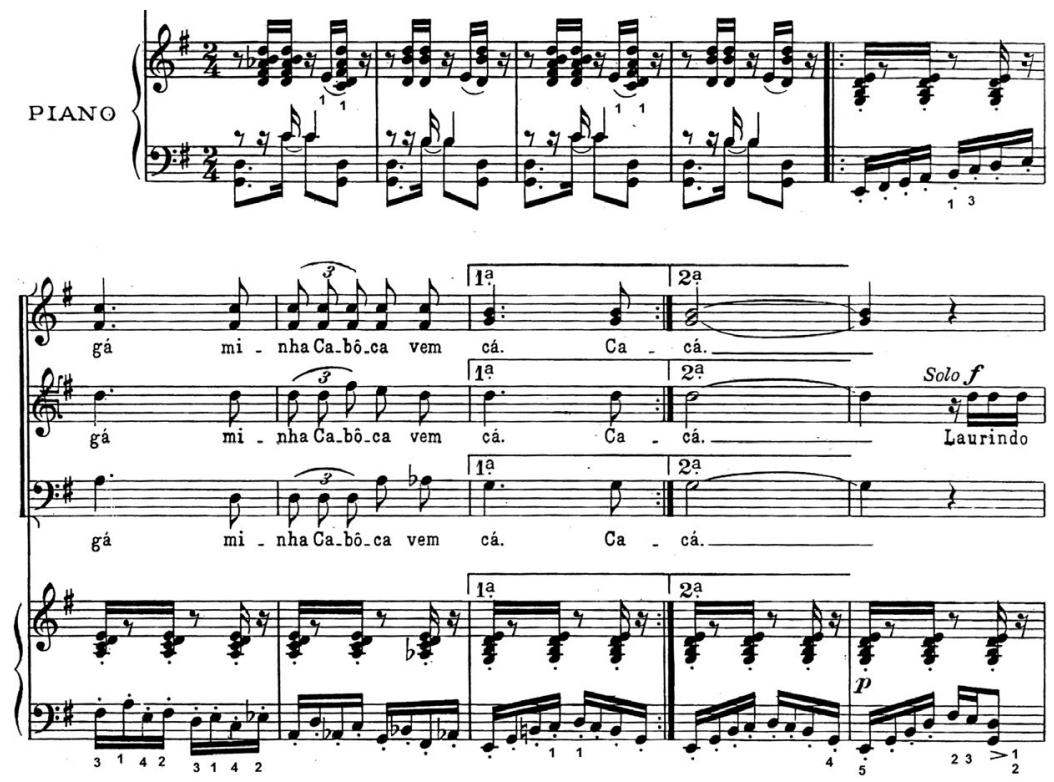

Villa-Lobos. Cabôca de Caxangá, compassos 1-10. Éditions Max Eschig, Paris, 1930.

\section{Edição e manuscrito}

Não há manuscrito disponível para análise. Existem alguns prováveis enganos na edição, possíveis de verificar pela recorrência das seções. 
Não é raro encontrarmos em Villa-Lobos mudanças em algumas notas durante o discurso musical para obter diversidade de expressão. Assim, tomou-se o cuidado de indicar em alguns dos casos onde parece haver, de fato, um engano de notação.

1. A última semicolcheia do baixo é sol e não lá. A nota sol aparece seis vezes a cada repetição de A. Trata-se de um claro engano de edição.
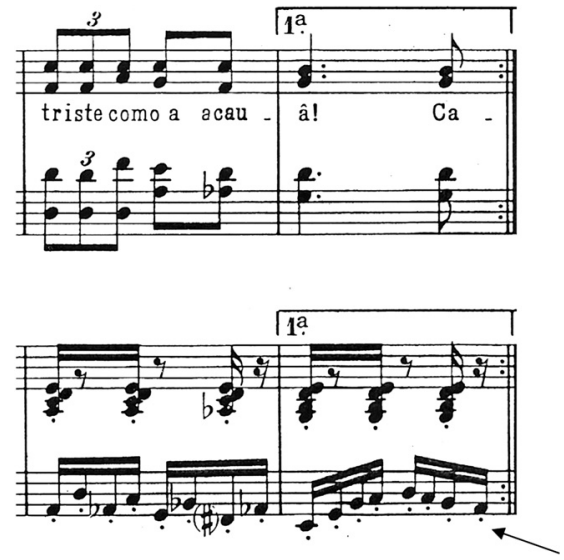

Villa-Lobos. Cabôca de Caxangá, compasso 59.

Éditions Max Eschig, Paris, 1930.
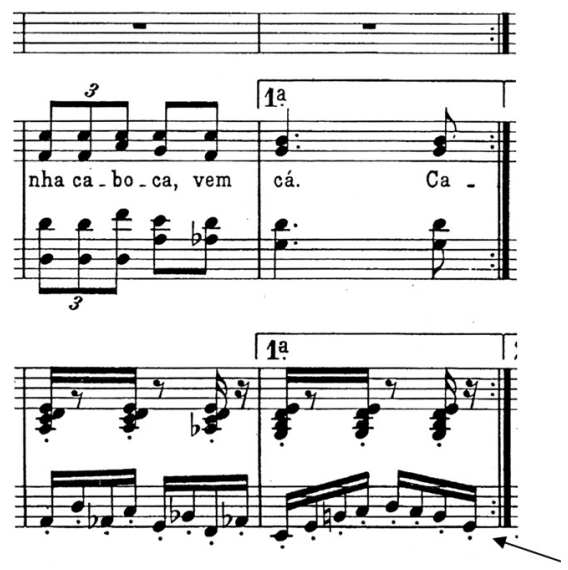

Villa-Lobos. Cabôca de Caxangá, compassos 8, 21, 47, 72 e 85.

Éditions Max Eschig, Paris, 1930. 
2. No compasso 13, o lá bemolé provavelmente um lá bequadro. O mesmo desenho cromático lá bemol - lá bequadro acontece mais três vezes, nos compassos 24-25, 62-63 e 88-89. A esse fato, soma-se o fato de o lá cantado pelo tenor ser também bequadro.

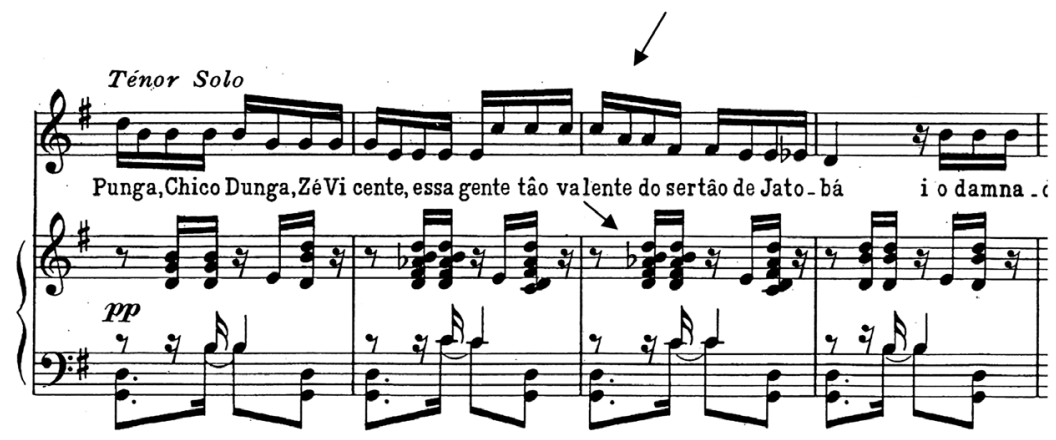

Villa-Lobos. Cabôca de Caxangá, compassos 10-4. Éditions Max Eschig, Paris, 1930.

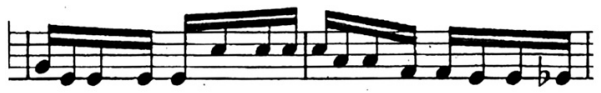

ujica Vite embaixo da oiticica conversando com o Man

Ténors Div: á boucheft
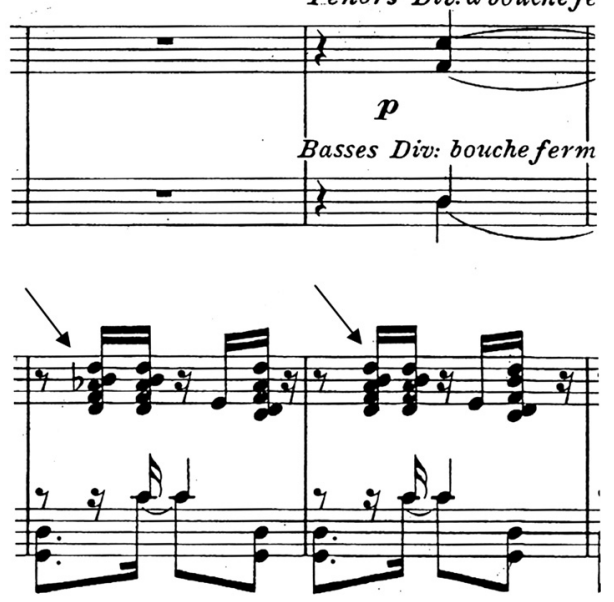

Villa-Lobos. Cabôca de Caxangá, compassos 62-3. Éditions Max Eschig, Paris, 1930. 
XI. Pássaro fugitivo (1935) ou Guriatã de coqueiro

Manuscrito não editado.
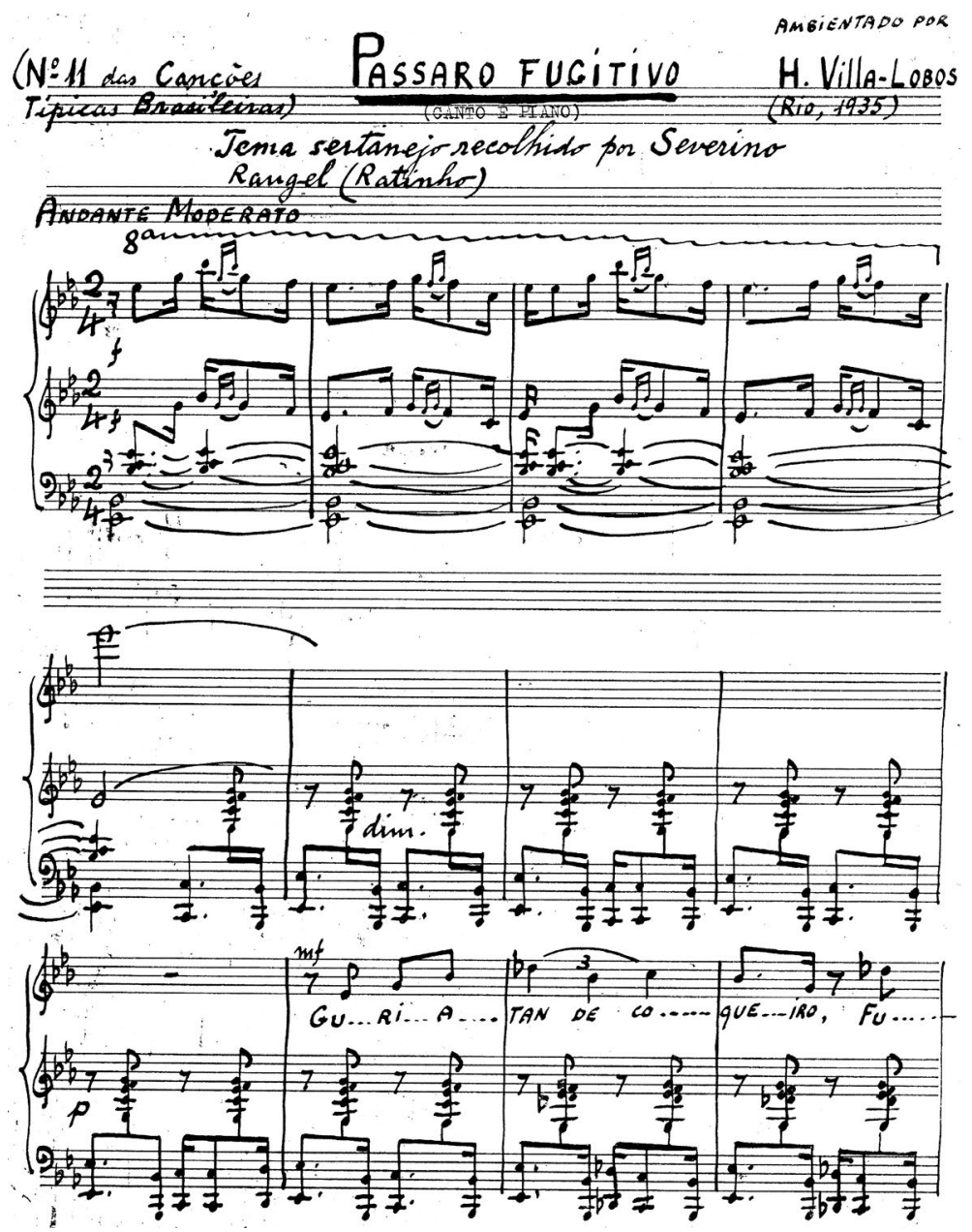

Villa-Lobos. Pássaro fugitivo.

Manuscrito, Museu Villa-Lobos, p.1. 

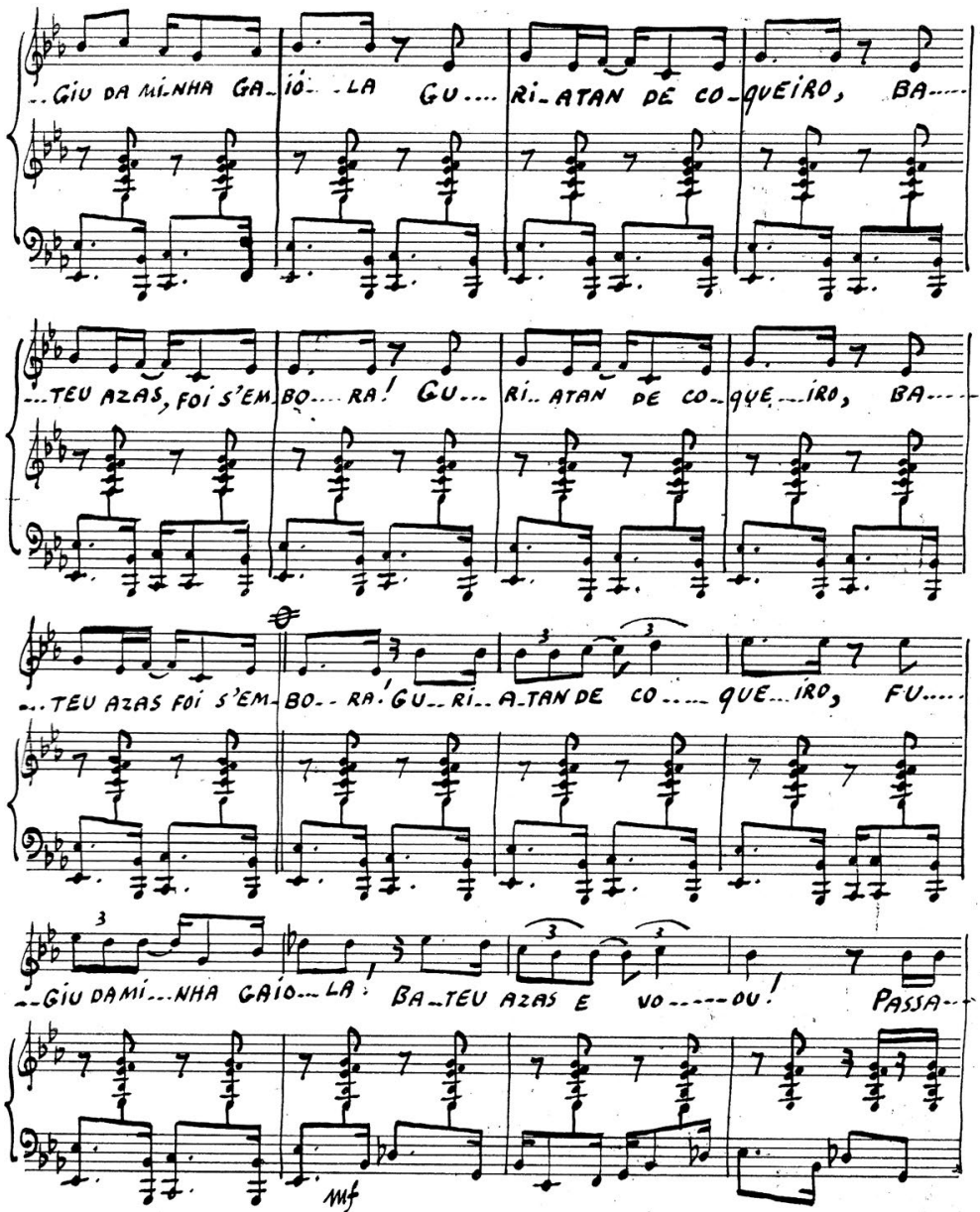

Villa-Lobos. Pássaro fugitivo.

Manuscrito, Museu Villa-Lobos, p.2. 

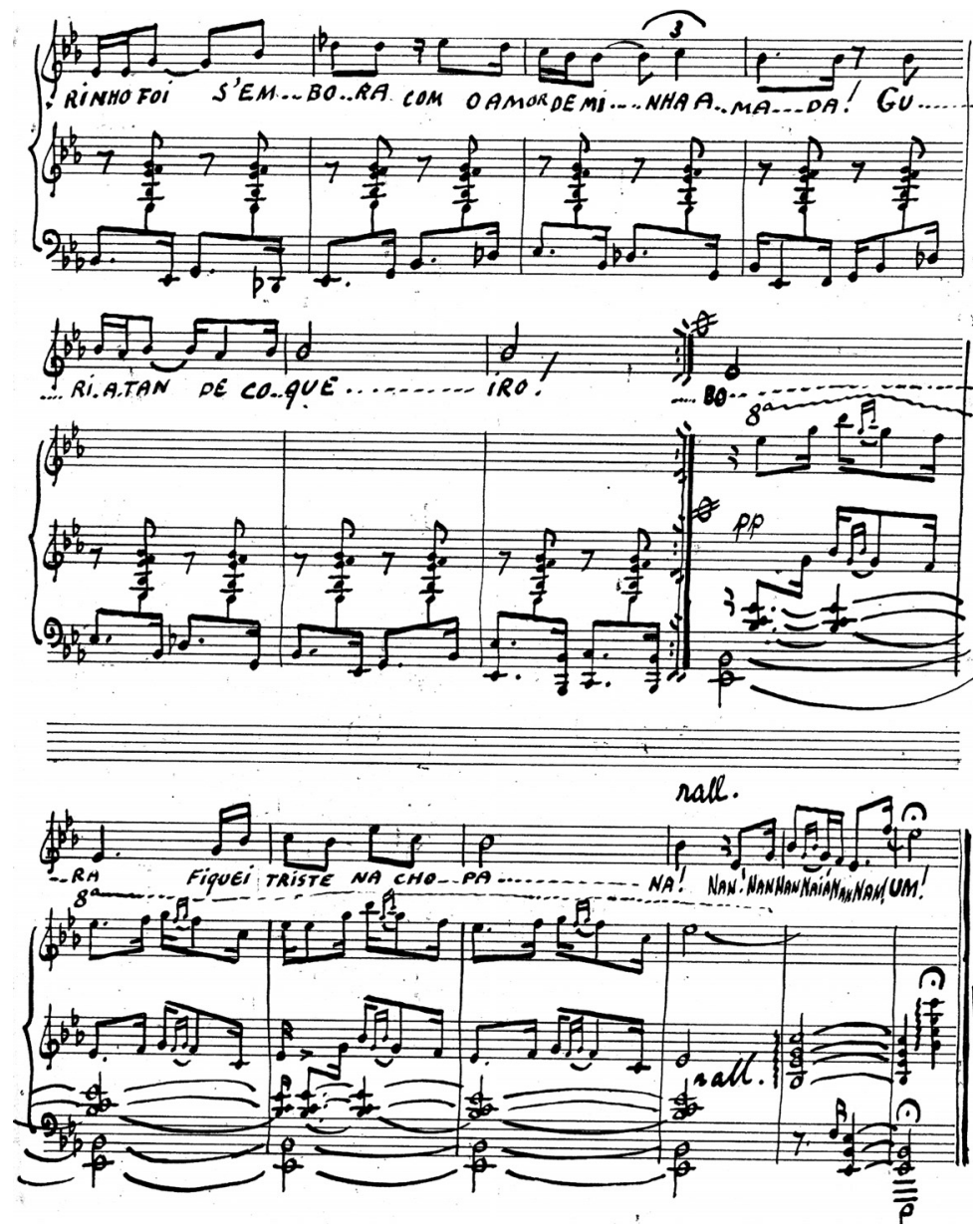

Villa-Lobos. Pássaro fugitivo.

Manuscrito, Museu Villa-Lobos, p.3. 


\section{Texto}

Guriatan de Coqueiro,

Fugiu da minha gaiola

Guriatan de Coqueiro,

Bateu azas, foi s'embora! asas

Guriatan de Coqueiro, Bateu azas foi s'embora! asas

Guriatan de Coqueiro,

Fugiu da minha gaiola!

Bateu azas e voou!

asas

Passarinho foi s'embora com o amor de minha amada!

Guriatan de Coqueiro!

Fiquei triste na chopana!

choupana

\section{Estrutura formal e harmônica}

Como muitas das canções sertanejas, esta canção está harmonicamente construída sobre modo mixolídio. O modo mixolídio foi introduzido no nordeste do Brasil pelas missões jesuíticas europeias que ocorreram durante os séculos XVI e XVII, fundindo-se completamente à musica folclórica e afro-brasileira: mi b - fá - sol - lá b-si $\mathrm{b}$ - dó - ré b-mi b.

Forma canção de seção única com introdução.

Introdução do piano: compassos 1 a 9, sendo que do compasso 1 ao compasso 4 o piano introduz a melodia principal e do compasso 5 ao compasso 9 introduz o ritmo para a melodia do cantor.

A primeira estrofe tem uma melodia mais grave e a segunda estrofe está baseada em um registro de altura mais elevada. $\mathrm{O}$ piano mantém o ostinato rítmico inicial do samba-canção. Há um registro dessa canção com Villa-Lobos ao piano. $\mathrm{O}$ autor executa os baixos dos compassos 7, 17 e 24 iguais aos do compasso 9. 


\section{Itabaiana (1935)}

Manuscrito não editado.

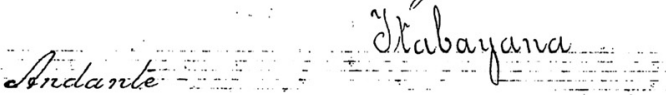

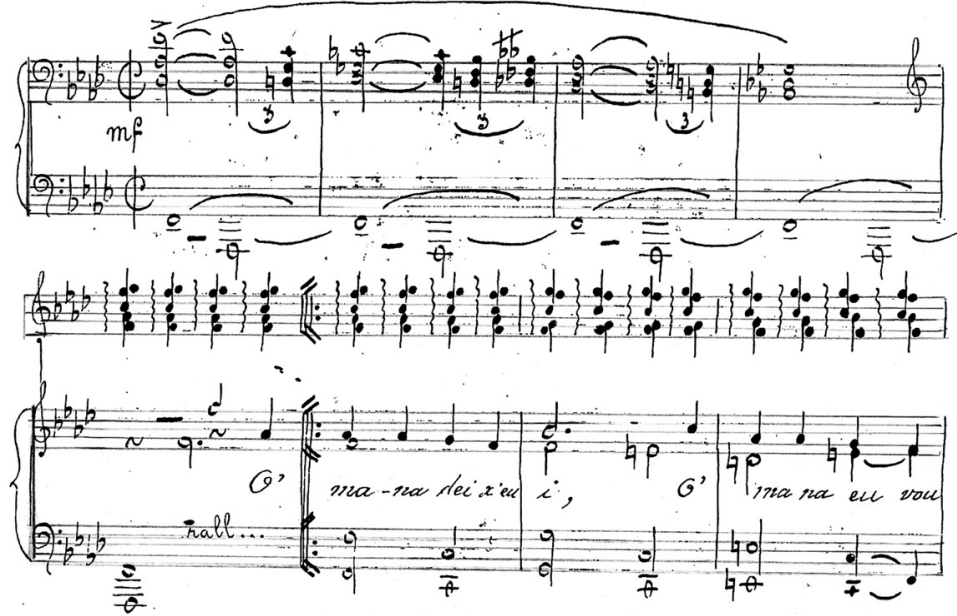

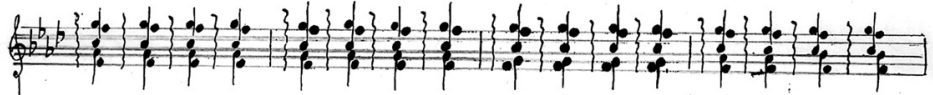
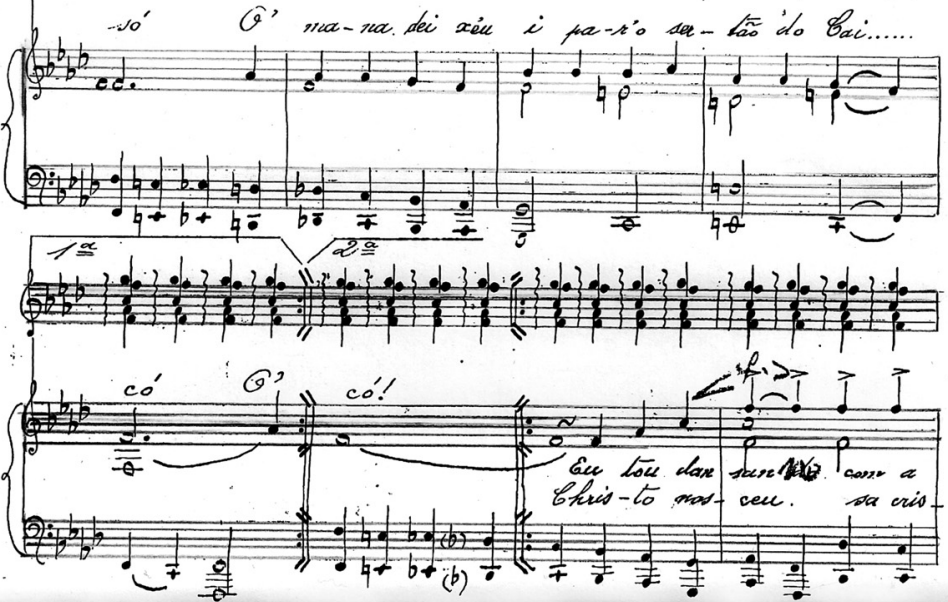

Villa-Lobos. Itabaiana.

Manuscrito, Museu Villa-Lobos, p.1. 
14:
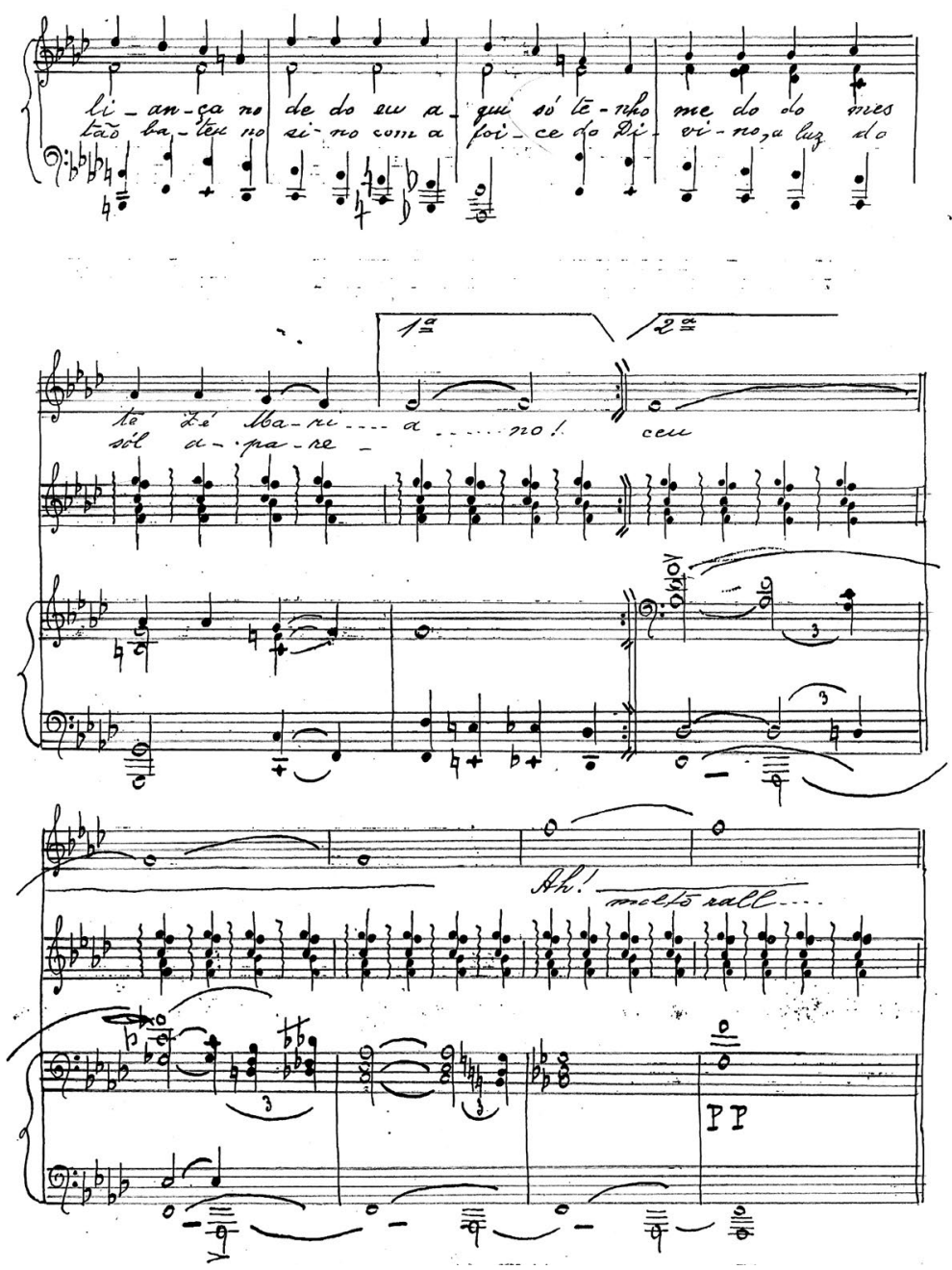

Villa-Lobos. Itabaiana.

Manuscrito, Museu Villa-Lobos, p.2. 


\section{Texto}

A canção está baseada em um tema sertanejo de origem indígena do estado da Paraíba do Norte. Não interferimos nas contrações e nas supressões de consoantes ou vogais como deix'eu, par'o, i em lugar de ir.
Ó mana deix'eu i,
Ó mana eu vou só
Ó mana deix'eu i
Par'o sertão do Caicó!
Ó mana deix'eu i,
Ó mana eu vou só
Ó mana deix'eu i
Par'o sertão do Caicó!

Eu tou dansando com aliança no dedo dançando eu aqui só tenho medo do mestre Zé Mariano!

Christo nasceu.

Cristo

Sacristão bateu no sino com a foice do Divino, a luz do sol apareceu.

Ah!

\section{Estrutura formal e harmônica}

Tonalidade: fá menor.

A canção é um arranjo para piano, voz e harpa da ária (cantiga) da Bachianas Brasileiras no4, para piano solo. Na canção Itabaiana, o compositor omite a seção B, vivace, da Bachianas, que é construída com o mesmo material temático da primeira parte.

A canção é constituída de introdução instrumental e duas seções, com duas estrofes: a primeira com o mesmo texto e a segunda com texto diferente. 
No. 3 from

\section{ARIA - (Cantiga)}

Bachianas Brasileiras No. 4

H. VILLA-LOBOS

Rio, 1935

\section{Moderato 84 = d}

ㄱ. 4. $b^{b}$.
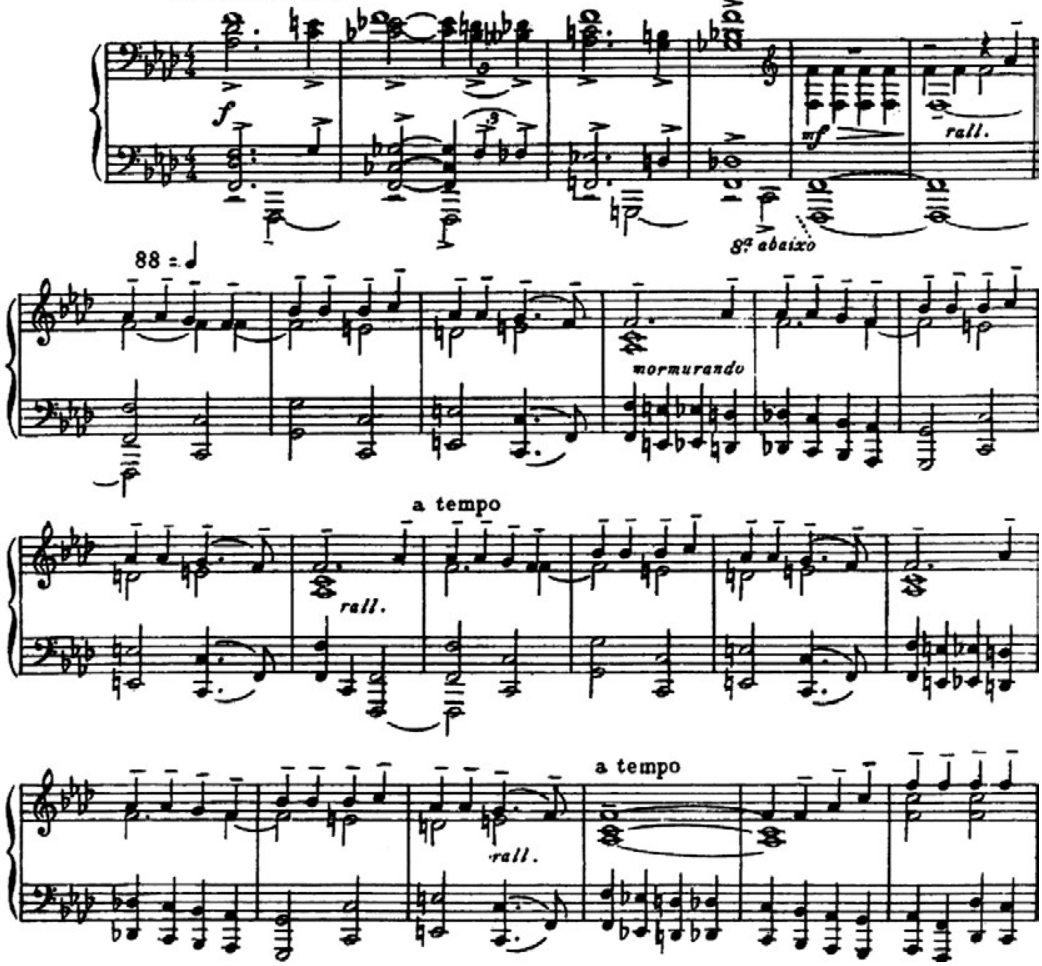

Villa-Lobos. Bachianas Brasileiras nº4, ária (cantiga), introdução.

CMP Consolidated Music Publishers, 1948. 

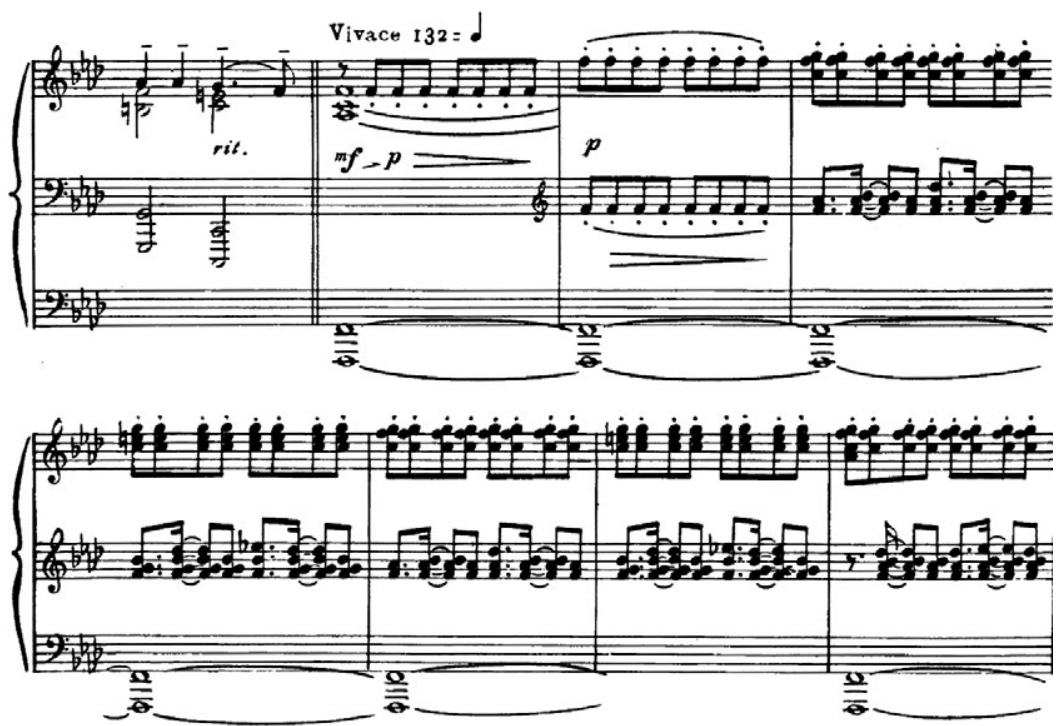

Villa-Lobos. Bachianas Brasileiras nº4, ária (cantiga), compassos 37-44 (seção B, vivace). CMP Consolidated Music Publishers, 1948. 


\section{Onde o nosso amor nasceu (1935)}

Manuscrito não editado.

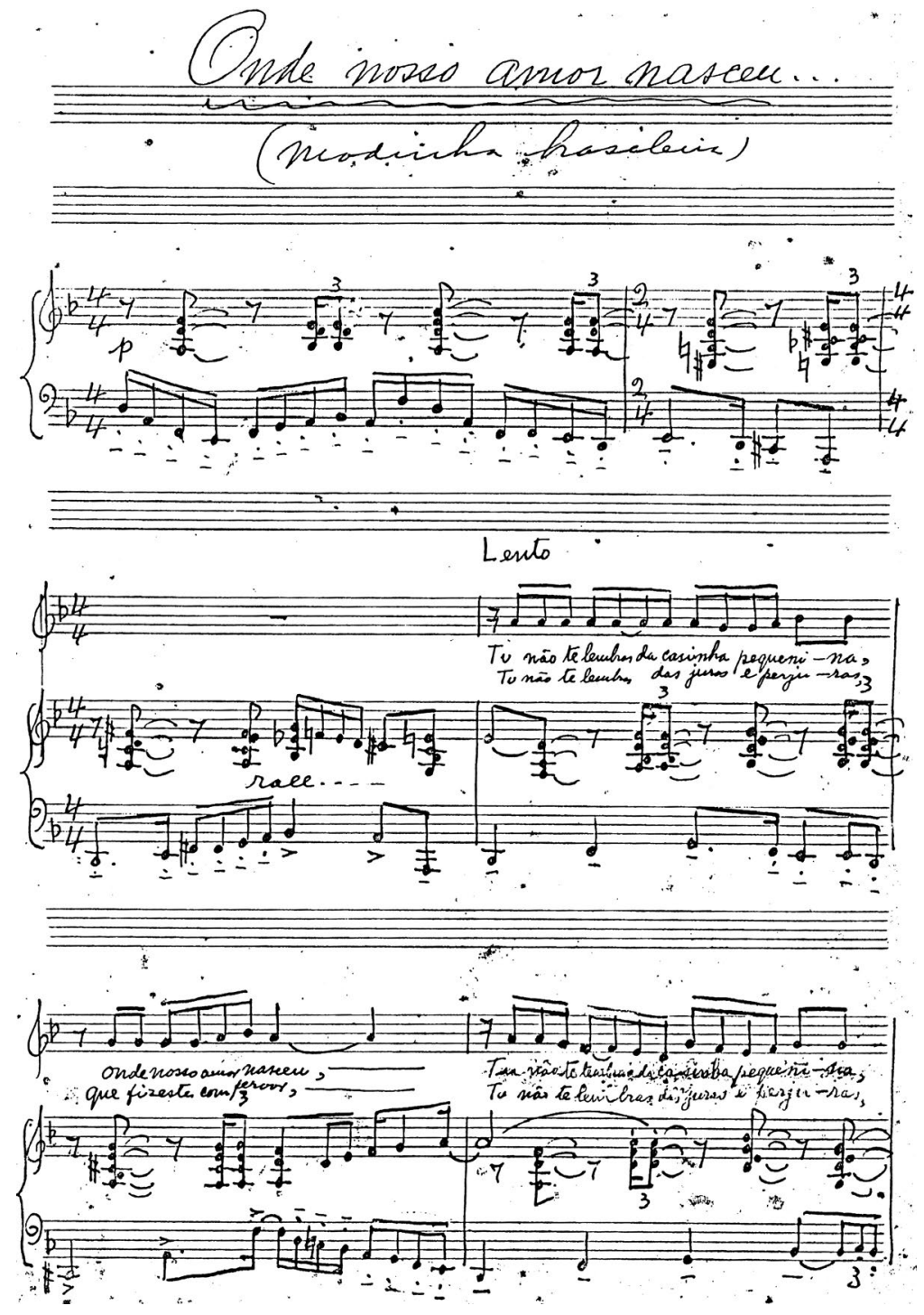

Villa-Lobos. Onde o nosso amor nasceu.

Manuscrito, Museu Villa-Lobos, p.1. 

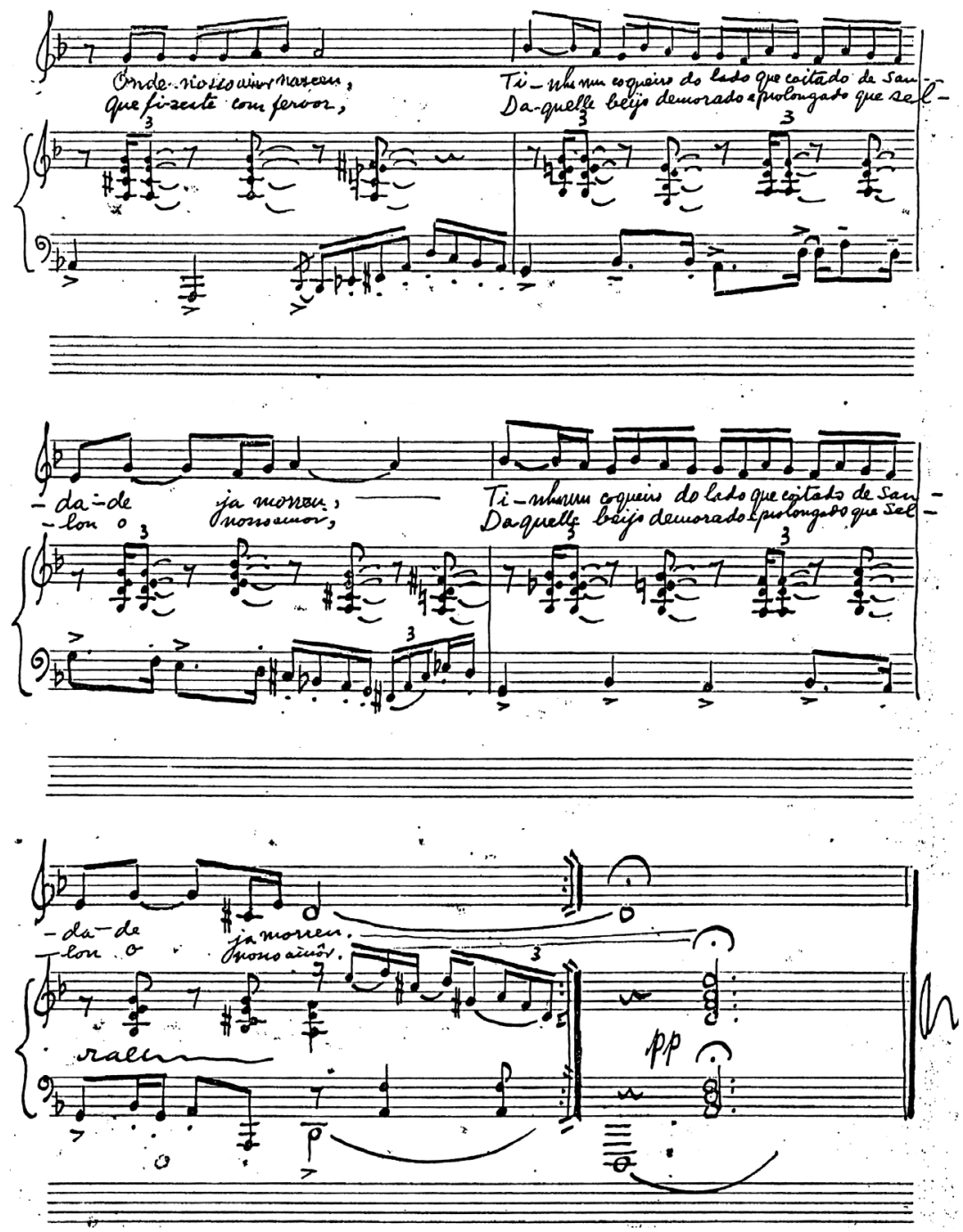

Villa-Lobos. Onde o nosso amor nasceu.

Manuscrito, Museu Villa-Lobos, p.2.

\section{Texto}

Tu não te lembras da casinha pequenina, onde o nosso amor nasceu, 
Tu não te lembras da casinha pequenina, onde o nosso amor nasceu,

Tinha um coqueiro do lado

que coitado de saudade já morreu,

Tinha um coqueiro do lado

que coitado de saudade já morreu.

Tu não te lembras das juras e perjuras,

que fizeste com fervor,

Tu não te lembras das juras e perjuras,

que fizeste com fervor,

Daquelle beijo demorado e prolongado

daquele

que selou o nosso amôr,

amor

Daquelle beijo demorado e prolongado

daquele

que selou o nosso amôr.

amor

\section{Estrutura formal e harmônica}

Tonalidade: ré menor.

Escritura típica do violão e da seresta, na qual a mão esquerda do pianista realiza o contraponto à melodia. A mão direita o acompanha com acordes de tônica, subdominante e dominante, reforçados algumas vezes por suas dominantes auxiliares.

\section{Aspectos interpretativos}

A seguir sugerimos alguns dedilhados úteis para o pianista.

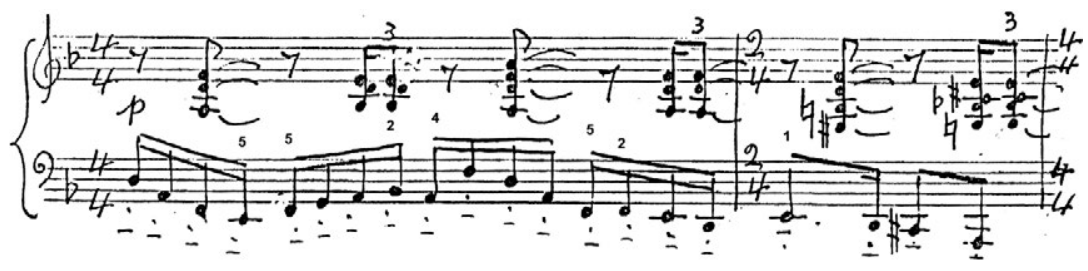

Villa-Lobos. Onde o nosso amor nasceu. Dedilhados dos compassos 1 e 2.

Manuscrito, Museu Villa-Lobos. 


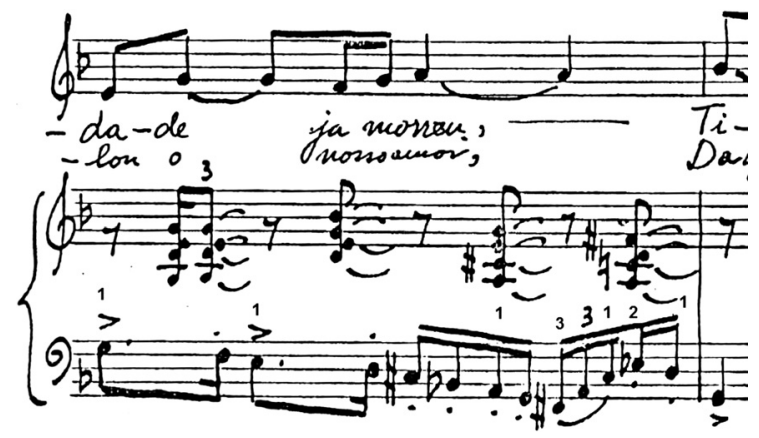

Villa-Lobos. Onde o nosso amor nasceu. Dedilhados do compasso 9. Manuscrito, Museu Villa-Lobos.

\section{Três Poemas Indígenas}

Tabela 4. Três Poemas Indígenas, data da composição/publicação, gênero e texto

\begin{tabular}{l|l|l|l}
\hline $\begin{array}{l}\text { Canidê Iounê- } \\
\text { Sabath }\end{array}$ & $\begin{array}{l}\text { 1926, 1929 } \\
\text { Éditions Max } \\
\text { Eschig }\end{array}$ & canção & $\begin{array}{l}\text { canção/letra } \\
\text { indígena } \\
\text { recolhida por Jean } \\
\text { de Léry (1553) }\end{array}$ \\
\hline Teiru & $\begin{array}{l}1926,1929 \\
\text { Éditions Max } \\
\text { Eschig }\end{array}$ & canção & $\begin{array}{l}\text { letra indígena } \\
\text { recolhida por } \\
\text { Roquette Pinto } \\
(1912)\end{array}$ \\
\hline Iara & $\begin{array}{l}1926,1929 \\
\text { Éditions Max } \\
\text { Eschig }\end{array}$ & $\begin{array}{l}\text { canção em forma } \\
\text { de passacaglia }\end{array}$ & $\begin{array}{l}\text { Mário de } \\
\text { Andrade }\end{array}$ \\
\hline
\end{tabular}

Os Três Poemas Indígenas foram compostos no Rio de Janeiro em 1926, e foram dedicados a Roquette Pinto.

Canidê Iounê-Sabath e Teiru, dos Três Poemas Indígenas, constavam do primeiro pacote assinado entre Villa-Lobos e a editora Max Eschig. Segundo Peppercorn (1994, p.19-20), o contrato assinado com a editora em abril de 1927 compreende as seguintes obras: segundo e terceiro trios com piano, terceiro quarteto de cordas, segunda sonata para violoncelo, Choros n2, 7 e 10; trio para oboé, clarinete e fagote; Teiru, Canidê Iounê-Sabath, dos Três Poemas Indígenas, e Na 
Bahia tem para coro a cappella. De acordo com informação adicional do diretor artístico da Max Eschig, Gerald Hugon, a Peppercorn, foram publicados também neste primeiro pacote o primeiro concerto para violoncelo e o noneto.

Segundo Wright (1992, p.48), "os Três Poemas Indígenas representam o pico do envolvimento indigenista de Villa-Lobos".

De acordo com o Museu Villa-Lobos, a primeira execução da obra aconteceu em 12.4.1929 no Teatro São Pedro, em Porto Alegre. Canidê Iounê-Sabath. Andino Abreu, canto; Elysena d'Ambrosio, pf.

De acordo com Appleby (1988, p.58), a primeira audição europeia com orquestra aconteceu em Paris, Maison Gaveau, com a Orquestra de Concertos de Colônia e L'Art Choral, Vera Janacopolus, voz, e Villa-Lobos, regente, em 5.12.1927.

\section{Canidê Iounê-Sabath}

(Ave amarela - canção elegíaca)

(Rio de Janeiro, 1926)

\section{Texto}

Tema indígena brasileiro, recolhido por Jean de Léry, em 1553.

Canide ioune Canide ioune heura uoêch!

Canide ioune Canide ioune heura uoêch

Hé heura heura heura;

heura heura heura heura uoêch!

Hé heura heura heura

heura heura heura heura uoêch!

Canide ioune, Canide ioune heura uoêch!

Canide ioune Canide ioune heura uoêch!

Os sinais de "vírgula" e "ponto e vírgula" e "exclamação" aparecem ao acaso, sem critérios de fraseado. Sugerimos aplicar os referidos sinais de acordo com o fraseado vocal da melodia, ou seja: 
Canide ioune, Canide ioune, heura uoêch! Canide ioune, Canide ioune, heura uoêch! Hé heura heura heura; heura heura heura heura, uoêch! Hé heura heura heura; heura heura heura heura, uoêch! Canide ioune, Canide ioune, heura uoêch! Canide ioune, Canide ioune, heura uoêch!

\section{Estrutura formal e harmônica}

Melodia: segundo Tarasti (1995, p.226), “a canção Canidê IounêSabath é baseada em uma conhecida canção indígena, coletada por Jean de Léry em 1585. A melodia aparece ligeiramente transformada no Dictionnaire de la musique, de Jean-Jacques Rousseau, de 1786, e aparece identificada como uma canção dos índios do Canadá. Ainda segundo o mesmo autor (idem, ibidem), Villa-Lobos provavelmente utilizou nos Três Poemas Indígenas a versão transcrita pelo compositor brasileiro Luciano Gallet (1893-1931).

A melodia é construída sobre uma escala hexatônica, evocando um sistema musical arquetípico das civilizações indígenas pré-tonais.

Seção A - Movimento de marcha lenta: compassos 1 a 21. Polarização sobre a nota mi. Corresponde à primeira seção do texto indígena.

Seção B - Peu animé: compassos 22 a 33. Polarização sobre nota ré. Corresponde à segunda seção do texto indígena.

Atenção para a tradução do andamento do francês: o correto é "pouco animado" e não "pouco animando", que significa animando pouco a pouco. Na versão para coro misto duplo a seis vozes - publicada pela Editora Irmãos Vitale, Canto Orfeônico, 2ํVolume (1950) - encontra-se a indicação poco più mosso.

Seção A (reprise) - Tempo I: compassos 34 a 53. Polarização sobre nota mi. Corresponde à terceira seção do texto indígena. 

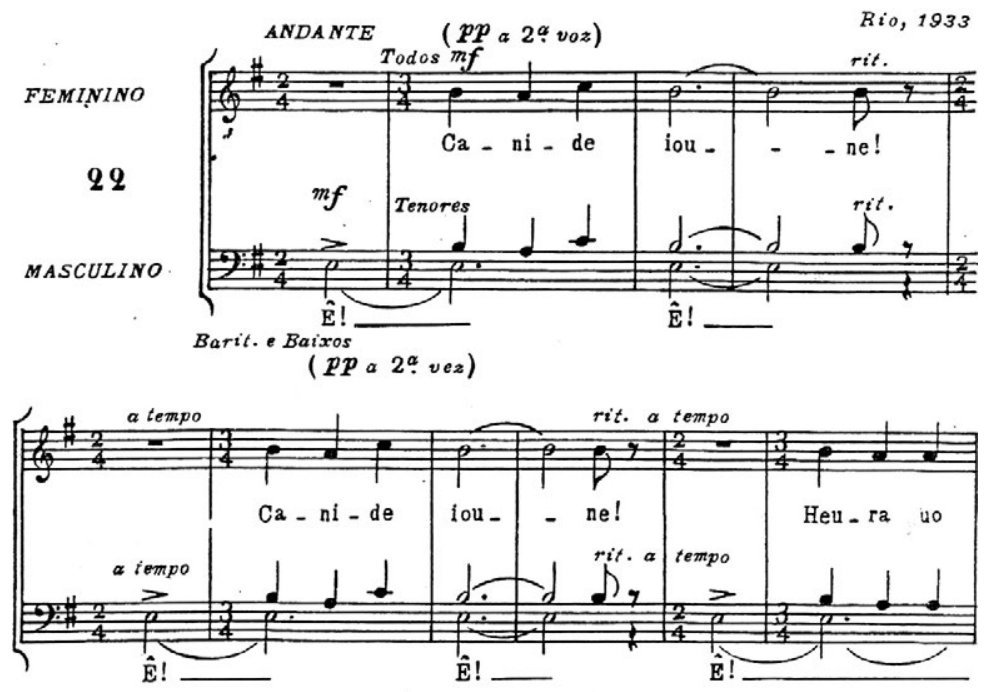

POCO PIÙ MOSSO

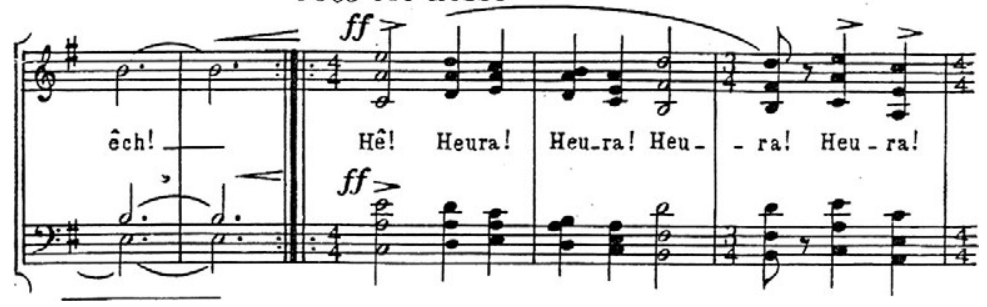

Villa-Lobos. Canidê Iounê-Sabath, Canto Orfeônico, 2ํvolume, versão para coro a 6 vozes.

Edição Irmãos Vitale, São Paulo, Brasil.

Estatisticamente, a nota que mais aparece na melodia vocal é a nota mi, quarenta vezes, seguida da nota ré, que aparece 24 vezes. Depois disso aparecem as notas fá, 12 vezes, sempre como vizinha superior do tom principal (ou seja, atua como sensível de superior da nota mi); a nota sol, seis vezes; a nota lá, quatro vezes; a nota dó, por último, que aparece somente como sensível inferior da nota ré, quatro vezes. A nota si não aparece na melodia vocal.

Ritmo: Villa-Lobos alterna o uso de fórmulas de compassos 3/4 e 4/4, criando assim uma irregularidade da métrica musical, evitando quadraturas de oito compassos e ritmos tradicionais. Por meio desse 
procedimento, o compositor tem a intenção de caracterizar o sistema musical das civilizações pré-tonais.

Introdução piano: compassos 1 a 3. Fórmula de compasso: 3/4.

Seção A: compassos 4 a 21. Fórmula de compasso 4/4 + 3/4 +3/4.

Seção B: compassos 22 a 33. Fórmula de compasso quatro vezes 4/4 + 3/4; quatro vezes $4 / 4+3 / 4$.

Reprise de A: compassos 34 a 50.

Reprise da introdução/coda pianística: compassos 51 a 53 com fórmula de compasso em 3/4.

\section{Edição e manuscrito}

Não há manuscrito disponível da canção para consulta. Aparentemente, a edição não tem erros na parte musical. Muitas estruturas (Gestalten) são repetidas ao longo da obra, o que permite comparar bem o material musical utilizado para a voz e para o piano. $\mathrm{O}$ arranjo para coro misto a seis vozes publicado pela Editora Irmãos Vitale, citado anteriormente, também permite o trabalho de comparação musicológica.

\section{Teiru}

(Rio de Janeiro, 1926)

"D'après une chanson qui célèbre la mort d'un cacique de la tribu des indiens Paricis, de la province de Matto Grosso, au Brésil, recueillie par Roquette Pinto en 1912”: Baseada em uma canção que celebra a morte de um cacique da tribo dos índios parecis, da província de Mato Grosso, Brasil, recolhida por Roquette Pinto em 1912.

\section{Texto}

Uiaê autiá harênêzê

Zalôkarê uêrorêtô...

Amôkutiá tanohâná...

Niiitatiàhazakô...

Tahârêkalôrê maucê

Tahârêkalôrê maucê 
Uai uazarê uaitekô

\section{Uaiuazarê uaitekô}

Uaié autiá hârênêzê...

Zalôkârê uêrôrêtô...

\section{Uaiuazarê uaitekô}

Han!

A palavra Uaiuazarêé provavelmente uma palavra só. Aqui temos um provável erro de edição no texto. É importante para o intérprete definir as palavras, pois delas depende a escolha do fraseado e da respiração correta.

\section{Estrutura formal e harmônica}

Segundo Tarasti (1995, p.226), "Teiru faz parte da coleção de Roquette Pinto, Rondônia. A parte de piano é uma espécie de Funerailles". Segundo Peppercorn (1995, p.25), "Teiru demonstra o talento excepcional de Villa-Lobos para transmitir o caráter de uma melodia, sustentando-a com poucos acordes".

Seção A1 - piano solo. Moderé: compassos 1 a 9 . Sobre um ostinato, Villa-Lobos antecipa a melodia que será apresentada pelo canto.

Seção B1 - voz e piano. Très lent: compassos 10 a 22. A melodia da canção inteira é construída sobre quatro notas somente - si, ré, mi, fá\#. Novamente, o compositor evoca um sistema musical arquetípico das civilizações pré-tonais e não europeias. $O$ piano nessa seção desenvolve uma harmonia tipicamente tonal, um coral organístico que acompanha a melodia de inspiração indígena.

Seção A2 - Voz e piano. Tempo I: compassos 23 a 34. Variação da seção A1, apresentada pelo piano. Apresenta os insistentes motivos da voz acompanhados pelo ostinato apresentado na seção A.

Seção B2 - voz e piano. Très lent comme auparavant: compassos 35 a 45. Variação da seção B1. O compositor acrescenta um bordão ao coral organístico: a nota si. Um melisma do cantor, nos compassos 43 a 45, conclui a canção.

Tarasti (1995, p.226) chama a atenção para o provável emprego da microtonalidade na melodia dos compassos finais da canção. 
Peppercorn (1991, p.25 e 31) chama a atenção para o fato de que a mesma configuração melismática de Teiru aparece com pequenas alterações em uma canção do início da carreira de Villa-Lobos, Louco (1917), sendo também utilizado no andante quasi adagio do Quartour(1921).

\section{Aspectos interpretativos}

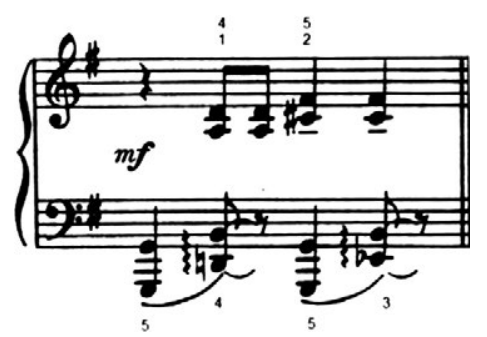

Villa-Lobos. Teiru, dedilhado compasso 4. Éditions Max Eschig, Paris, 1929.

Quando Villa-Lobos escreve uma grande ligadura no baixo, significa que o pianista deverá sustentar o pedal direito. Esse procedimento de grafia é característico da música francesa de Claude Debussy e Maurice Ravel.

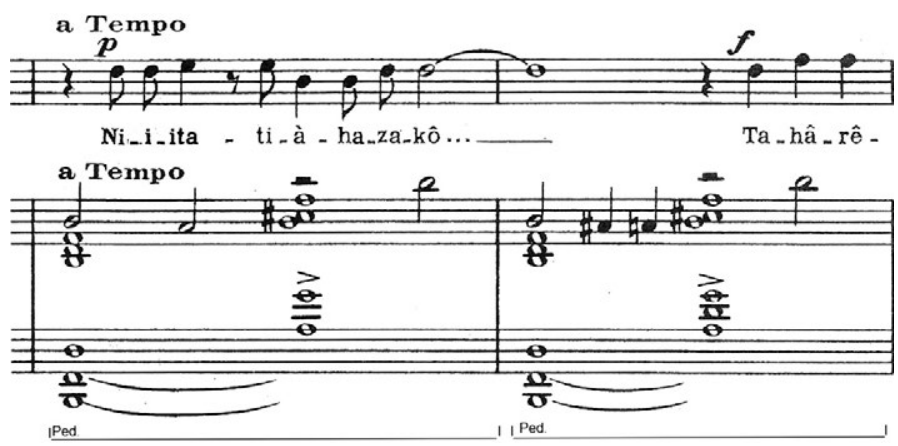

Villa-Lobos. Teiru, pedal compassos 17-8. Éditions Max Eschig, Paris, 1929. 


\section{Edição e manuscrito}

1. Incoerência das palavras no texto indígena.

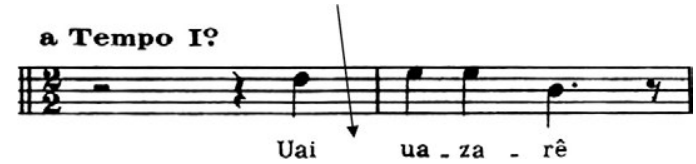

Villa-Lobos. Teiru, compassos 23-4.

Éditions Max Eschig, Paris, 1929.

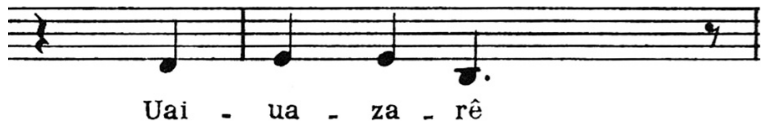

Villa-Lobos. Teiru, compassos 23-4 e 30-1.

Éditions Max Eschig, Paris, 1929.

2. Não há manuscrito da canção disponível para consulta. Na seção A1, há um provável erro de edição. A nota marcada não se enquadra na regularidade do ostinato composto por Villa-Lobos. A nota é provavelmente si e não lá, como impressa na edição.
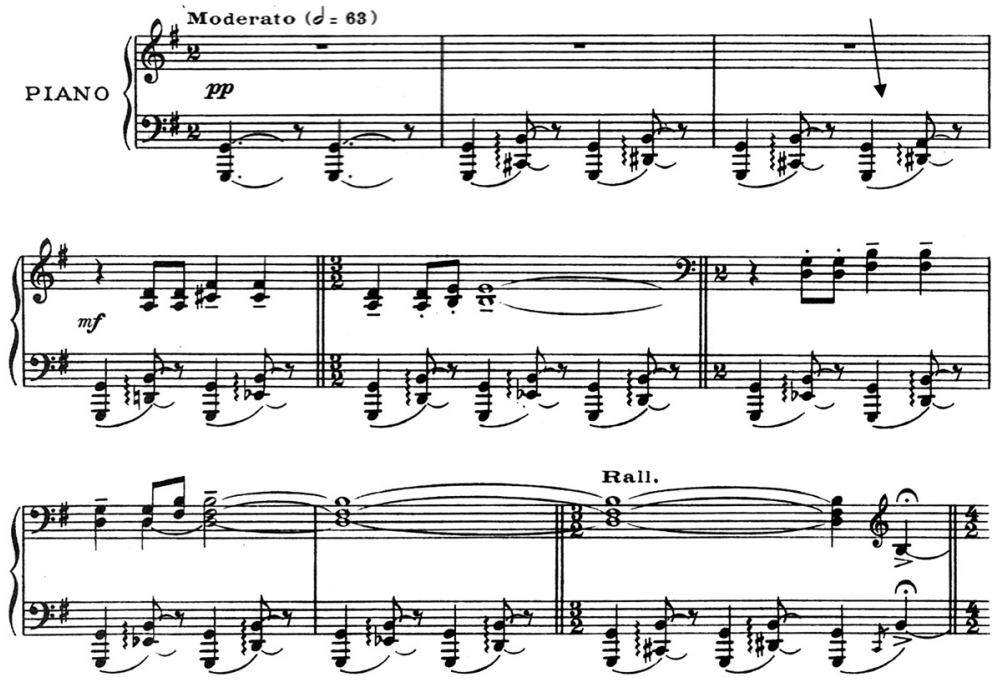

Villa-Lobos. Teiru, seção A, compassos 1-9.

Éditions Max Eschig, Paris, 1929. 


\section{Iara}

(Rio de Janeiro, 1926)

\section{Poesia}

Mário de Andrade

Neste rio tem uma iára... iara

De primeiro o velhoque tinha visto a iára iara Ah á! Ah á! Ah!

Contava que ela era feiosa, muito!

Prêta gorda manquitóla ver peixe boi preta, manquitola Felizmente o vélho já morreu faz tempo! velho $\mathrm{Ah}$ ! Ah! Ah!

Duma feita madrugada de neblina,

Um moço que sofria de paixão

Por causa duma india que não queria ceder pra ele índia Se levantou e desapareceu na agua do rio. água Se levantou e desapareceu na agua do rio Ah! Ah! Ah!

Então principiaram a falar que a iára cantava, éra moça, era Cabelos de limo esverdeados do rio.

Ah! Ah! Ah!

Ah! Ontem o piá brinca brincando

Subiu na igára do pai abiscada no porto

Botou a mãosinha na água funda igara

E vai, a pirânha abocanhou a mãosinha do piá

piranha, mãozinha

Neste rio tem uma iára...

Neste rio tem uma iára...

Iara ou Uiara (do tupi 'y-îara, senhora das águas ou mãe-d'água), segundo o folclore brasileiro, é uma sereia. De pele morena clara e cabelos negros, tem olhos verdes e costuma banhar-se nos rios, cantando uma melodia irresistível. Os homens que a veem não 
conseguem resistir a seus desejos e pulam nas águas. A Iara os leva para o fundo do rio, de onde nunca mais voltam. Os que retornam ficam loucos e apenas uma benzedeira ou algum ritual realizado por um pajé consegue curá-los. Os índios têm tanto medo da Iara que procuram evitar os lagos ao entardecer. ${ }^{7}$

\section{Estrutura formal e harmônica}

Iara é uma canção na qual a voz conta uma história fantástica, desenvolvida sobre uma passacaglia instrumental, uma aria variata. Entre os Três Poemas Indígenas, Iara é o maior de todos e é a canção mais elaborada musicalmente. De acordo com Tarasti (1995, p.228), em Iara não há menção à utilização de temas indígenas, mas podemos encontrar semelhanças entre o tema de abertura do piano com o fonograma 14.605 de Roquette Pinto. Tarasti chama a atenção para a forte intensificação musical em direção ao seu final.

Peppercorn (1991, p.31) remarca que a música vocal de VillaLobos mudou rapidamente em poucos anos:

a força dramática desta canção [Iara], devido em parte a sua concisão e meios de expressão extremamente precisos, é uma antecipação estilística de obras importantes que vieram posteriormente. No entanto, Villa-Lobos raramente usou tamanha força dramática com o mesmo sucesso e economia nas composições mais extensas, incluindo, em particular, seu trabalho sinfônico.

Tema: Modéré nos compassos 1 e 2. Recitativo inicial. Acorde de si b menor.

Un peu animé (semínima =112): compassos 2 a 16 .

Um bordão sobre a nota si bemol polariza harmonicamente o tom de si b menor em toda a seção A.

A métrica nos compassos iniciais é propositadamente irregular para não caracterizar uma quadratura clássica europeia.

Compassos 3 a 7: fórmulas de compassos 3/4 e 4/4.

Compasso 8: fórmula de compasso $4 / 4$.

Compasso 9: fórmula de compasso 5/4.

7 Disponível em: <http://pt.wikipedia.org/wiki/Iara>. 
Compassos 10 a 15: fórmula de compasso 4/4. Os acentos irregulares emprestam uma característica fragmentada à seção.

Os compassos 13, 14 e 15 trazem um material temático importante que será utilizado no fechamento da seção B, no fechamento da seção Ce na coda final. Acompanha a voz na emissão da interjeição “Ah!”. Ver os acentos rinforzando ff nos compassos 13, 14 e 15, que mais uma vez emprestam uma irregularidade métrica ao discurso musical. Compasso $13=3 / 4+1 / 4$, compasso $14=3 / 4+1 / 4$, compassos 15 e $16=2 / 4+1 / 4+4 / 4$.

Variação 1: Le même mouvement: compassos 17 a 24. A parte do canto desloca seu centro em meio tom acima, polarizando a nota si natural. A parte do canto concorda harmonicamente com a mão direita do pianista. No entanto, a mão esquerda do pianista polariza a nota mi bemol - como podemos constatar no baixo da parte do piano -, fazendo uma referência harmônica ao IV grau de si bemol.

A parte pianística do acompanhamento aplica uma técnica politonal que é típica da escrita de Villa-Lobos, ou seja, usar a alternância da mão direita sobre as notas brancas com a mão esquerda sobre as notas pretas. Essa técnica produziu obras ilustres, como o Polichinelo, da Prole do Bebê, ou os ritmos alternados das mãos presentes na Festa no sertão, parte do Ciclo Brasileiro.

Nos compassos 25 a 28 temos a repetição do material temático stravinskiano apresentado nos compassos de 13 a 15, acompanhando a mesma interjeição "Ah!".

Variação 2: Un peu moins: compassos 29 a 56. Novo bordão explorando fá \# - sol na mão esquerda. O material musical da seção A é desenvolvido, e o número de compassos, expandido. Há grande diversidade de fórmulas de compasso para evitar qualquer referência à periodicidade clássica. Vejamos: no compasso 29 - 4/4, no compasso 30 - 4/8, no compasso $31-5 / 8$, no compasso $32-4 / 4$, no compasso $33-4 / 8$, no compasso $34-5 / 8$, nos compassos $35 / 36$ - 4/4, no compasso 37 - 5/8, no compasso 38 - 4/4. O quaternário estabiliza-se para introduzir musicalmente o recitativo do canto, no qual as melodias do canto e do piano têm maior relevância que o fator 
métrico. Assim, em 42 o bordão rítmico instrumental se interrompe, cedendo lugar a um recitativo vocal que é acompanhado de um contraponto instrumental melódico e expressivo.

Nos compassos 57 a 61, Comme avant, polariza novamente a nota mi bemol e os materiais temáticos stravinskianos dos compassos 13 a 15 aparecem variados, acompanhando a mesma interjeição "Ah!" da voz.

Variação 3: Animé (semínima = 120): compassos 64 a 92.

A cada variação, o compositor expande a amplitude dos intervalos do canto. Na exposição temática, a melodia tem caráter quase estático. Villa-Lobos desenvolve a linha melódica, e a cada nova variação expande seus intervalos da voz, tornando-os cada vez mais expressivos. Na variação 3 o compositor compõe uma linha melódica angulosa, cromática, explorando intervalos típicos da escola expressionista (como a sétima maior), até agora não utilizados nessa canção.

Na poética musical de Villa-Lobos, a sedução hipnótica da Iara aumenta progressivamente com o desenvolvimento das variações da passacaglia.

Grande seção solo instrumental dos compassos 74 a 85 .

Variação 4: Un peu moins: compassos 93 a 110.

Ostinato sobre a "tônica" si bemol. O compositor acrescenta ao ostinato o material contrapontístico que fora apresentado na variação 2. No entanto, a linha melódica da voz e o contraponto pianístico são mais dramáticos. A linha melódica da voz continua sempre expressiva, explorando intervalos largos e notas agudas de longa duração.

As variações 3 e 4 são o clímax da canção.

Coda: compassos 111 a 117.

Recitativo do canto (na edição Max Eschig, há um erro de digitação: à vontade/e não/à voutade). O ostinato dilui-se com golpes em staccato na região grave do piano, $f f$ a $p p$.

\section{Aspectos interpretativos}

O dedilhado sugerido abaixo poderá ser útil para a execução da seção compreendida entre os compassos 17 e 24. 


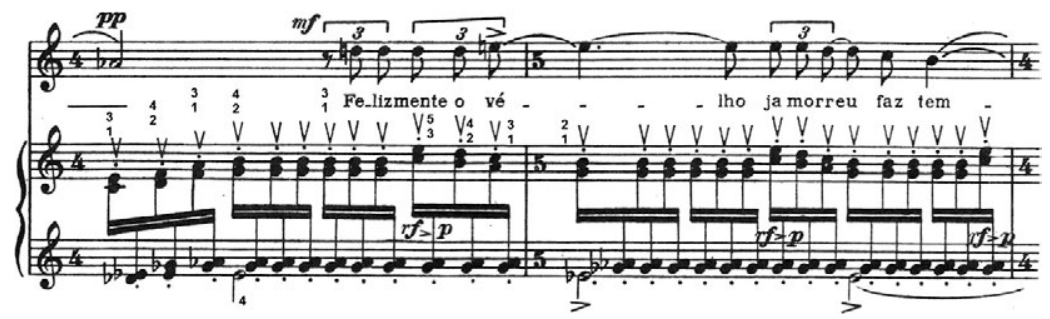

Villa-Lobos. Iara, compassos 21-2.

Éditions Max Eschig, Paris, 1929.

\section{Edição e manuscrito}

Há um interessante manuscrito incompleto dessa canção que se encontra disponível no Museu Villa-Lobos. Trata-se de uma versão bastante diferente da impressa pela Max Eschig, pois encontramos vários acréscimos de notas e inversões de motivos musicais.

As incongruências de edição ficam claras e podem ser observadas por esse manuscrito. Face às informações, o intérprete poderá decidir qual caminho seguir.

1. Várias notas acrescentadas no baixo da mão esquerda.

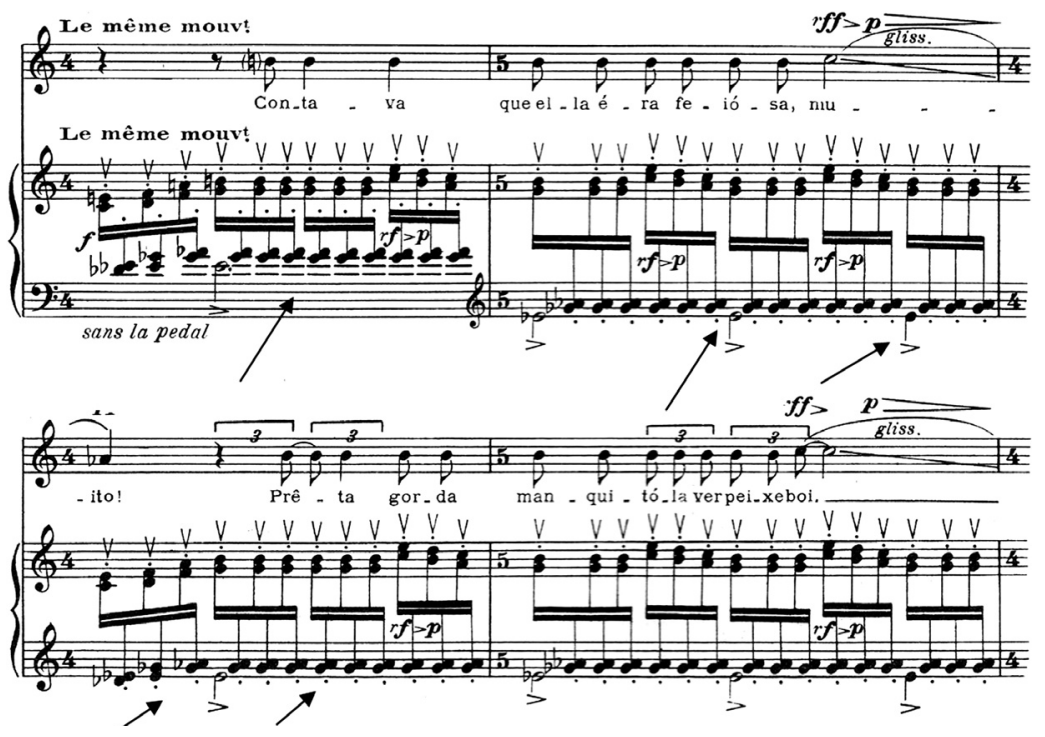

Villa-Lobos. Iara, compassos 17-20.

Éditions Max Eschig, Paris, 1929. 


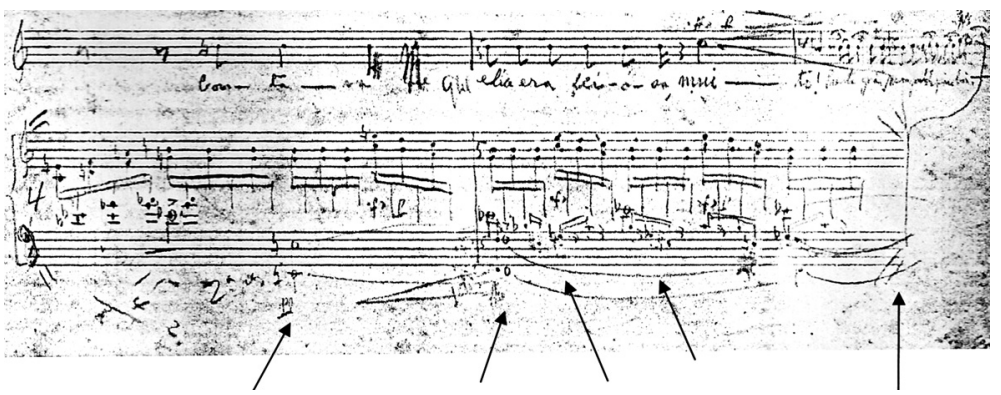

Villa-Lobos. Iara, compassos 17-20.

Manuscrito, Museu Villa-Lobos, Rio de Janeiro.

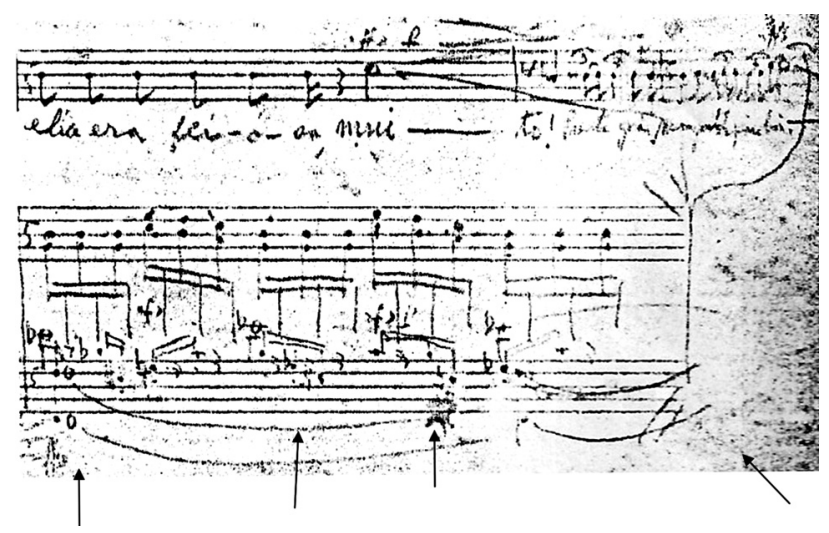

Villa-Lobos. Iara, compasso 18 e sinal de repetição.

Detalhe do manuscrito, Museu Villa-Lobos, Rio de Janeiro.

2. Baixos acrescentados na mão esquerda.

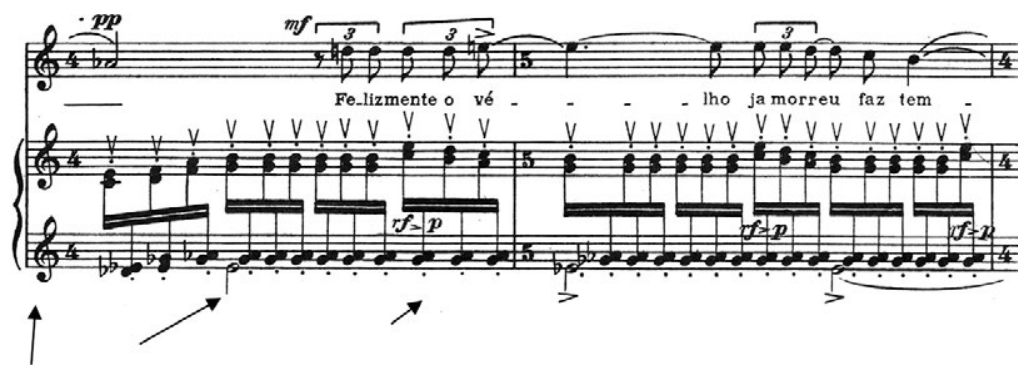

Villa-Lobos. Iara, compassos 21-2.

Éditions Max Eschig, Paris, 1929. 


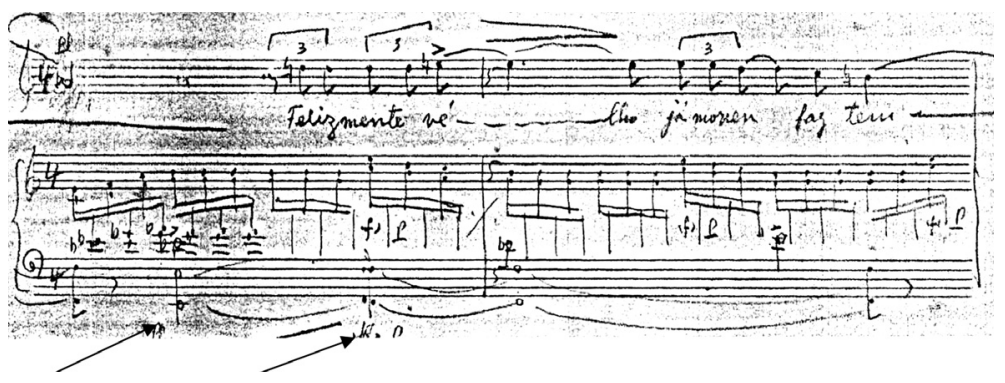

Villa-Lobos. Iara, compassos 21-2.

Manuscrito, Museu Villa-Lobos, Rio de Janeiro.

3. Erro de ritmo no baixo da mão esquerda.
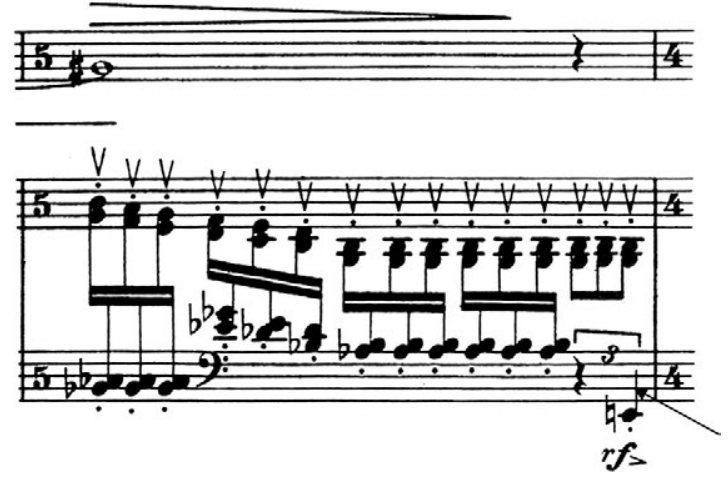

Villa-Lobos. Iara, compasso 24.

Éditions Max Eschig, Paris, 1929.

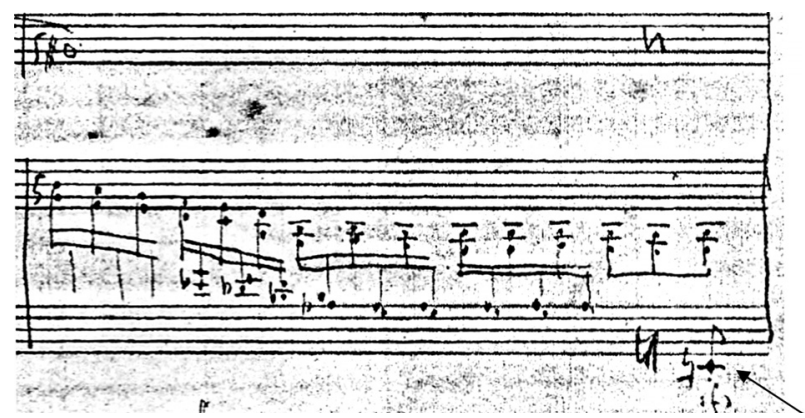

Villa-Lobos. Iara, compasso 24.

Manuscrito, Museu Villa-Lobos, Rio de Janeiro. 
4. Altura diferente anotada para a nota si bemol.

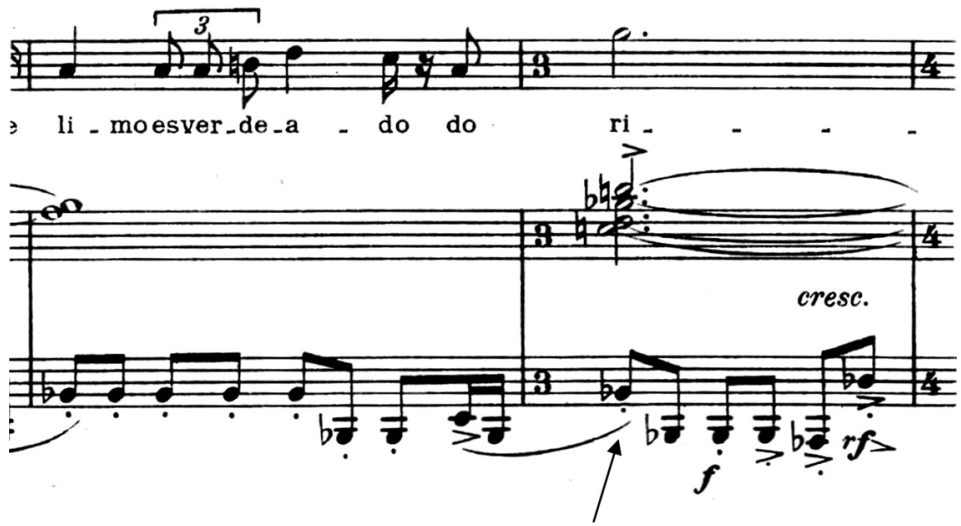

Villa-Lobos. Iara, compassos 71-2.

Éditions Max Eschig, Paris, 1929.

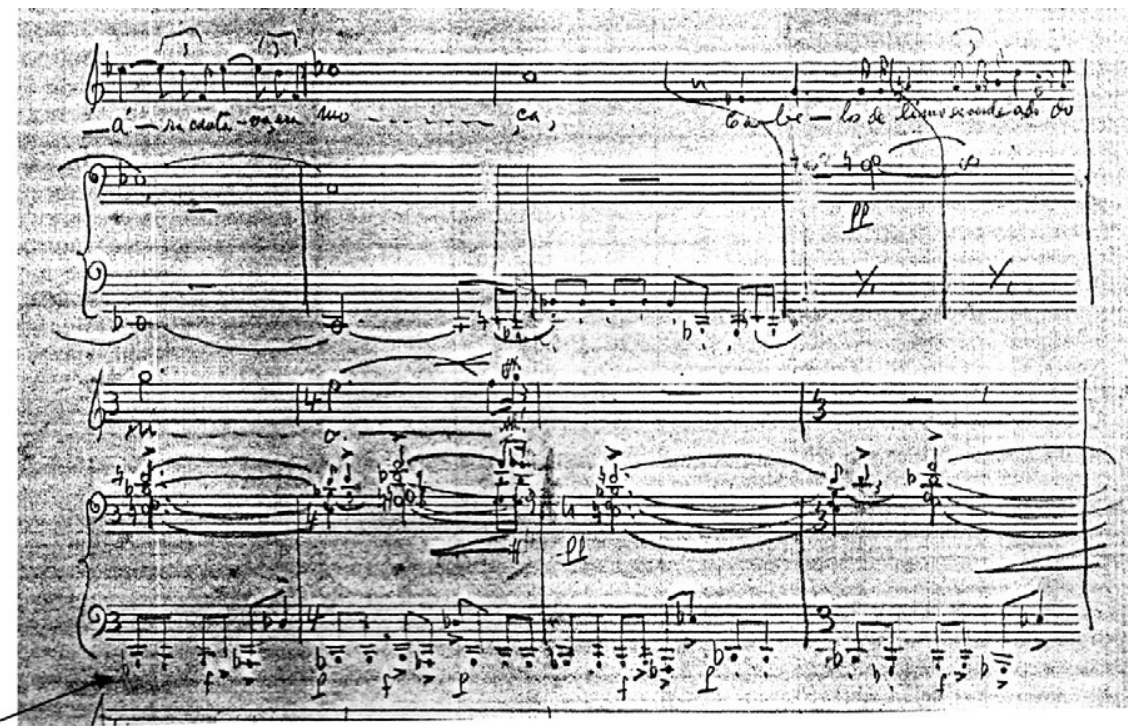

Villa-Lobos. Iara, compassos 67-75.

Manuscrito, Museu Villa-Lobos, Rio de Janeiro. 
5. Os motivos em semicolcheias têm uma configuração bem diferente da do manuscrito em questão.

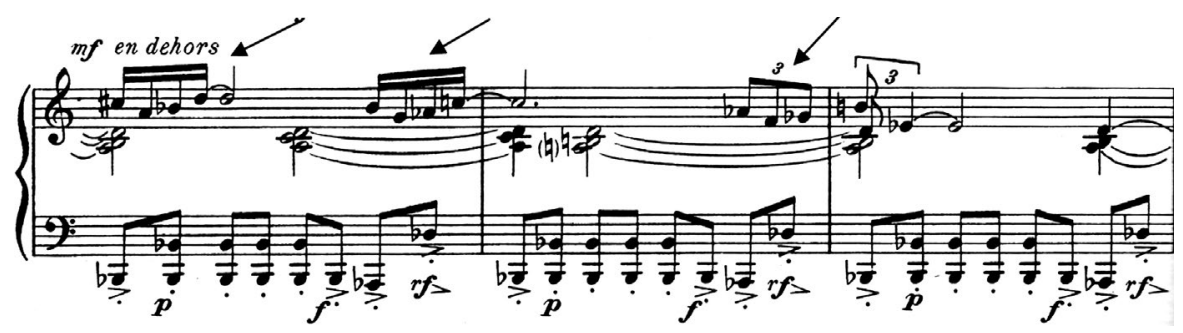

Villa-Lobos. Iara, compassos 82-4.

Éditions Max Eschig, Paris, 1929.

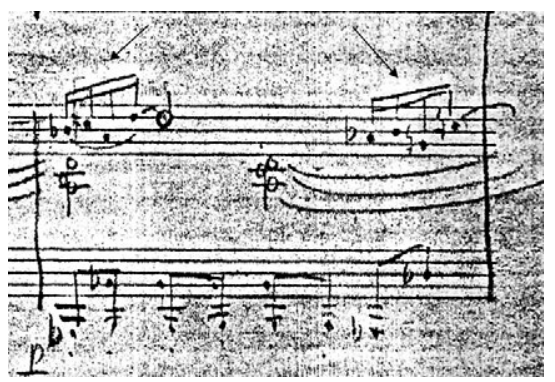

Villa-Lobos. Iara, compassos 80-2.

Manuscrito, Museu Villa-Lobos, Rio de Janeiro.

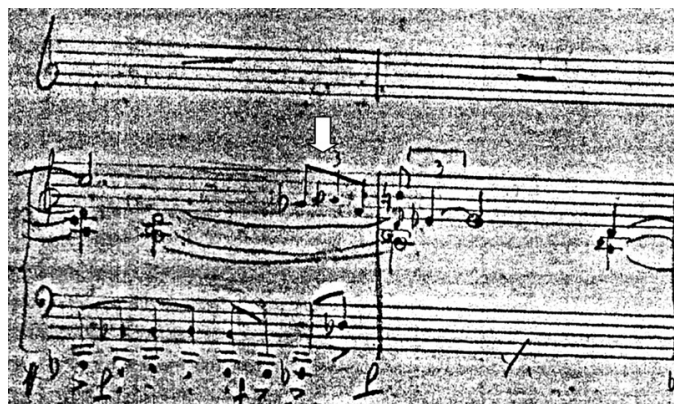

Villa-Lobos. Iara, compassos 83-4.

Manuscrito, Museu Villa-Lobos, Rio de Janeiro. 
6. Os motivos assinalados abaixo têm uma configuração diferente da do manuscrito em questão.

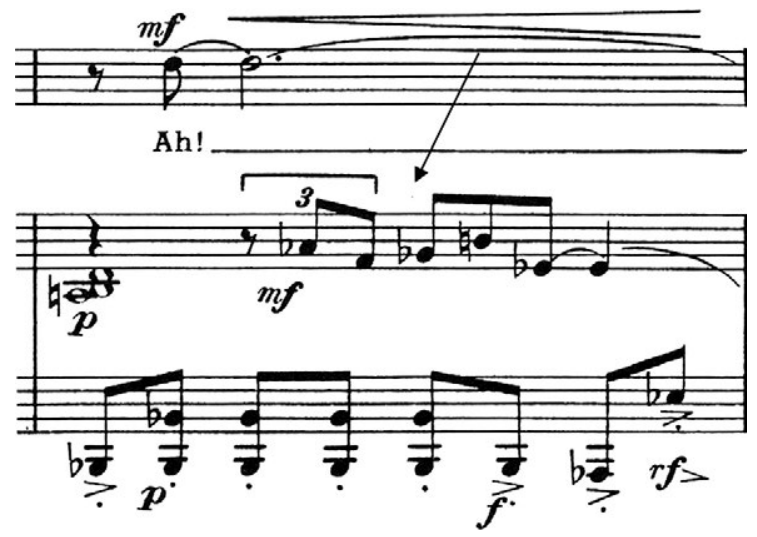

Villa-Lobos. Iara, compasso 86.

Éditions Max Eschig, Paris, 1929.

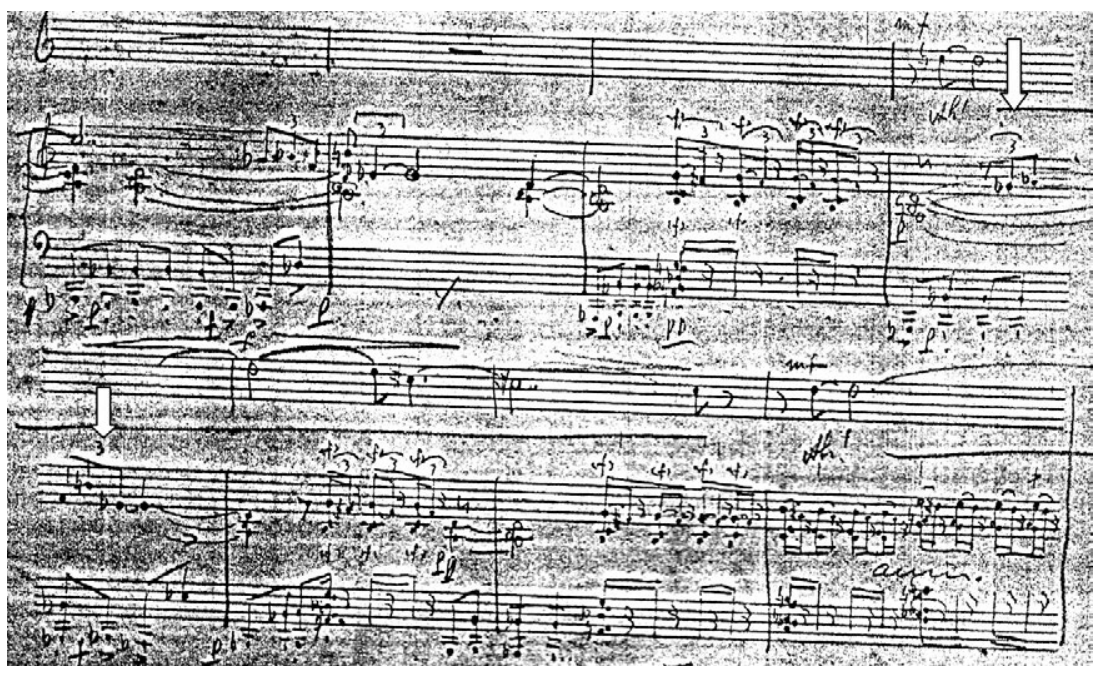

Villa-Lobos. Iara, compassos 83-9.

Manuscrito, Museu Villa-Lobos, Rio de Janeiro. 
7. A pausa no manuscrito analisado tem metade do valor da pausa na edição Max Eschig.

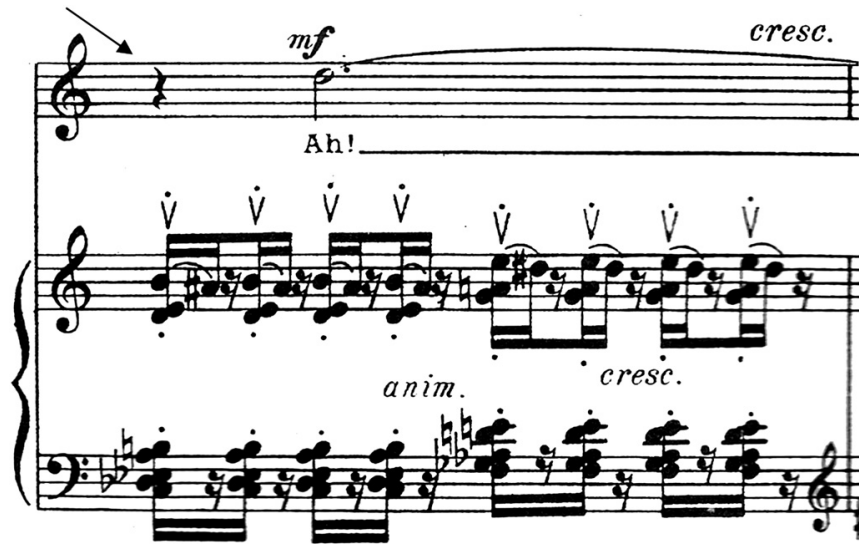

Villa-Lobos. Iara, compasso 89.

Éditions Max Eschig, Paris, 1929.

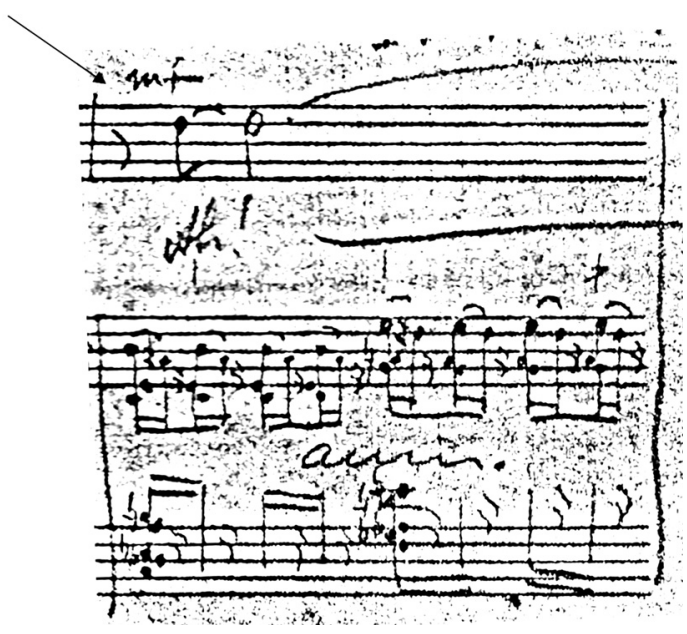

Villa-Lobos. Iara, compasso 89.

Manuscrito, Museu Villa-Lobos, Rio de Janeiro. 
8. No manuscrito assinalado, a oitava sobre a nota si bemol continua nesses dois compassos abaixo.

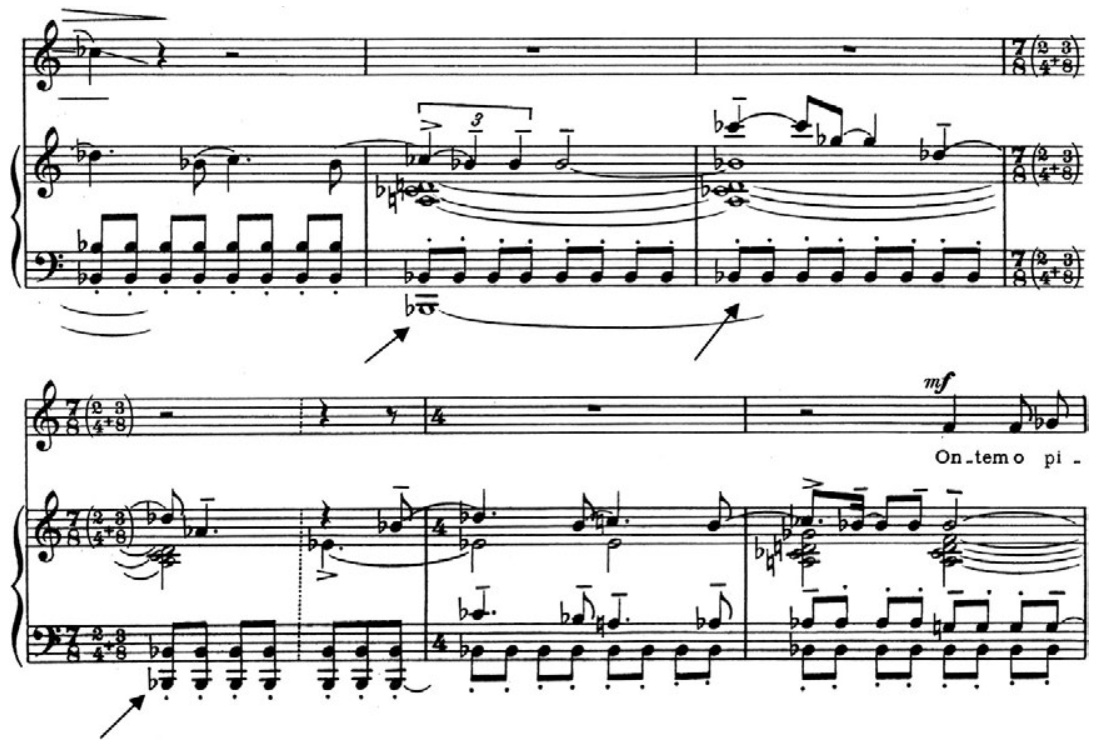

Villa-Lobos. Iara, compassos 93-8.

Éditions Max Eschig, Paris, 1929.

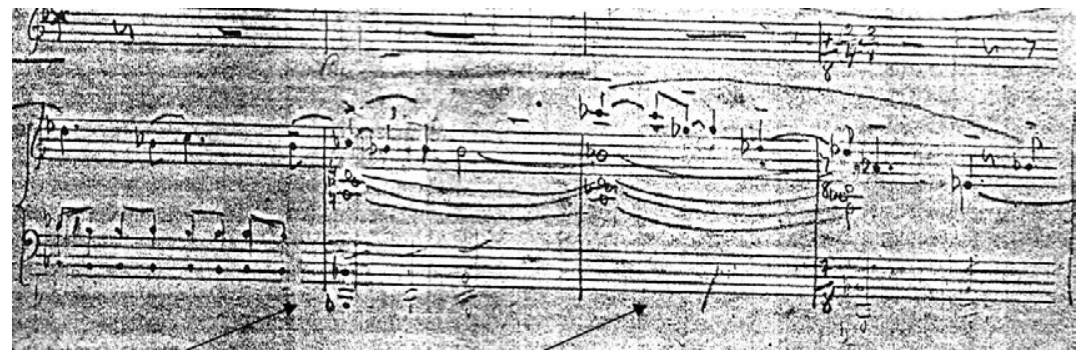

Villa-Lobos. Iara, compassos 93-6.

Manuscrito, Museu Villa-Lobos, Rio de Janeiro. 


\section{Modinhas e Canções - primeiro caderno}

Tabela 5. Modinhas e Canções v.I, data da composição/publicação, gênero e texto

\begin{tabular}{l|l|l|l}
\hline $\begin{array}{l}\text { Canção do } \\
\text { marinheiro }\end{array}$ & $\begin{array}{l}\text { 1936,1957, Éditions } \\
\text { Max Eschig }\end{array}$ & canção & $\begin{array}{l}\text { versos recolhidos por Gil } \\
\text { Vicente }\end{array}$ \\
\hline $\begin{array}{l}\text { Lundu da } \\
\text { marquesa de } \\
\text { Santos }\end{array}$ & $\begin{array}{l}\text { 1940, 1957, Éditions } \\
\text { Max Eschig }\end{array}$ & $\begin{array}{l}\text { lundu } \\
\text { (modinha) }\end{array}$ & Viriato Correa \\
\hline Cantilena & $\begin{array}{l}\text { 1938, 1957, Éditions } \\
\text { Max Eschig }\end{array}$ & canção & $\begin{array}{l}\text { letra e melodia recolhidas } \\
\text { por Sodré Vianna }\end{array}$ \\
\hline A gatinha parda & $\begin{array}{l}\text { 1937, 1957, Éditions } \\
\text { Max Eschig }\end{array}$ & canção & tema popular século XIX \\
\hline $\begin{array}{l}\text { Remeiro de São } \\
\text { Francisco }\end{array}$ & $\begin{array}{l}\text { 1941, 1957, Éditions } \\
\text { Max Eschig }\end{array}$ & canção & $\begin{array}{l}\text { letra e melodia recolhidas } \\
\text { por Sodré Vianna }\end{array}$ \\
\hline Nhapopé & $\begin{array}{l}\text { 1935, 1957, Éditions } \\
\text { Max Eschig }\end{array}$ & canção & antiga melodia popular \\
\hline Evocação & $\begin{array}{l}\text { 1933, 1957, Éditions } \\
\text { Max Eschig }\end{array}$ & canção & Sylvio Salema \\
\hline
\end{tabular}

Todas as Modinhas e Canções v.I foram compostas no Rio de Janeiro.

Segundo Elias (1995, p.244), a modinha é uma

composição de inspiração melódica muito acentuada e carregada de nostalgia. Produto de importação portuguesa, mote ou moda, a modinha é um produto urbano. Ela apresenta várias facetas e é influenciada pelo canto português, pela valsa e pelas árias italianas. $\mathrm{O}$ emprego de quiálteras e a divisão irregular de tempo são as principais características rítmicas às quais Villa-Lobos juntou certas soluções harmônicas de grande beleza.

Tarasti (1995, p.232) classifica o tonalismo das coleções de Modinhas e Canções como um deslizamento do compositor em direção a um romantismo nacionalista. Segundo Wright (1992, p.80), o principal objetivo do compositor nesse conjunto está demonstrado pelo uso ou implicação frequente da palavra "evocação". 
A clássica canção Lundu da marquesa de Santos é uma evocação do espírito de 1822 (ano da independência do Brasil), enquanto a canção Evocação é um esboço para uma canção popular contemporânea (1933). A Canção do marinheiro, um lamento em estilo ibérico do século XVI, supostamente evoca os pensamentos de um marinheiro do tempo das caravelas de Cabral em 1500.

Wright continua, afirmando que "esse tipo de evocação foi grandemente expandido na música que Villa-Lobos escreveu em 1937 para o filme O descobrimento do Brasil, que tratava do mesmo assunto".

De acordo com o Museu Villa-Lobos, as primeiras audições das obras desse caderno foram as seguintes:

25.7.42, Rio de Janeiro - Salão Leopoldo Miguez da ENM. Canção do marinheiro, Lundu da marquesa de Santos e Remeiro de São Francisco. Maria Figueiró Bezerra, canto; Geraldo Rocha Bezerra, pf.

28.1.45, Nova York - Museu de Arte Moderna. Canção do marinheiro e Lundu da marquesa de Santos. Olga Praguer Coelho, canto; Carol Longone, pf.

\section{Canção do marinheiro}

Rio de Janeiro, 1936.

\section{Texto}

Segundo Wright (1992, p.128), essa modinha foi reutilizada na íntegra na canção Lost da ópera Magdalena, que segundo esse autor estabelece um ponto de convívio entre o brasilianismo e o universalismo, criando uma verdadeira síntese de estilos, "a genuinely cross-cultural work". Villa-Lobos utiliza também nessa ópera o Coral (Canto do sertão) da Bachianas Brasileiras no4 e o Remeiro de São Francisco, também do primeiro caderno das Modinhas e Canções. 
De acordo com Heitor Megale, titular de Filologia Portuguesa da Universidade de São Paulo, a edição da Max Eschig atribui equivocadamente essas canções a Gil Vicente. Segundo Megale, trata-se de duas cantigas de Lourenço. Abaixo, a transcrição do texto de Megale, contido no CD Água de fonte (Selo Editorial Clássicos, 2008):

\section{Lourenço: de jogral a trovador no século XIII}

Embora continue controvertida a origem desse jogral que competiu com trovadores de seu tempo, não se discute o mérito documental de seu variado repertório de 18 cantigas de amor, amigo e atenção. Tavani, certamente o especialista que mais aprofundou a pesquisa em torno da figura e da obra de Lourenço, considera-o um dos poetas mais singulares e interessantes da segunda metade do século XIII no ambiente português da corte de Afonso III e no castelhano da de Afonso X, o sábio. Seu talento o emancipou da condição de assalariado de Johan Garcia de Guilhade, o que lhe valeu não poucas implicâncias e insultos. $\mathrm{O}$ anonimato, via de regra, escondia contendores, mas entre nomes conhecidos de trovadores com quem trocou farpas, além de Guilhade, figuram Johan Peres d'Avoin, Johan Soares Coelho, Pedro Amgio de Sevilha, Pero Gomez Barroso e Rodrigu'Eanes Redondo. Suas cantigas estão na Biblioteca Nacional de Lisboa e na, da Vaticana, tendo sido editadas por Nunes e Machado, além da edição exclusiva de sua obra por Giuseppe Taviani.

São sete suas cantigas de amigo, entre as quais as duas agora fixadas na música de Villa-Lobos, na brilhante execução da soprano Cláudia Riccitelli. Hunha moça namorada é uma cantiga que inova com a apresentação do motivo do lamento da amiga, a cada estrofe, e Três moças cãtavã mescla a expressão do cantar de amor, mha senhor, à cantiga de amigo. Equivocadamente, o editor da partitura de 1957, Max Eschig, a quem Villa-Lobos cedeu direitos, atribuiu essas cantigas de Lourenço a Gil Vicente, como versos recolhidos pelo pai da dramaturgia portuguesa de uma só composição, que estranhamente junta a primeira estrofe de cada uma das cantigas. 
Como se pode verificar, ao longo das duas cantigas, não há mínima referência a mar nem a marinheiro.

Textos originais de Lourenço:

Hunha moça namorada (excerto)

Dixia huu cantar

d'amor

E diss'ella nostro

senhor

Oi'eu fosse

auenturada

Que oiss'o meu amigo

Com'eu este cantar

Digo

(...etc.)

(B 1261; V.866, Nunes, Amigo, v. II, 473)

Três moças cãtavã d'amor (excerto)

Mui fremosinhas

pastores

Mui coytadas dos

amores

E diss'end'unha mha

senhor

Dized'amigas comigo

O cantar do meu

amigo

(B 1262; V. 866, Nunes, Amigo, v. II, 474)

Canção do marinheiro, Éditions Max Eschig, 1957

Rio de Janeiro, 1936.

Música de Villa-Lobos. 
Texto publicado na partitura:

Hunha moça namorada

Dizia hum cantar d'amôr

E diss'ella

Nostro senhor, oj'eu fosse aventurada

Que visse o meu amigo como eu

Este cantar digo,

Ah! Três moças cantavam d'amôr

Mui fremosinhas pastoras

Mui coytadas dos amores

E diss'endunha m'há senhor:

Dizede, amigas,

Comigo o cantar do meu amigo...

Ah! Ah! Ah!

\section{Estrutura formal e harmônica}

Essa canção revela um maneirismo ibérico, bem perceptível por meio dos grandes melismas do canto. Temos exemplos dessa ornamentação característica da música espanhola em diversos compassosver compassos 6, 9, 17, 23, 25, 31, 40, 45, 49 a 54 .

Os versos são articulados pelas notas longas do canto. A sílaba "Ah!" articula a forma apresentando uma nota longa que dura quatro compassos. No compasso 28 inicia-se, assim, o segundo verso do texto, coincidentemente a segunda cantiga de Lourenço e a segunda parte da canção. A coda da canção inicia-se em 48 e também está construída sobre a sílaba "Ah!”, repetida três vezes, enfaticamente.

A primeira parte da canção polariza a nota ré, caracterizando o modo frígio na melodia vocal (ré-mi b-fá-sol-lá-si b-dó-ré).

Há uma intenção musical diferente na segunda parte, porém a melodia dos compassos 38-41 remete aos compassos iniciais. $\mathrm{O}$ acompanhamento ostinato do piano é um dos elementos de coerência da canção e caracteriza bem a estética pré-tonal da canção.

No manuscrito, versão orquestral, há uma sugestão de corte do compasso 18 ao compasso 28. 


\section{Aspectos interpretativos}

Sugerimos abaixo uma aplicação do pedal nas duas configuraçõeschave da canção.

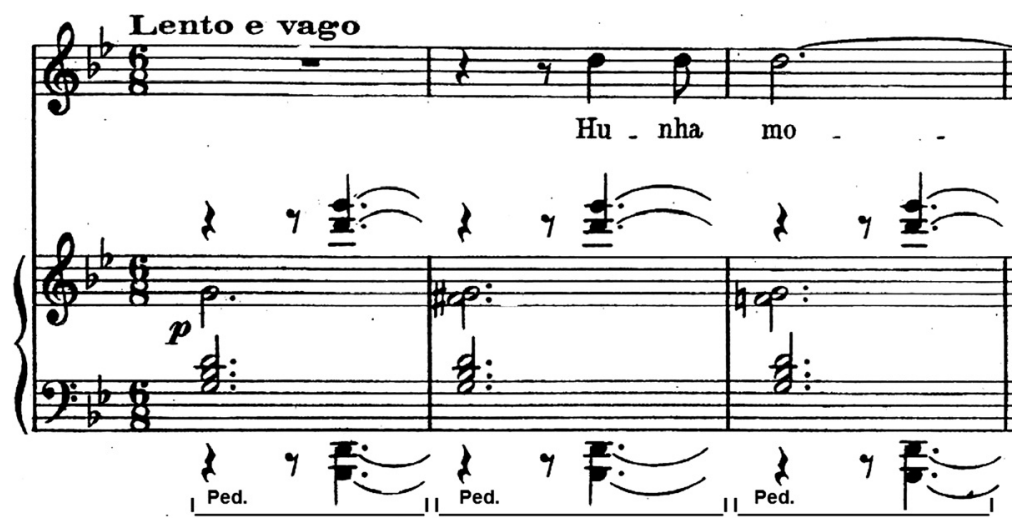

Villa-Lobos. Canção do marinheiro, sugestão de pedal, compassos 1-3.

Éditions Max Eschig, Paris, 1957.
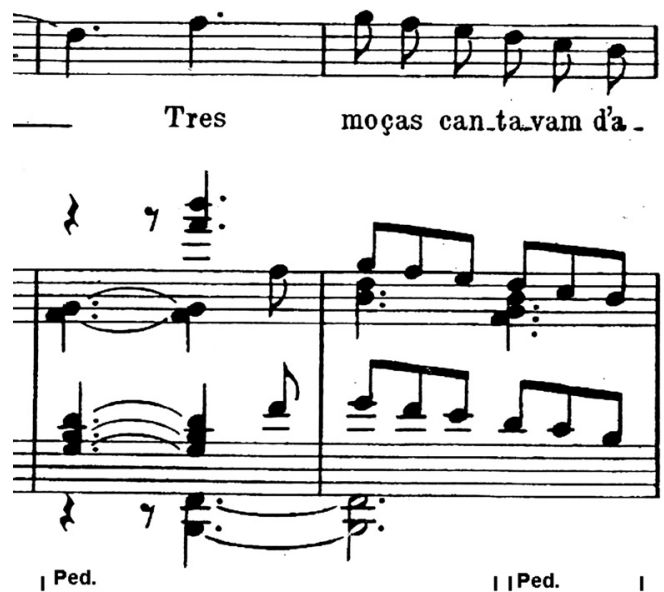

Villa-Lobos. Canção do marinheiro, sugestão de pedal, compassos 28-9. Éditions Max Eschig, Paris, 1957. 


\section{Edição e manuscritos}

1. As notas assinaladas não correspondem às notas da transcrição para orquestra.

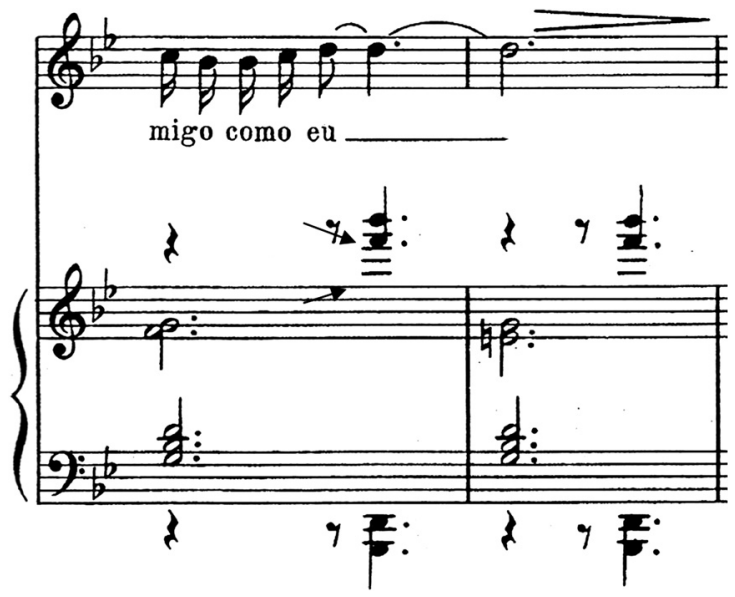

Villa-Lobos. Canção do marinheiro, compassos 20-1.

Éditions Max Eschig, Paris, 1957.
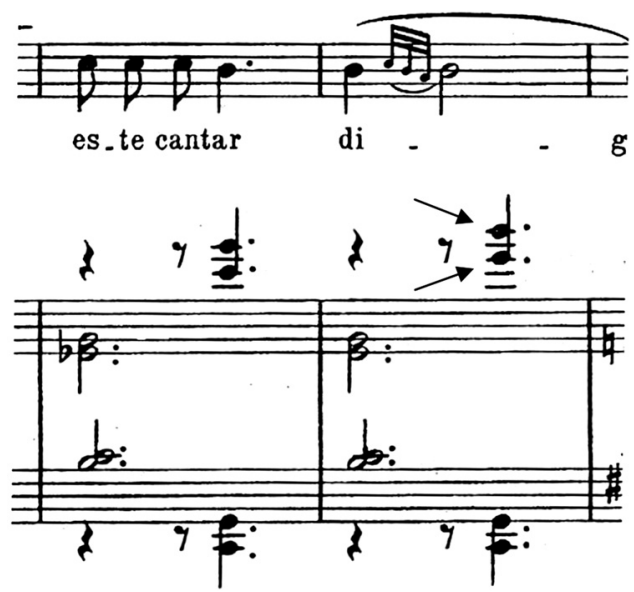

Villa-Lobos. Canção do marinheiro, compassos 22-3. Éditions Max Eschig, Paris, 1957. 
Clarineta. I. cançäo do marinheiro. H.VIIIF-LOBOS $(\varepsilon m$ sib)

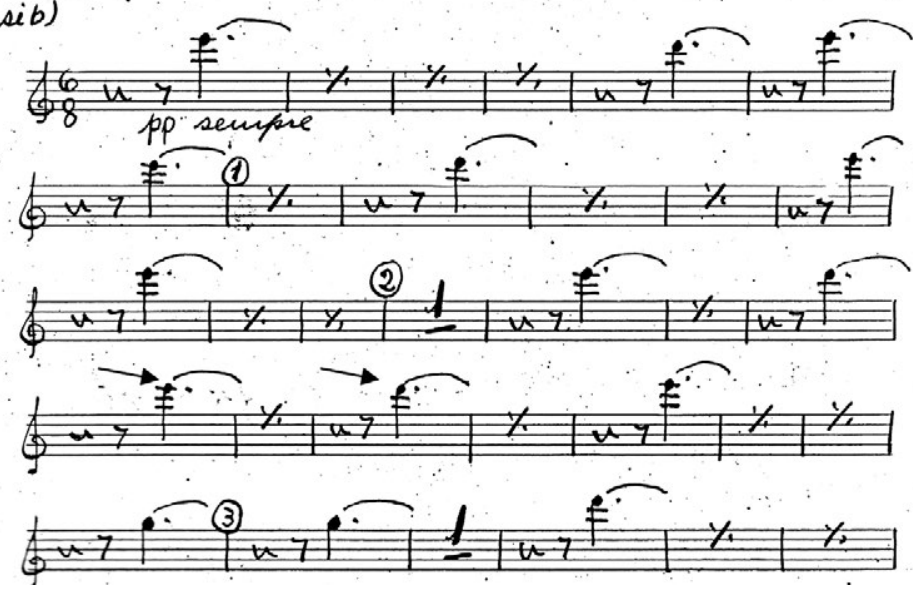

\section{$\underline{F l_{\text {Aut }}}$}

MODINHAS E LANUUES H.VIIIA-LOBOS I. CANĢấo Do marinhEiro

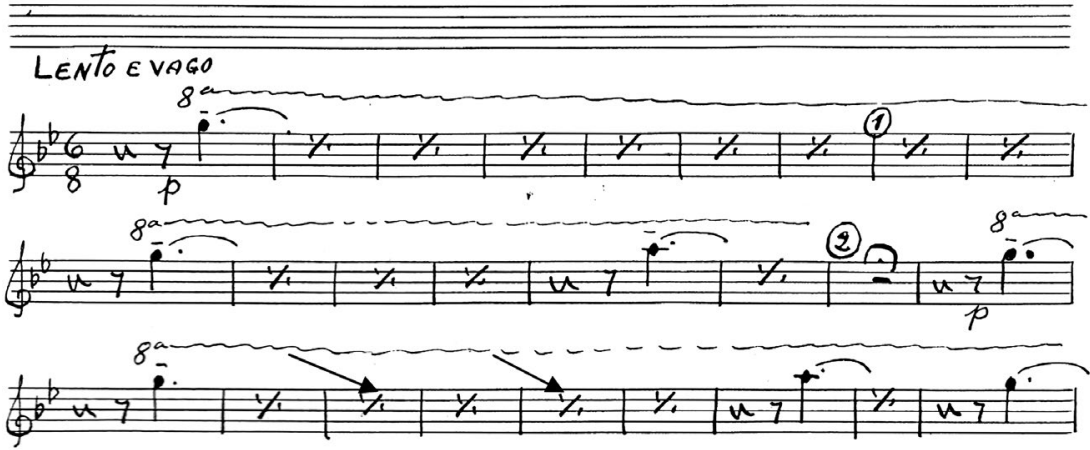

Villa-Lobos. Canção do marinheiro.

Manuscritos da versão orquestral, Museu Villa-Lobos, Rio de Janeiro, 1936. 


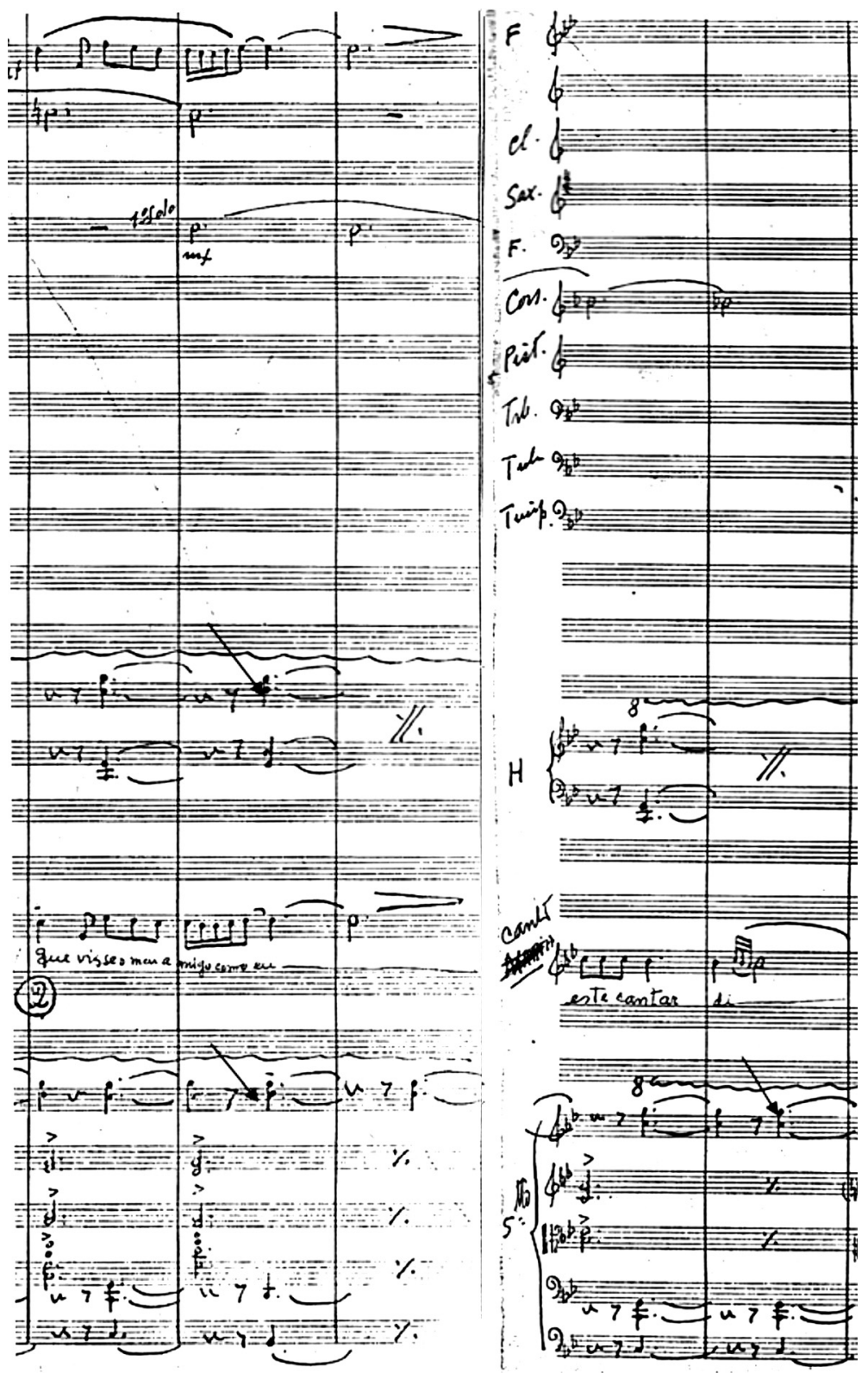

Villa-Lobos. Canção do marinheiro, compassos 19-23.

Grade orquestral do manuscrito, Museu Villa-Lobos, Rio de Janeiro, 1936. 
2. Na versão orquestral encontramos a politonalidade ré maior/ré menor, como em todos os acordes de ré durante a canção. Na edição da Max Eschig as duas notas fá estão alteradas ascendentemente.

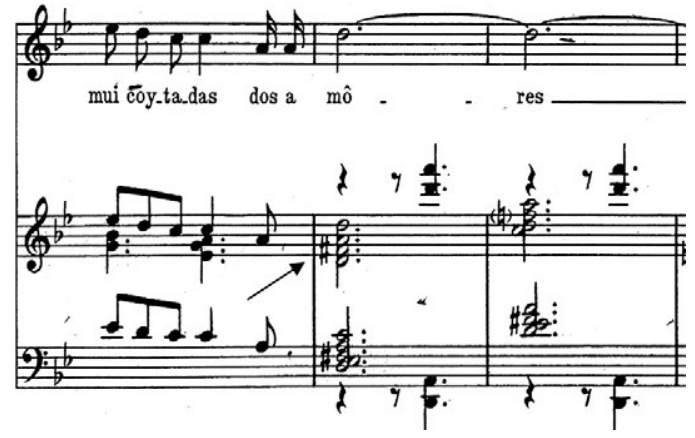

Villa-Lobos. Canção do marinheiro, compassos 35-7. Éditions Max Eschig, Paris, 1957.

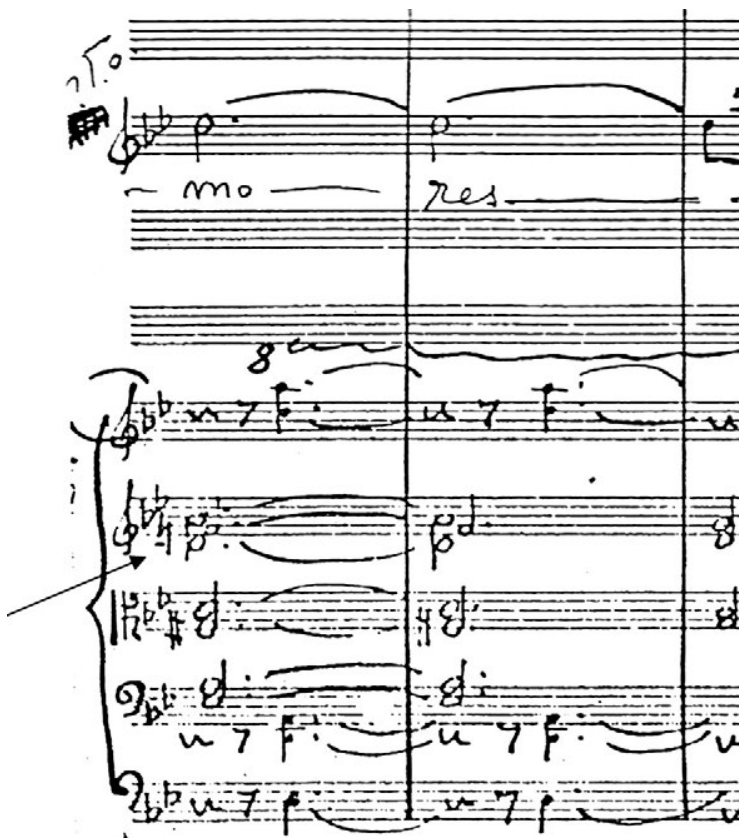

Villa-Lobos. Canção do marinheiro, compassos 36-7.

Grade orquestral do manuscrito, Museu Villa-Lobos, Rio de Janeiro, 1936. 


\section{Lundu da marquesa de Santos}

Rio de Janeiro, 1940.

\section{Texto}

No subtítulo da canção podemos ler "Evocação da época de 1822”. Assim, a redação original não será revisada.

Minha flôr idolatrada

Tudo em mim é negro e triste

Vive minh'alma arrasada

O'Titilia

Desde o dia em que partiste

Este castigo tremendo já minh'alma não resiste, Ah!

Eu vou morrendo, morrendo

Desde o dia em que partiste

Tudo em mim é negro e triste

Vive minh'alma arrasada,

Ó Titilia!

Desde o dia em que partiste

Tudo em mim é negro e triste

Este castigo tremendo tremendo

Ó Titilia

Minha flôr idolatrada

Tudo em mim é negro e triste

Vive minh'alma arrasada

Ó Titilia!

Desde o dia em que partiste,

Este castigo tremendo já minh'alma não resiste, Ah!

Eu vou morrendo, morrendo

Desde o dia em que partiste.

A construção do texto é típica da época evocada e algumas palavras não são mais usadas no português atual. Por exemplo: minh'alma, flôr com acento circunflexo, tratamento em tu (partiste). 


\section{Estrutura formal e harmônica}

Lundu, segundo Tarasti (1995, p.232), "é uma dança que foi importada pelos negros de Angola e que se espalhou pelo Brasil. Mas havia também versões mais refinadas de lundus que se dançavam nos salões burgueses", como é o caso do Lundu da marquesa de Santos.

Introdução. Allegretto: compassos 1 a 4.

Seção A. Moderato: compassos 5 a 20. Frases/períodos clássicos de quatro e oito compassos. Tonalidade: si b maior.

Seção B. Più mosso: compassos 21 a 36. Frases/períodos irregulares de cinco, três, três e cinco compassos. Tonalidade: ré menor.

Seção A. Tempo I. Reprise exata do material apresentado no início da canção: compassos 37 a 52 mais um compasso para acorde de finalização. Tonalidade: si b maior.

A característica simples e tonal da modinha do século XIX é um elemento de coesão e coerência na composição de Villa-Lobos. O compositor emprega uma harmonia simples e funcional, explorando funções principais de tônica/subdominante/dominante.

\section{Aspectos interpretativos}

Abaixo, sugestão de dedilhado para a introdução do lundu.

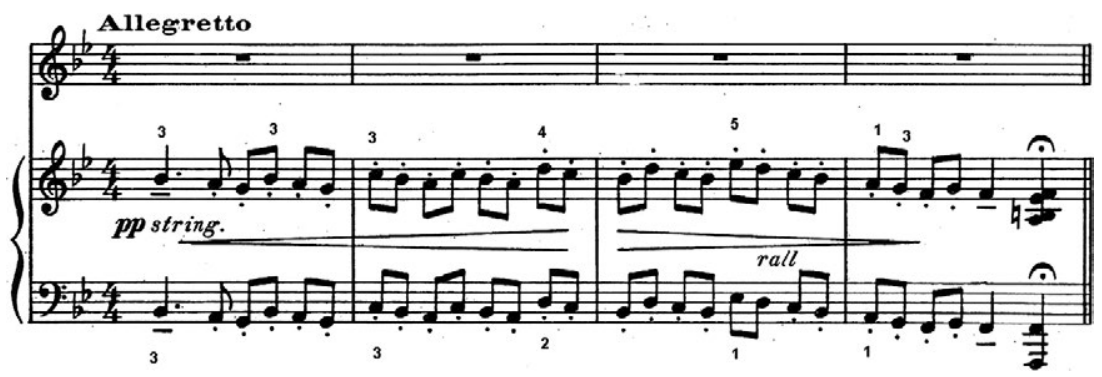

Villa-Lobos. Lundu da marquesa de Santos, dedilhado da introdução. Éditions Max Eschig, Paris, 1957. 


\section{Edição e manuscritos}

1. Falta a ligadura que encontramos no compasso 10 e nos manuscritos orquestrais.

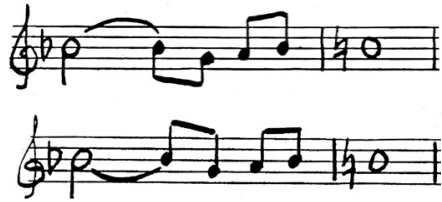

Villa-Lobos. Lundu da marquesa de Santos, parte da trompa em fá, compassos 10 e 42.

Manuscrito, Museu Villa-Lobos, Rio de Janeiro.
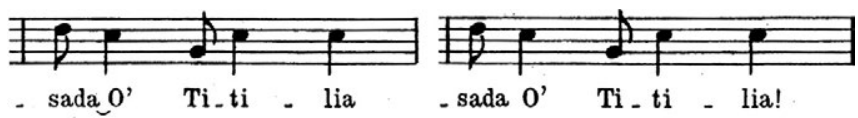

- sada 0' Ti - ti - lia!
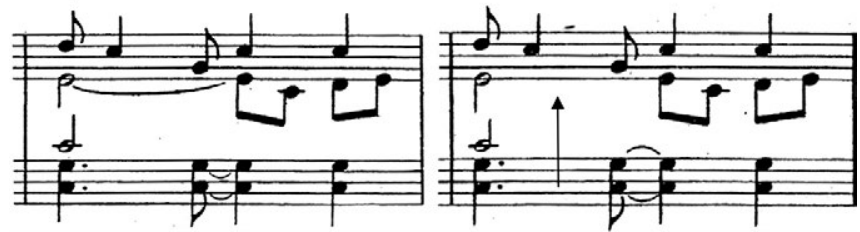

Villa-Lobos. Lundu da marquesa de Santos, compassos 10 e 42.

Éditions Max Eschig, Paris, 1957.

2. Na edição da Max Eschig, a parte do canto possui uma indicação de rallentando que contradiz a parte do piano, que possui uma indicação de stringendo.
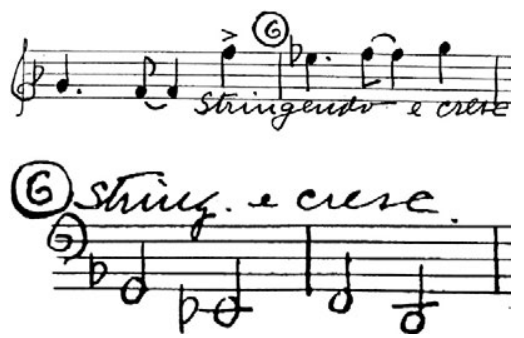

Villa-Lobos. Lundu da marquesa de Santos, partes do primeiro violino e do violoncelo, compassos 30-1.

Manuscrito, Museu Villa-Lobos, Rio de Janeiro. 


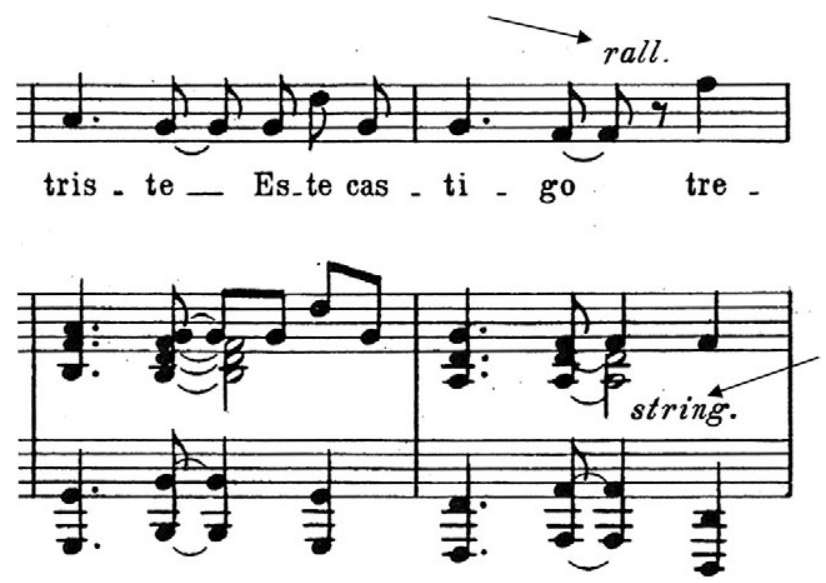

Villa-Lobos. Lundu da marquesa de Santos, compassos 30-1. Éditions Max Eschig, Paris, 1957.

\section{Cantilena}

Rio de Janeiro, 1938.

\section{Texto}

O Rei mandou me chamá

O Rei mandou me chamá

P'ra casar com sua fia

Só de dóte ele me dava

Só de dóte ele me dava

Óropa França Bahia

Me alembrei do meu ranchiho,

Da roça do meu feijão

O rei mandou me chamá

Ai! Seu Rei não quero não.

Ai! Seu Rei não quero não. 
O texto não deve ser revisado, por se tratar de um texto/canto recolhido diretamente na região do Recôncavo do estado da Bahia. Há várias pronúncias características da linguagem de época dos negros escravos, tais como:

$$
\begin{gathered}
\text { Chamá = chamar } \\
\text { P'ra = Para } \\
\text { Fia = Filha } \\
\text { Óropa = Europa } \\
\text { Alembrei = Lembrei }
\end{gathered}
$$

\section{Estrutura formal e harmônica}

Segundo Tarasti (1995, p.232), "cantilena representa o pentatonismo típico africano que o compositor usou frequentemente na sua obra para piano”. Há uma nota bordão, a nota dó, tocada na região grave do teclado, que perdura por toda a canção, reforçando o caráter circular e pré-tonal da canção.

A canção é construída sobre o modo jônio (dó-ré-mi b-fá-sol-lá b-si b-dó).

Há uma ausência total da nota sensível, no caso a nota si bequadro, o que poderia aproximar a canção da tonalidade de dó menor.

\section{Aspectos interpretativos}

Antes de iniciar a canção, segurar a nota dó grave com o pedal harmônico, objetivando um grande legato de pedal. Assim, não haverá interrupção da ressonância dos harmônicos em nenhum momento da execução.

Sugerimos também uma mudança de toque pianístico do compasso 28 ao compasso 38, quando o canto apresenta o tema com bouche fermée. Aplicar um toque mais leve, non legato (com pedal), para uma mudança de sonoridade compatível com o canto. 


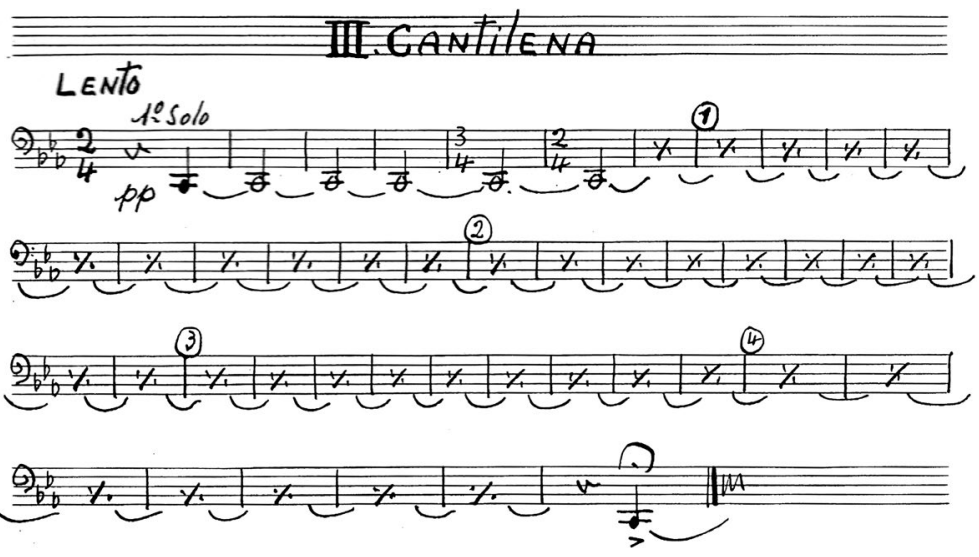

Villa-Lobos. Cantilena, parte do contrabaixo.

Manuscrito, Museu Villa-Lobos, Rio de Janeiro.

\section{Edição e manuscritos}

1. A nota dó da mão esquerda do piano deveria ser ligada à próxima.
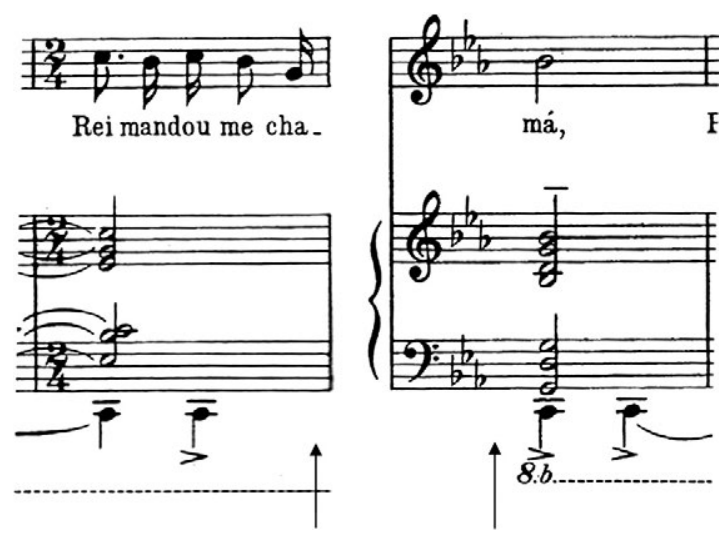

Villa-Lobos. Cantilena, compassos 6-7.

Éditions Max Eschig, Paris. 


\section{A gatinha parda}

Rio de Janeiro, 1937.

\section{Texto}

Miau! Miau!

A minha gatinha parda

Em janeiro me fugiu

Quem achou minha gatinha,

Você sabe? Você sabe? Você viu?

Miau!

Texto muito simples, sobre um tema popular infantil do século XIX, de caráter eminentemente lúdico.

\section{Estrutura formal e harmônica}

A forma musical é singela, estrófica simples. A simplicidade do texto reproduz-se na música, de inspiração claramente tonal. A canção é uma invenção a duas vozes para piano e voz, com duas linhas melódicas baseadas sobre o acorde de tônica e sobre o acorde da dominante.

Da mesma maneira que no Lundu da marquesa de Santos, VillaLobos associa o século XIX aos princípios fundamentais da harmonia tradicional. Caráter lúdico, scherzando.

Tonalidade: mi b maior.

\section{Aspectos interpretativos}

Sugestão de dedilhados úteis para a execução da parte pianística da canção. 

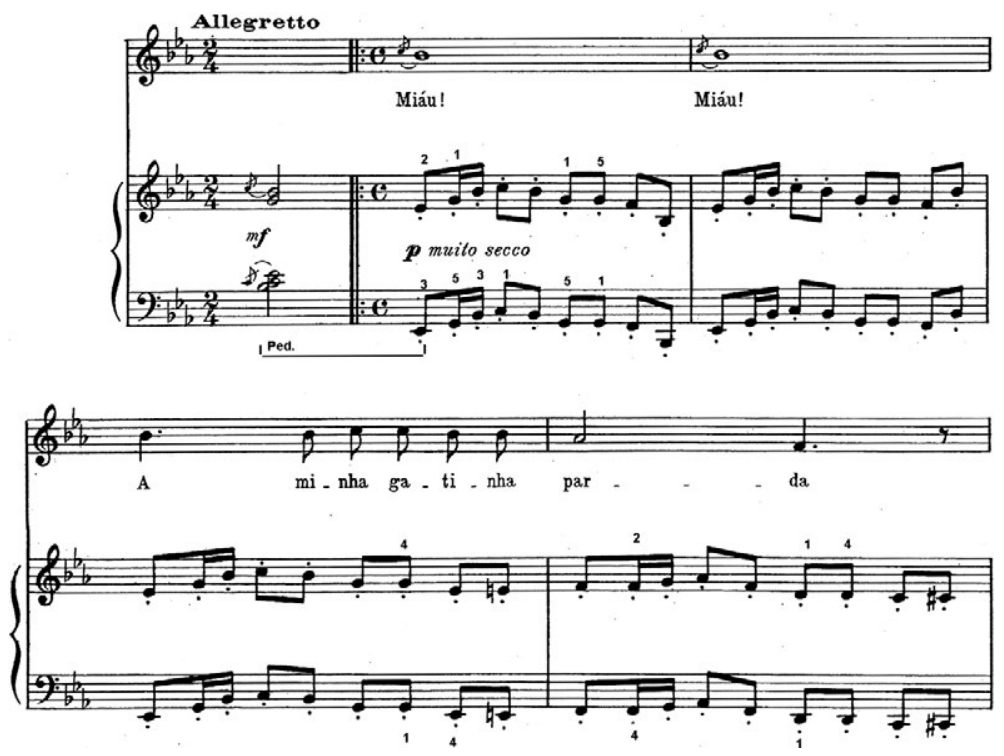

Villa-Lobos. A gatinha parda, compassos iniciais.

Éditions Max Eschig, Paris.

\section{Edição}

Não foram encontrados erros editoriais na partitura dessa canção.

\section{Remeiro de São Francisco}

Rio de Janeiro, 1941.

\section{Texto}

Schê!

Oh!

Lê lê diá!

Que é que tem cara vermeia?

Meu sinhô que me vendeu

Com toda carregação

Oh! Lê lê diá!

A canção é baseada no canto dos mestiços que trabalhavam no rio São Francisco e seu material foi coletado por Sodré Vianna. Da 
mesma maneira que a canção Cantilena, o texto não será revisado para não adulterar suas características regionais.

Explicação aproximada do significado da linguagem regional empregada:

Schê: onomatopeia inicial que traduz o som do remeiro nas águas do rio São Francisco.

Oh! Lê-lê-diá é uma figura de linguagem que evoca o canto dos remeiros.

Que é que tem cara vermeia $=$ Quem é que tem rosto vermelho.

Meu sinhô que me vendeu $=$ Meu senhor (de escravos) que me vendeu.

Com toda carregação = Com todas as mercadorias.

\section{Estrutura formal e harmônica}

À maneira da Cantilena, essa canção explora o ostinato no acompanhamento instrumental, com uma interrupção nos compassos 9 e 10 que, em vez de interromper a monotonia do movimento dos remeiros, o intensifica, criando uma expectativa para sua volta no compasso 11.

Tonalidade: fá maior.

\section{Edição e manuscritos}

A mão esquerda do pianista tem o mesmo movimento do compasso anterior, ou seja, a nota tocada pelo polegar é dó e não si bemol.

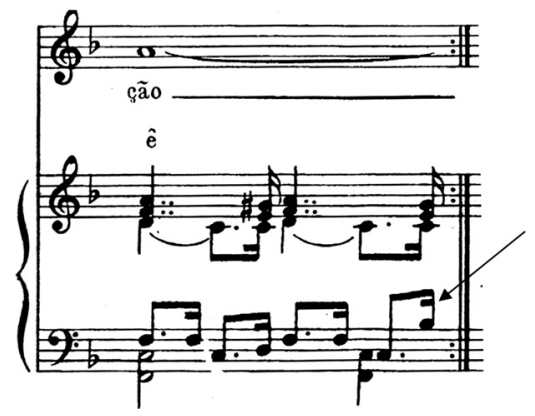

Villa-Lobos. Remeiro de São Francisco, compasso 12.

Éditions Max Eschig, Paris, 1957. 


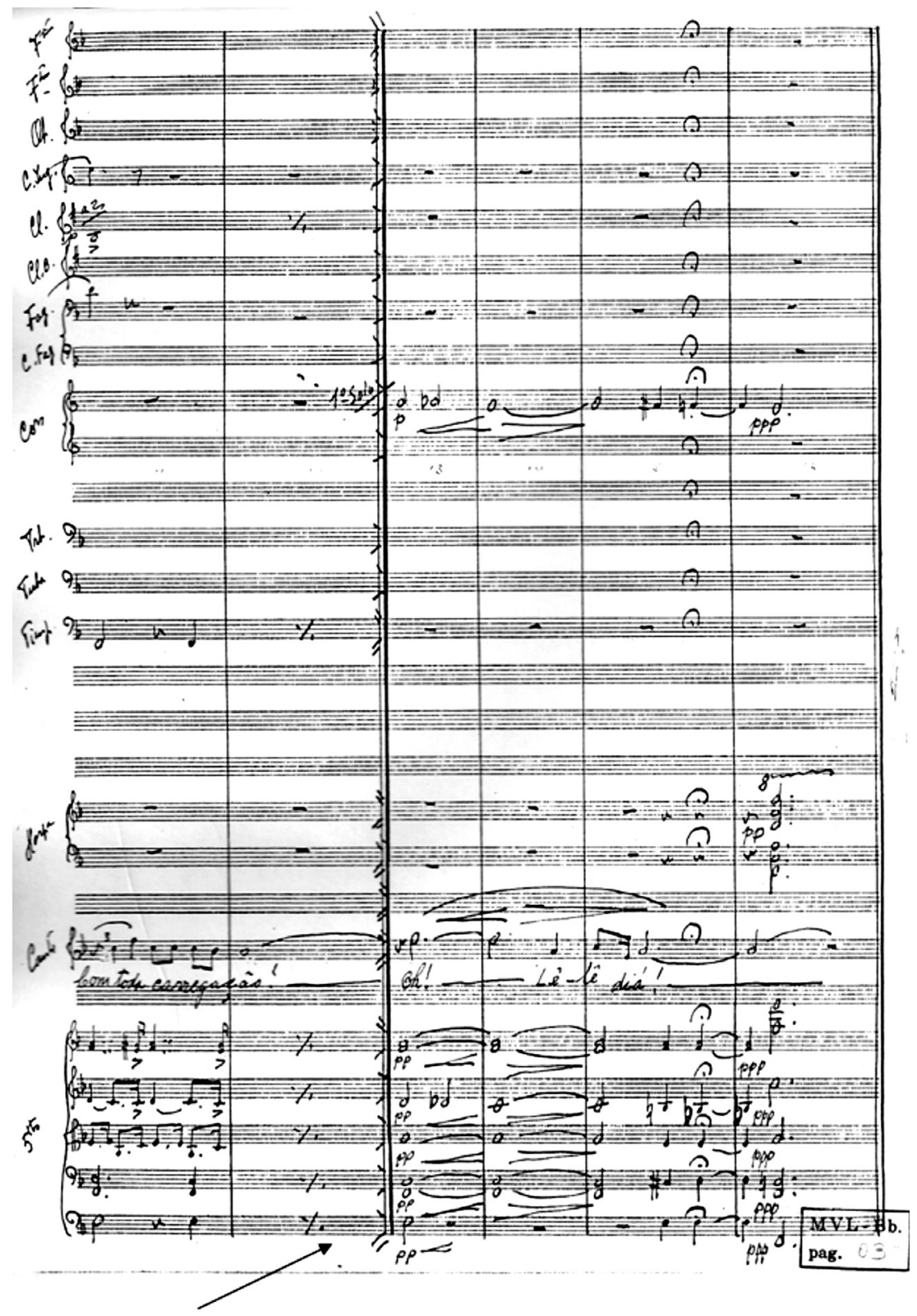

Villa-Lobos. Remeiro de São Francisco.

Manuscrito da grade orquestral, Museu Villa-Lobos, Rio de Janeiro. 


\section{Nhapopé}

Rio de Janeiro, 1935.

\section{Texto}

Ouvi contar certa noite num terreiro quando a lua em farinheiro penerava pelo chão Que Nhapopê quando senta a aza ferida peneirava vae buscar résto de vida no calor de um coração, asa Você é Nhapopê sou teu amante de mim tem fé! vai, resto

Tema e melodia populares que tratam de uma misteriosa ave noturna, o nhapopé, que se alimenta do resto de vida do coração dos mortais.

\section{Estrutura formal e harmônica}

Segundo Tarasti (1995, p.233), "Nhapopé expressa com ardor o pathos da sua parte narrativa e remete à escritura arpejada das Impressões seresteiras ${ }^{8}$ na sua seção intermediária e na introdução do piano".

Intro A B: todas as seções iniciam-se em mi menor e se dirigem à sua dominante si maior.

Uma introdução instrumental no gênero toccata, em andamento animato, prepara a entrada do canto: compassos 1 a 9 .

Seção A. Meno: desenvolvimento do ritmo dançante introduzido pelo piano: compassos 10 a 17 .

Seção B. Lento: Recitativo da voz acompanhado por arpejos instrumentais.

Tonalidade: mi menor.

\section{Aspectos interpretativos}

Sugerimos os seguintes dedilhados para a execução da introdução pianística:

8 Impressões seresteiras é a segunda das quatro obras que compõem o Ciclo Brasileiro para piano solo (1936-1937). 

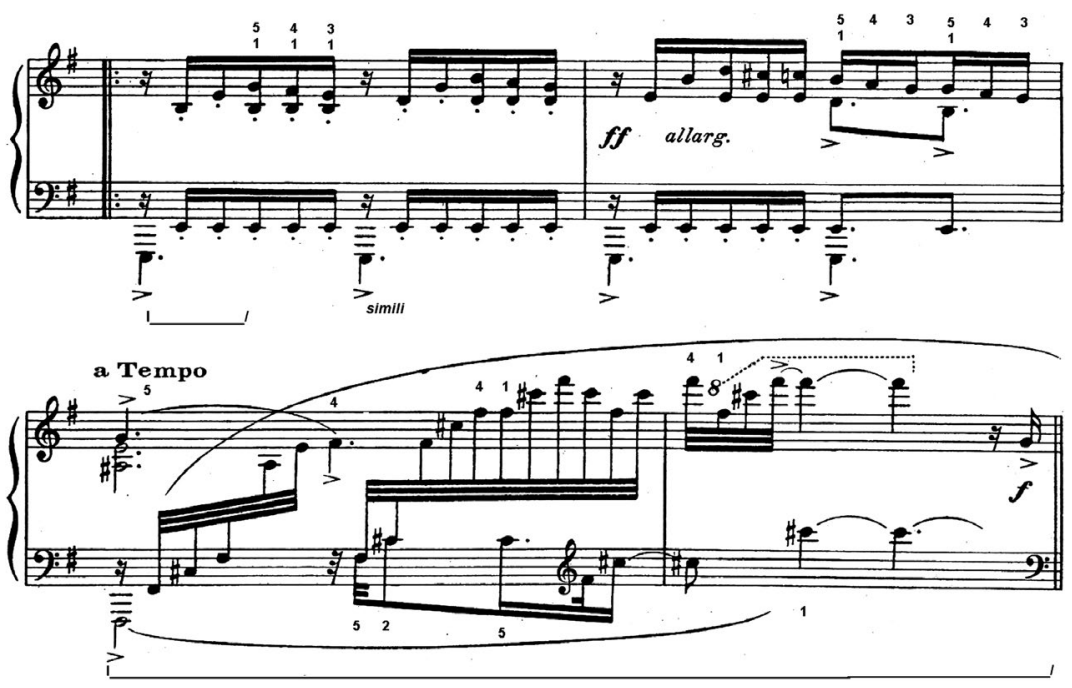

Villa-Lobos. Nhapopé, dedilhado e pedal, compassos 3-6.

Éditions Max Eschig, 1957.

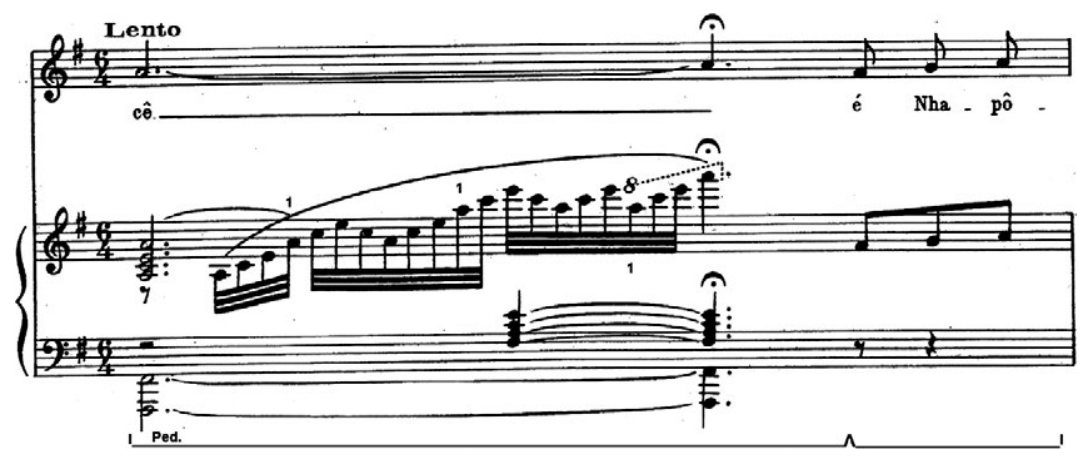

Villa-Lobos. Nhapopé, dedilhado e pedal, compasso 18. Éditions Max Eschig, 1957.

\section{Edição e manuscritos}

Não há erros de edição nessa canção, mas há uma diferença de fraseado na versão orquestral, parte do primeiro violino, que poderá ser aplicada à versão pianística. 


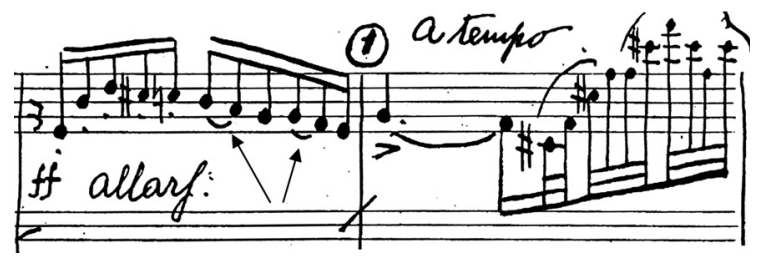

Villa-Lobos. Nhapopé, compasso 4.

Manuscrito da parte do primeiro violino, Museu Villa-Lobos, Rio de Janeiro.

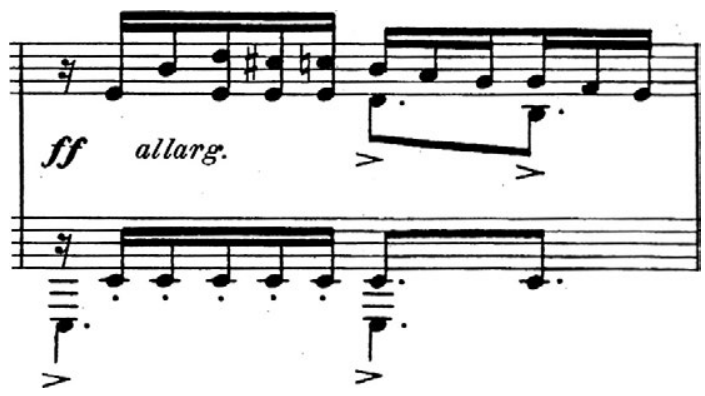

Villa-Lobos. Nhapopé, compasso 4.

Éditions Max Eschig, 1957.

\section{Evocação}

Rio de Janeiro, 1933.

\section{Texto}

Abaixo estão pequenas sugestões de mudança ortográfica das palavras do poema.

Numa noite estrelada de maio

Sua boca beijei a sonhar

E o perfume do seu quente seio

Pouco a pouco me fez delirar.

Eu senti neste doce momento!

Que a vida p'ra mim era o amor de você. 
Nos seus belos cabelos de ouro

Onde o sol se reflete a brilhar

Eu quizera poder meu tesouro,

Entre eles viver ou morrer,

Mas o sonho tão lindo findou-se!

E eu vivo a chorar meu amor por você.

No horizonte azul deste céo

céu

Vivo a recordar meu amor.

Sempre tão distante

Do meu triste olhar

Como a ilusão deste amor, Ah!

Da recordação viverei

E serei feliz em sonhar

Dentro do amor... da ilusão...

Assim, viver, por você.

\section{Estrutura formal e harmônica}

A forma estrutural e tonal da canção é: introdução - AA - BB - coda.

Introdução: Allegro: compassos 1 a 4 em fá menor/maior.

Seção A: Moderato: compassos 5 a 18 em fá maior.

Seção B: Lento: compassos 19 a 34 em fá maior.

Coda: Allegro: compassos 35 a 37 em fá menor/maior.

A canção tem uma estrutura formal e fraseológica simples, típica da música popular urbana do início do século XX.

$\mathrm{Na}$ seção A, temos cinco frases de dois compassos, seguidas de uma frase de quatro compassos que conclui a seção.

A seção B é ainda mais simétrica. Duas frases de dois compassos seguidas de uma frase de quatro compassos para concluir o primeiro período (compassos 19 a 26), seguidas de mais duas frases de dois compassos bastante semelhantes aos compassos 19 a 22 e outra frase variante de quatro compassos para concluir a seção. 


\section{Edição e manuscritos}

1. O acorde da edição está errado: sol - si bemol - ré bequadro - mi bemol. O correto é: sol - si bemol - ré bemol - mi bequadro.

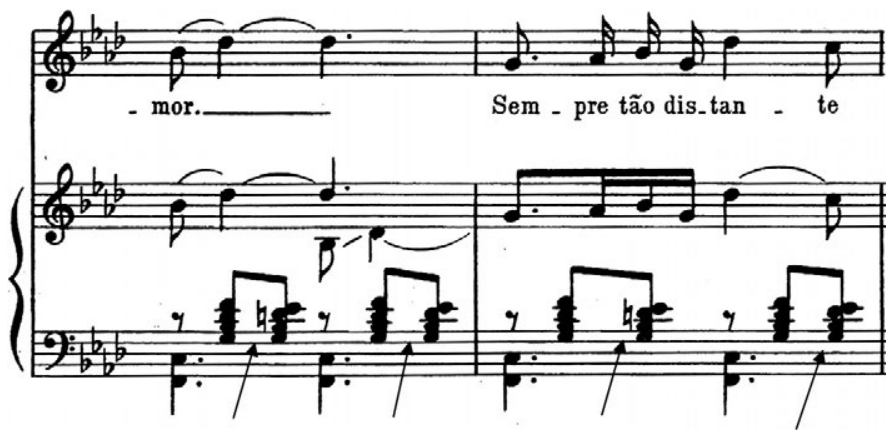

Villa-Lobos. Evocação, compassos 23-4. Éditions Max Eschig, Paris, 1957.

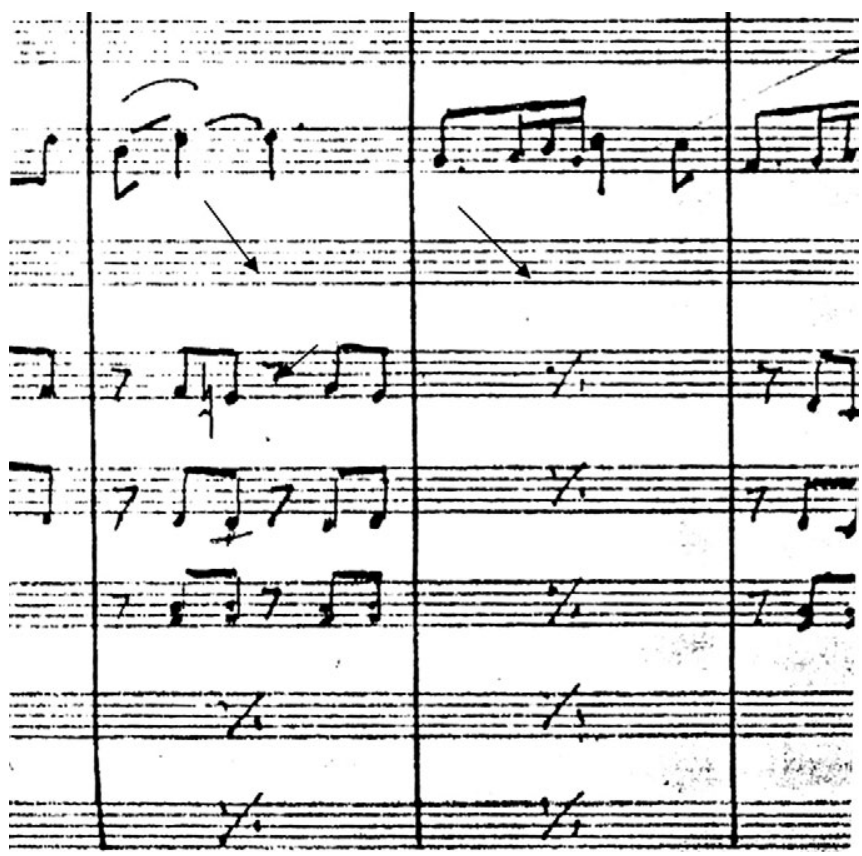

Villa-Lobos. Evocação, compassos 23-4.

Manuscrito da grade orquestral, Museu Villa-Lobos, Rio de Janeiro. 
2. Na edição da Max Eschig falta a sinalização das casas de primeira e segunda vez. Neste mesmo trecho há outro problema: o sinal de repetição é somente D. C. (da capo) ao signo.

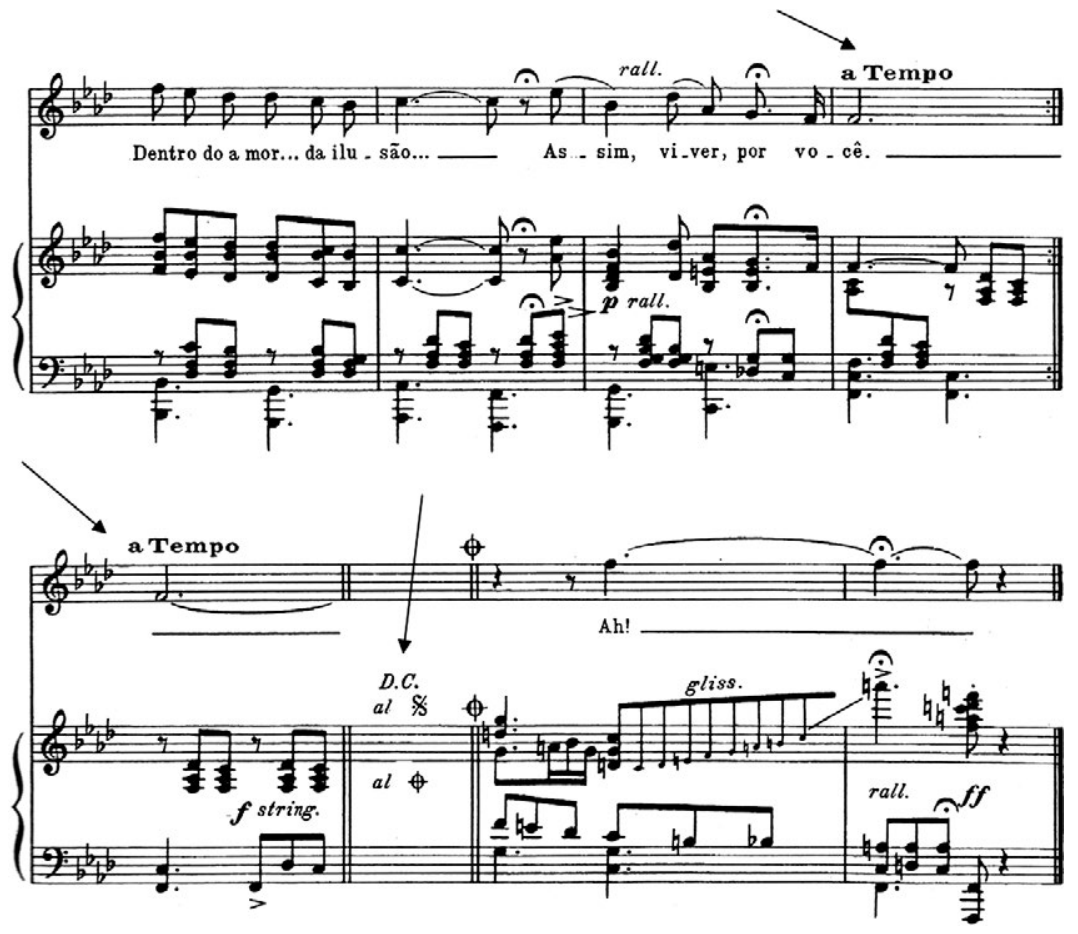

Villa-Lobos. Evocação, compassos 32-6.

Éditions Max Eschig, Paris, 1957. 

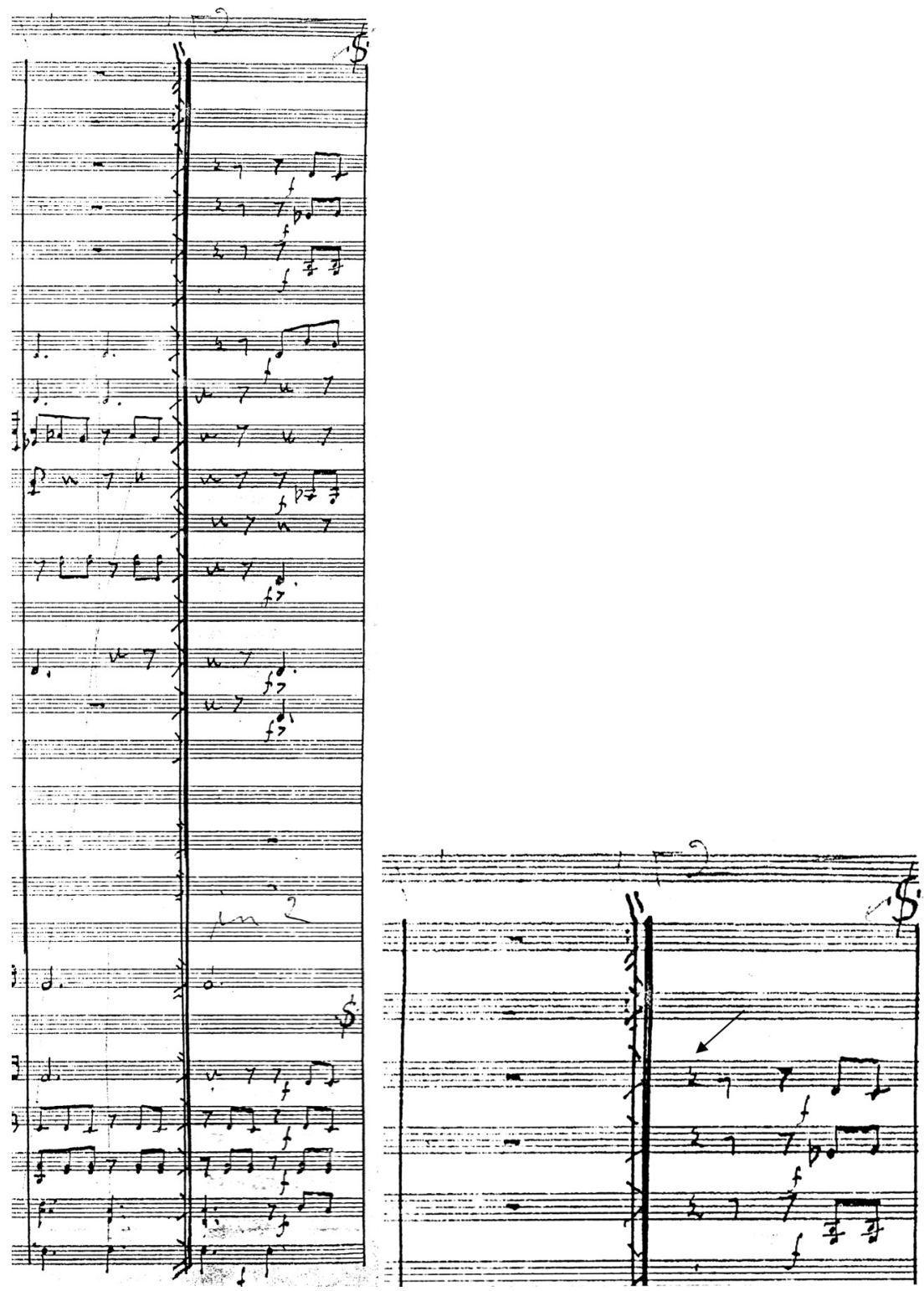

Villa-Lobos. Evocação, compassos 35-6.

Manuscrito e detalhe da grade orquestral, Museu Villa-Lobos, Rio de Janeiro. 


\section{Modinhas e Canções - segundo caderno}

Tabela 6. Modinhas e Canções v.II, data da composição/publicação, gênero e texto

\begin{tabular}{l|l|l|l}
\hline Pobre peregrino & $\begin{array}{l}1943,1964 \\
\text { Editions Max } \\
\text { Eschig }\end{array}$ & canção & $\begin{array}{l}\text { poesias e melodias populares } \\
\text { recolhidas por Epaminondas } \\
\text { Villalba-Filho }\end{array}$ \\
\hline Vida formosa & $\begin{array}{l}1943,1964 \\
\text { Éditions Max } \\
\text { Eschig }\end{array}$ & canção & $\begin{array}{l}\text { poesias e melodias populares } \\
\text { recolhidas por Epaminondas } \\
\text { Villalba-Filho }\end{array}$ \\
\hline Nesta rua & $\begin{array}{l}1943,1964 \\
\text { Éditions Max } \\
\text { Eschig }\end{array}$ & canção & $\begin{array}{l}\text { poesias e melodias populares } \\
\text { recolhidas por Epaminondas } \\
\text { Villalba-Filho }\end{array}$ \\
\hline $\begin{array}{l}\text { Manda tiro, } \\
\text { tiro, lá }\end{array}$ & $\begin{array}{l}1943,1964 \\
\text { Éditions Max } \\
\text { Eschig }\end{array}$ & canção & $\begin{array}{l}\text { poesias e melodias populares } \\
\text { recolhidas por Epaminondas } \\
\text { Villalba-Filho }\end{array}$ \\
\hline João Cambuête & $\begin{array}{l}1943,1964 \\
\text { Éditions Max } \\
\text { Eschig }\end{array}$ & canção & $\begin{array}{l}\text { poesias e melodias populares } \\
\text { recolhidas por Epaminondas } \\
\text { Villalba-Filho }\end{array}$ \\
\hline Na corda da viola & $\begin{array}{l}1943,1964 \\
\text { Éditions Max } \\
\text { Eschig }\end{array}$ & canção & $\begin{array}{l}\text { poesias e melodias populares } \\
\text { recolhidas por Epaminondas } \\
\text { Villalba-Filho }\end{array}$ \\
\hline
\end{tabular}

Todas as canções das Modinhas e Canções v.II foram compostas no Rio de Janeiro. Ao contrário das do primeiro caderno, todas as canções foram compostas/harmonizadas em 1943.

Segundo informação de site do MuseuVilla-Lobos, o nome Epaminondas Villalba-Filho foi usado algumas vezes como pseudônimo do próprio HeitorVilla-Lobos. Tarasti (1995, p.232) lembra que o segundoálbum das Modinhas e Canções contém as mesmas canções do Guia Prático (1932-1949), porém harmonizadas de uma maneira diferente.

\section{Pobre peregrino}

Rio de Janeiro, 1943.

\section{Texto}

O pobre peregrino

Que anda de porta em porta,

Pedindo uma esmola

Pelo amor de Deus. 
Por caridade senhora!

O peregrino é pobre,

Pede uma esmola

Pelo amor de Deus,

O peregrino é pobre,

Pede uma esmola

Pelo amor de Deus.

Ah!

O lamento do peregrino aparece no texto em português e vem refletido nas frases descendentes do canto. Procedimento típico do barroco, sistematizado no estudo da teoria dos afetos. Seu bordão tem uma regularidade monótona, apresentando o texto sempre em frases de dois em dois compassos, fato interrompido somente pelas duas frases de quatro compassos apresentadas pelo piano ou pelo grupo instrumental, em movimento ascendente, que em contraste com as frases descendentes do canto margeiam a canção, na introdução e na coda.

\section{Estrutura formal e harmônica}

A insistente linha do canto, alusão ao lamento do peregrino, contrapõe-se à linha instrumental, que traz variedade à forma musical, indicando uma seção B que se inicia no compasso 15 e termina no compasso 26. Essa seção no manuscrito é repetida com casas de primeira e segunda vez.

As mudanças de andamento também articulam a forma: introdução Quasi allegretto, seção A Lento, seção B Meno (mais lento ainda) e coda Allegretto.

Tonalidades:

Seção A: lá maior.

Seção B: fá \# menor eólio.

No manuscrito da Max Eschig vimos uma anotação a lápis do próprio compositor, prenunciando a instrumentação orquestral da canção. 


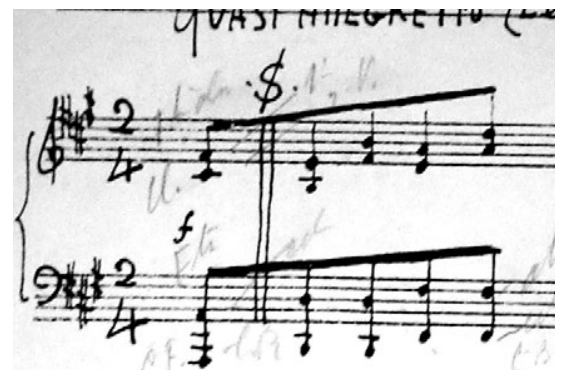

Villa-Lobos. Pobre peregrino, versão canto e piano, compasso 1. Éditions Max Eschig, Paris.

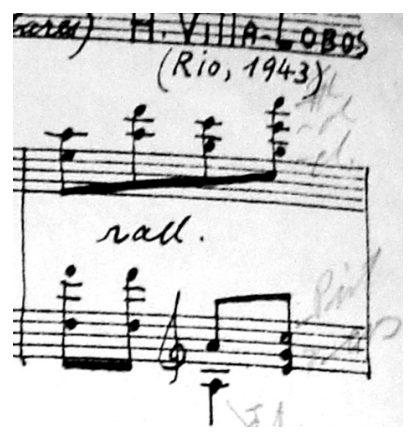

Villa-Lobos. Pobre peregrino, versão canto e piano, compasso 3. Éditions Max Eschig, Paris.

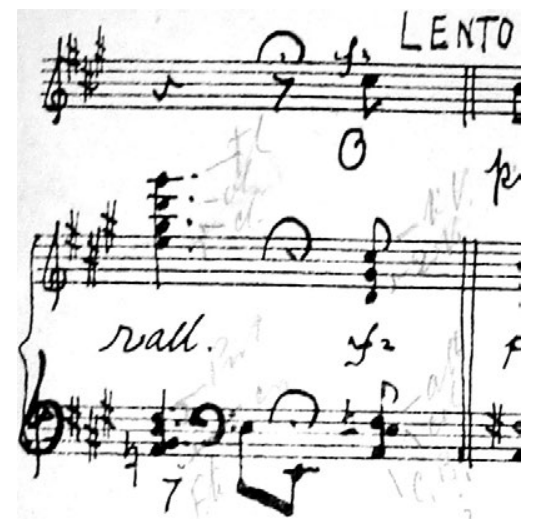

Villa-Lobos. Pobre peregrino, versão canto e piano, compasso 4. Éditions Max Eschig, Paris. 


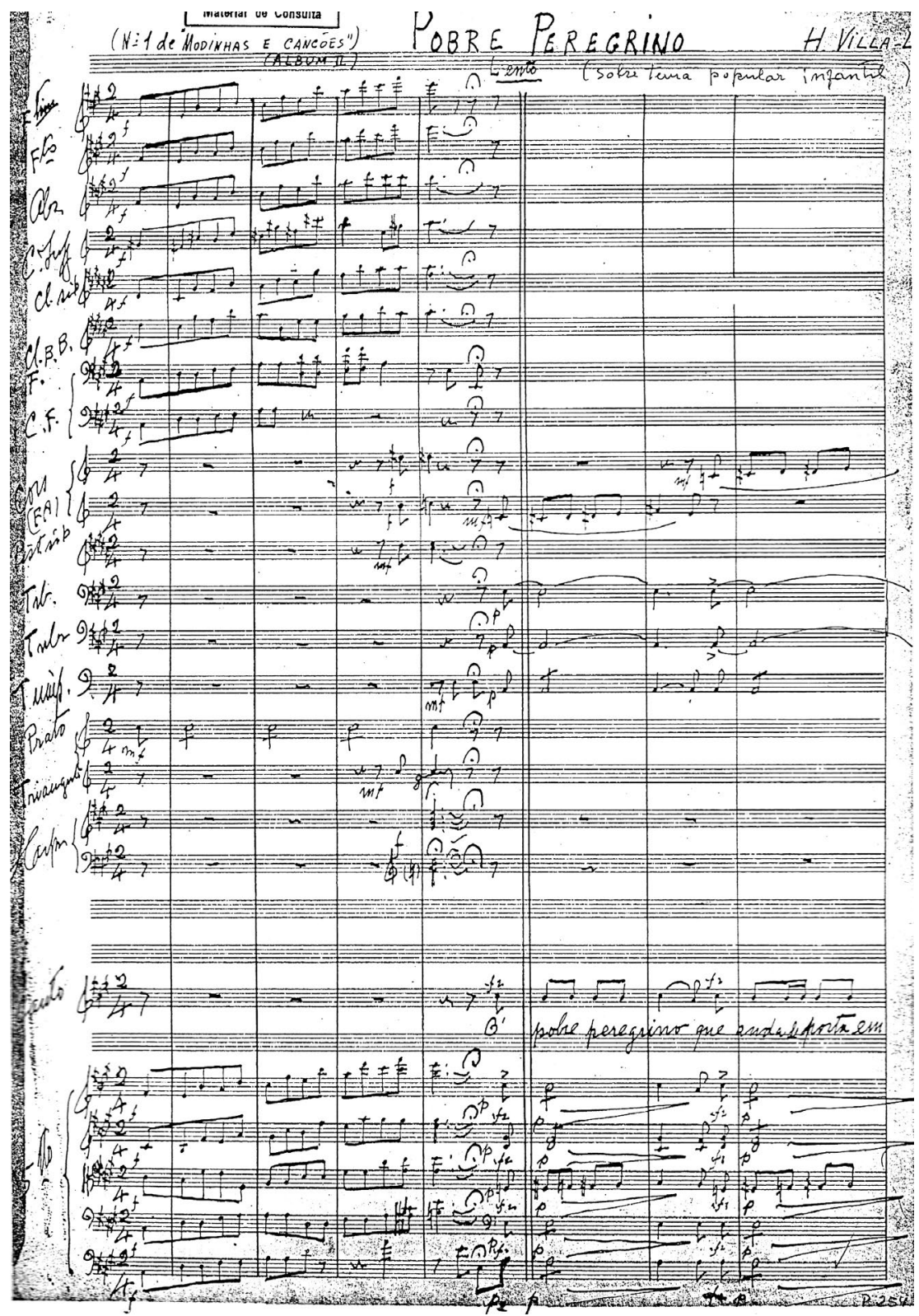

Villa-Lobos. Pobre peregrino, versão orquestral. Museu Villa-Lobos, Rio de Janeiro. 


\section{Aspectos interpretativos}

Abaixo, sugerimos alguns dedilhados e pedais que poderão ser úteis para a interpretação da parte pianística da canção:

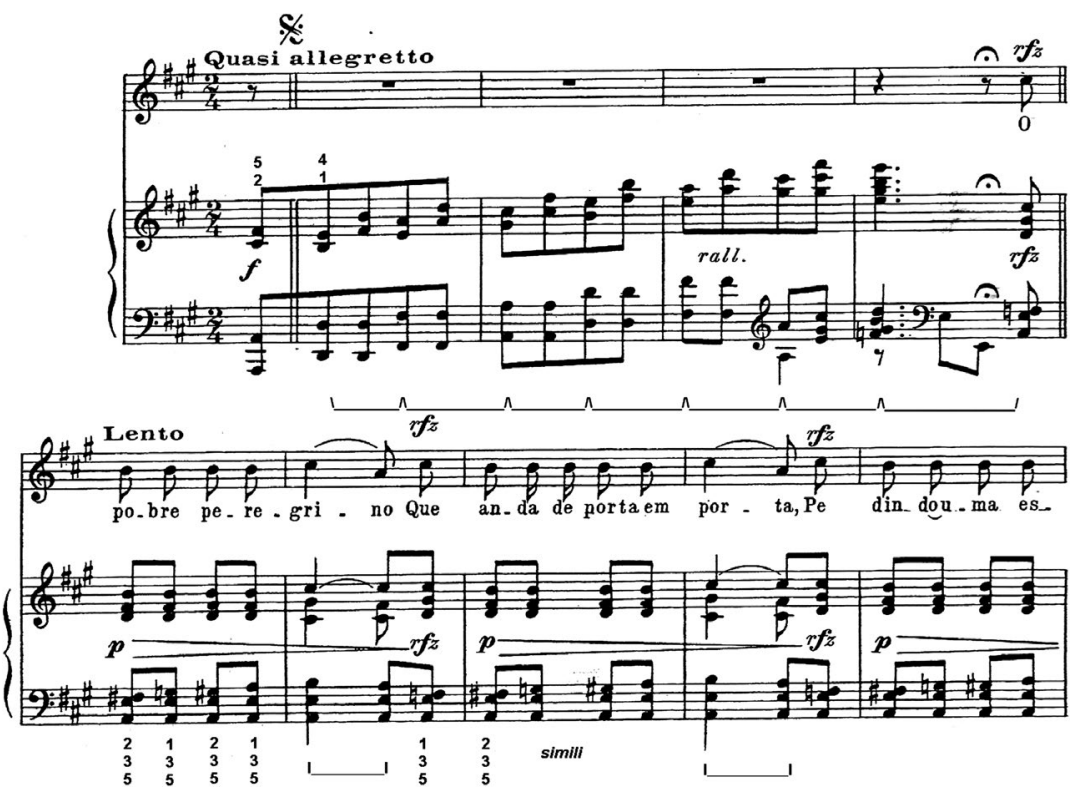

Villa-Lobos. Pobre peregrino, pedal e dedilhados.

Éditions Max Eschig, Paris, 1964. 


\section{Edição e manuscritos}

Há uma omissão de um sinal de repetição pela editora Max Eschig. O sinal aparece no manuscrito para voz e piano da Biblioteca Nacional da França e na versão orquestral da obra, do acervo do Museu Villa-Lobos, do Rio de Janeiro.

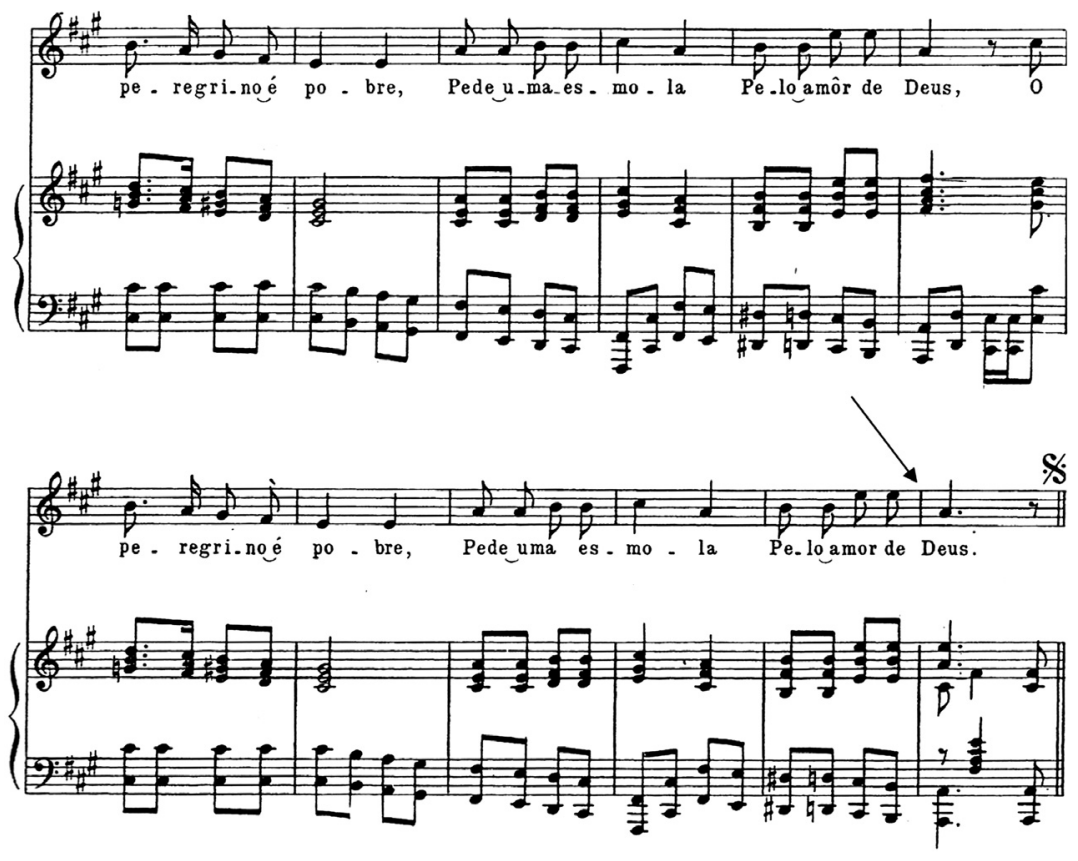

Villa-Lobos. Pobre peregrino.

Éditions Max Eschig, Paris, 1964. 

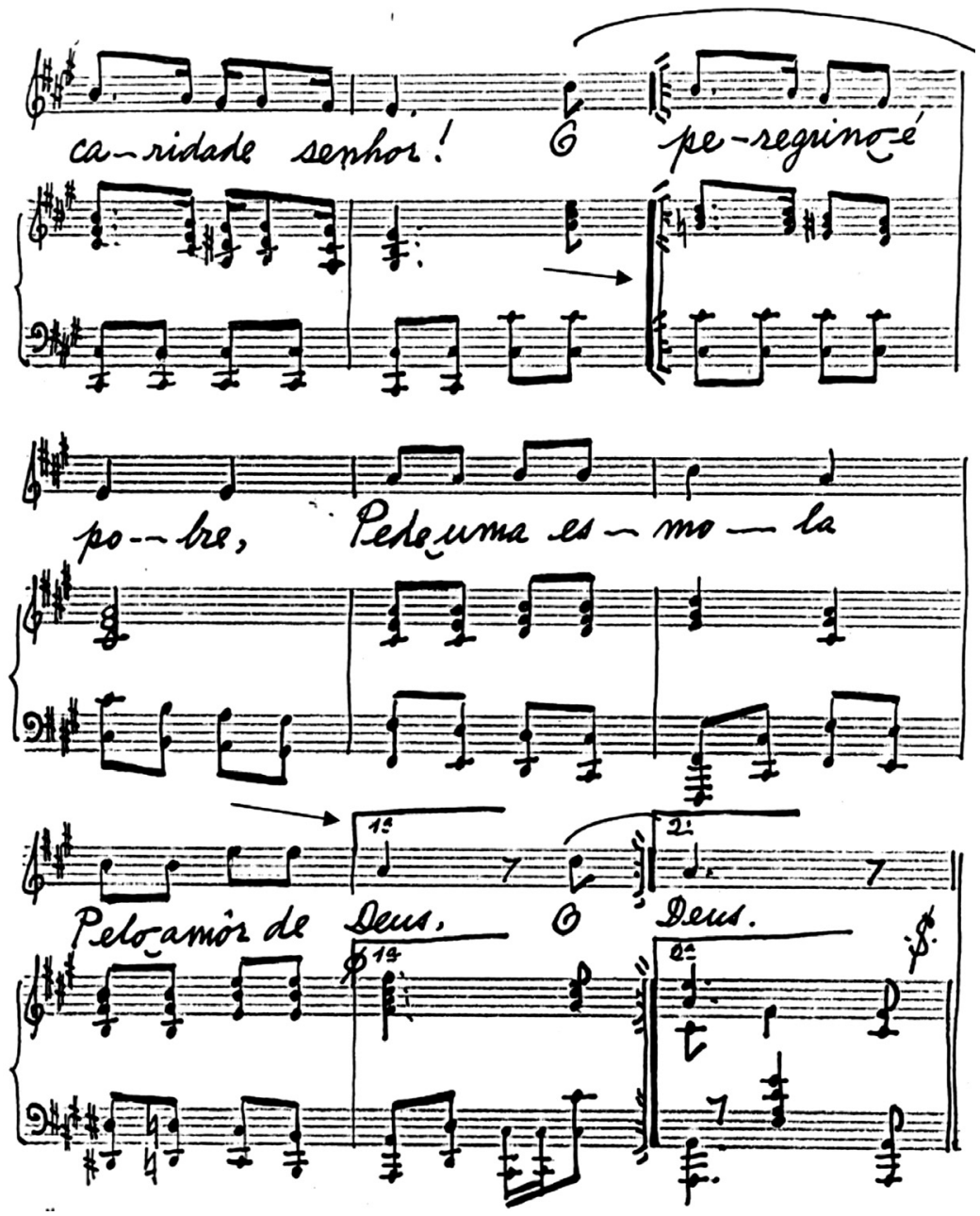

Villa-Lobos. Pobre peregrino, versão para canto e piano. Manuscrito, Biblioteca Nacional da França, Paris. 


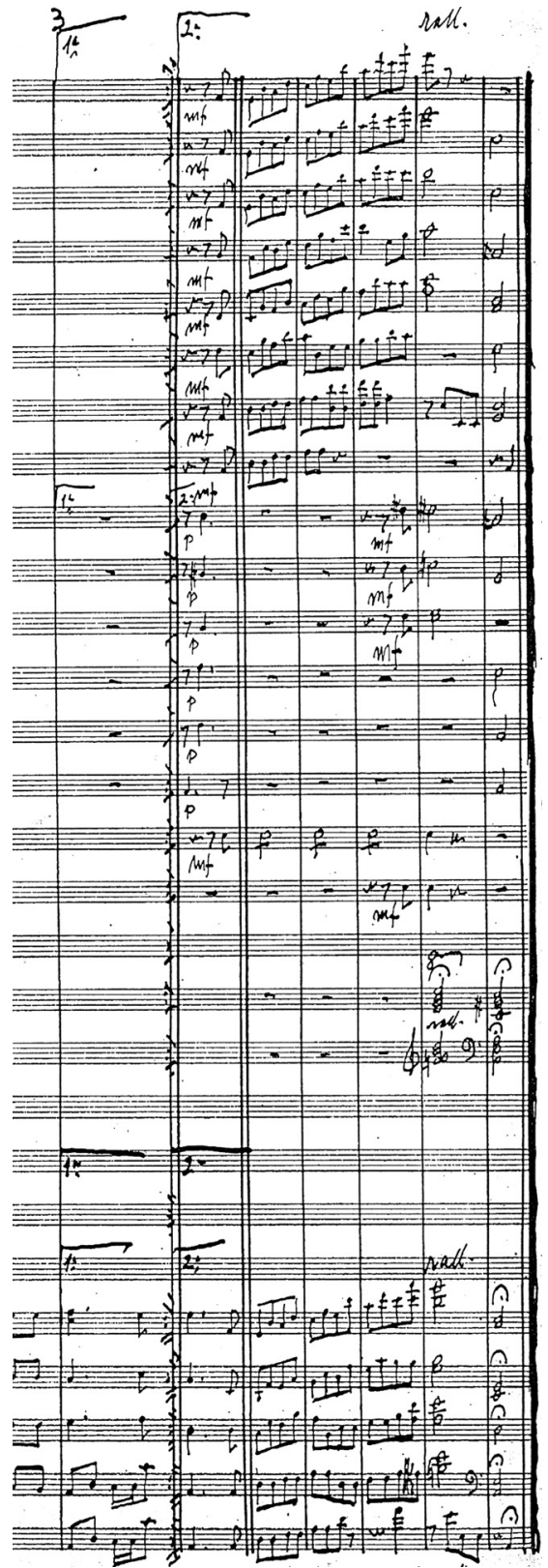

Villa-Lobos. Pobre peregrino, versão para canto e orquestra. Manuscrito, Museu Villa-Lobos, Rio de Janeiro. 
2. Notar a versão da mesma canção no Guia Prático, nำ99. ${ }^{9} \mathrm{O}$ arranjo está transposto dois tons abaixo, aparece abreviado em alguns compassos da introdução e da coda. É destinado à execução de canto com piano ou conjunto instrumental. As indicações de metrônomo Poco animato (semínima 132) e Poco lento confrontam-se com o Quasi allegretto, Lento e o Meno (o que significa Menos que o Lento) assinalados na versão das Modinhas e Canções v.II.
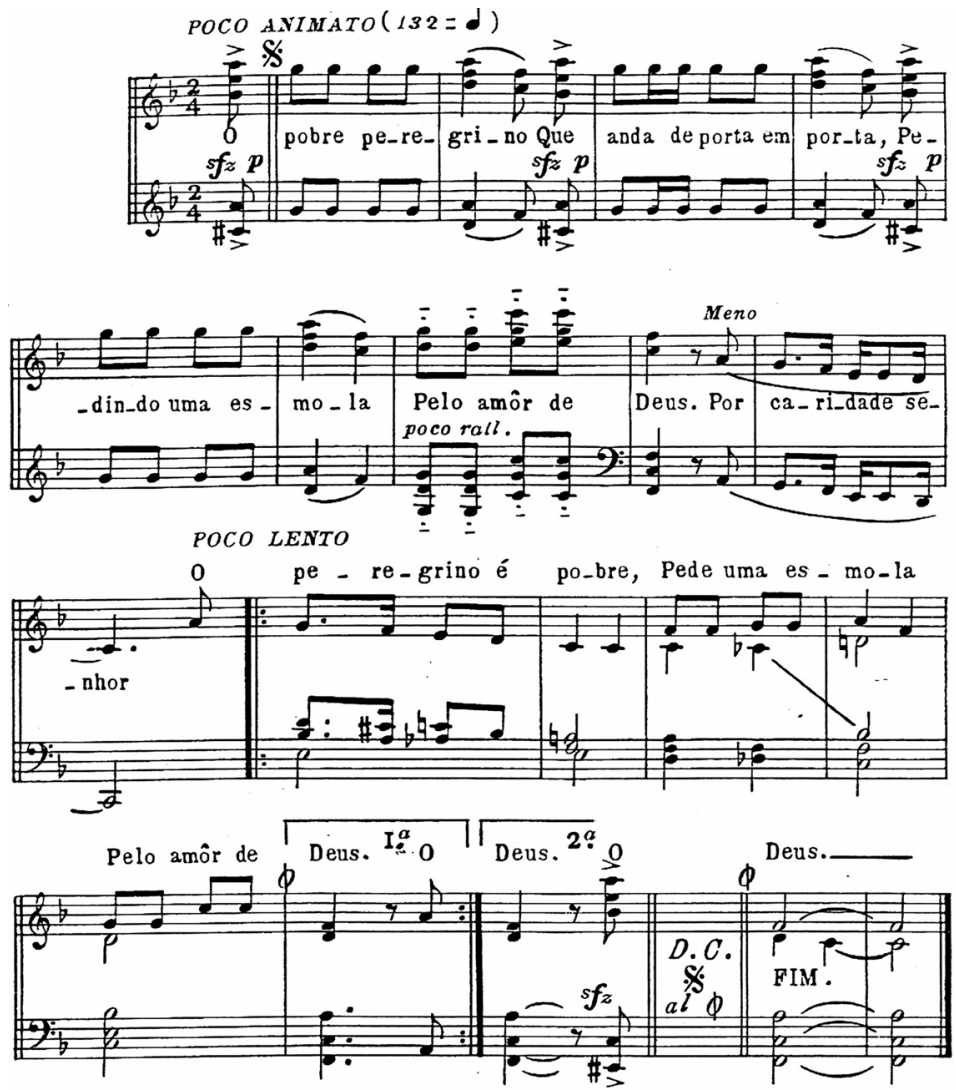

Villa-Lobos. Pobre peregrino. Guia Prático, no99.

Editora Irmãos Vitale, São Paulo.

9 Segundo Elias (1995, p.242), um grande número de canções de origem portuguesa e francesa estão compiladas nos volumes do Guia Prático de Villa-Lobos e são transfiguradas pela ótica sul-americana. 


\section{Vida formosa}

Rio de Janeiro, 1943.

\section{Texto}

O moreno é meu,

Não é de mais ninguém

Quem tiver inveja ora faça assim também,

Menina, minha menina, entre dentro desta roda,

Diga um verso bem bonito, diga adeus e vá se embora.

Ai; Juquinha, Juquinha meu bem, a vida é formosa para quem amores tem

Ai; Juquinha, Juquinha meu bem, a vida é formosa para quem amores tem

Um, dois, três,

Quatro, cinco, seis!

Um, dois, três,

Quatro cinco, seis!

Um, dois, três,

Quatro, cinco, seis!

Sete, oito, nove, para doze faltam três.

Ah! Ah! Ah! Ah! Ah!

A canção é composta sobre um acompanhamento rítmico muito flexível. O compositor explora a constante polirritmia entre o canto e o acompanhamento instrumental, assim como entre as mãos direita e esquerda do pianista.

Não obstante, Villa-Lobos aplica a flexibilidade rítmica a outros parâmetros musicais. Observar que a adequação do texto na canção provoca alguns acentos fora da métrica musical. O cantor deverá saber exatamente onde está a sílaba tônica das palavras para realizar um fraseado coerente, valorizando a flexibilidade rítmica e também a boa compreensão do texto. Exemplos:

No compasso 10: na palavra Me-ni-na, a sílaba tônica destacada aparece em tempo fraco do compasso. Para uma boa compreensão do texto, deve-se aplicar um leve acento tônico, fora do acento métrico 
musical. O compasso do canto ficará metricamente irregular, ou seja, será composto de três colcheias mais cinco colcheias.

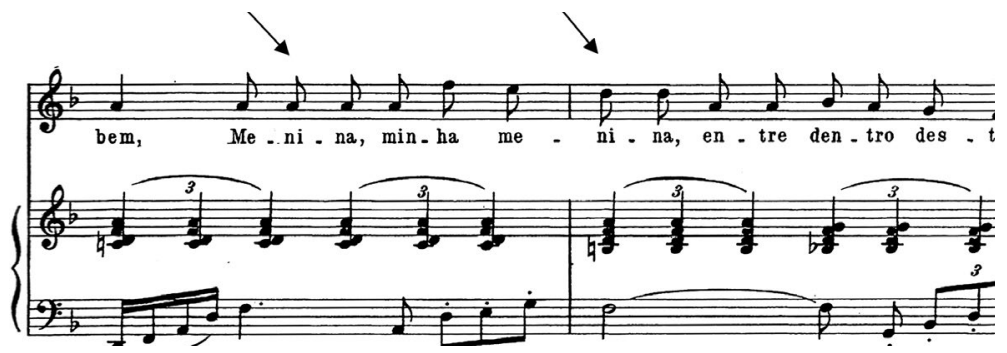

Villa-Lobos. Vida formosa, compassos 10-1.

Éditions Max Eschig, Paris, 1964.

No compasso 14, a palavra "ai" é uma interjeição e não um advérbio de lugar. Portanto a vogal $a$ deve ser acentuada com a voz - mais uma vez fora da métrica musical. Notar o erro gráfico na edição Max Eschig, no compasso 18. Na segunda interjeição, a partitura traz um acento em "ai", transformando a interjeição em advérbio de lugar: "aî". Assim, qualquer cantor não familiarizado com a língua portuguesa cometerá nesse ponto um erro de pronúncia e de sintaxe.

O mesmo fenômeno métrico que ocorreu no compasso 10 ocorrerá neste compasso, ou seja, teremos três colcheias mais cinco colcheias. Procedimento idêntico ocorre no compasso 18:

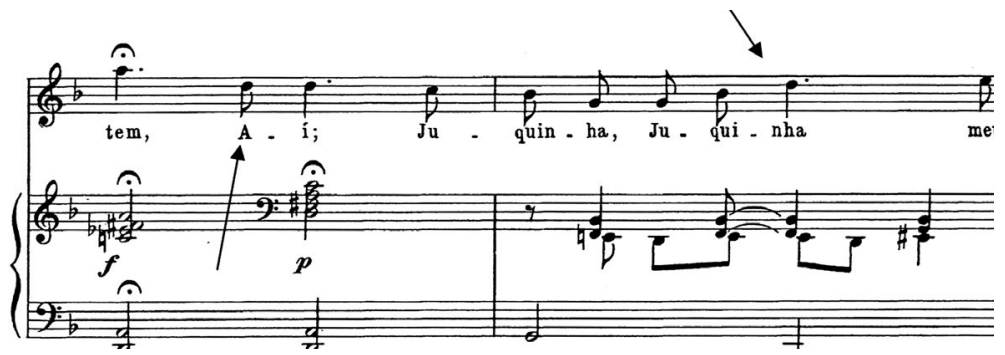

Villa-Lobos. Vida formosa, compassos 18-9.

Éditions Max Eschig, Paris, 1964.

Procedimento semelhante ocorre no compasso 15 na palavra "Ju-qui-nha": três colcheias mais cinco colcheias. Na sua reprise, no 
compasso 19, ocorre a mesma relação música/acentuação métrica do texto. "Ju-qui-nha": três colcheias mais cinco colcheias.

No compasso 27 há um erro de grafia. A palavra é "quatro" e não "ouatro".

\section{Estrutura formal e harmônica}

Tonalidade: ré menor.

Introdução piano: Poco allegro: compassos 1 a 5, ré menor.

Seção A: Marcha lenta: compassos 6 a 21, ré menor. No 14 há um desvio para a região da subdominante (sol menor). Nos compassos 20 e 21 temos a volta da tonalidade de ré menor.

Seção B: compassos 22 a 29. Muda a textura musical do canto e do acompanhamento, ré menor.

Coda: Più mosso: compassos 30 a 39, ré menor. Desenvolvimento instrumental dos motivos apresentados pelo piano com acompanhamento da voz.

\section{Aspectos interpretativos}

As sugestões seguintes de dedilhado e pedal poderão ser aplicadas a vários momentos musicais da canção:
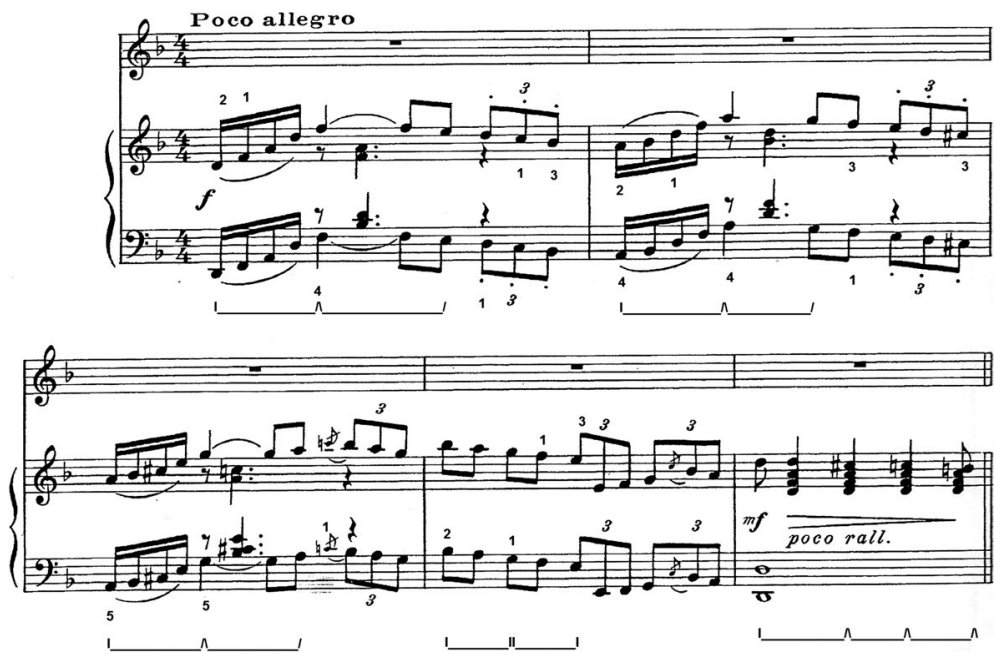

Villa-Lobos. Vida formosa, dedilhados e pedais, compassos 1-5.

Éditions Max Eschig, Paris, 1964. 


\section{Edição e manuscritos}

1. Falta na edição Max Eschig a ligadura presente no manuscrito.

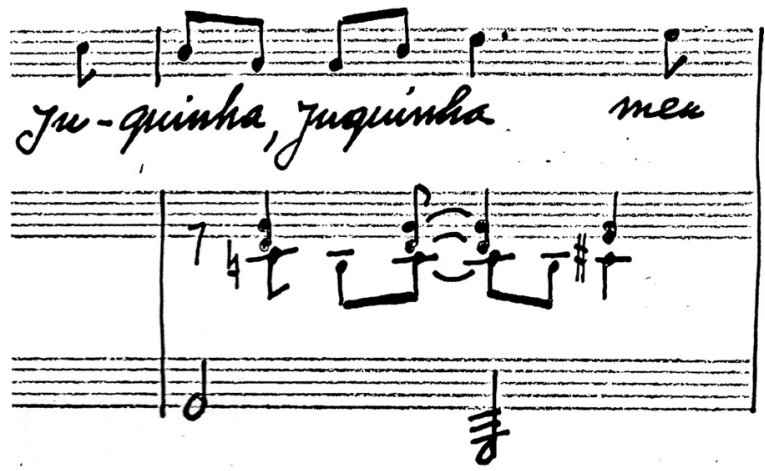

Villa-Lobos. Vida formosa, compasso 19.

Manuscrito, Biblioteca Nacional da França, Paris.
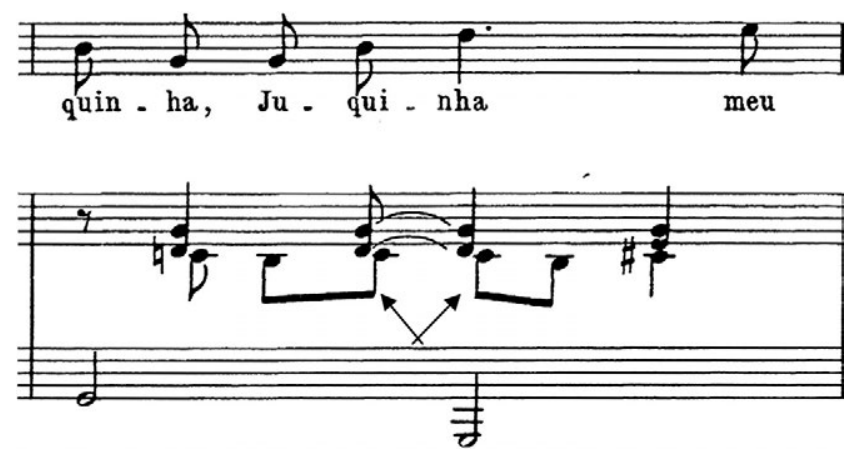

Villa-Lobos. Vida formosa, compasso 19.

Éditions Max Eschig, Paris, 1964.

2. A melodia foi rearranjada para a Coleção do Guia Prático, no132. Nesse arranjo, o acompanhamento instrumental é diferente e algumas poucas modificações foram feitas na melodia, porém podemos confirmar, também pelo manuscrito da Biblioteca Nacional da França, que nesse caso a nota assinalada é dó \# e não ré, como aparece publicada na edição Max Eschig. 

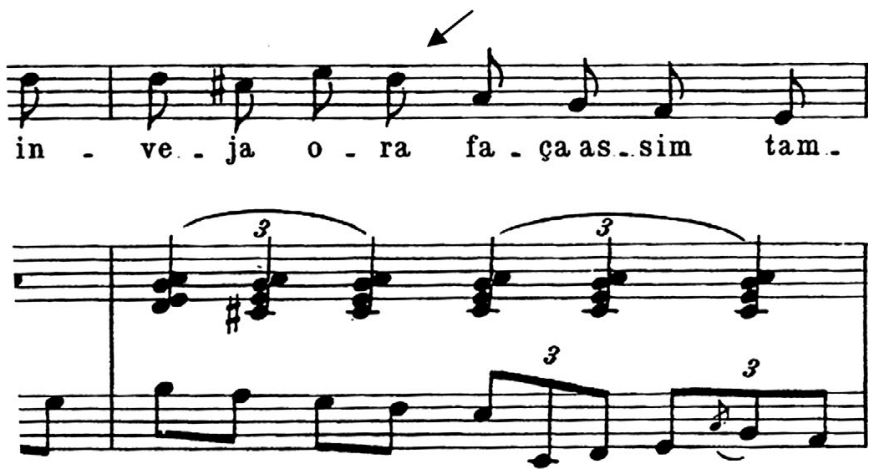

Villa-Lobos. Vida formosa, compasso 9.

Éditions Max Eschig, Paris, 1964.

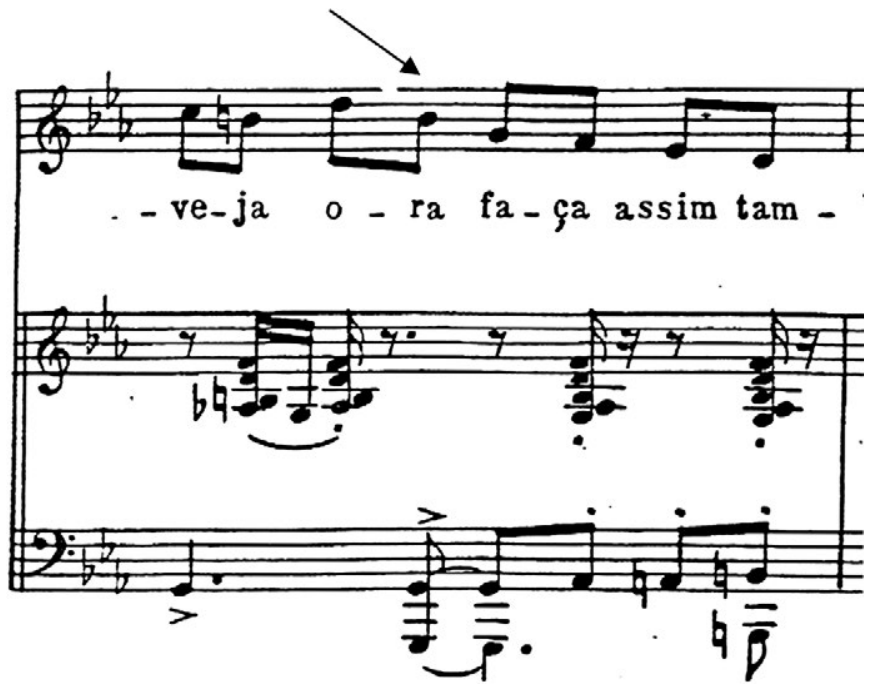

Villa-Lobos. Vida formosa, compasso 9.

Guia Prático para coro a uma voz ou canto e piano ou conjunto instrumental, v.1, n132, Editora Irmãos Vitale, 1953. 


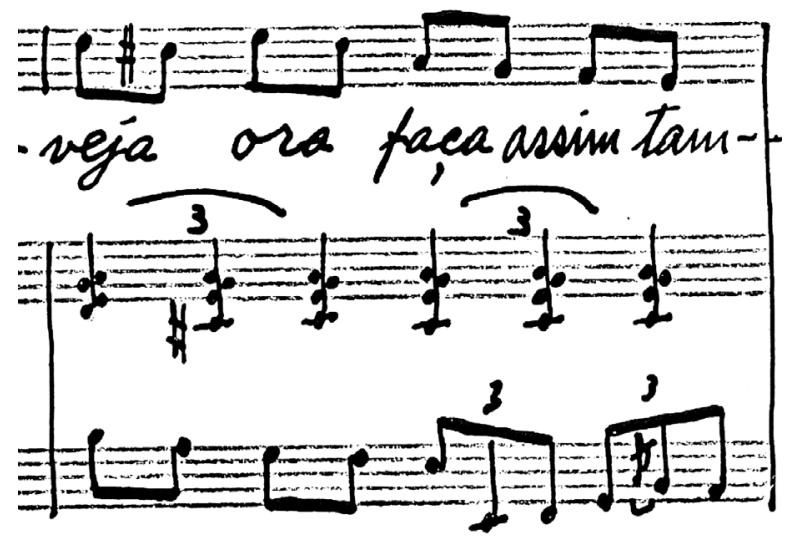

Villa-Lobos. Vida formosa, compasso 19.

Manuscrito para voz e piano, Biblioteca Nacional da França, Paris.

\section{Nesta Rua}

Rio de Janeiro, 1943.

\section{Texto}

Nesta rua, nesta rua tem um bosque

Que se chama, que se chama solidão, Dentro dele, dentro dele mora um anjo, Que roubou, que roubou meu coração, Dentro dele, dentro dele mora um aujo, anjo Que roubou, que roubou meu coração

Si eu roubei, si eu roubei teu coração

Tu também, tu também roubaste o meu;

Si eu roubei si eu roubei teu coração, É porque, é porque te quero bem!

Si eu roubei, si eu roubei teu coração É porque, é porque te quero bem.

Ah! Ah! Ah! 


\section{Estrutura formal e harmônica}

Introdução do piano: Poco moderato: compassos 1 a 3 .

Seção A: Moderato: compassos 4 a 16.

Seção A reprise: compassos 17 a 28.

Coda: mesmo material da introdução, porém dessa vez executado pelo piano e pela voz: compassos 29 a 33 .

Tonalidade: ré menor.

\section{Aspectos interpretativos}

As seguintes sugestões de pedal e dedilhado serão úteis para a execução da canção.
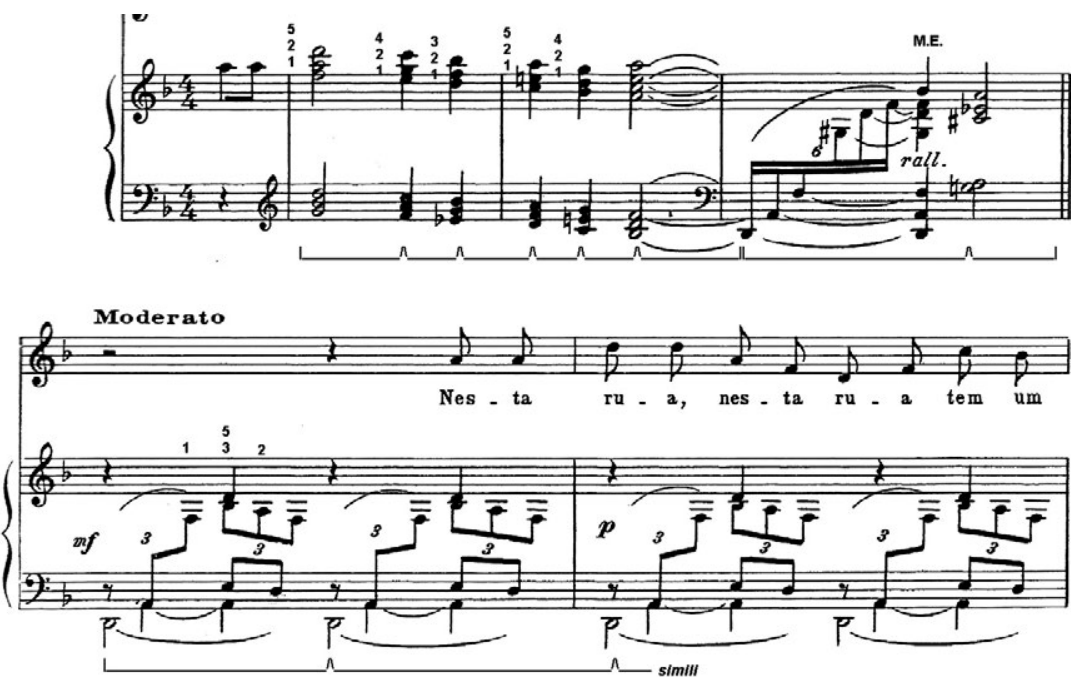

Villa-Lobos. Nesta rua, dedilhados e pedal, compassos 1-5.

Éditions Max Eschig, Paris, 1964. 


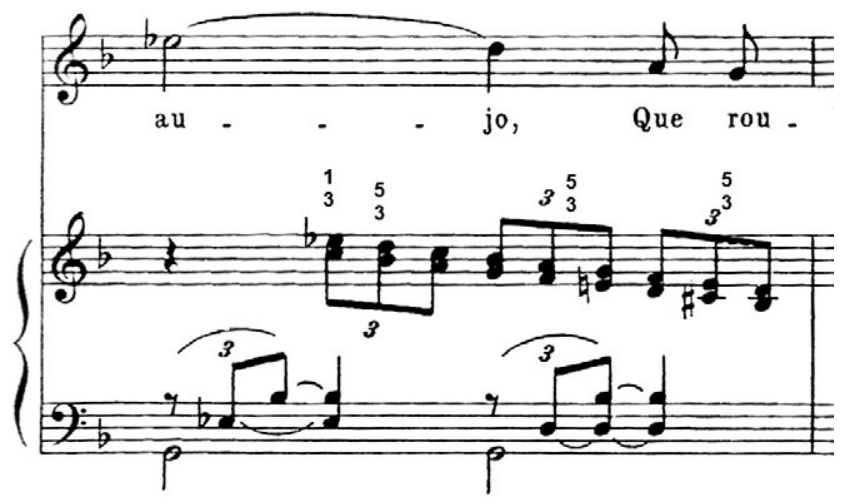

Villa-Lobos. Nesta rua, dedilhado, compasso 14. Éditions Max Eschig, Paris, 1964.
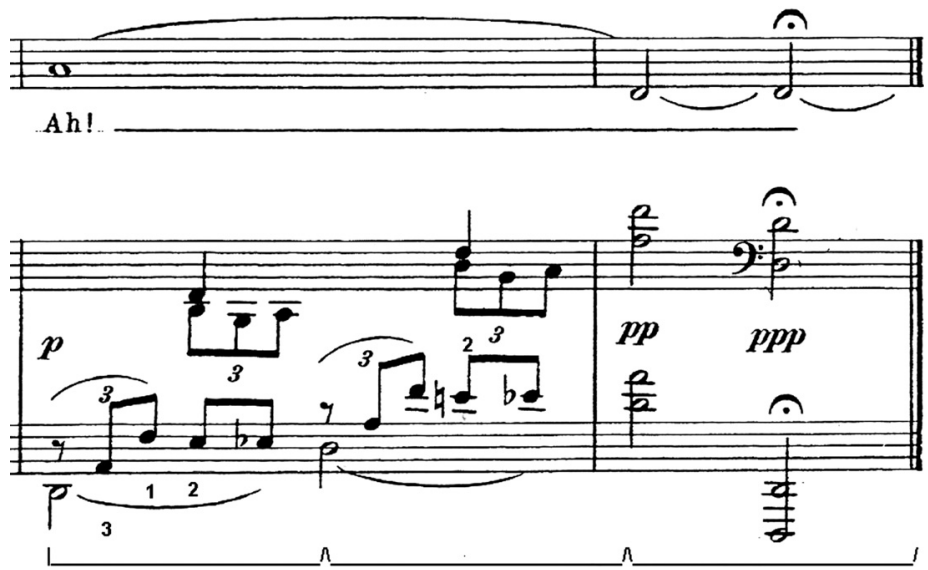

Villa-Lobos. Nesta rua, dedilhado e pedal, compassos 32-3. Éditions Max Eschig, Paris, 1964. 


\section{Edição e manuscritos}

1. Na mão direita do pianista há um intervalo lá - ré. Na edição Max Eschig há uma pausa que interrompe o movimento do compasso anterior.

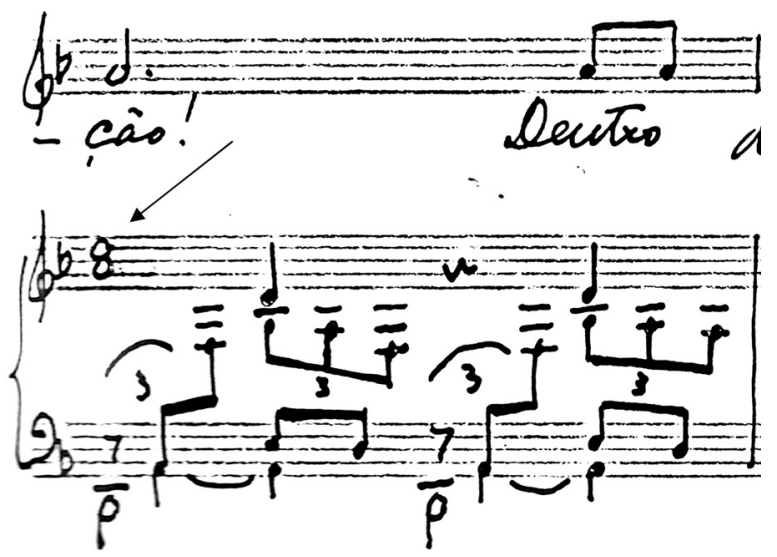

Villa-Lobos. Nesta rua, compasso 12.

Manuscrito, Biblioteca Nacional da França, Paris.

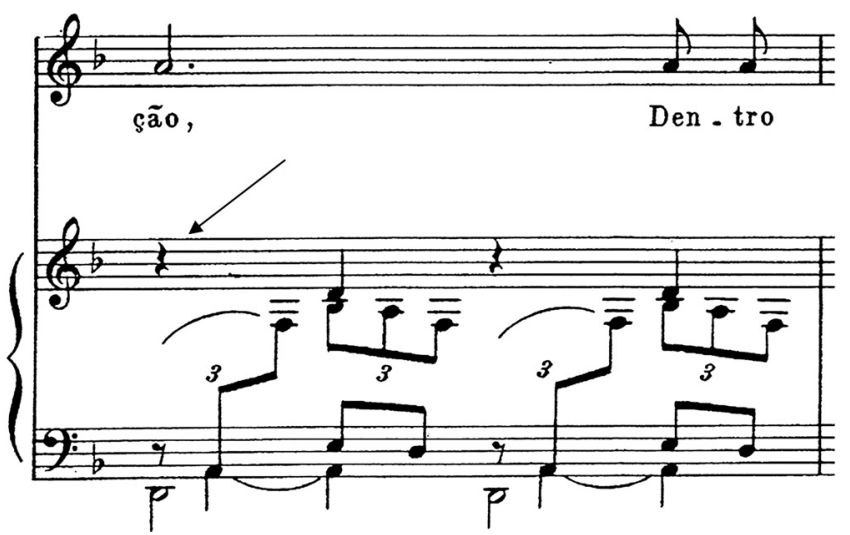

Villa-Lobos. Nesta rua, compasso 12. Éditions Max Eschig, Paris, 1964. 
2. A sequência correta é dó-mi bemol/si bemol-ré/lá-dó. Na edição Max Eschig aparece impresso dó-mi bemol/sol-si bemol/fá-lá.

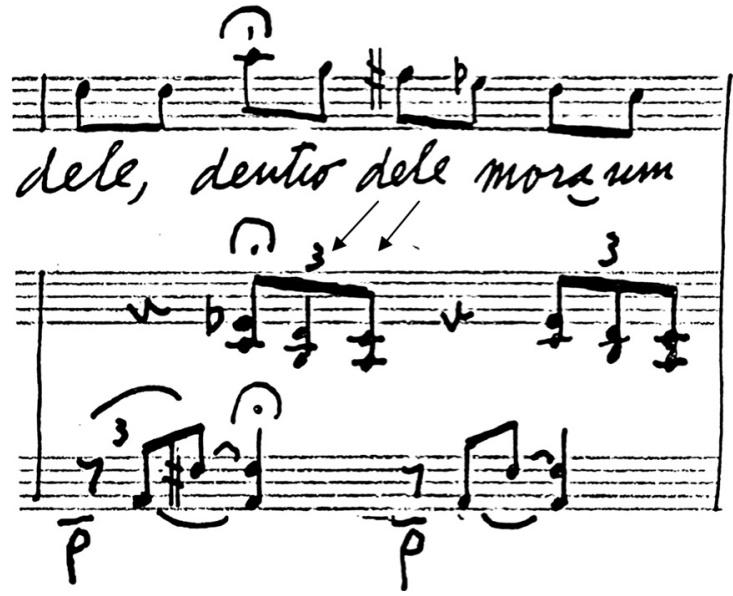

Villa-Lobos. Nesta rua, compasso 13.

Manuscrito, Biblioteca Nacional da França, Paris.
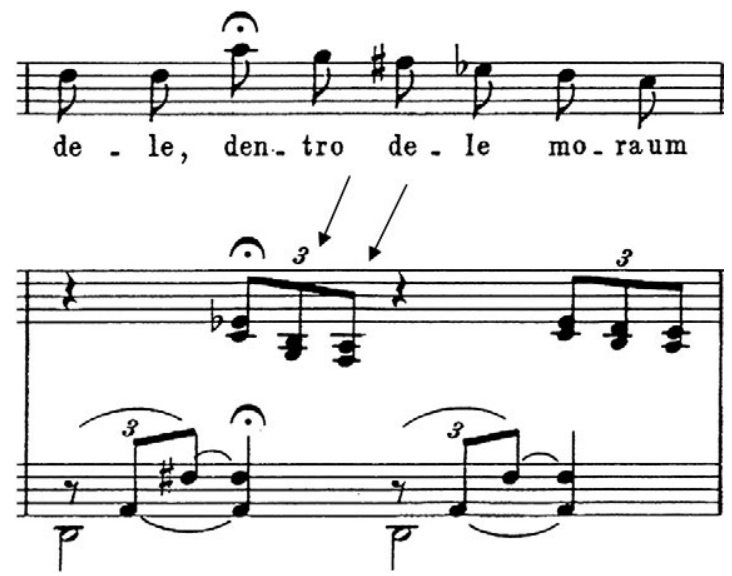

Villa-Lobos. Nesta rua, compasso 13. Éditions Max Eschig, Paris, 1964. 
3. No manuscrito temos o baixo ré, que não aparece na edição Max Eschig.
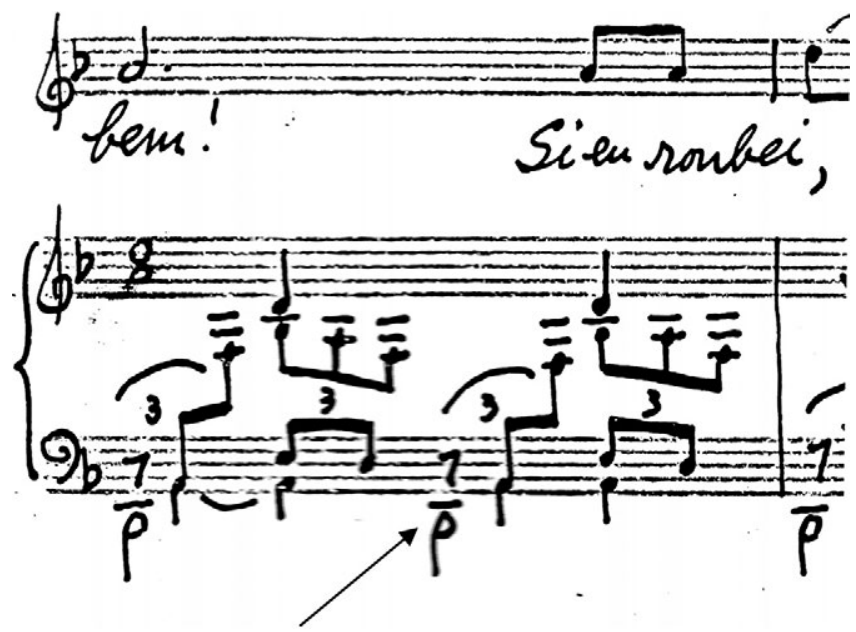

Villa-Lobos. Nesta rua, compasso 24.

Manuscrito, Biblioteca Nacional da França, Paris.

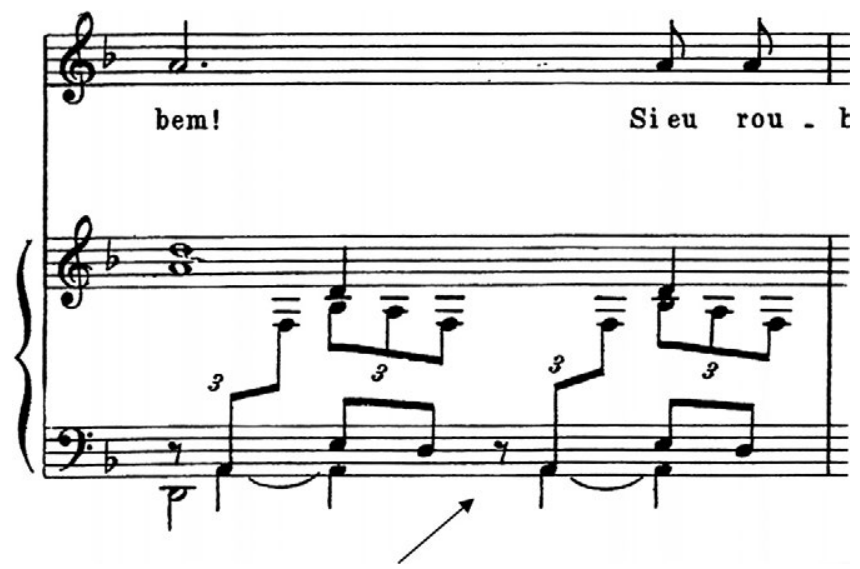

Villa-Lobos. Nesta rua, compasso 24. Éditions Max Eschig, Paris, 1964. 
4. A nota do soprano do acorde do piano é lá natural e não lá bemol, como aparece na edição Max Eschig.
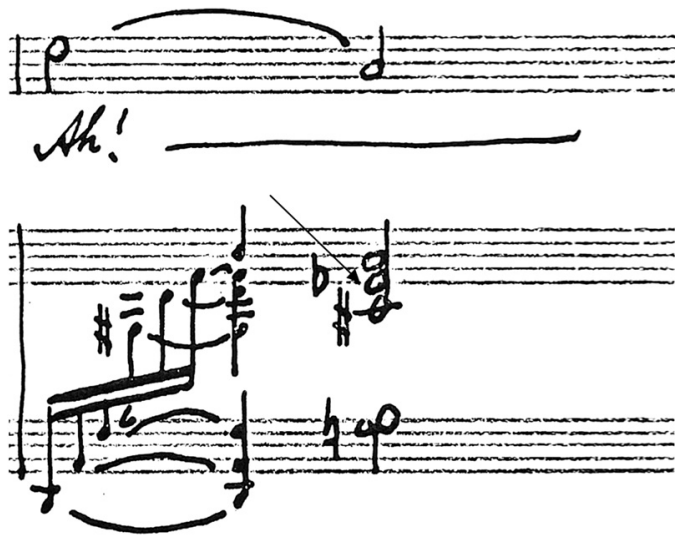

Villa-Lobos. Nesta rua, compasso 31.

Manuscrito, Biblioteca Nacional da França, Paris.

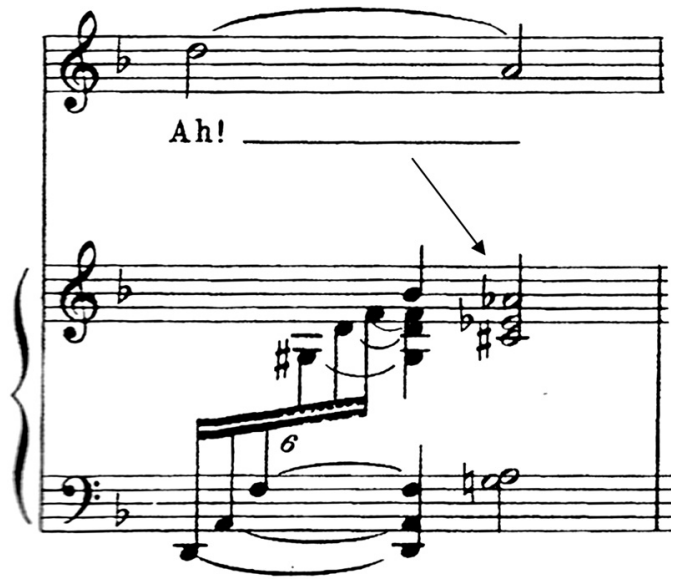

Villa-Lobos. Nesta rua, compasso 31.

Éditions Max Eschig, Paris, 1964. 
IV. Manda tiro, tiro, lá

Rio de Janeiro, 1943.

\section{Texto}

Bom dia vossa senhoria

Mando tiro, tiro, lá,

Bom dia vossa senhoria

Mando tiro, tiro, lá! lá!

La, la, la, la, la, la la... etc.

\section{Estrutura formal e harmônica}

Introdução do piano solo: compassos 1 a 8 .

Seção A: duas frases de oito compassos cada uma: compassos 9 a 24 .

Reprise da seção A: compassos 25 a 40.

Coda com material temático da introdução com voz e piano.

Tonalidade: sol maior.

No manuscrito da Biblioteca Nacional da França, vemos a indicação da instrumentação da canção, em anotação a lápis do próprio compositor.

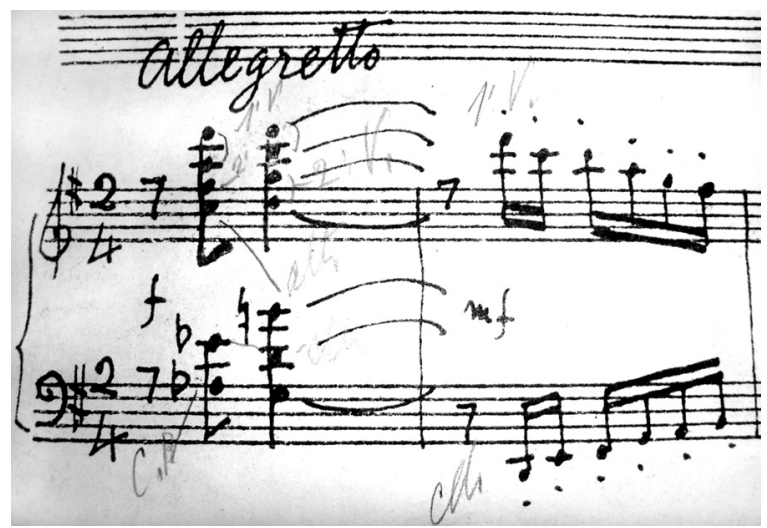

Villa-Lobos. Manda tiro, tiro, lá, compassos iniciais.

Manuscrito, Biblioteca Nacional da França, Paris. 


\section{Aspectos interpretativos}

Abaixo, sugestões para aplicação do pedal e dedilhado na execução do pianista.

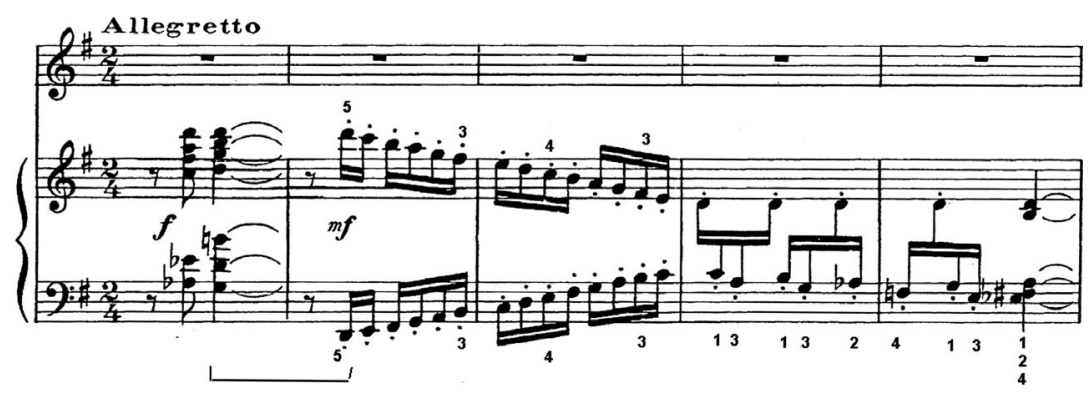

Villa-Lobos. Manda tiro, tiro, lá, dedilhados e pedal, compassos 1-5.

Éditions Max Eschig, Paris, 1964.

\section{Edição e manuscritos}

1. Falta acento na primeira nota da appoggiatura.

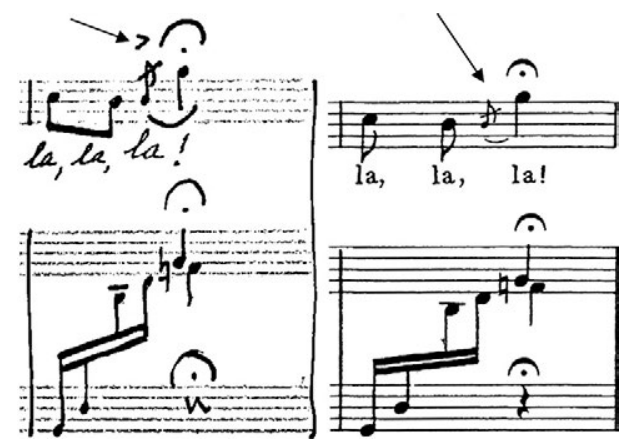

Villa-Lobos. Manda tiro, tiro, lá, compassos 20 e 36.

Manuscrito, Éditions Max Eschig e Biblioteca Nacional da França, Paris.

Notar o mesmo acento na versão da mesma canção no Guia Prático, nำ73. O arranjo está transposto um tom abaixo; aparece abreviado em alguns compassos da introdução e da coda. Destinado à execução de canto com piano, piano solo ou com conjunto instrumental. 
Notar a indicação de metrônomo Vivace para a introdução (semínima 138) e Allegretto non troppo para a canção.

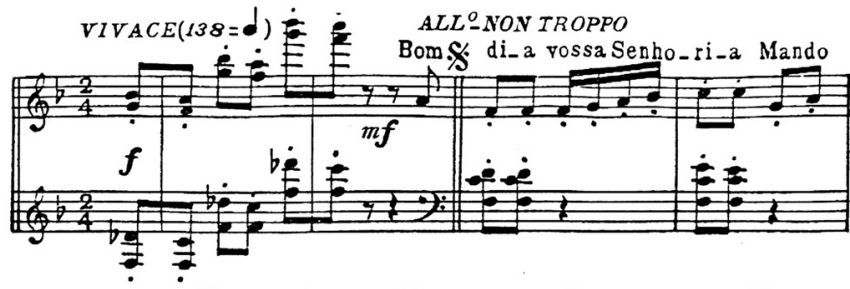
ti - ro, ti - ro, lál
Bom di -a vossa Senho - ri-a Mando

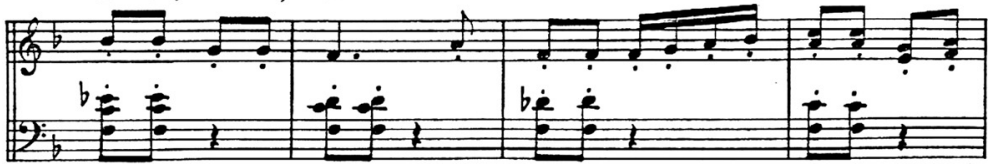

lá!
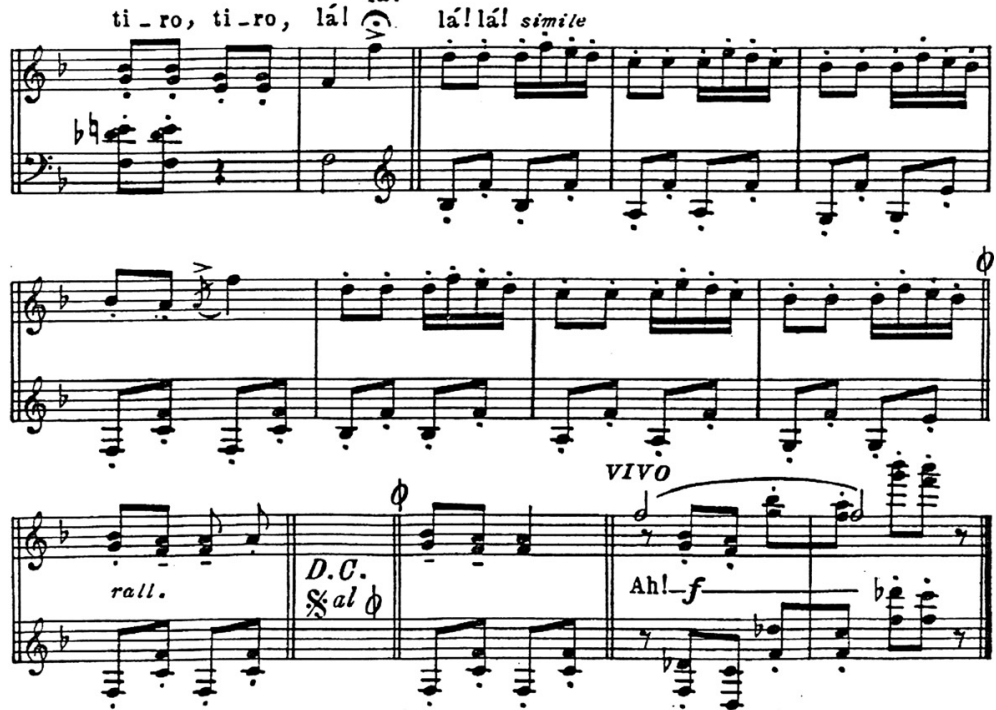

Villa-Lobos. Manda tiro, tiro, lá, Guia Prático, nำ73.

Editora Irmãos Vitale, Brasil. 


\section{João Cambuête}

\section{Texto}

João, dão João!

João, dão João!

João Cambuête, meu filho,

Toma lá tua pêta, meu filho

Êh! dão João!

João, dão João!

João Cambuête, meu filho,

Toma lá tua pêta, meu filho

Êh! dão João!

João, dão João!

João, dão João!

João, dão João!

Eh!

O texto é uma "canção das negras", como vem no título do manuscrito, informação que não consta da edição da Max Eschig. Em linguagem popular, "peta” significa chupeta.

\section{Estrutura formal e harmônica}

Canção com estrutura simples, que alterna a frase de quatro compassos, apresentada pelo piano na introdução, com uma frase de três compassos ritmicamente mais movida, em quiálteras, apresentada pelo canto.

Tonalidade: lá maior.

\section{Aspectos interpretativos}

Aconselha-se sustentar o acorde seguinte com o pedal tonal, durante toda a canção. Assim, o pianista será capaz de realizar os diferentes toques pianísticos exigidos pela partitura. 


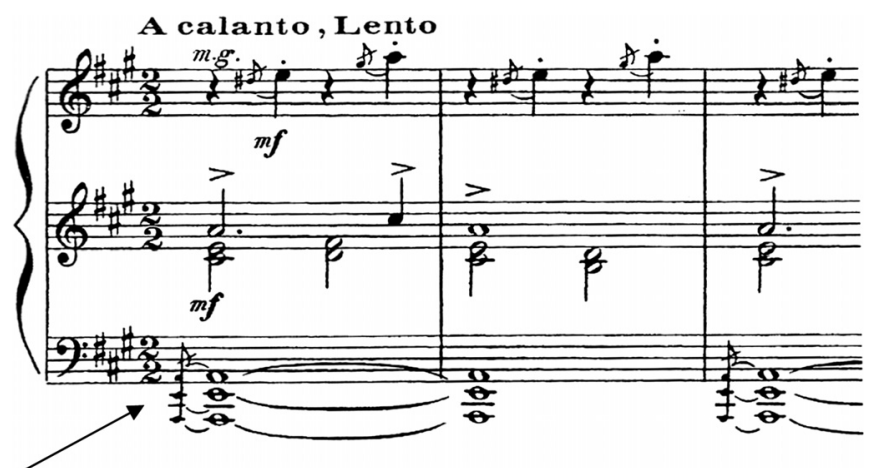

Villa-Lobos. João Cambuête, introdução do piano. Éditions Max Eschig, Paris, 1964.

Edição e manuscritos

$$
\begin{aligned}
& \text { JOÃO CAMBUÊETE } \\
& \text { (JEAN CAMBUÊTE) }
\end{aligned}
$$
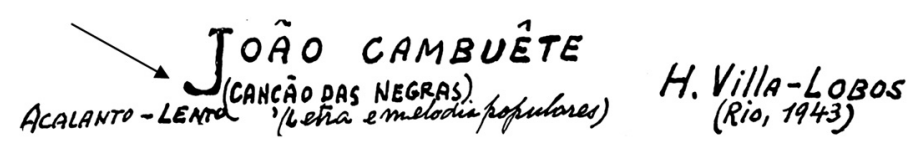

Villa-Lobos. João Cambuête, título.

Éditions Max Eschig e manuscrito da Biblioteca Nacional da França, Paris, 1964.

Há uma versão da mesma canção no Guia Prático, nº66. O arranjo está transposto um tom abaixo, aparece abreviado em alguns compassos e com fórmula de compasso de 2/4. Destinado à execução em piano solo ou com conjunto instrumental. Notar que a indicação de metrônomo (M.M. semínima = 54) não aparece na edição da Max Eschig para voz e piano. 

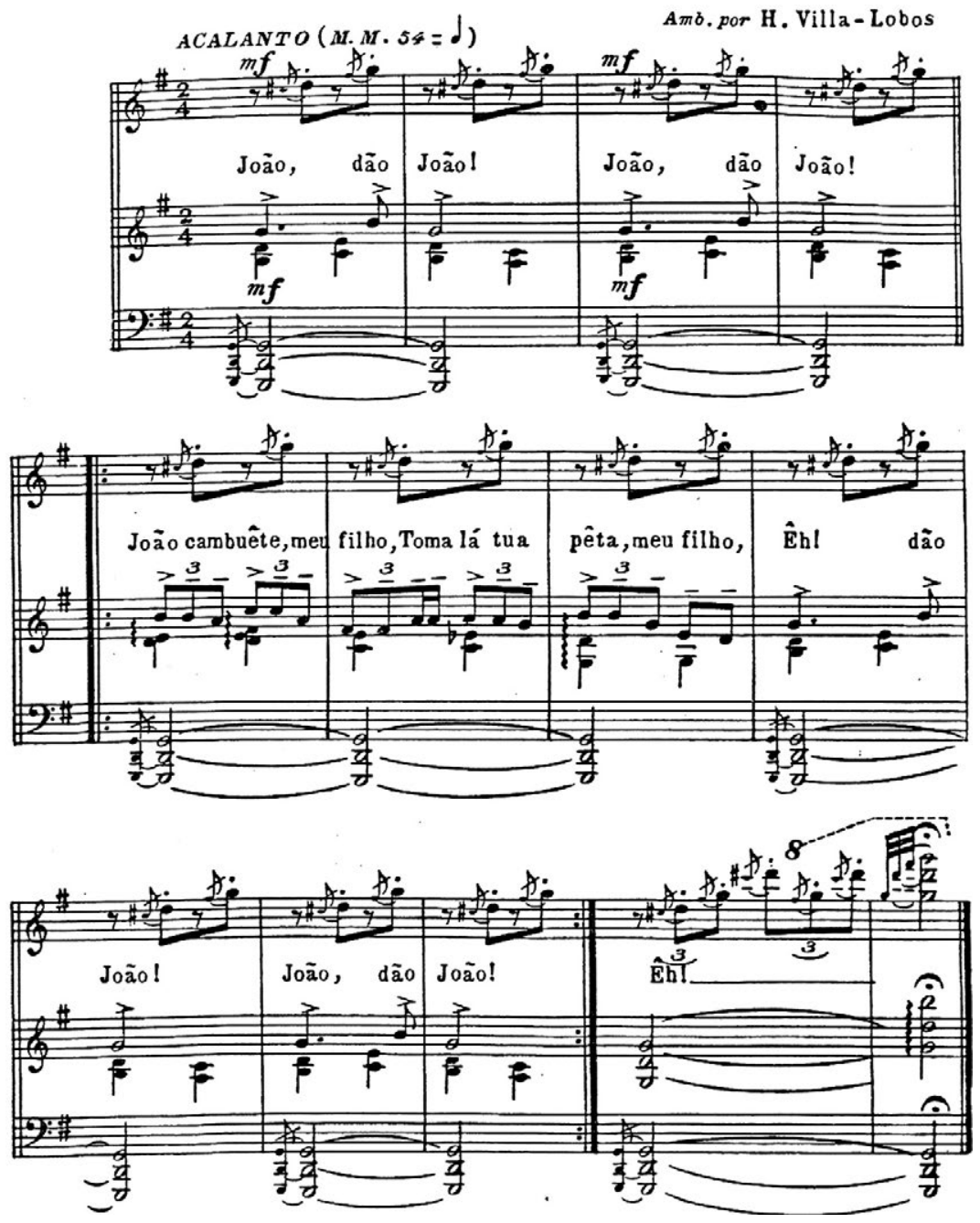

Villa-Lobos. João Cambuête, Guia Prático, no66,

Editora Irmãos Vitale, São Paulo. 


\section{Na corda da viola}

Rio de Janeiro, 1943.

\section{Texto}

$\mathrm{Na}$ corda da viola

Todo mundo bate;

$\mathrm{Na}$ corda da viola

Todo mundo bate;

$\mathrm{Na}$ corda da viola

Todo mundo bate;

$\mathrm{Na}$ corda da viola

Todo mundo bate;

As costureiras

Fazem assim...

Os carpinteiros

Fazem assim...

Os marcineiros

Fazem assim...

(Bis)

La! la! la! la! la! la! Etc.

(Bis)

\section{Estrutura formal e harmônica}

Tarasti (1995, p.232) informa-nos que a canção Na corda da viola foi utilizada no musical Magdalena (1948). A canção tem armadura de clave da escala de lá maior, mas a ênfase sobre a nota mi confere-lhe um caráter modal, configurando auditivamente o modo mixolídio.

Introdução do piano: Allegro: compassos 1 a 6.

Seção A: compassos 7 a 21.

Seção A': compassos 21 a 26, piano solo, tema transposto para ré mixolídio.

Seção A: compassos 27 a 40, reprise de A (compassos 7 a 21). 
Seção B: Più mosso, compassos 41 a 64. O tema principal aparece ritmicamente aumentado na parte solista.

Seção A: compassos 65 a 79, reprise de A (compassos 7 a 21).

Coda: compassos 79 a 82, piano e canto.

\section{Edição e manuscritos}

1. A última colcheia da mão direita é mi e não ré.

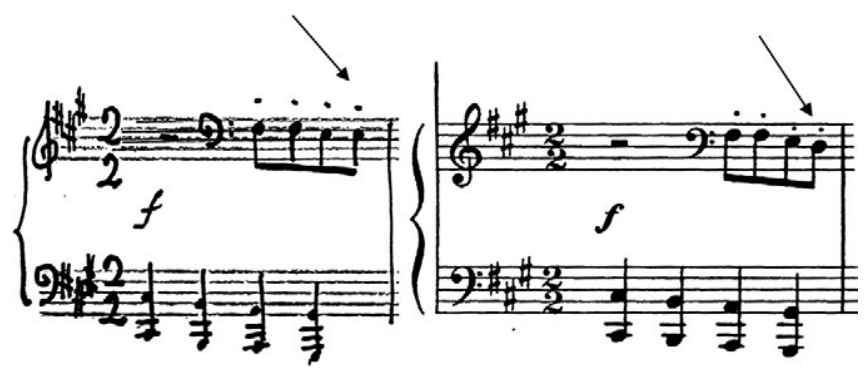

Villa-Lobos. Na corda da viola, introdução, compasso 1. Manuscrito, Biblioteca Nacional da França, Paris.

Éditions Max Eschig, Paris, 1964.

2. A nota correta é lá natural e não lá sustenido, como está grafado na edição da Max Eschig.
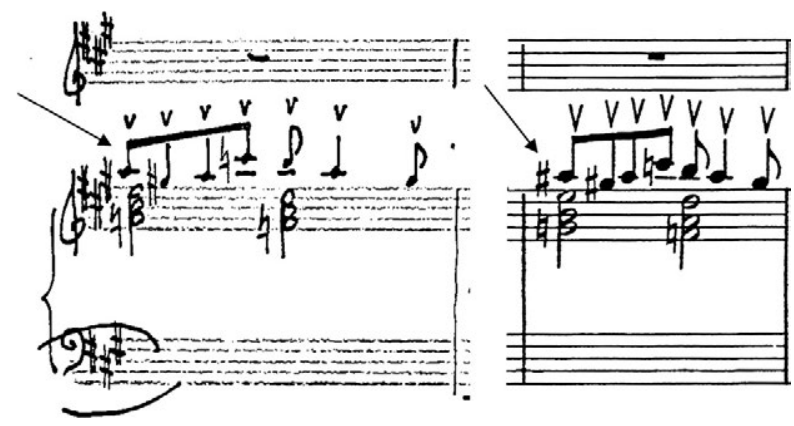

Villa-Lobos. Na corda da viola, introdução, compasso 26. Manuscrito, Biblioteca Nacional da França, Paris. Éditions Max Eschig, Paris, 1964. 


\section{Duas Serestas}

Tabela 7. Duas Serestas, data da composição/publicação, gênero e texto

\begin{tabular}{l|l|l|l}
\hline Serenata & $\begin{array}{l}\text { 1943,1957 } \\
\text { Éditions Max } \\
\text { Eschig }\end{array}$ & canção & poesia David Nasser \\
\hline Voo & $\begin{array}{l}1943,1957 \\
\text { Éditions Max } \\
\text { Eschig }\end{array}$ & canção & poesia Abgar Renault \\
\hline
\end{tabular}

As Duas Serestas, números 13 e 14, foram compostas no Rio de Janeiro.

Segundo Peppercorn (1991, p.32), "seresta é na verdade uma serenata, um gênero musical para ser tocado durante a noite, ao ar livre".

Segundo Wright (1992, p.56), enquanto as Canções Típicas Brasileiras emprestam materiais e textos autênticos do folclore, as Serestas foram compostas de "uma maneira etnomusical oblíqua, na qual o compositor apara as arestas do material folclórico e utiliza a poesia de escritores brasileiros de sua época".

De acordo com o Museu Villa-Lobos, com dados confirmados por Appleby (1988, p.56), as primeiras audições dessas duas Serestas foram:

27.8.1940. Serenata, Alma Cunha de Miranda, canto.

15.8.1944. Voo, Maria Sylvia Pinto, canto; Francisco Mignone, piano.

\section{Serenata (Seresta nำ13)}

\section{Poesia}

David Nasser

Seresteiros cantando

Apaixonadas juras

Violões suplicando promessas de venturas...

A rua pequena subindo a colina 
Atraz da janela suspira a donzela...

A lua espreitando

Atraz da janela...

E a canção vem vindo de longe vem vindo de longe...

Pela estrada do céo, deserta e núa, envelhecida, (céu, nua)

O seu rosario vai rezando a lua (rosário)

Pelos que vivem sem amar na vida...

A bela flor da noite assiste muda o apelo de amôr que o violão traduz...

(amor)

Mas, companheiro,

A lua não te ajuda pois tira de teu sonho a sua luz...

Pela estrada do céo, deserta e nua, irmã das almas tristes, envelhecida,

o seu rosario vai rezando a lua pelos que sofrem por amar na vida... (rosário)

Ah!

\section{Estrutura formal e harmônica}

Seção A: Moderato: compassos 1 a 8, piano solo, abertura instrumental em dó menor, em estilo seresteiro e de inspiração violonística.

Seção B1: compassos 9 a 32, voz e piano.

Seção contrapontística entre a linha melódica do piano e a linha melódica da voz. A partir do compasso 15, a harmonia torna-se mais arrojada e um stringendo no compasso 27 traz de volta a tonalidade inicial e o material musical da introdução.

Seção A: compassos 31 a 38, piano solo, reprise de A, tonalidade estável de dó menor.

Seção B2: compassos 39 a 62, voz e piano, variante da seção B1. As linhas melódicas do piano e do canto concordam até o compasso 48. A partir de 49 a voz liberta-se da melodia do piano, e novamente a harmonia torna-se mais arrojada e cromática e um stringendo conduz mais uma vez à seção $A$.

Seção A: compassos 61 a 65, piano solo. Seção A mais curta, omitindo os compassos originais números 4, 5 e 6 . Tonalidade estável de dó menor que continua até o final da canção. 
Seção B3: Lento: compassos 66 a 80, voz e piano. Variante da seção B2. Comparar os compassos 66 a 69 de B3 aos compassos 39 a 42 de B2. Mesmo texto, mesma melodia: "pela estrada do céu, deserta e nua". No entanto, o diferencial de toda a seção é o acompanhamento do piano que desenvolve a seção A, superpondo-a aos elementos da seção B. Deste modo, tal procedimento consegue sintetizar todos os elementos musicais da canção. A partir do final do último tempo do compasso 69 a melodia desdobra-se em nova variação, direcionando-se para o Muito lento no compasso 74.

Os compassos 77 a 80 são a coda da canção.

\section{Aspectos interpretativos}

A seguir, sugerimos o emprego do pedal e do dedilhado que servirá de apoio ao pianista na execução da canção.

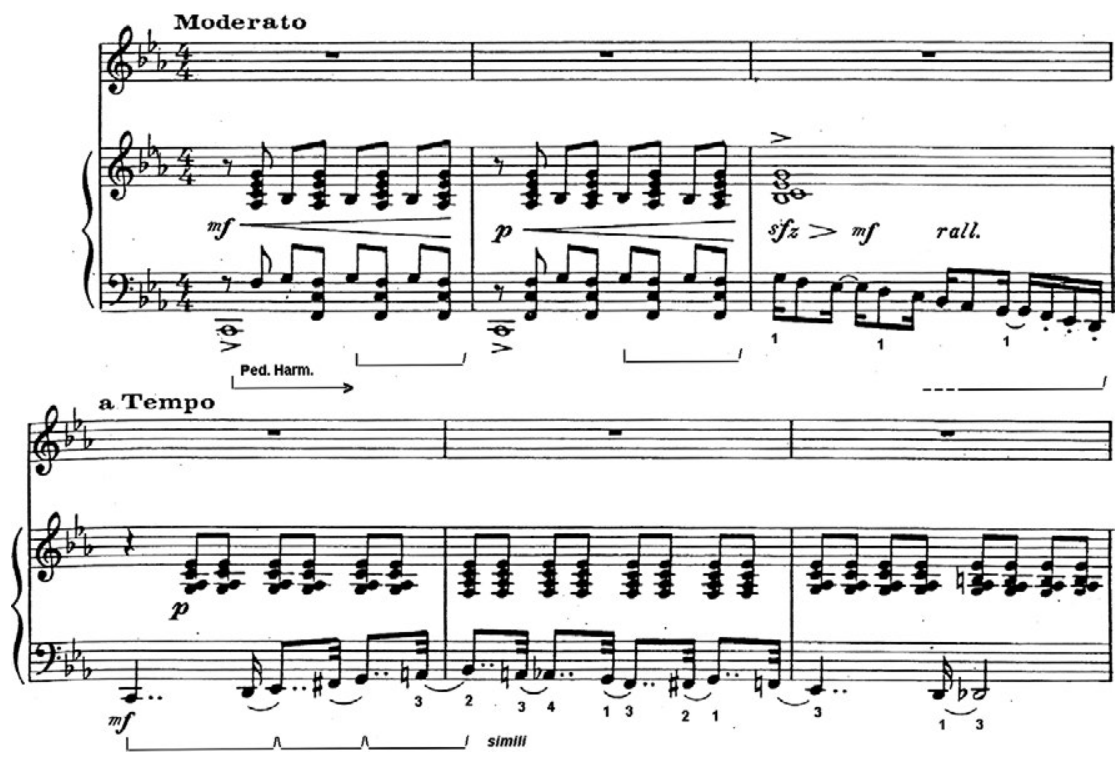

Villa-Lobos. Serenata, dedilhado e pedal, compassos 1-6.

Éditions Max Eschig, Paris, 1957. 


\section{Edição e manuscritos}

Três fontes de manuscritos viabilizaram um trabalho minucioso na revisão dessa canção. Um esboço doado pela família Guimarães ao Museu Villa-Lobos, um manuscrito no Museu Villa-Lobos e outro manuscrito, com a seresta transposta um tom abaixo, nos arquivos da Max Eschig, depositados na Biblioteca Nacional da França. A obra foi publicada originalmente em dó menor.

1. Nos dois manuscritos disponíveis não há a indicação de dinâmica $p$.

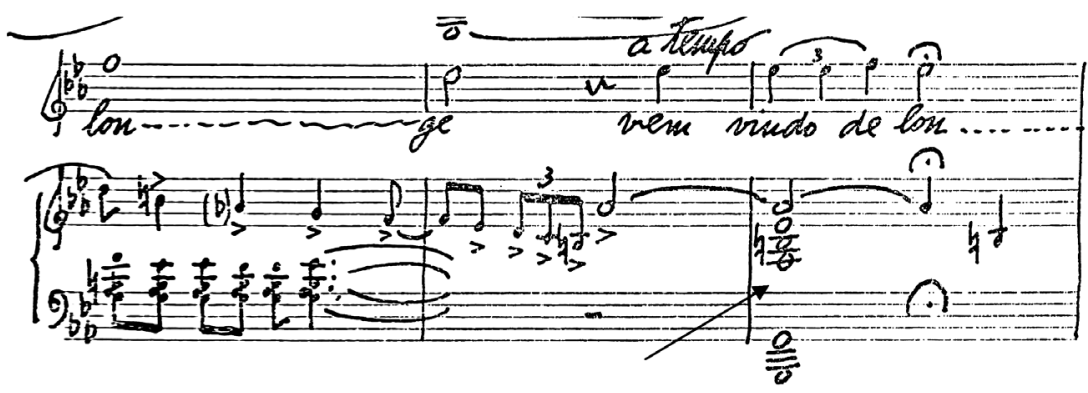

Villa-Lobos. Seresta nำ13, compassos 28-30.

Manuscrito, Museu Villa-Lobos, Rio de Janeiro.

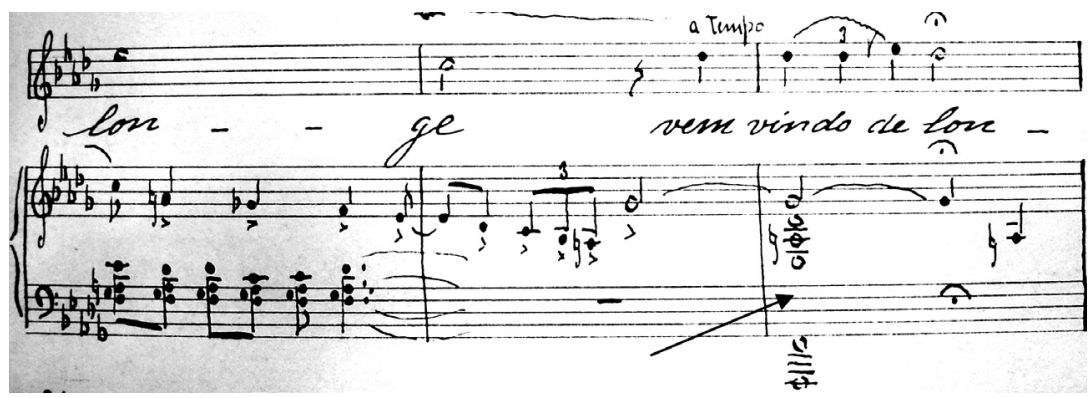

Villa-Lobos. Seresta nº13, compassos 28-30.

Manuscrito, Biblioteca Nacional da França, Paris. 


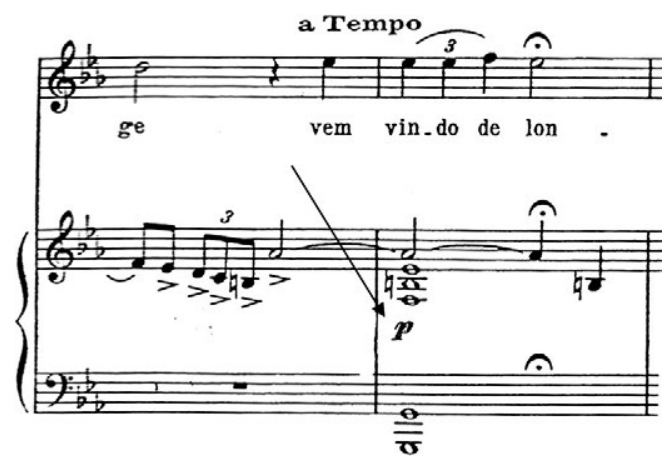

Villa-Lobos. Seresta nำ13, compassos 28-30. Éditions Max Eschig, Paris, 1957.

2. O acorde é uma repetição no manuscrito.
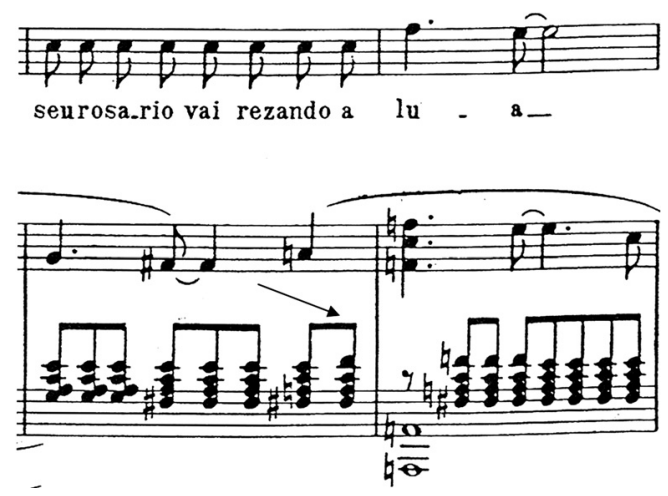

Villa-Lobos. Seresta nº13, compassos 44-5. Éditions Max Eschig, Paris, 1957.

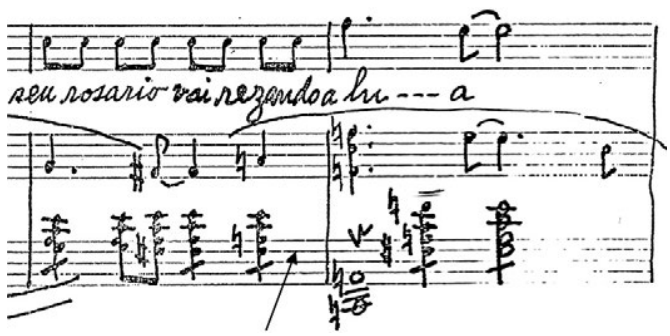

Villa-Lobos. Seresta n¹3, compassos 44-5.

Manuscrito, Museu Villa-Lobos, Rio de Janeiro. 


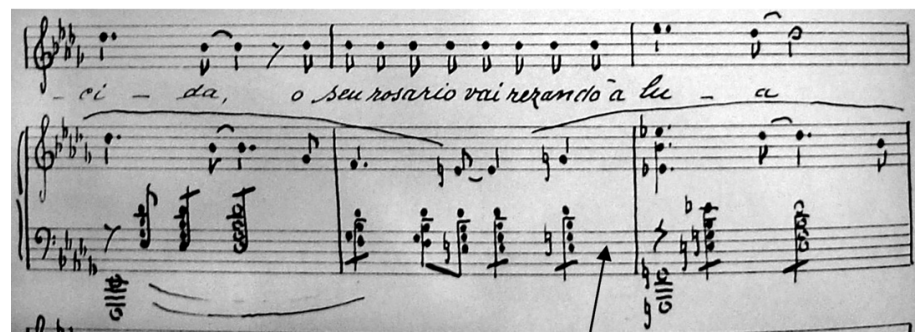

Villa-Lobos. Seresta nำ13, compassos 44-5. Manuscrito, Biblioteca Nacional da França, Paris.

3. De acordo com os manuscritos, o acorde é ré bemol - fá - si bemol - ré bemol e não ré bemol - fá - lá bemol - ré bemol.

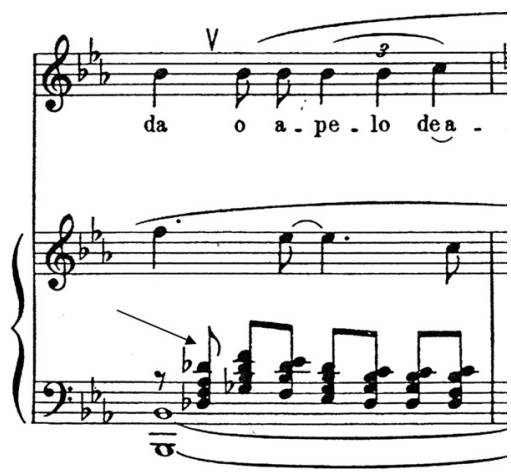

Villa-Lobos. Seresta nำ13, compasso 52. Éditions Max Eschig, Paris, 1957.

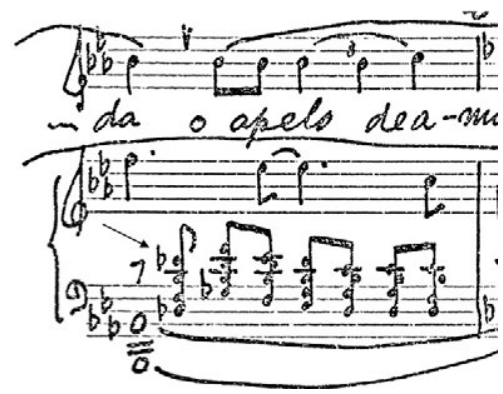

Villa-Lobos. Seresta nำ13, compasso 52.

Manuscrito, Museu Villa-Lobos, Rio de Janeiro. 


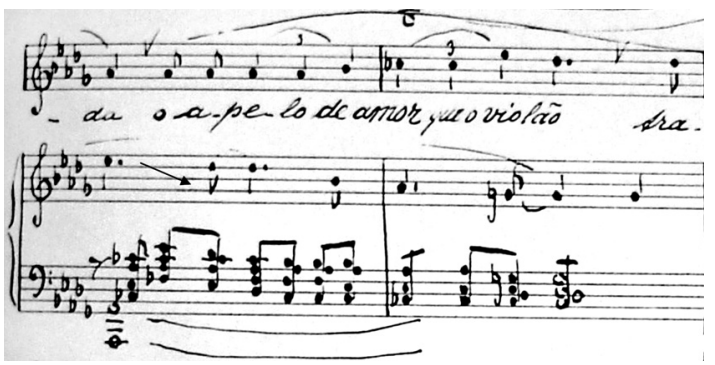

Villa-Lobos. Seresta nº̂13, compasso 52.

Manuscrito, Biblioteca Nacional da França, Paris.

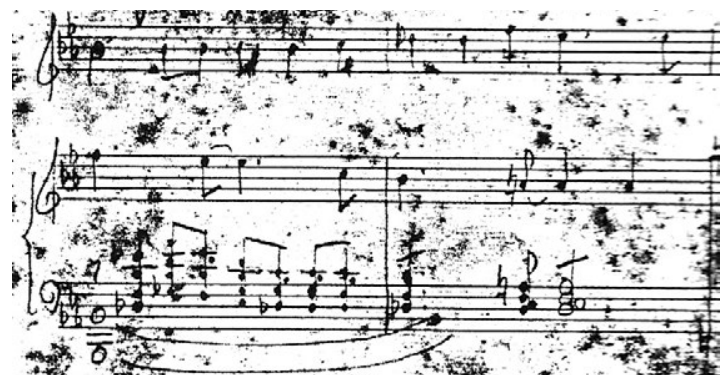

Villa-Lobos. Seresta n.13, compasso 52.

Esboço doado pela família Guimarães, Museu Villa-Lobos, Rio de Janeiro.

4. O acorde editado é fá - sol - si bemol - mi bemol. No manuscrito encontramos: fá - sol bemol - si bemol - mi bemol.

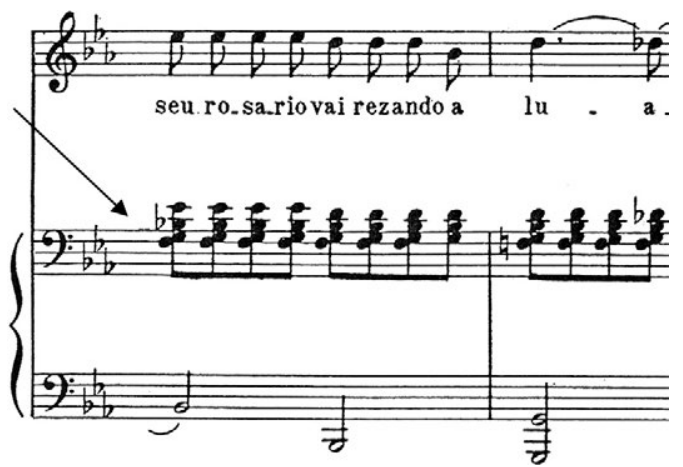

Villa-Lobos. Seresta nº13, compassos 73-4. Éditions Max Eschig, Paris, 1957. 


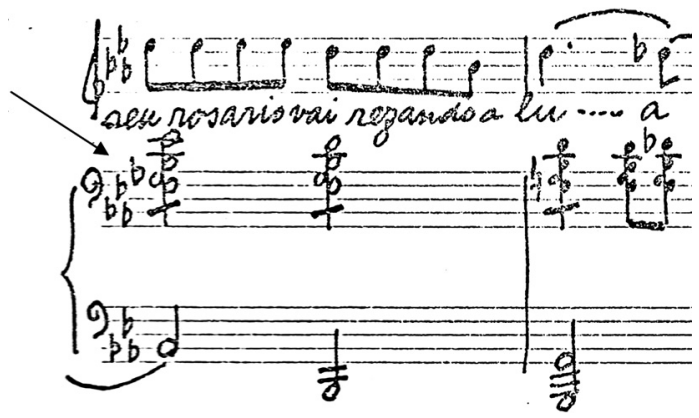

Villa-Lobos. Seresta nº13, compassos 73-4.

Manuscrito, Museu Villa-Lobos, Rio de Janeiro.

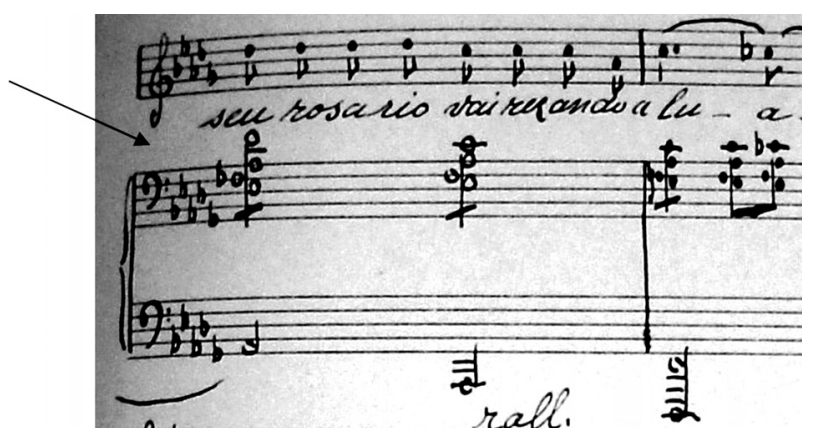

Villa-Lobos. Seresta nº13, compassos 73-4.

Manuscrito, Biblioteca Nacional da França, Paris.

\section{Voo (Seresta $\mathrm{n}$ 14)}

\section{Poesia}

Abgar Renault

Timida bolha, foi um céu no ar; (tímida)

frágil sorriso riu sob uns olhos;

freve palavra acendeu lumes e creou mundos; (criou) Ah!

Passaro azul, fendeu as nuvens, (pássaro) trouxe nas azas memorias de astros e de distâncias; 
agua de fonte, olhos lavou de muda insonia (insônia) matou a sêde a mãos febris e acêsa bôca; (sede, acesa, boca)

Agua de fonte que flue em vinho, (Água, flui) embebedou e alma bifronte e o corpo triste. Ah!

Breve palavra, fragil sorriso timida bolha; (frágil, tímida) surdo silencio no labio amargo, noite no olhar, (lábio) simples ar no ar.

Mas foi a vida.

Ah!

Ah!

Essa seresta é baseada em um texto dos mais abstratos de toda a série de Serestas. Villa-Lobos traduz o poema musicalmente por meio de uma canção que é um estudo em terças para o piano e um estudo cromático de virtuosidade para a voz. A volatilidade do voo é representada por uma linha etérea e flexível do piano e sempre desenvolvida em uma região médio-aguda.

\section{Estrutura formal e harmônica}

A técnica de composição de Villa-Lobos para essa canção aparece sistematizada nos estudos do maestro Duarte (2009, p.93-123): VillaLobos utiliza um método no qual a anatomia do pianista determina a linha melódica e os aspectos harmônicos da composição. Observar que o polegar geralmente toca as notas brancas e as terças são tocadas com os dedos mais longos geralmente com notas pretas e brancas, respeitando um design temático preestabelecido. Villa-Lobos cria desse modo uma espécie de politonalidade, que vem acompanhada por um cromatismo da linha melódica vocal.

A canção não tem armadura de clave, mas polariza a nota de mi b. A obra foi escrita em movimento perpétuo, elemento que empresta à obra uma grande unidade e coerência artística. Assim, não há divisões formais claras. A articulação das seções vem pela diversidade do fraseado.

Seção A1: Allegro: compassos 1 a 18.

Três compassos e meio introdutórios do piano sobre um arpejo de mi b. 
Treze compassos e meio acompanhando a voz.

Finalização da seção com o arpejo de mi b introduzido pelo piano.

Seção B1: compassos 19 a 30: seção composta por duas frases semelhantes.

Seção A2: compassos 31 a 46.

Finalização da seção com o arpejo de mi b, introduzido pelo piano.

Seção A3: compassos 47 a 63.

Finalização da seção com o arpejo de mi b introduzido pelo piano.

Coda: Vivo: compassos 64 a 74.

Desenvolvimento do arpejo que leva ao motivo que evoca um canto de pássaro. Uma nota repetida com uma appoggiatura, efeito muito utilizado em algumas obras de Villa-Lobos, como o canto do pássaro araponga no coral (Canto do sertão) da Bachianas Brasileiras no4 ou no Passarinho de pano da Prole do Bebê no2.

\section{Aspectos interpretativos}

A seguir, sugerimos dedilhados e empregos do pedal que servirão de base para a execução do pianista em toda a canção.
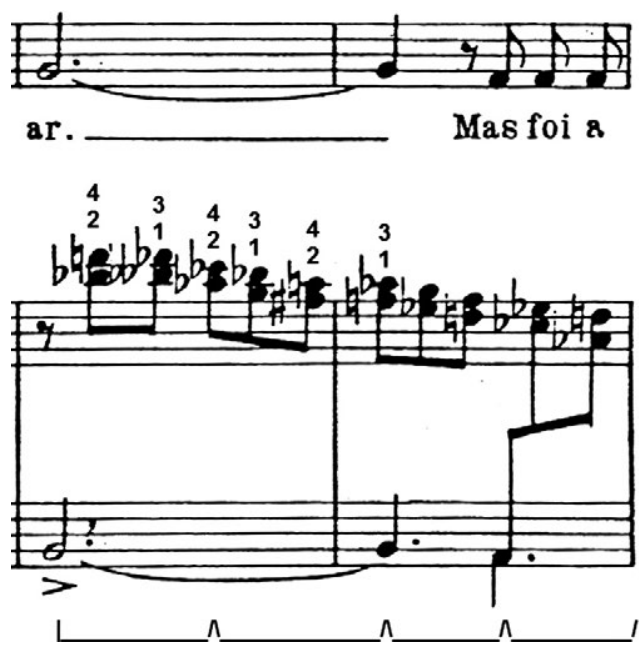

Villa-Lobos. Voo, dedilhado e pedal, compassos 59-60. Éditions Max Eschig, Paris, 1957. 

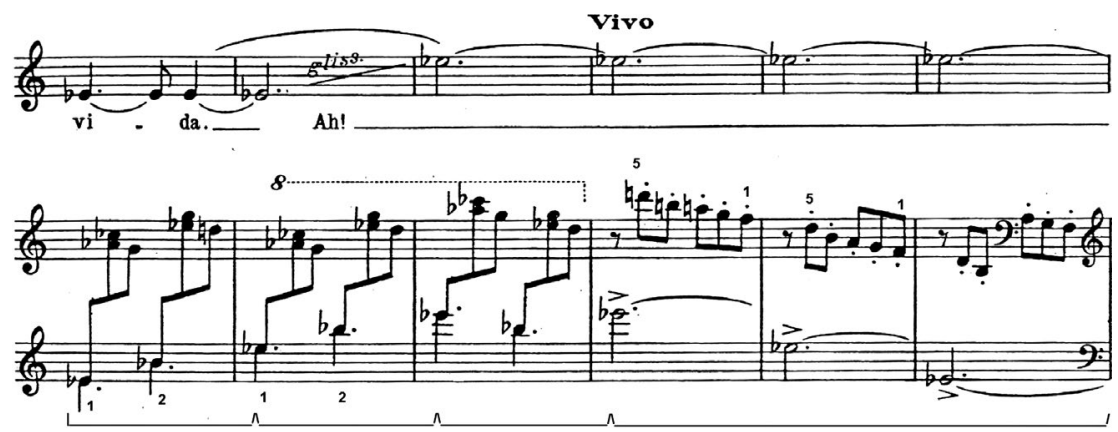

Villa-Lobos. Voo, dedilhado e pedal, compassos 61-6. Éditions Max Eschig, Paris, 1957.

\section{Edição e manuscrito}

O manuscrito da canção está desaparecido. Não consta nos arquivos do Museu Villa-Lobos e não consta nos arquivos das edições Max Eschig depositados na Biblioteca Nacional da França. A nota assinalada é, por analogia, provavelmente um ré bemol.

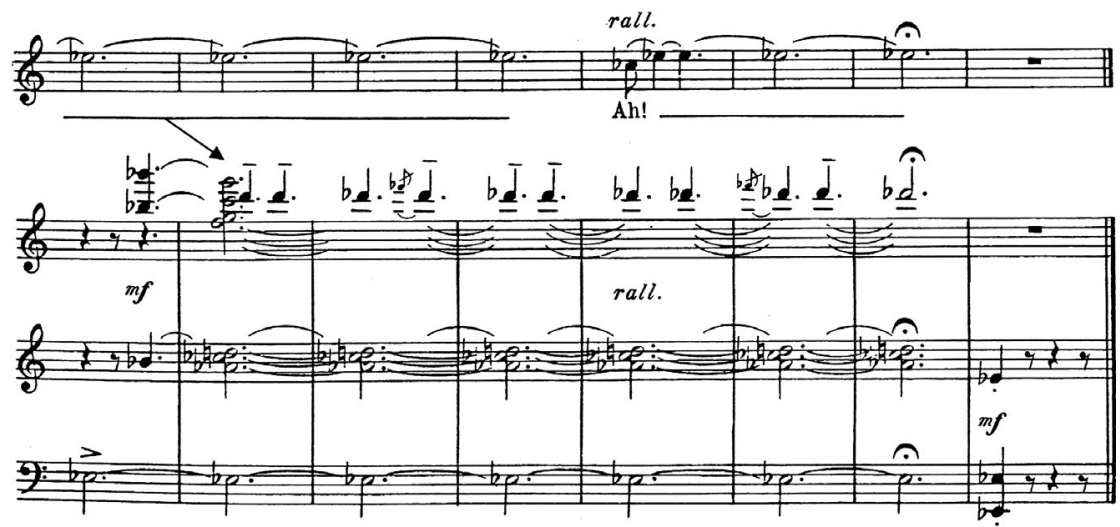

Villa-Lobos. Voo, compassos 67-74.

Éditions Max Eschig, Paris, 1957. 


\section{Deux Paysages}

Tabela 8. Deux Paysages, data da composição/publicação, gênero e texto

\begin{tabular}{|c|l|l|l|}
\hline Manhã na praia & 1946, 1957, Éditions Max Eschig & canção & poesia de Carlos Sá \\
\hline Tarde na Glória & 1946, 1957, Éditions Max Eschig & canção & poesia de Carlos Sá \\
\hline
\end{tabular}

As Duas Paisagens foram compostas no Rio de Janeiro e foram dedicadas a Cristina Maristany. De acordo com dados do Museu Villa-Lobos, confirmados por Appleby (1988, p.104), a primeira audição da obra foi realizada pela própria Cristina Maristany, em 1947, Rio de Janeiro, no estúdio da Rádio Tupi.

\section{Manhã na praia}

\section{Poesia}

\section{Carlos Sá}

Como um balão vermelho,

Que de invisiveis mãos se desprendesse invisíveis $\mathrm{E}$, ardendo numa chama inextinguivel inextinguível Subisse lento no ar, Nesta manhã de cinza e de fumaça, O sol sóbe no céo por sôbre o mar. sobe, céu, sobre

\section{Estrutura formal e harmônica}

As duas canções deste pequeno ciclo têm um estilo sóbrio, neoclássico, típico da última fase composicional de Villa-Lobos.

Na primeira canção, Manhã na praia, a tonalidade é somente delineada: lá menor. A melodia dessa canção sobe lenta e cromaticamente, "como um balão vermelho" que sobe lento no ar. A linha melódica tem seu ponto culminante nos compassos 13 e 14 .

\section{Aspectos interpretativos}

Os dedilhados e pedais a seguir podem servir de base para a execução da canção. 


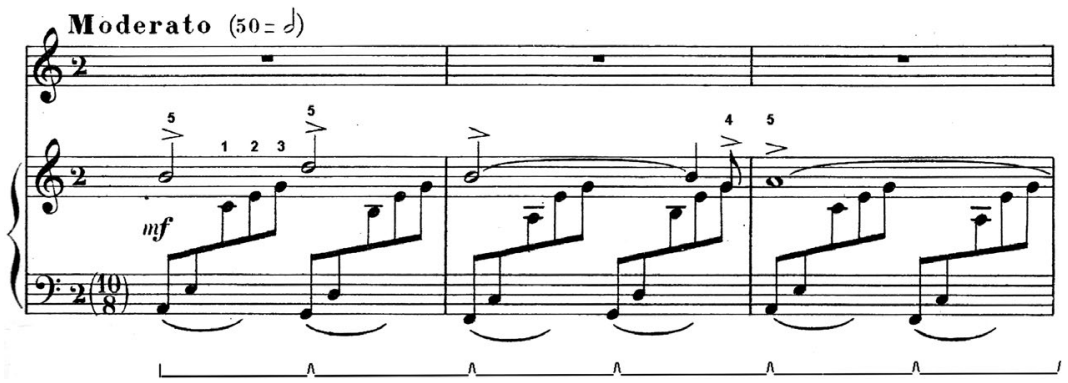

Villa-Lobos. Manhã na praia, dedilhados e pedal, introdução do piano. Éditions Max Eschig, Paris, 1957.
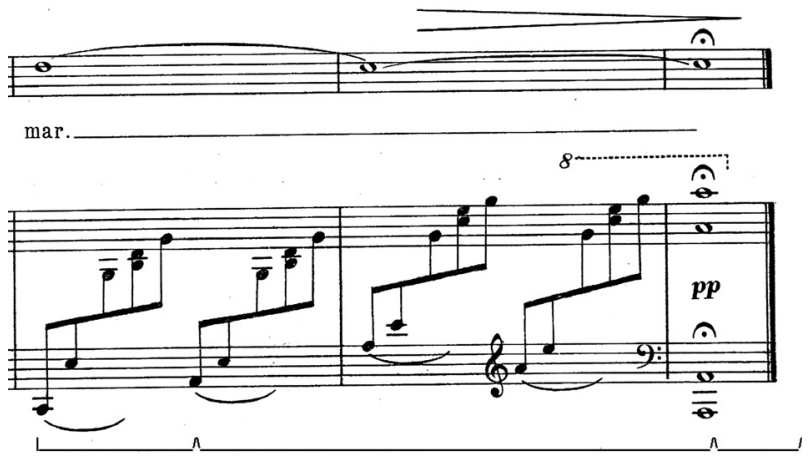

Villa-Lobos. Manhã na praia, pedal, compassos 18-9. Éditions Max Eschig, Paris, 1957.

\section{Edição e manuscritos}

1. Falta um ponto de aumento na mínima.

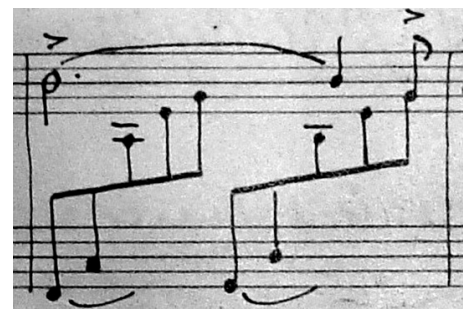

Villa-Lobos. Manhã na praia, compasso 2.

Manuscrito, Biblioteca Nacional da França, Paris. 


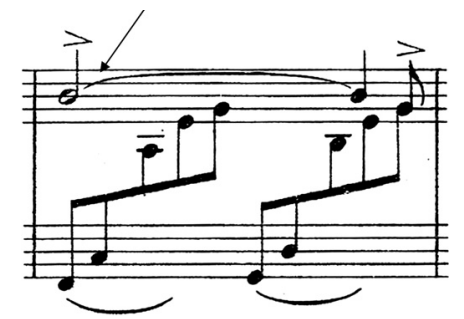

Villa-Lobos. Manhã na praia, compasso 2.

Éditions Max Eschig, Paris, 1957.

2. De acordo com o manuscrito, a nota correta é fá sustenido e não lá.

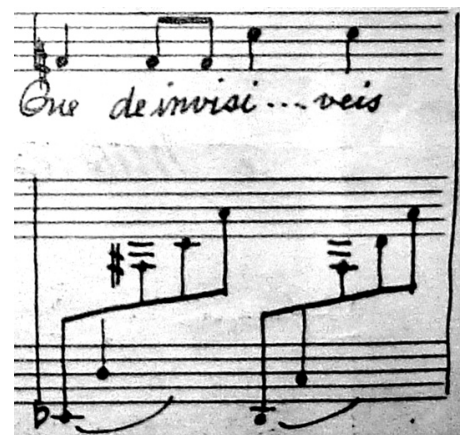

Villa-Lobos. Manhã na praia, compasso 6. Manuscrito, Biblioteca Nacional da França, Paris.
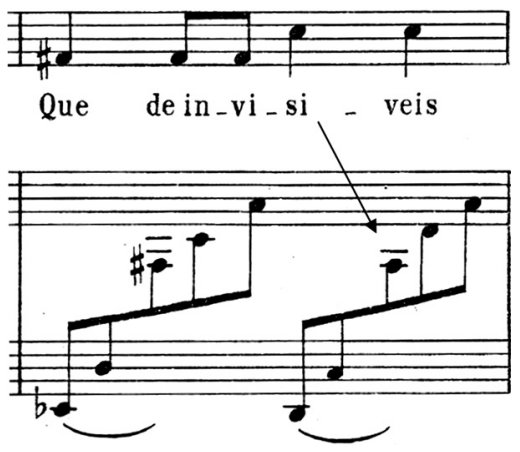

Villa-Lobos. Manhã na praia, compasso 6. Éditions Max Eschig, Paris, 1957. 


\section{Tarde na Glória}

\section{Poesia}

\section{Carlos Sá}

Na tarde clara, que empalidece,

Desponta, de repente, A floração radiosa da terra.

A beira do mar, sob as árvores

No alto das hastes de ferro forjado,

Os globos de cristal se enchem de luz.

\section{Estrutura formal e harmônica}

A canção está escrita em modo frígio.

Assim como a primeira canção, seu estilo é simples, sóbrio e neoclássico, sem nenhum arroubo nacionalista ou romântico. Há reflexos da rítmica de Igor Stravinsky.

Tema A: compassos 1 a 7 , piano solo.

Tema B: compassos 8 a 15, voz e piano.

Tema A: compassos 16 a 21, piano solo.

Tema C: compassos 22 a 30, voz e piano.

Coda: compassos 31 e 32, piano solo.

\section{Aspectos interpretativos}

Abaixo, sugerimos algumas possibilidades de pedal e dedilhado que poderão servir de base para a interpretação da canção.

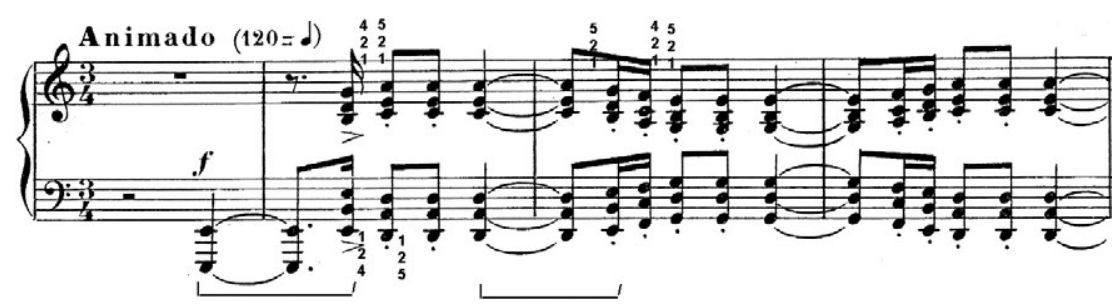

Villa-Lobos. Tarde na Glória, dedilhados e pedal, compassos 1-4. Éditions Max Eschig, Paris, 1957. 

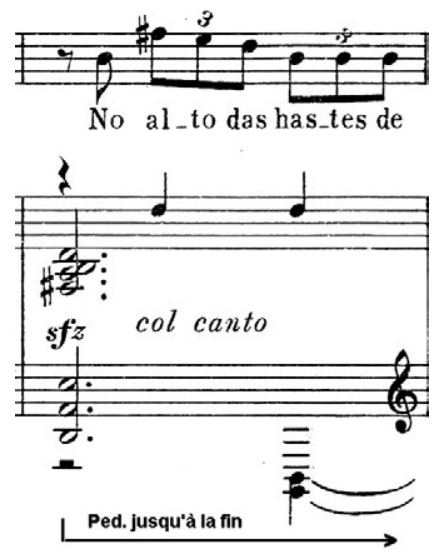

Villa-Lobos. Tarde na Glória, pedal, compasso 24.

Éditions Max Eschig, Paris, 1957.

\section{Edição e manuscritos}

Nesta canção não há erros de edição, mas sim uma omissão de notação que consta do manuscrito original.

Falta a indicação de sextinas para deixar clara sua notação para o intérprete.

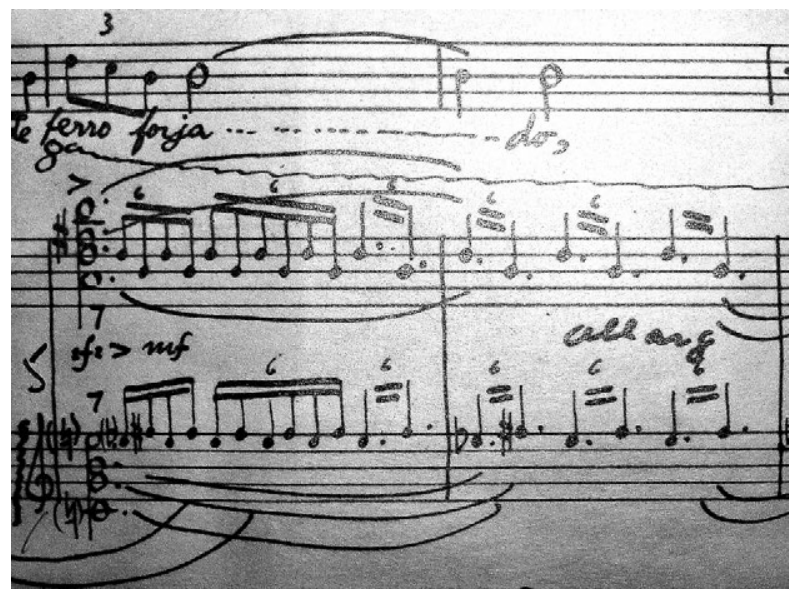

Villa-Lobos. Tarde na Glória, compassos 25-6.

Manuscrito, Biblioteca Nacional da França, Paris. 


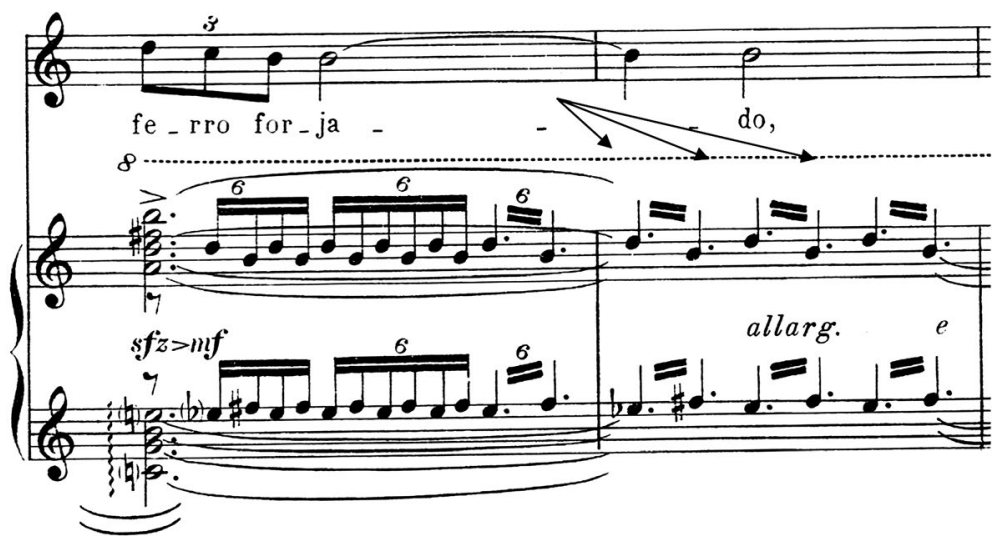

Villa-Lobos. Tarde na Glória, pedal, compassos 25-6.

Éditions Max Eschig, Paris, 1957. 


\section{ConCLUSÃo}

As canções escritas para voz e piano de Heitor Villa-Lobos, publicadas pela Max Eschig, oferecem ao intérprete, ao pesquisador, ao musicólogo e ao público em geral um painel bastante amplo e significativo do estilo do compositor. Todas as séries analisadas neste livro possuem uma grande diversidade estilística. Nessas coleções encontramos originais e transcrições de canções indígenas, cantos africanos, canções do anônimo popular, modinhas em estilo antigo, modinhas populares e até mesmo canções de forte conteúdo erudito e abstrato. Encontramos vários paradigmas dentro desses conjuntos de canções e suas semelhanças poderão contribuir para uma análise mais profunda do estilo vocal e instrumental do compositor.

A compreensão da estrutura formal e harmônica, aliada à análise paradigmática dos elementos composicionais e emocionais das canções, influenciou as soluções dos problemas musicológicos encontrados. Sugeriram-se algumas aplicações dos pedais ao piano, alguns dedilhados para facilitar o trabalho do pianista e também algumas possibilidades de fraseados para ambos os intérpretes, que poderão ser aplicados na performance desse repertório.

Nesse grupo de canções, encontraram-se 37 erros comprovados de edição, 16 prováveis erros e cerca de 11 divergências em versões diferentes da mesma canção. A maioria dos problemas encontrados 
nas partituras são erros da editora Max Eschig, portanto não são enganos cometidos pelo compositor. Nos manuscritos originais dessas coleções para canto e piano encontramos um compositor bastante preciso quanto à notação de suas ideias. Lamentavelmente, os erros presentes nas edições se perpetuaram na maioria dos registros pesquisados desse repertório. Assim, por meio dos resultados obtidos neste livro, esperamos colaborar para um melhor esclarecimento dos problemas existentes no texto musical impresso das canções de Heitor Villa-Lobos e seus futuros registros fonográficos.

Paris, maio de 2010 


\section{REFERÊNCIAS BIBLIOGRÁFICAS}

APPLEBY, D. P. Heitor Villa-Lobos, a Bio-Bibliography. Westport: Greenwood Press, 1988.

BASILE, G. La chanson au cinéma dans les années trente. In: PISTONE, D. (Org.) Musiques et musiciens à Paris dans les années trente. Paris: Honoré Champion Éditeur, 2000. p.241-56.

BEAUFILS, M. Villa-Lobos, musicien et poète du Brésil. Paris: Iheal, 1988 (reéd. 1967).

BURKHART, C. Anthology for musical analysis. Nova York: Harcourt Brace Jovanovich College Publishers, 2003.

COOPER, G., MEYER, L. The rhythmic structure of music. Chicago: The University of Chicago Press, 1960.

DUARTE, R. Villa-Lobos errou? Subsídios para uma revisão musicológica em Villa-Lobos. São Paulo: Algol, 2009.

EHRET, J. L'Effet de vie à l'ëcoute des oeuvres. In: JOURNEAU, V. A. (Dir.) Musique et effet de vie, Paris: L'Harmattan, 2009. p.13-33.

FLÉCHET, A. Villa-Lobos à Paris, un écho musical du Brésil. Paris: L'Harmattan, 2004.

FRANÇA, E. N. A evolução de Villa-Lobos na música de câmara. Rio de Janeiro: Museu Villa-Lobos, 1976.

JOURNEAU, V. A. (Dir.) Music et effet de vie. Paris: L'Harmattan, 2009.

GRENIER, M.-N. Présence du concerto pour piano dans la musique française des années trente. In: PISTONE, D. (Org.) Musiques et musiciens à Paris dans les années trente, p.289-98. Paris: Honoré Champion Éditeur, 2000. 
GUÉRIOS, P. R. Heitor Villa-Lobos e o ambiente artístico parisiense, convertendo-se em um músico brasileiro. In: Mana n.9, Abril, p.81108. Rio de Janeiro: Universidade Federal do Rio de Janeiro, 2003 a. Heitor Villa-Lobos: o caminho sinuoso da predestinação. Rio de Janeiro: Editora FGV, 2003b.

KIEFER, B. Villa-Lobos e o modernismo na música brasileira. Porto Alegre: Movimento, 1986.

KOELLREUTTER, H. J. Harmonia funcional. São Paulo: Ricordi, 1986. Terminologia de uma nova estética da música. Porto Alegre: Movimento, 1990.

KRIEGER, E. Heitor Villa-Lobos. In: Presença de Villa-Lobos VII. Rio de Janeiro: MEC/Museu Villa-Lobos. p.46.

MARIZ, V. A canção de câmara no Brasil. Porto: Livraria Progredior, 1948. Heitor Villa-Lobos. Belo Horizonte: Itatiaia, 1989.

MEEÙS, N. Logique et musique (1991). Analyse musicale 28 (1992). In: <http://www.plm.paris-sorbonne.fr/publications2Meeus.shtml>.

"Les rapports associatifs comme determinants du style", version revue (2006). Analyse musicale 32 (1993). In: <http://www.crlm.paris4. sorbonne.fr/Les\%20rapports\%20associatifs.pdf>.

MOTTE, D. de la. Armonía. Barcelona: Labor, 1989.

MÜNCH, M.-M. L'application de la théorie générale de l'effet de vie comme invariant universel à la musique. In: JOURNEAU, V. A. (Dir). Musique et effet de vie, p.13-33. Paris: L'Harmattan, 2009.

L'effet de vie ou le singulier de l'art. Paris: Champion, 2004.

NEVES, J. M. Música contemporânea brasileira. São Paulo: Ricordi Brasileira, 1981.

NICHOLS, R. The Harlequin years: Music in Paris 1917-1929. Londres: Thames \& Hudson, 2002.

NYEKI, M. Les hongrois et leur musique. In: PISTONE, D. (Org.) Musiques et musiciens à Paris dans les années trente. Paris: Honoré Champion Éditeur, 2000. p.533-45.

PEPPERCORN, L. M. Villa-Lobos. Rio de Janeiro: Ediouro, 1989.

Villa-Lobos, the music: an analysis of his style. Londres: Kahn \& Averill, 1991.

(Org.) The Villa-Lobos letters. Londres: Toccata Press, 1994.

PINTO DA SILVA ELIAS, M. H. Villa-Lobos, l'homme et son oeuvre pour le piano. Thèse de Doctorat, Université de Paris Sorbonne (Paris IV). Histoire de la Musique et Musicologie, 1984. Villeneuve d'Ascq: Presses Universitaires du Septentrion, 1995. 
PISTONE, D. Les conditions historiques de l'exotisme musical français. Revue Internationale de Musique Française, p.11-22. $2^{\text {ème }}$ année. Genebra, Paris: Slatkine, Nov. 1981.

. (Org). Musiques et musiciens à Paris dans les années trente. Paris: Honoré Champion Éditeur, 2000.

Matériaux, structure et vie musicale. In: JOURNEAU, V. A. (Dir). Musique et effet de vie, p.13-33. Paris: L'Harmattan, 2009.

PORCILE, F. La Belle Époque de la musique française: le temps de Maurice Ravel (1871-1940). Paris: Fayard, 1999.

ROTHSTEIN, W. Phrase rhythm in tonal music. Nova York: Schirmer Books, 1989.

SCHACHTER, C., ALDWELL, E. Harmony and voice leading. Nova York: Harcourt Brace Jovanovich College Publishers, 1989.

SEGONZAC, C. D. de. Marguerite Long (1874-1966): un siècle de vie musicale française. Paris: Findakly, 1993.

SCHENKER, H. Harmony. Chicago: The University of Chicago Press, 1954.

Five graphic music analyses. Nova York: Dover Books, 1969.

SCHIC, A. S. Villa-Lobos, souvenirs de l'indien blanc. Paris: Actes Sud, 1987.

SCHOENBERG, A. Theory of harmony. Boston: Faber and Faber, 1911 (reprint 1986).

. Funções estruturais da harmonia. Tradução de Eduardo Seincman. São Paulo: Via-Lettera, 2004.

SIMÕES, D. Estudos semânticos n.7. Rio de Janeiro: UERJ, 2003.

TARASTI, E. Villa-Lobos: the life and works 1887-1959. Jefferson, North Carolina: McFarland \& Company, 1995.

WRIGHT, S. Villa-Lobos. Nova York: Oxford University Press, 1992. 


\author{
SOBRE O LIVRO \\ Formato: $14 \times 21 \mathrm{~cm}$ \\ Mancha: 23,7 x 42,5 paicas \\ Tipologia: Horley Old Style 10,5/14 \\ 1a edição: 2010 \\ EQUIPE DE REALIZAÇÃO \\ Coordenação Geral \\ Marcos Keith Takahashi
}



